ALONSO ANTONIO LÓPEZ SILVA

RECUPERAÇÃO DE CORTIÇOS NA ÁREA CENTRAL DA CIDADE DE SÃO PAULO

SÃO PAULO

2011 
ALONSO ANTONIO LÓPEZ SILVA

\section{RECUPERAÇÃO DE CORTIÇOS NA ÁREA CENTRAL DA CIDADE DE SÃO PAULO}

Dissertação apresentada à Escola Politécnica da Universidade de São Paulo para obtenção de título de Mestre em Engenharia.

SÃO PAULO 
ALONSO ANTONIO LÓPEZ SILVA

\title{
RECUPERAÇÃO DE CORTIÇOS NA ÁREA CENTRAL DA CIDADE DE SÃO PAULO
}

\author{
Dissertação apresentada à Escola \\ Politécnica da Universidade de São Paulo \\ para obtenção de título de Mestre em \\ Engenharia.
}

Área de Concentração:

Engenharia de Construção Civil e Urbana.

Orientador:

Prof. Dr. Alex Kenya Abiko

São Paulo 
Este exemplar foi revisado e alterado em relação à versão original, sob responsabilidade única do autor e com a anuência de seu orientador.

São Paulo, 29 de setembro de 2011.

Assinatura do autor

Assinatura do orientador

FICHA CATALOGRÁFICA

López Silva, Alonso Antonio

Recuperação de cortiços na área central da cidade de São

Paulo I A.A. López Silva. - ed.rev. -- São Paulo, 2011.

$220 \mathrm{p}$.

Dissertação (Mestrado) - Escola Politécnica da Universidade de São Paulo. Departamento de Engenharia de Construção Civil.

1. Cortiços (Recuperação) - São Paulo (SP) 2. Habitação 3. Qualidade de vida I. Universidade de São Paulo. Escola Politécnica. Departamento de Engenharia de Construção Civil II. t. 
Dedico este trabalho aos moradores de cortiços do centro da cidade de São Paulo, que representam os paulistanos, natos ou não, que, desde fins do século XIX, no descanso dos justos em habitações precárias, ao fim de árduas jornadas, construíram e desenvolveram, com seus hábitos, costumes, traços culturais e religiosos - em pouco mais de um século - esta cidade, compondo, em minha opinião, o principal capital paulistano: a diversidade étnica, econômica e social. 


\section{AGRADECIMENTOS}

Como diretor da Divisão Técnica Regional de Atendimento Habitacional - Habi-Centro -, da Superintendência de Habitação Popular, da Secretaria Municipal de Habitação da cidade de São Paulo, responsável, desde fevereiro de 2005, pelo atendimento habitacional a famílias de baixa renda no território das subprefeituras Sé, Mooca, Lapa e Pinheiros, agradeço, especialmente, à minha amiga e chefe, neste período, Dra. Elisabete França, Secretária Adjunta de Habitação do Município de São Paulo e Superintendente de Habitação Popular, pela oportunidade e confiança em mim depositada no desempenho dessa tarefa de tamanha responsabilidade, e também pela motivação para iniciar uma dissertação de mestrado sobre o tema cortiços, propiciando a discussão em esfera acadêmica e a disseminação de importantes dados obtidos ao longo de cinco anos de trabalho. Da mesma forma, agradeço à equipe de Habi-Centro, que, desde o início dos trabalhos do Programa de Cortiços, abordou o tema com responsabilidade e dedicação. Entre eles agradeço a Beatriz Malhmeister, Daniel Kalil, Júlio César Delgado, Keli Cristina Anacleto, Luiz Fernando Arias Fachini, Maria José Brandão Calderini, Marilia Arsani, Nancy Cavallete, Ricardo Rodrigues e Sonia Auletta.

Aos colegas Aderbal José Curvelo do Banco Interamericano de Desenvolvimento e a equipe da Cities Alliance, Tereza Herling, Eliene Correia Rodrigues Coelho e especialmente a Thomas Hagenbrock cuja breve participação no desenvolvimento do programa de cortiços teve fundamental importância em sua concepção. 
Especialmente, agradeço à minha amiga Violeta Saldanha Kubrusly pelo apoio sempre alentador e da mesma forma ao meu amigo André Gutierrez.

Agradeço aos secretários municipais de habitação Dr. Orlando Almeida, Dr. Elton Santa Fé Zacarias, Dr. Ricardo Pereira Leite e Dr. Lair Krähenbühl - secretário de habitação do governo estadual, que apoiaram o Programa de Cortiços quando ainda era um projeto a ser implementado.

Aos subprefeitos Eduardo Odloak, Amauri Pastorelo, Cel Nevoral Alves Bucheroni, Cel. Rubens Casado e aos amigos Ricardo Thomaz, Joceli Silva, sem os quais o Programa não teria desenvolvimento.

Aos colegas Sergio Raul Camaranno, Reinaldo lapequino, Mariliza Targa Fernandes, Maria Claudia da Costa Brandão, Sonia Elisabeth Martins e Silvio Bruno Boinel da Companhia de Desenvolvimento Habitacional e Urbano (CDHU) pela parceria impecável nos dois programas de cortiços.

Às assistentes sociais Maria Inês D'Alessio Reis, Ana Maria Artigas Roca, Lory Siqueira, Martha Braga Escaleira da Silva, Renata Bernardo de Souza Capecci, lara Eugênia Batista, Renata Barbosa dos Santos, Rosana de Fátima Dias Jobbagy e aos arquitetos Bruno Pietro Contabile e Cosme Souza Silva da gerenciadora social Diagonal Urbana pela motivação e desenvolvimento em campo dos trabalhos sociais.

Aos professores doutores Witold Zmitrowicz e Andrea Piccini que elaboraram comentários de extrema importância. $E$ finalmente, agradeço ao professor doutor Alex Kenya Abiko que orientou o desenvolvimento deste trabalho. 


\section{RESUMO}

O governo municipal de São Paulo elaborou um programa para recuperar aproximadamente 1.000 cortiços destinados ao aluguel de cômodos para a população de baixa renda na região central. Tais imóveis caracterizam-se pelas más condições de habitabilidade decorrentes da superlotação de pessoas e da degradação geral dos ambientes internos que ocorrem no âmbito de uma negociação informal da locação residencial. Esta dissertação relata as atividades desenvolvidas pelo poder público no período de 2005 a 2010, que promoveram melhorias na qualidade de vida de moradores de cortiços através da fiscalização das condições de habitabilidade desses imóveis. Outrossim, analisa a aplicação da legislação que rege tais iniciativas, apresentando recomendações de revisão dessa legislação, como meio de contribuição para o aperfeiçoamento dos instrumentos de recuperação dessas habitações precárias.

Palavras-chave: Ambiente. Interno. Baixa renda. Sustentável. Edificações. Superlotação. Cortiços. São Paulo. 


\title{
RENOVATIONS ON OVERCRAWDED HOUSES IN DOWN TOWN SÃO PAULO
}

\begin{abstract}
The city hall of São Paulo plans the renovation of 1,000 "cortiços" (literally translated: "beehive"; overcrowded, decaying and precarious tenements), occupied for low-income families in the inner-city área. These tenements are characterized by low living conditions caused by the general decay of interior spaces and overcrowding through informal subletting. The present dissertation relates the methodology (developed by the municipal administration between 2005 and 2010) used to achieve substantial improvement to the residents quality of life. Moreover, this dissertation reviews applicable law and recommends its revision in order to develop improved legal instruments for upgrading this substandard housing.
\end{abstract}

Keywords: Indoor. Environmental. Low-income. Sustainable. Building. Overcrowded. São Paulo. Tenement. 


\section{LISTA DE GRÁFICOS}

Gráfico 1 - Análise Gerencial do Programa .............................................. 92

Gráfico 2 - Classificação dos Imóveis Vistoriados ................................... 93

Gráfico 3 - Análise Gerencial dos Cortiços ................................................ 95

Gráfico 4 - Distribuição dos Cortiços por Distrito de Subprefeitura.................. 96

Gráfico 5 - Vistorias Efetuadas por Mês ................................................. 97

Gráfico 6 - Porte de Reforma dos Cortiços Vistoriados ............................... 98

Gráfico 7 - Índices de Adequação das Vistorias Prévias .............................. 99

Gráfico 8 - Caracterização dos Lotes - Tipologia da Edificação ................... 101

Gráfico 9 - Caracterização dos Lotes - Testada .................................... 102

Gráfico 10 - Caracterização dos Lotes - Profundidade ............................. 103

Gráfico 11 - Caracterização dos Lotes - Área do Terreno ............................ 104

Gráfico 12 - Caracterização dos Lotes - Área Construída ........................... 105

Gráfico 13 - Dados Cadastrais dos Imóveis - Ano de Construção................ 106

Gráfico 14 - Dados Cadastrais dos Imóveis - Valor por Metro Quadrado..... 107

Gráfico 15 - Análise do Trabalho Social - Geral.................................... 110

Gráfico 16 - Análise do Trabalho Social - Acompanhamento ...................... 111

Gráfico 17 - Análise do Trabalho Social - Atendimentos e Benefícios

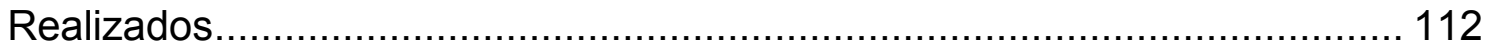

Gráfico 18 - Salubridade - Ventilação .................................................. 115

Gráfico 19 - Salubridade - Iluminação .................................................. 116

Gráfico 20 - Salubridade - Área Mínima ................................................. 117

Gráfico 21 - Salubridade - Adensamento Máximo .................................. 118

Gráfico 22 - Salubridade - Revestimento dos Sanitários ........................... 119

Gráfico 23 - Salubridade - Pé-Direito Mínimo ........................................ 120

Gráfico 24 - Salubridade - Circulação ............................................. 121

Gráfico 25 - Salubridade - Sinais de Infiltração......................................... 122

Gráfico 26 - Salubridade - Rede de Água ............................................... 123

Gráfico 27 - Salubridade - Rede de Esgoto ....................................... 124

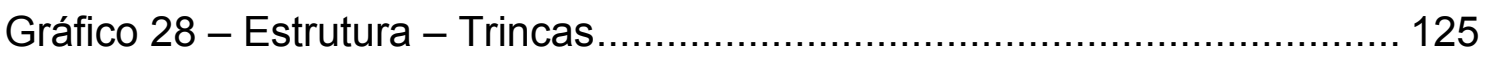


Gráfico 29 - Estrutura - Armaduras Expostas ................................... 126

Gráfico 30 - Estrutura - Forro ........................................................ 127

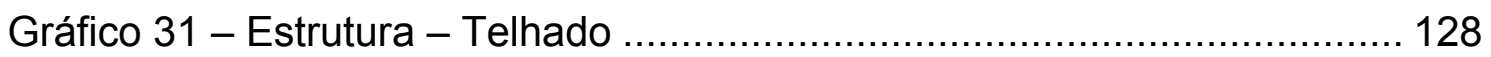

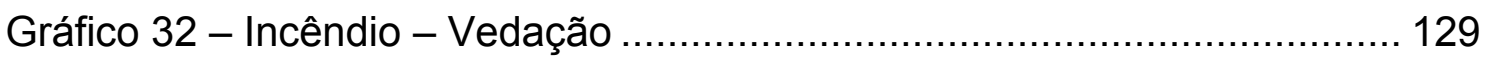

Gráfico 33 - Incêndio - Material Inflamável ...................................... 130

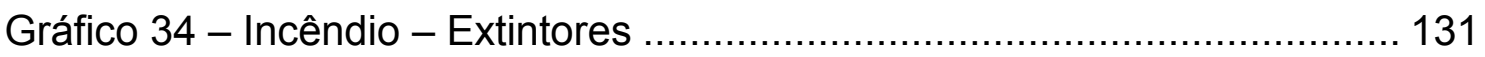

Gráfico 35 - Incêndio - Localização dos Botijões ...................................... 132

Gráfico 36 - Incêndio - Rede Elétrica Interna......................................... 133

Gráfico 37 - Incêndio - Quadro de Luz................................................ 134

Gráfico 38 - Incêndio - Tomadas ...................................................... 135

Gráfico 39 - Sistemas - Eletropaulo ........................................... 136

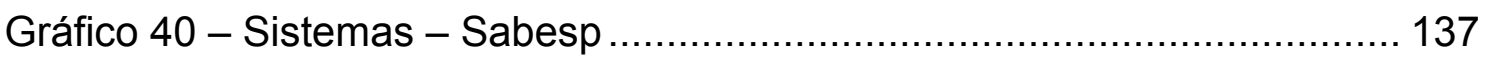

Gráfico 41 - Índices de Adequação das Visitas mais recentes ..................... 139

Gráfico 42 - Progresso dos Índices de Adequação ................................... 140 


\section{LISTA DE TABELAS}

Tabela 1 - Evolução da população. Simões Junior, 1991 ........................... 15

Tabela 2 - Resultados do Quadro Lógico do Programa de Cortiços ............... 60

Tabela 3 - Atividades do Quadro Lógico do Programa de Cortiços ................. 61

Tabela 4 - Dados gerais do imóvel encortiçado....................................... 67

Tabela 6 - Dados levantados referentes à Lei Moura ...................................68

Tabela 8 - Dados socioeconômicos do arrolamento das famílias...................69 69

Tabela 10 - Pesos dos grupos de itens do Sistema de Informações (Habisp) 78

Tabela 12 - Peso dos atributos gerais levantados nos imóveis encortiçados.. 79

Tabela 14 - Dados gerais do Programa de Cortiços.................................. 90

Tabela 15 - Dados Relevantes dos Cortiços ......................................... 91

Tabela 16 - Análise Gerencial do Programa .......................................... 91

Tabela 17 - Classificação dos Imóveis Vistoriados...................................... 93

Tabela 18 - Análise Gerencial dos Cortiços.................................................. 94

Tabela 19 - Distribuição dos Cortiços por Distrito de Subprefeitura ................ 96

Tabela 20 - Porte de obra dos cortiços vistoriados................................. 98

Tabela 21 - Índices de Adequação das Vistorias Prévias ............................. 99

Tabela 22 - Caracterização dos Lotes - Tipologia da Edificação .................. 101

Tabela 23 - Caracterização dos Lotes - Testada ................................... 102

Tabela 24 - Caracterização dos Lotes - Profundidade................................ 103

Tabela 25 - Caracterização dos Lotes - Área do Terreno............................. 104

Tabela 26 - Caracterização dos Lotes - Área Construída ........................... 105

Tabela 27 - Dados Cadastrais dos Imóveis - Ano de Construção ................ 106

Tabela 28 - Dados Cadastrais dos Imóveis - Valor por Metro Quadrado ...... 107

Tabela 29 - Análise do Trabalho Social - Geral ..................................... 109

Tabela 30 - Análise do Trabalho Social - Acompanhamento ...................... 110

Tabela 31 - Análise do Trabalho Social - Atendimentos e Benefícios Realizados...................................................................................... 112

Tabela 32 - Caracterização dos Imóveis - Salubridade - Ventilação............ 115

Tabela 33 - Caracterização dos Imóveis - Salubridade - Iluminação ............ 116 
Tabela 34 - Caracterização dos Imóveis - Salubridade - Área Mínima.

Tabela 35 - Caracterização dos Imóveis - Salubridade - Adensamento Máximo 118

Tabela 36 - Caracterização dos Imóveis - Salubridade - Revestimento dos Sanitários 119

Tabela 37 - Caracterização dos Imóveis - Salubridade - Pé-Direito Mínimo 120

Tabela 38 - Caracterização dos Imóveis - Salubridade - Circulação 121

Tabela 39 - Caracterização dos Imóveis - Salubridade - Sinais de Infiltração122

Tabela 40 - Caracterização dos Imóveis - Salubridade - Rede de Água ..... 123

Tabela 41 - Caracterização dos Imóveis - Salubridade - Rede de Esgoto... 124

Tabela 42 - Caracterização dos Imóveis - Estrutura - Trincas 125

Tabela 43 - Caracterização dos Imóveis - Estrutura - Armaduras Expostas 126

Tabela 44 - Caracterização dos Imóveis - Estrutura - Forro 127

Tabela 45 - Caracterização dos Imóveis - Estrutura - Telhado 128

Tabela 46 - Caracterização dos Imóveis - Incêndio - Vedação. 129

Tabela 47 - Caracterização dos Imóveis - Incêndio - Material Inflamável .... 130

Tabela 48 - Caracterização dos Imóveis - Incêndio - Extintores 131

Tabela 49 - Caracterização dos Imóveis - Incêndio - Localização dos Botijões 132

Tabela 50 - Caracterização dos Imóveis - Incêndio - Rede Elétrica Interna 133

Tabela 51 - Caracterização dos Imóveis - Incêndio - Quadro de Luz .......... 134

Tabela 52 - Caracterização dos Imóveis - Incêndio - Tomadas ................... 135

Tabela 53 - Caracterização dos Imóveis - Sistemas - Eletropaulo............... 136

Tabela 54 - Caracterização dos Imóveis - Sistemas - Sabesp.................... 137

Tabela 55 - Índices de Adequação das Visitas mais recentes...................... 139

Tabela 56 - Progresso dos Índices de Adequação ................................... 140

Tabela 57 - Quadro de subsídios para alteração da Lei Moura..................... 145

Tabela 58 - Proposta de alteração da Lei Moura...................................... 147 


\section{SUMÁRIO}

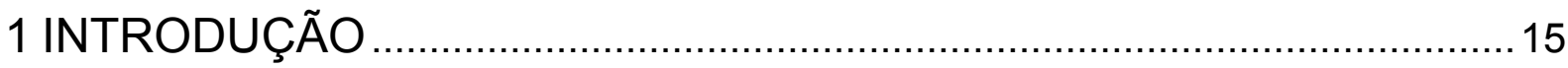

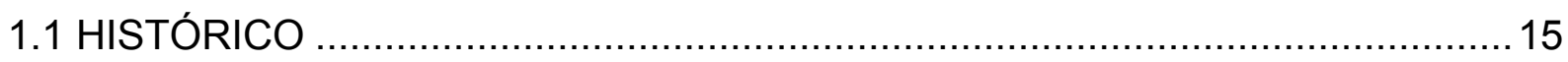

1.2 HISTÓRICO DA LEGISLAÇÃO INCIDENTE AO LONGO DO SÉCULO XIX

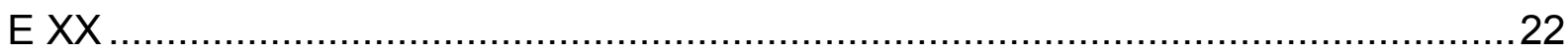

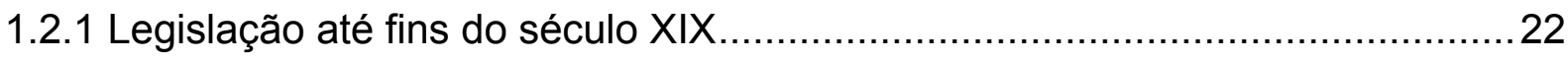

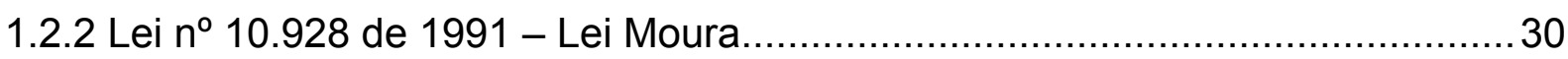

1.2.3 Lei Federal $n^{\circ} 8.245$ de 1991 - Lei do Inquilinato ......................................... 34

1.2.4 Lei no 11.228 de 1992 - Código de Obras e Edificações do Município de

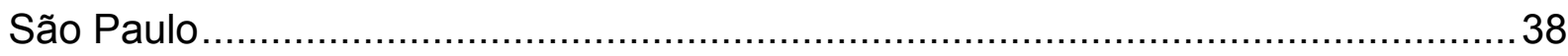

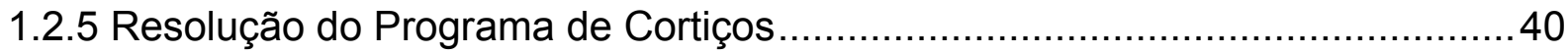

1.2.6 O Plano Municipal de Habitação de São Paulo e a Moradia Digna................... 42

1.3 FUNÇÃO SOCIAL DA PROPRIEDADE E SUSTENTABILIDADE URBANA.......46

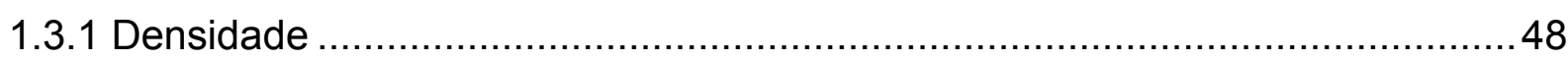

1.3.2 Vacância no mercado residencial formal na área central de São Paulo ..........51

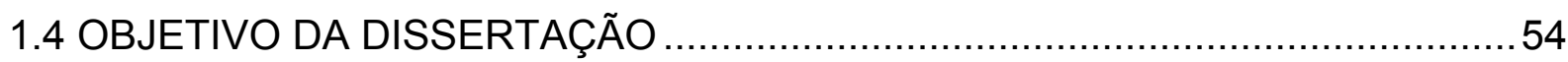

2 RELATO DAS ATIVIDADES DO PROGRAMA DE CORTIÇOS DA PREFEITURA DO MUNICÍPIO DE SÃO PAULO ........................................57

2.1 OBJETIVO DO PROGRAMA DE CORTIÇOS - QUADRO LÓGICO DO

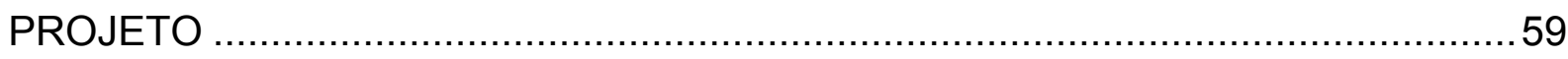

2.2 PROGRAMA EM LARGA ESCALA E LEVANTAMENTO DOS IMÓVEIS

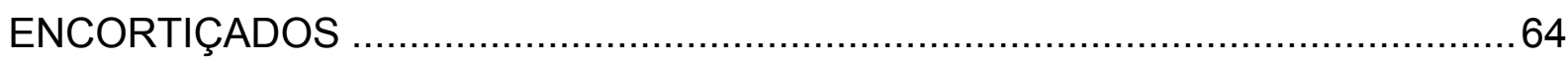

2.3 OS PRIMEIROS IMÓVEIS INTIMADOS E VISTORIADOS ................................70

2.4 REVISÃO DE PLANEJAMENTO E RECOMENDAÇÃO DE OBRA …................72

2.5 ASPECTOS DA FISCALIZAÇÃO E PERENIDADE DA AÇÃO

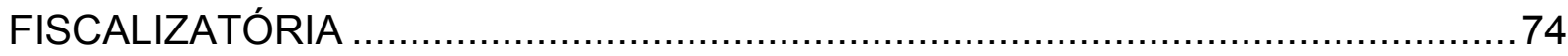

2.6 SISTEMA DE PRIORIZAÇÃO DA SUPERINTENDÊNCIA DE HABITAÇÃO POPULAR DA SECRETARIA MUNICIPAL DE HABITAÇÃO (HABISP) ...................77

2.7 FLUXOGRAMA DO PROGRAMA DE CORTIÇOS ............................................. 80

3 RESULTADOS DO PROGRAMA DE CORTIÇOS .................................. 89 
3.1 DADOS GERAIS DO PROGRAMA DE CORTIÇOS …..................................90

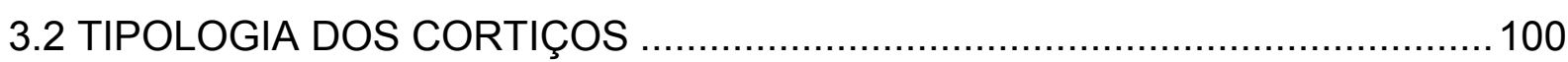

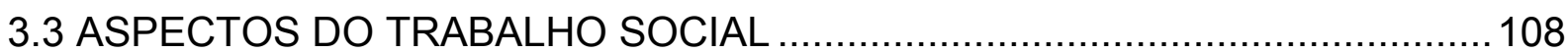

3.4 ASPECTOS DA DEGRADAÇÃO EM CORTIÇOS …..................................113

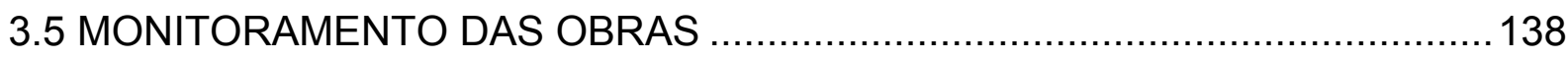

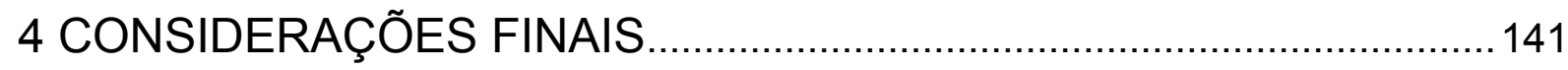

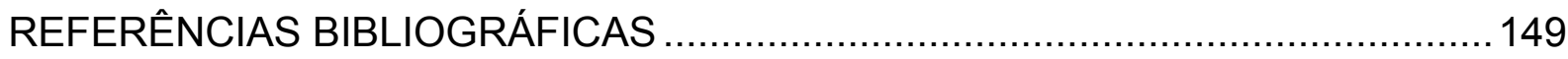

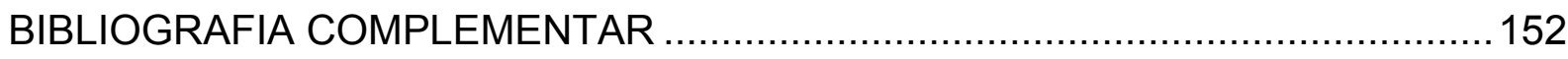

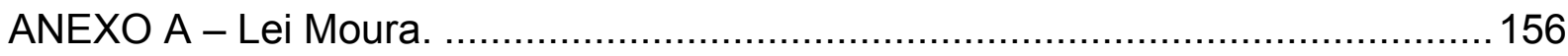

ANEXO B - Decreto que regulamenta a Lei Moura. .........................................160

ANEXO C - Resolução do Programa de Cortiços do Conselho Municipal de

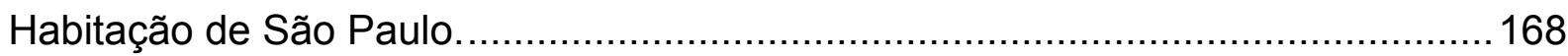

ANEXO D - Fotografias realizadas em "Vistorias Prévias" de imóveis

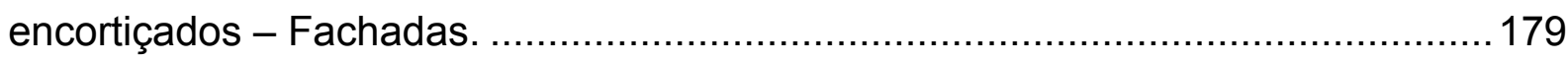

ANEXO E - Fotografias realizadas em "Vistorias Prévias" de imóveis

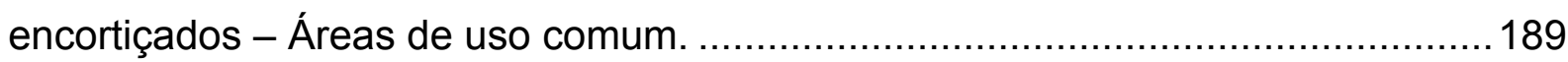

ANEXO F - Fotografias de resultados de obras de imóveis encortiçados.............. 199 ANEXO G - Fotografias realizadas em "Vistorias Prévias" de imóveis

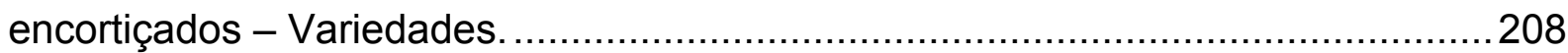

ANEXO H - Fotografias do Livro Cortiços: A experiência de São Paulo. ................214 


\section{Introdução}

\subsection{Histórico}

São Paulo nem sempre foi um dos maiores conglomerados urbanos do mundo. Nos dias atuais, com uma população de 18,3 milhões de habitantes, São Paulo ocupa a quinta posição, da mesma forma que as outras quatro maiores regiões metropolitanas - Tóquio, México, Nova York e Mumbai- nem sempre lideraram esse ranking (Burdett, Sudjic, 2007).

Em 1950, a lista das maiores cidades do mundo era bastante diferente. A Cidade do México e a cidade de São Paulo nem sequer figuravam entre as dez primeiras, enquanto Londres e Paris ocupavam a segunda e quarta posição, respectivamente. Impressionantemente, "a população de São Paulo passou de 15 mil habitantes em 1850 para 65 mil em 1890" (Piccini, 1996), alcançando em 1900 239.820 habitantes. Em 1928 chegamos a 1 milhão de habitantes.

Tabela 1 - Evolução da população. Simões Junior, 1991.

\begin{tabular}{|l|c|c|c|c|c|}
\hline Ano & $\mathbf{1 8 7 2}$ & $\mathbf{1 8 8 6}$ & $\mathbf{1 8 9 0}$ & $\mathbf{1 9 0 0}$ & $\mathbf{1 9 2 0}$ \\
\hline População & 26.040 & 47.697 & 65.000 & 239.820 & 580.000 \\
\hline
\end{tabular}

O processo de imigração e de adensamento nessas metrópoles não seguiu nenhum padrão urbano. Nem poderia. Questões políticas, econômicas, religiosas e calamidades ocorridas em cidades do Velho Mundo ocasionaram um fluxo de imigração incontrolável em nossas cidades. A exemplo disso, podemos ver que, até as três primeiras décadas de 1900, São Paulo recebeu 850 mil imigrantes italianos, 400 mil portugueses e 300 mil espanhóis, ou seja, um crescimento de mais de 1,5 milhão de habitantes em pouco mais de 30 anos (Costa, França e López, 2010).

O problema não está nos processos imigratórios de fato, mas na forma de ocupação do território e no tipo de adensamento ocorrido. Tanto a herança cultural 
na forma de ocupação quanto a ausência de diretrizes urbanísticas do poder público na época - ou, o mais provável, o ineditismo dessa imigração descomunal resultaram, segundo Bonduki (1994), no agravamento das condições urbanas e ainda, colaborando para acentuar os riscos de ordem sanitária, nos últimos quinze anos do século XIX, ocorreu um aumento espantoso da super ocupação das edificações, do índice da carência de habitações de baixo aluguel e da concentração de trabalhadores pobres da cidade.

Nas últimas décadas do século XIX, ações e leis municipais não tratavam o assunto de forma a planejar a expansão e definir as diretrizes de um adensamento que viria a causar transformações substanciais em pouquíssimo espaço de tempo na cidade de São Paulo.

Urbanisticamente a capital bandeirante, originariamente aninhada, por necessidade de defesa contra os índios, numa exígua colina cercada de várzeas e ladeiras, e depois crescida ao sabor da topografia e de arruadores primários, teria forçosamente de suscitar com o tempo, como suscitou, problemas difíceis de correção (Maia, 1954 apud Toledo B. L. 1996, p15).

Foi somente em 1892 que se criou a Intendência de Obras pelo Regimento Interno da Câmara (Lei $n^{\circ} 9$ de 3/12/1892), que traz em seu artigo $1^{\circ}$ a finalidade de sua criação:

Fica criada, na Intendência de Obras, uma Comissão Técnica à qual incumbe a organização do plano ou projeto geral da cidade, fazendo para esse fim os serviços necessários e confeccionando os planos técnicos gerais, parciais e detalhes para o conjunto de obras ou edificações a executar, para retificações, melhoramentos, embelezamentos e tudo o que seja necessário para que a cidade seja colocada em condições estéticas e confortáveis. 
Para Simões Junior (1990, p 62):

Essa Comissão é um marco importante no setor de Obras Municipais na Cidade de São Paulo, porque ela será a primeira instância administrativa criada com a finalidade urbanística, ou seja, visando a elaboração e organização do plano geral da cidade.

No entanto, quanto às preocupações habitacionais, as leis municipais da época se limitavam a conter os malefícios das superlotações existentes nas áreas residenciais da pequena São Paulo de 1900.

O Código de Posturas da Cidade de São Paulo, publicado no ano de 1886, proibiu os cortiços nas proximidades de áreas comerciais e regulamentou a sua construção nos bairros residenciais. Seu artigo 20 dizia: "É prohibida a construcção de cortiços no município da Capital, si não forem rigorosamente observadas às seguintes condições".

Desse ponto em diante, o Código de Posturas traz sete parágrafos que estabelecem exigências às construções. Alguns deles referem-se às questões de densidade, ou melhor, à superlotação existente nesses espaços habitados ${ }^{1}$. Surpreendentemente, o parágrafo terceiro do código exige uma área mínima idêntica à exigida na lei atual. Mais de 100 anos se passaram e a exigência para uma área mínima de cômodos de cortiços não evoluiu. Na última regulamentação, que data de 1991, definem-se como área mínima 5 metros quadrados para cada cômodo de cortiço.

Também são abordados temas ligados à higiene e salubridade, como altura do pé-direito, quantidade de portas e janelas e seu dimensionamento, o que indica certo cuidado com questões de ventilação e iluminação nos cômodos ${ }^{2}$.

\footnotetext{
${ }^{1}$ Texto do vigésimo artigo do Código de Posturas de 1886, parágrafos: "§ $1^{\circ}$ Quando construírem-se cortiços dentro de terrenos, juntos das casas de habitação, devem estes terrenos ter mais de quinze metros de largura. $\S 2^{\circ} \mathrm{Na}$ construcção de cortiços, dentro de quaesquer terrenos, deve conservar-se o espaço, entre cada linha de cortiços, pelo menos de cinco metros. $\S 3^{\circ}$ No caso de constar o cortiço de uma só peça interior deverá elle ter pelo menos, cinco metros quadrados de área".

${ }_{2}$ Texto do vigésimo artigo do Código de Posturas de 1886, parágrafos: "§ $4^{\circ}$ Os cortiços de uma só ou mais peças interiores deverão ter em todas ellas portas e janellas, sendo a largura destas de noventa centímetros a um metro e o duplo correspondente na altura. $\S 5^{\circ} \mathrm{A}$ altura dos cortiços do solo à cimalha poderá variar de quatro a quatro e meio metros".
} 
Ainda antes da virada do século, em 1893 destaca-se o "Relatório da Commissão de Exame e Inspecção das Habitações Operárias e Cortiços no Distrito da Santa Ephigenia". O Relatório caracteriza os cortiços da época, regulamenta aspectos construtivos e traz elementos de zoneamento, proibindo o uso para determinada região, sendo, pois, um documento importante com ricas informações a respeito dessas moradias precárias.

Como podemos observar, em mais de 100 anos o poder público tem observado a existência de cortiços na cidade, ora proibindo sua construção, ora regulamentando, estabelecendo exigências construtivas e muitas vezes zonificando seu uso. No entanto:

No que concerne ao Estado, é inquestionável o fato de que a sua responsabilidade maior, a respeito do direito de acesso da população à terra, como bem de vida garante de casa e comida, está na sua histórica inadimplência em cumprir o princípio da eficiência, previsto no art. 37 da CF. (Alfonsín, Fernandes, 2006, p 171).

Em outras palavras, sem uma fiscalização bem-estruturada e condizente com a explosão demográfica das primeiras décadas de 1900, e, nos dias atuais, sem uma estrutura fiscal capaz de atender às mais diversas demandas da cidade, seria improvável impedir um quadro extenso de irregularidades e de degradações edilícias nesses imóveis de uso residencial que abrigam as camadas socialmente mais vulneráveis da sociedade.

A última regulamentação de cortiços na cidade de São Paulo se dá em 1991 e atualiza a definição desse tipo de ocupação para o município e estabelece um conjunto de regras chamadas, no artigo $3^{\circ}$ da lei, de condições mínimas de habitabilidade para os imóveis, onde algumas exigências dispostas no Código de Obras e Edificações do Município de São Paulo de 1992 foram flexibilizadas.

Assim, em janeiro de 1991 publica-se a Lei n 10.928, a chamada Lei Moura. O vereador Luis Carlos Moura e uma equipe multidisciplinar composta por arquitetos, assistentes sociais e advogados vinculados à Coordenadoria de Habitação, pertencente na época à Secretaria do Bem-Estar Social, elaboraram o 
texto de lei que estabeleceu, de forma inédita, uma definição de cortiços e determinou parâmetros de habitabilidade segundo os quais o poder público municipal deveria atuar e direcionar suas ações.

Junto à lei, publica-se o Decreto Regulamentador $n^{\circ} 33.189 / 91$, que estabeleceu parâmetros segundo os quais um cortiço deveria alcançar condições mínimas de habitabilidade. Além disso, o Decreto institui a primeira Comissão de Intervenção e Recuperação de Cortiços (CIRC), composta por profissionais de secretarias diversas, com o objetivo de debater internamente as diretrizes políticas de intervenção nos imóveis encortiçados.

No momento de sua publicação, a Coordenadoria de Habitação desenvolvia dois importantes projetos na área central da cidade com a perspectiva de concretizar uma atuação que pudesse ganhar escala frente a uma demanda estimada na época em 44 mil famílias (FIPE, 1994) nos distritos da antiga Administração Regional Sé. Dois projetos de edifícios residenciais, Madredeus (45 apartamentos) e Celso Garcia (182 apartamentos), ambos na Mooca, marcam intervenções pioneiras na área central, além de projetos similares que foram realizados na continuidade, como o Imoroti (8 apartamentos), no Ipiranga, e Eiras Garcia (15 apartamentos) e Pedro Facchini (12 apartamentos), no Cambuci.

Ao longo desse processo de intervenções na área central, a CIRC iniciava seus trabalhos, cujo objetivo era a elaboração de diretrizes políticas para intervenção em imóveis encortiçados e tinha como principal desafio a aplicação de uma lei municipal cuja repercussão atingiria nada menos que uma população assentada em imóveis encortiçados em toda a cidade de São Paulo, estimada, em 1994, pela Fundação Instituto de Pesquisas Econômicas (FIPE) em 595.110 habitantes (FIPE, 1994).

Entretanto, passados dois anos sem a aplicação da lei, em 1993 o gabinete da Secretaria Municipal de Habitação e Desenvolvimento Urbano de São Paulo (Sehab) autuou um processo administrativo de $n^{\circ}$ 1993-0.001.308-4, que, em sua segunda página, diz:

O Secretário da Habitação e Desenvolvimento Urbano, no uso de suas atribuições, e considerando as indicações dos órgãos públicos e das 
entidades representativas da sociedade civil, RESOLVE: - Constituir Comissão para, no prazo de quarenta e cinco dias, apresentar diretrizes objetivando a formulação de uma política habitacional para os cortiços, tendo em vista os próximos quatro anos de governo.

E fica assim criada a Comissão incumbida de elaborar uma política habitacional de atuação em cortiços para a cidade de São Paulo.

O processo administrativo tem ao todo 365 páginas, sendo que a última cota ${ }^{3}$, escrita oito anos depois, em 12 de julho de 2001, e encaminhada para o gabinete da Superintendência de Habitação Popular, diz: "Para ciência e caso haja interesse mantê-lo sob custódia". Mais uma vez, o poder público fica omisso em face de uma realidade já regulamentada um século atrás, mas que urge ser fiscalizada.

Para Piccini (1996), existiram poucas experiências promovidas pelo setor público para enfrentar a problemática da fixação da população encortiçada no centro da cidade. Ainda segundo o autor, em sua tese:

A justificativa da escolha desse período (1986 a 1995) deve-se ao fato que nesses últimos 10 anos as administrações municipais atuaram na cidade de São Paulo de forma diferenciada, alternada e contrária, em relação ao problema de cortiços no centro da cidade por causa de suas próprias orientações políticas. Em alguns casos, apontado a necessidade de resolver a situação dos cortiços, como um problema relacionado a uma visão urbana de conjunto dentro de um Plano Diretor. Em outros, de resolver o mesmo problema por meio de intervenções pontuais, dependendo do caso, e sobretudo das oportunidades políticas do momento. Em outras ainda, agindo como se o problema não existisse (Piccini, 1996, p 9)

${ }^{3}$ Diz-se de informações de prosseguimento no envio de um processo administrativo de uma repartição pública para outra. 
Para Brandão (2003, p 155),

[...] as políticas públicas sofrem pela falta de planos e diretrizes concretas que assegurem a sistematização de operações nesses setores onde a habitação de interesse social ainda não chegou. A identificação dos setores mais oportunos do ponto de vista urbanístico, dos instrumentos que estimulem a produção nestas áreas, como as zonas especiais de interesse social, da revisão de legislação (uso do solo, normas edilícias) são ações indispensáveis que o município deve realizar para permitir que estas áreas cumpram sua função social, equilibrando o acesso aos serviços para um enorme contingente de cidadãos, que nesta cidade vivem na clandestinidade.

O debate a respeito do problema dos cortiços, explícito no processo administrativo citado, não se esgotou na época e, ao que consta, parece ter absorvido tempo em demasia em tentativas de estruturações burocráticas com resultados práticos muito aquém da urgência em intervir nessas habitações precárias.

Basicamente, erradicação ou regularização são os principais pontos de divergência de técnicos, políticos e representantes da sociedade civil ao longo dos 19 anos da publicação da Lei Moura, com forte argumentação para ambas as linhas de atuação.

Para uns, a erradicação total dos cortiços é a única solução e, para outros, a adequação à lei vigente seria nada mais que suficiente. Mais tarde se reconheceria que as duas soluções poderiam coexistir e mostrar eficiência. Todo esse debate e conhecimento, acumulado na Secretaria Municipal de Habitação, condensou-se, em novembro de 2005, numa única medida: a aplicação, de fato, da Lei Moura.

O plano das obras de reforma de 1.000 cortiços no centro da cidade de São Paulo baseia-se nessa legislação. 


\subsection{Histórico da legislação incidente ao longo do século XIX e XX}

\subsubsection{Legislação até fins do século XIX}

Os quartos, cortiços, casas de quitandas, tavernas, casas de pasto, estalagens, armazens de mantimentos, albergaria de vaccas, cocheiras, casas em que se trabalhe com matérias animaes e vegetaes, e em geral todo e qualquer estabelecimento em que se agglomere grande número de pessoas, serão caiadas no interior duas vezes ao anno, nos mezes de Janeiro e Julho; sob pena de $10 \$$ de multa ao infractor.

O texto acima é do artigo $89^{\circ}$ do Código de Posturas da Camara Municipal da Imperial Cidade de São Paulo, publicado em 1875.

Pode-se entender esse artigo como uma intenção de regulamentar, mesmo que não se faça distinção entre o uso residencial e outros; porém, as construções não residenciais eram regulamentadas com ênfase no alinhamento das novas edificações e nos novos arruamentos. Ao longo dos demais capítulos que compõem o Código, temas como escolas, hospitais e matadouros são abordados sem uma definição de regras específicas e detalhadas para a construção de habitações nem tampouco de cortiços.

Não há registros precedentes ao Código de Posturas da Cidade de 1886 que abordem o tema dos cortiços de maneira tão detalhada e com estabelecimento de regras tão específicas. Essa legislação, pela primeira vez, dispõe sobre regras a serem adotadas na construção de cortiços. O seu artigo $20^{\circ}$ do Título II, que trata da "Edificação e Reedificação do Calçamento", proibia a construção dos cortiços se não fossem seguidas determinadas exigências relacionadas, por exemplo, ao dimensionamento dos terrenos, ao espaçamento entre cada habitação ${ }^{4}$ dentro do

\footnotetext{
${ }^{4}$ No texto original do artigo consta: [...] espaçamento entre cada cômodo [...]. Aqui interpretado como "habitação" por tratar-se do espaçamento existente entre os dormitórios construídos ao longo do terreno do cortiço.
} 
lote, áreas mínimas dos cômodos e outras características construtivas, como o dimensionamento de portas e janelas, pé-direito e tratamento do solo, e contrapiso.

O artigo 21, inclusive, definia sanções aos proprietários de cortiços: "Os contraventores do artigo antecedente e seus paragraphos, serão obrigados ao pagamento de $30 \$ 000$ de multa e à demolição das obras já feitas".

O Padrão Municipal, também de 1886, em seu Capítulo VI, tratava de "Cortiços, Casas de Operários e Cubículos" e proibia a construção no perímetro do comércio, além de exigir licença para construir, que deveria ser solicitada à Câmara, e que fossem observadas exigências ${ }^{5}$ relacionadas às áreas comuns dos cortiços e à distribuição de torneiras e tanques de lavar para cada cômodo.

No caso dos banheiros, segue-se a mesma quantidade dos tanques de lavar roupa: um para cada grupo de vinte pessoas. A lei de 1886 é bem mais exigente, como vemos a seguir: "3a Haverá uma latrina para cada grupo de duas habitações. Estas latrinas terão água sufficiente para o aceio necessário".

O Padrão Municipal trazia, inclusive, uma preocupação com as áreas de uso comum, como vemos:

$4^{\text {a }}$ A área commum das frentes das habitações ou arruella de passagem, deverá ser convenientemente arborisada. $5^{\mathrm{a}} \mathrm{A}$ entrada commum deverá ser fechada por um muro com portão de ferro ou de madeira, caso a Camara julgue conveniente. $6^{\mathrm{a}}$ Cada habitação deverá ter uma área calçada, de serviço interior, com 12 metros quadrados pelo menos.

Estabelece critérios para o período de chuvas: "7a 0 terreno em que forem construídas estas habitações, deverá ter nivelamento regular, de modo a dar livre escoamento às águas pluviaes."

Na lei atual, o pé-direito mínimo é de 2,30 metros, muito menor que o exigido na época: "8a Quando as habitações tiverem um só pavimento, o seu pé direito não

\footnotetext{
${ }^{5}$ Texto integral: "1a Haverá uma área nas frentes das habitações, podendo parte ser reservada a um pequeno jardim e o resto calçado. Esta área será na razão de 30 metros quadrados para cada habitação, sendo toda calçada, caso não se reserve alguma porção para jardim. $2^{\mathrm{a}}$ Haverá um poço ou torneira com água e pequeno tanque de lavagem para cada grupo de seis habitações no máximo".
} 
poderá ser inferior a 4 metros. Quando de dous pavimentos, o $2^{\circ}$ poderá ter no mínimo 3,5 m de pé direito".

No Código de Posturas de 1886, não temos referenciadas as aberturas dos vãos das janelas com as áreas de piso. No entanto, podemos notar que as aberturas são generosas, como vemos a seguir:

$9^{\text {a }}$ As portas do $1^{\circ}$ pavimento terão $2,75 \mathrm{~m} \times 1,10 \mathrm{~m}$ de vão, para limite mínimo; as janellas de peitoril, $1,85 \mathrm{~m} \times 1,00 \mathrm{~m}$ de vão, para limite mínimo também. As janellas de peitoril do $2^{\circ}$ pavimento terão $1,70 \mathrm{~m} \times$ $1,00 \mathrm{~m}$ (também limite mínimo). $10^{\mathrm{a}}$ Todas as aberturas exteriores serão munidas de caixilhos envidraçados, excepto a porta de entrada da habitação.

Outras definições de ordem geral foram estabelecidas, como, por exemplo, o tratamento dos soalhos, o acabamento das paredes internas, o dimensionamento de cômodos, inclusive sua área mínima, que na época foi definida em $7,5 \mathrm{~m}^{2}$. $\mathrm{Na}$ lei atual é adotado o mínimo de $5 \mathrm{~m}^{2}$ por cômodo 6 .

O Padrão Municipal de 1886 é bastante completo, com informações e exigências muito mais contundentes que as contidas no Código de Posturas de 1875. Exige aberturas para o exterior em todos os cômodos, de maneira a favorecer a ventilação e a iluminação, a declividade de escadas, a largura de escadas e o assentamento do soalho do primeiro pavimento ${ }^{7}$.

Sete anos depois, o "Relatório da Commissão de Exame e Inspecção das Habitações Operárias e Cortiços no Distrito da Santa Ephigenia, de 19 de Outubro de 1893", caracterizou os cortiços da época, e é de surpreender que muitas de suas observações de 100 anos atrás se mantêm até hoje sem muitas diferenças.

\footnotetext{
6 " $11^{\text {a }}$ Os soalhos do $1^{\circ}$ pavimento serão pelo menos ladrilhados com tijolos communs, sendo todos os commodos de habitações soalhados de madeira. $12^{\mathrm{a}}$ As paredes deverão ser interiormente rebocadas e caiadas. $13^{\mathrm{a}} \mathrm{O} 1^{\circ}$ pavimento deverá ser sempre forrado. $14^{\mathrm{a}}$ Cada habitação deverá ter pelo menos três commodos e cada commodo não poderá ter área menor de $7,5 \mathrm{~m}$ quadrados."

" $15^{\text {a }}$ Todos os cômmodos deverão ter aberturas para o exterior, de modo que disponham amplamente de ar e luz. $16^{\text {a }}$ As escadas deverão ter como limite máximo de declividade, 80 de altura por 100 de horisontal. Os contradegráos deverão ser fechados. A largura da escada nunca poderá ser inferior a 80 centímetros. $17^{\mathrm{a}} \mathrm{O}$ nível do soalho do $1^{\circ}$ pavimento será sempre superior ao do solo 50 centimetros no mínimo."
} 
No Capítulo III, que trata do "[...] typo das estalagens, cortiços ou habitações operárias entre nós", está escrito:

$\mathrm{Na}$ zona affectada a que nos temos referido, as habitações destinadas às classes operarias, são numerosas. Existem ahi nada menos de 60 cortiços de todos os tamanhos e feitios onde se agasalha uma população de 1.320 individuos de todas as nacionalidades e condições. Estas habitações são, de ordinário, do typo Cortiço, no geral, bem pouco confortáveis.

O Relatório é um dos poucos documentos que expressam com precisão o tipo de precariedade vivenciada na época pelas classes operárias usuárias de cortiços:

O cortiço occupa commumente uma área no interior do quarteirão; quase sempre um quintal de um prédio onde há estabelecida uma venda ou tasca qualquer. Um portão latteral da entrada por estreito e comprido corredor para um pateo com $3 \mathrm{~m}$ a $4 \mathrm{~m}$ de largo nos casos mais favorecidos. Para este pateo, ou área livre se abrem as portas e janellas de pequenas casas enfileiradas, com o mesmo aspecto, a mesma construç̧ão, as mesmas divisões internas e a mesma capacidade. Raramente cada casinha tem mais de 3 metros de largura, 5 a 6 de fundo e altura de 3 a 3,50, com uma capacidade para 4 pessoas, quando muito.

Ainda no Capítulo III se estabelece a caracterização dos cortiços da época que poderia muito bem ser usada nos cortiços atuais:

Entre nós os cortiços se caracterisam: $1^{\circ}$ pela má qualidade $\mathrm{e}$ improbidade das construcções; $2^{\circ}$ pela falta de capacidade e má distribuição dos aposentos, quasi sempre sem luz e sem a necessária ventilação. $3^{\circ}$ pela carência de prévio saneamento do terreno onde se acham construídos; $4^{\circ}$ finalmente pelo desprezo das mais comesinhas regras de hygiene domestica.

O Relatório, em seu Capitulo IV, trata da distribuição dos cortiços na região de Santa Ifigênia e nos dá alguns parâmetros da densidade: 
Nessa zona deprimida que representa uma superficie de 14 hectares entre as ruas do Visconde do Rio Branco, Victoria, Bom Retiro e Duque de Caxias não há menos de 43 cortiços, occupando os de Carlos Girardi, que são maiores e mais densamente povoados, os pontos mais baixos e mais próximos do primitivo talweg da lagôa. Estão ahi, portanto, mais de dois terços dos cortiços examinados no districto de Santa Ephigenia. Estes 43 cortiços ou estalagens contêm 281 cubiculos ou casinhas com uma população de 965 individuos. Cerca de uma quarta parte dessa população (231 individuos) representa o excesso de lotação indicado pelos moradores, excesso que avultará se uma policia noturna se applicar escrupulosamente no exame estatístico de povo que eventual ou permanentemente vêm occupar os cortiços à noite.

Podemos concluir que cada cortiço teria em média 6,5 cômodos, cada cômodo com 3,5 pessoas em média, ou 22,4 pessoas por cortiço. Nada diferente dos cortiços atuais. Estima-se que a média de cômodos por cortiços na Subprefeitura da Mooca seja de 9,89 e cada cômodo com 1,9 pessoa em média (Costa, França e López, 2010).

O Capitulo V do Relatório de 1893 estabelece as medidas a serem tomadas em relação aos cortiços. Primeiramente propõe-se a proibição da construção de novos cortiços nessa região e que os existentes sejam submetidos a um "regimen todo especial de polícia e de hygiene que lhes cortem os abusos pela raiz".

O Relatório classifica os cortiços ou habitações operárias em dois tipos: "O cortiço propriamente dito, do typo normal já descripto, e a casa de alugar commodos para dormida que é um prédio qualquer adaptado a este mister".

São diversas as exigências do Relatório para que um cortiço continue a funcionar. Entretanto, as medidas que chamam a atenção são referentes à quantidade de latrinas e tanques de lavar roupa. No caso das latrinas, o relatório exige uma a cada duas habitações. Muito mais rígido que a lei atual, que estipula um vaso sanitário para cada grupo de 20 pessoas. No caso dos tanques de lavar roupa, o Relatório exige um para cada grupo de seis habitações, também mais rígido do que a lei atual, que exige um tanque para cada grupo de 20 pessoas. As demais 
medidas são referentes ao tratamento do piso dos cômodos; medidas relativas às instalações hidráulicas, entre outras ${ }^{8}$.

Especificamente em relação aos cômodos dos cortiços, o Relatório traz exigências importantes referentes à ventilação e iluminação e, inclusive, ao uso de ventiladores e de iluminações zenitais. A cozinha fica também regrada, assim como o revestimento dos ambientes ${ }^{9}$.

Pelo Relatório, as casas de alugar cômodos ficaram proibidas na região de Santa Ifigênia, e as existentes ficam com regras semelhantes à dos cortiços ${ }^{10}$.

\footnotetext{
8 " $1^{\circ}$ Ter a área livre em nível superior as da rua; estar calçada e cimentada a sua largura si for inferior a 4 metros, ter um ralo de exgotto a cada 30 metros quadrados de superfície, ter sargêtzas abertas no sentido longitudinal do terreno para a drenagem superficial. $2^{\circ} \mathrm{A}$ arborisação só será permitida se a área livre tiver largura maior de 5 metros; neste caso a calçada e cimentação serão dispensadas na parte plantada. $3^{\circ}$ Ter o systema de exgotto completo para as latrinas, as quaes deverão ser assentadas no fundo da área livre e contendo, sob abrigo adequado, tantas bacias quantos grupos de duas habitações, sendo o chão ladrilhado e cimentado e completamente estanque. Nenhuma latrina será installada sem o competente serviço d'agua. $4^{\circ}$ Ter água canalisada para uso domestico sendo para esse fim assentadas tantas torneiras quantos os grupos de seis casas. Os poços são ahi completamente banidos. $5^{\circ}$ Ter tanques para lavagens de roupa, tantos quantos os grupos de seis casas, sendo elles cimentados ao redor e munidos de ralos para exgotto. $6^{\circ} \mathrm{A}$ entrada commum deve ser fechada por um muro com portão de ferro ou de madeira, sendo pintado este com duas cores (vermelho e preto) divididas no sentido diagonal. No alto do portão se collocará uma taboleta como o nome - estalagem. $7^{\circ} \mathrm{Na}$ área livre serão assentados lampeões: um na entrada e outro na posição mais conveniente para ter essa área perfeitamente illuminada."
}

9 " $1^{\circ}$ As casas com pé direito de $3 \mathrm{~m}, 5$ a $4 \mathrm{~m}$ deverão ter ventilador aberto no forro do tecto ou na bandeira da porta de sahída. $2^{\circ}$ Serão abertos ventiladores na porta de todas as alcovas, sendo estas forradas. $3^{\circ}$ Collocar telhas de vidro ou abrir clarabóias naquelles commodos onde a illuminação for insufficiente. $4^{\circ}$ Melhorar o soalho levantando-o 25 centímetros e abrindo-lhes frestas de ventilação para o lado exterior. $5^{\circ}$ Proceder com regularidade a reparos no reboco e fazer caiação interior ao menos uma vez por anno, não sendo permittido o emprego do papel para forro. Essas medidas de asseio, porém, poderão ser exigidas mais vezes, sempre que as circunstâncias o exigirem. $6^{\circ} \mathrm{O}$ cômmodo destinado a cosinha, deverá ser soalhado de preferência, podendo entretanto ser ladrilhado ou cimentado. $O$ fogão terá sempre uma chaminé e será eliminado o forro do tecto. $7^{\circ} \mathrm{As}$ casas que tiverem pequena área no fundo, nunca menos de 10 metros quadrados, te-la-ão cimentada e com a sufficiente inclinação para um ralo de exgotto que facilite a drenagem. $8^{\circ}$ Nesta área do fundo não serão toleradas latrinas sem água e sem competente abrigo. $9^{\circ}$ Todas as casinhas ou cubículos serão numerados e a competente lotação determinada de modo a não ser excedida, guardando-se sempre a proporção de 15 metros cúbicos por pessoa. $10^{\circ}$ Os moradores de cada casinha serão inscriptos num livro rubricado pela policia e não poderão ser em maior numero que o determinado pela lotação. Os delegados de hygiene e os fiscais exigirão esse livro sempre que o quizerem por necessidade de serviço."

10 "10 Não serão mais abertas casas deste gênero dentro da zona circumscripta pelas ruas Duque de Caxias, Visconde do Rio Branco, Victoria, Bom Retiro e Largo do General Ozório. $2^{\circ}$ Não poderão ser estabelecidas em prédios térreos ou que não tenham o soalho levantado do chão ao menos 50 centímetros. $3^{\circ}$ Deverão ter esses prédios, uma área interior, servindo para ventillar e illuminar os aposentos de dormir, os quaes não poderão ser transformados por meio de obras provisórias sem que preceda licença do poder competente. $4^{\circ} \mathrm{O}$ proprietário não poderá fazer obras de adaptação para taes estabelecimentos sem que apresente descripção e planta detalhada do interior de prédio e 
No Capítulo VI, o Relatório dá orientações referentes aos cortiços que devem ser interditados. Informa que não são poucos os cortiços condenados na área levantada. Segundo o Relatório: "As condições hygienicas de taes habitações são tão desfavoráveis que o recurso único, mais prompto a lançar-se mão por agora, é propor-lhes - o interdicto".

O Relatório diz ainda que o poder público não pode tolerar esses imóveis com tais condições de higiene e instrui o poder público a estar preparado para:

$1^{\circ}$ Para lançar-Ihes o interdicto, coagindo os moradores a desoccupálos em prazo curto e sendo intimados os proprietários a reformal-os, sob plano approvado, antes de os poder alugar novamente. $2^{\circ}$ Para exigir a demolição de prédios condemnados para os quaes não haja concertos ou reparos possíveis. $3^{\circ}$ Para fazer a desapropriação por utilidade publica daquellas construcções que forem condemnadas pela hygiene e de que haja conveniência na reedificação sob typo especial approvado.

A interdição é vista, no documento, como o recurso mais eficaz e de medida preventiva mais rápida. O Relatório também comenta que a demolição do imóvel é um recurso disponível pelo poder público, que poderá utilizá-lo como medida de segurança. Outro recurso citado pelo relatório é a desapropriação do imóvel, entendida como uma medida mais enérgica. Uma vez com a posse do imóvel, o poder público poderá proceder à demolição da construção e posteriormente à execução de vila operária "[...] do typo que a hygiene apontar como mais adequado à população a que vai servir".

Um ano após a publicação do relatório da Santa Efigênia ocorre a promulgação do Código Sanitário por meio do Decreto $n^{\circ} 233$ de 2 de Março de 1894. O Decreto estabelece regras para a construção de habitações, hotéis, casas de pensão e inclusive habitações coletivas, tendo em vista principalmente os aspectos de ventilação, insolação e drenagem de águas fluviais e águas pluviais. $O$ Capítulo $V$ do Decreto trata das HABITAÇÕES DAS CLASSES POBRES e em seu 
artigo 138 determina: "Deve ser terminantemente prohibida a construcção de cortiços, convindo que as municipalidades providenciem para que desapareçam os existentes."

No entanto, sabemos que a realidade social e as condições de habitação das classes menos favorecidas impunham um padrão higiênico bem diferente daqueles impostos pelo Código Sanitário. Sendo assim as habitações coletivas e os cortiços continuaram existindo por muito mais tempo, mesmo que clandestinamente, pois se constituiam no único meio de acesso possível à habitação para as classes operárias paulistanas (e que até hoje subsiste em padrões tão insalubres quanto há cem anos atrás)" (SIMÕES JUNIOR, 1990, p 59).

Após este último regramento, avançaríamos muitos anos no século $X X$ sem novas determinações para os imóveis encortiçados na cidade de São Paulo. 


\subsubsection{Lei $\mathrm{n}^{\circ} 10.928$ de 1991 - Lei Moura}

Publicada em 8 de janeiro de 1991, pelo Projeto de Lei n 504/89, do vereador Luiz Carlos Moura, a lei passa a definir e regulamentar cortiços na cidade de São Paulo e torna-se conhecida como Lei Moura, trazendo como principal valor a definição do que se é entendido como cortiço pelo poder público na cidade de São Paulo.

Até então, cortiço era toda e qualquer habitação coletiva, e até mesmo unifamiliar, que apresentasse péssimas condições de salubridade, imóveis deteriorados, com instalações de rede de água e esgoto inadequadas, deterioração de fachadas e de áreas comuns, mau funcionamento do banheiro, da área de serviço, de tanques, varais, etc.

Logo em seu artigo $1^{\circ}$, a lei estabelece o que é um cortiço, consolidando informações técnicas e, da mesma forma, culturais sobre esse tipo de habitação. Assim, diz:

Art. $1^{\circ}$ - Define-se cortiço como a unidade usada como moradia coletiva multifamiliar, apresentando, total ou parcialmente, as seguintes características:

a) constituída por uma ou mais edificações construídas em lote urbano;

b) subdividida em vários cômodos alugados, subalugados ou cedidos a qualquer titulo;

c) várias funções exercidas no mesmo cômodo;

d) Acesso e uso comum dos espaços não edificados e instalações sanitárias;

e) Circulação e infra-estrutura, no geral precárias;

f) Superlotação de pessoas.

$\mathrm{O}$ artigo $2^{\circ}$ não é menos contundente. Estabelece categoricamente a responsabilidade do poder público municipal quanto à fiscalização das condições habitacionais nos cortiços. Em seu parágrafo único responsabiliza não somente o proprietário do imóvel como também, com o mesmo peso, o locatário-sublocador ou qualquer outro que exerça a exploração do cortiço: 
Art. $2^{\circ}$ - A prefeitura fiscalizará as condições de habitação nos cortiços e tomará as medidas necessárias para fazer respeitar as exigências da presente lei e demais normas pertinentes, atendendo as necessidades da população moradora.

Parágrafo único - Serão solidariamente responsáveis pelas condições de habitação, perante o poder Público, o proprietário, o locatário-sublocador, terceiros que tomem o lugar destes e/ou o responsável pela exploração do cortiço.

O artigo $3^{a}$ é enfático. Estabelece condições mínimas de habitabilidade nos cortiços, flexibilizando em alguns casos o código de obras do município.

Art. $3^{\circ}$ - Independentemente de outras normas aplicáveis, consideram-se as condições mínimas de habitação, para os fins desta lei, as seguintes:

a) segurança do imóvel no tocante à sua instalação elétrica e à sua estrutura, comprovadas através do laudo expedido pelo órgão público competente, renovado a cada dois anos;

b) iluminação mínima por cômodo 1/7 (um sétimo) da área de piso;

c) ventilação mínima por cômodo de metade da área de iluminação;

d) área mínima do cômodo ou divisão não inferior a $5 \mathrm{~m}^{2}$ (cinco metros quadrados), com sua menor dimensão não inferior a 2 (dois) metros;

e) adensamento máximo de 2 (duas) pessoas por $8 \mathrm{~m}^{2}$ (oito metros quadrados), considerando toda a área construída da edificação, vedado o revezamento;

f) banheiro revestido de piso lavável e de barra impermeável até 2 (dois) metros de altura;

g) os banheiros serão dotados, pelo menos, de vaso sanitário, lavatório e chuveiro em funcionamento, compartimentos, sempre que possível, de forma independente, com abertura para 0 exterior;

h) haverá no mínimo 1 (um) tanque, 1 (uma) pia e 1 (um) banheiro para cada grupo de 20 (vinte) moradores; 
i) o pé direito será de, no mínimo, 2,30m (dois metros e trinta centímetros);

j) as escadas e corredores de circulação terão, pelo menos, 80 (oitenta) centímetros de largura;

A lei autoriza o poder público a usar de tolerância em relação a alguns parâmetros do artigo $3^{\circ}$. Isto é, além de já haver uma flexibilização do Código de Obras, a Lei Moura dá permissão ao técnico da prefeitura para tolerar não conformidades em relação a alguns parâmetros mínimos de habitabilidade.

Muito interessante observar que a lei atribui obrigatoriedades que podem ser interpretadas como intenções de gestão dos imóveis. No parágrafo único do artigo $6^{\circ}$, estabelece a obrigatoriedade da prefeitura em realizar cadastro dos imóveis enquadrados na categoria de cortiços.

No parágrafo $1^{\circ}$ do artigo $7^{\circ}$, a lei impõe penalidades para aqueles que não obedecerem a exigências tais como: aplicação de multa de 20 a 200 UFM's $^{11}$ e ainda, no parágrafo $2^{\circ}$ do mesmo artigo, a interdição do imóvel para aqueles cortiços que evidenciarem grave e iminente risco à vida ou à saúde de seus moradores.

A lei prevê, inclusive, que o Poder Executivo possa criar programas específicos voltados para melhoria dos cortiços através de financiamentos ou assistência técnica visando sua adequação aos parâmetros previstos na lei.

Além da publicação da Lei Moura, em 17 de maio de 1993 foi publicado o Decreto Regulamentador $n^{\circ}$ 33.189. Aqui fica criada a Comissão de Intervenção e Recuperação dos Cortiços (CIRC), órgão colegiado da prefeitura responsável pelo gerenciamento das medidas necessárias ao atendimento das exigências da lei.

A comissão é composta por 7 (sete) membros das Secretarias Municipais de Habitação, Coordenadoria de Subprefeituras, Saúde, Família e Bem-Estar Social e Secretaria dos Negócios Jurídicos.

Uma das atribuições de extrema importância da CIRC é a sistematização das informações sobre a situação dos imóveis enquadrados na categoria de cortiço,

\footnotetext{
${ }^{11}$ No mês de março de 2010 , o valor da UFM estava cotado em $\mathrm{R} \$ 96,33$, equivalendo a uma multa de $\mathrm{R} \$ 19.266,00$.
} 
quanto ao aspecto físico e jurídico. Mais uma vez, vemos que a lei estabelece diretrizes relacionadas à gestão.

O artigo $9^{\circ}$ do Decreto Regulamentador estabelece a atuação da prefeitura em relação às ações de interdição dos imóveis que se recusarem a executar as melhorias necessárias ou que se encontrem em estado que ponha em risco grave e iminente os moradores ou a vizinhança.

As avaliações físicas dos imóveis para interdição se configuram como tema bastante delicado, pois podem acarretar problemas de desalojamento de famílias. No entanto, a prefeitura poderia, através do Departamento de Controle do Uso de Imóveis (CONTRU), ou subprefeitura competente, proceder à interdição imediata do cortiço. No artigo 10, o Decreto institui o procedimento de intimação do proprietário do imóvel para a execução de obras ou serviços necessários à eliminação do risco.

Ainda o parágrafo único do artigo 10 define que o mesmo procedimento poderia ser adotado também em relação aos cortiços que não apresentem risco grave e iminente, desde que as condições de habitabilidade estejam extremamente degradadas segundo critérios da Comissão de Intervenção e Recuperação dos Cortiços.

De acordo com o Decreto, fica a Superintendência de Habitação Popular incumbida de exercer a supervisão e fiscalização de todas as fases do Programa de Cortiços, cabendo-lhe verificar o cumprimento das normas e regulamentos pertinentes, bem como estimular a formação e organização dos moradores de cortiços em associações ou entidades representativas, para discussão e acompanhamento dos projetos a serem realizados, além de prepará-los para a administração conjunta da nova moradia.

A Lei Moura direciona seus encaminhamentos de maneira clara para as questões físicas do imóvel e para providências de caráter administrativo e de gestão. Entretanto, associada às regulamentações da Lei do Inquilinato, apresenta um quadro completo de subsídio e de diretrizes para o alcance da segurança na posse requisito de extrema importância mencionado na definição de moradia digna, segundo o Plano Diretor Estratégico. 


\subsubsection{Lei Federal $n^{\circ} 8.245$ de 1991 - Lei do Inquilinato}

Dez meses após a publicação da Lei Moura, publica-se em 18 de outubro de 1991 a Lei $n^{\circ}$ 8.245. De acordo com Monteiro (1999):

[...] formou-se único diploma legal para tratar de temática da locação predial urbana, eis que, anteriormente a ela, existiam várias leis e decretos abordando o tema, inclusive o Decreto $n^{\circ} 24.150$, de 20.04.34. A nova lei não apenas simplificou assunto tão palpitante e envolvente, mas, igualmente, evitou o confronto entre locatários e locadores, além de trazer várias inovações.

Entre elas:

[...] a inclusão das locações em shopping centers e dos cortiços (habitações coletivas multifamiliares), que vieram estabilizar os diretamente envolvidos e evitando-se a convulsão social, ampliando os direitos dos locatários, agora com direito a votar nas assembléias de condomínios nos assuntos que versem sobre as despesas que the couberam, bem como a obrigação dos senhorios em exibir os comprovantes das despesas cobradas e a sua discriminação e comprovação, a qualquer tempo, ainda que finda a locação.

Ainda segundo Monteiro, uma das vantagens trazidas pela lei é:

[...] a redução do valor dos aluguéis nas grandes cidades, tendo em vista a maior oferta de imóveis colocados à disposição dos locatários pelos locadores, mais confiantes e seguros; a harmonia que impera entre senhorio e inquilinos que, com tranquilidade, reduzem ou majoram os aluguéis sem nenhum trauma e, mesmo, ampliando as vantagens aos locatários em muitos casos (carência de um mês na locação, descontos no locativo etc.).

Especificamente em relação aos cortiços, a Lei do Inquilinato traz esclarecimentos essenciais à compreensão das relações locatícias estabelecidas nos imóveis encortiçados. 
No capítulo que trata de assuntos gerais da locação, a responsabilidade do locatário e dos sublocatários é a mesma perante o locador no que diz respeito a direitos e deveres de ambos os lados. Para um imóvel concebido originalmente como unifamiliar e que, com o passar dos anos, tornou seu uso multifamiliar, a atribuição de responsabilidades para sublocadores e sublocatários torna a relação condominial sustentável.

Outra medida que fortalece a questão da segurança no relacionamento locatício é o inciso IV do artigo $9^{\circ}$, que traz uma definição importante para o tema das reformas nos cortiços, pois estabelece que a realização de reparações urgentes determinadas pelo poder público, e que não possam ser normalmente executadas com a permanência do locatário no imóvel, permite o desfazimento da locação.

No artigo 21, a lei traz uma definição de extrema importância. Estabelece uma relação entre o valor pago pelo sublocador ao locatário e o valor total pago ao sublocador pelos sublocatários. O aluguel da sublocação não poderá exceder o da locação. Especificamente em relação aos cortiços, estabelece que a soma dos aluguéis não poderá superar o dobro do valor da locação. Claramente uma medida que regula a superlotação do imóvel.

A não observância dessa exigência pode acarretar a prisão simples de cinco dias a seis meses ou multa equivalente ao valor de três a 12 meses do último aluguel atualizado. Outra situação que pode culminar em prisão é a cobrança antecipada do aluguel, salvo a hipótese de locação para temporada. Mais uma vez, a lei traz medidas relacionadas à segurança na posse.

Constitui um crime de ação pública nos cortiços, punível com detenção de três meses a um ano, que poderá, inclusive, ser substituída pela prestação de serviços à comunidade, o fato de recusar-se o locador ou sublocador a fornecer recibo discriminando o valor do aluguel e encargos; e executar o despejo indiscriminado com a inobservância do disposto no artigo de lei que trata do tema. Aqui temos exigências previstas na lei que contribuem para o regimento interno do cortiço, remetendo-se mais uma vez à segurança na posse.

O artigo 21 cria condições de minimizar exageros na exploração do valor do aluguel cobrado pelo sublocador e ainda dá poderes ao sublocatário de reduzir aluguel até os limites estabelecidos. 
Outras medidas de segurança que podem evitar a deterioração em um imóvel encortiçado são expressas em diversos artigos da lei. Como exemplo podemos citar as obrigações do locador referentes à entrega do imóvel em estado de servir ao uso a que se destina, assim como responder pelos vícios ou defeitos anteriores à locação e ainda pelo pagamento das despesas necessárias à pintura das fachadas, empenas, poços de aeração e iluminação, e principalmente as obras destinadas a repor as condições de habitabilidade do edifício e a instalação de equipamentos de segurança e de incêndio ${ }^{12}$.

Por outro lado, o locatário fica obrigado a realizar a imediata reparação dos danos verificados no imóvel, ou nas suas instalações, provocados por ele mesmo, assim como entregar imediatamente ao locador qualquer intimação, multa ou exigência de autoridade pública recebida por ele, locatário ${ }^{13}$.

Nos cortiços, os locatários ou sublocatários poderão depositar judicialmente o aluguel e encargos se a construção for considerada em condições precárias pelo poder público e se o imóvel necessitar de reparos urgentes, cuja realização incumba ao locador, o locatário é obrigado a consenti-los.

\footnotetext{
12 Parágrafo único do artigo 22: Por despesas extraordinárias de condomínio se entendem aquelas que não se refiram aos gastos rotineiros de manutenção do edifício, especialmente: a) obras de reforma ou acréscimos que interessem à estrutura integral do imóvel; b) pintura das fachadas, empenas, poços de aeração e iluminação, bem como das esquadrias externas; c) obras destinadas a repor as condições de habitabilidade do edifício; d) indenizações trabalhistas e previdenciárias pela dispensa de empregados, ocorridas em data anterior ao início da locação; e) instalação de equipamentos de segurança e de incêndio, de telefonia, de intercomunicação, de esporte e de lazer; f) despesas de decoração e paisagismo nas partes de uso comum; g) constituição de fundo de reserva.
}

${ }^{13}$ Incisos I a IX do artigo 23: O locatário é obrigado a: I - pagar pontualmente o aluguel e os encargos da locação, legal ou contratualmente exigíveis, no prazo estipulado ou, em sua falta, até o sexto dia útil do mês seguinte ao vencido, no imóvel locado, quando outro local não tiver sido indicado no contrato; II - servir-se do imóvel para o uso convencionado ou presumido, compatível com a natureza deste e com o fim a que se destina, devendo tratá-lo com o mesmo cuidado como se fosse seu; III restituir o imóvel, finda a locação, no estado em que o recebeu, salvo as deteriorações decorrentes do seu uso normal; IV - levar imediatamente ao conhecimento do locador o surgimento de qualquer dano ou defeito cuja reparação a este incumba, bem como as eventuais turbações de terceiros; $V$ realizar a imediata reparação dos danos verificados no imóvel, ou nas suas instalações, provocados por si, seus dependentes, familiares, visitantes ou prepostos; VI - não modificar a forma interna ou externa do imóvel sem o consentimento prévio e por escrito do locador; VII - entregar imediatamente ao locador os documentos de cobrança de tributos e encargos condominiais, bem como qualquer intimação, multa ou exigência de autoridade pública, ainda que dirigida a ele, locatário; VIII - pagar as despesas de telefone e de consumo de força, luz e gás, água e esgoto; IX - permitir a vistoria do imóvel pelo locador ou por seu mandatário, mediante combinação prévia de dia e hora, bem como admitir que seja o mesmo visitado e examinado por terceiros, na hipótese prevista no art. 27. 
Quanto ao tempo de locação a ser contratado, é comum nos cortiços o acordo de aluguel com menos de 30 meses; nesse caso há uma semelhança com o modelo chamado de locação para temporada, previsto no artigo 48 da lei ${ }^{14}$. Esse modelo é muito utilizado nos casos de locação para residência temporária do locatário ou para prática de lazer, realização de cursos, tratamentos de saúde, feitura de obras em seu imóvel, e outras finalidades que requeiram tão-somente tempo determinado, e com prazo não superior a 90 dias.

Tema extremamente recorrente nas locações de cômodos de cortiços são os despejos que ocorrem em sua grande maioria de maneira forçada. Referente aos cortiços, a Lei do Inquilinato garante o despejo mediante o término do prazo de locação para temporada, no caso de haver possibilidade de enquadrar a locação nessa modalidade, além de constar a permanência do sublocatário no imóvel, uma vez extinta a locação, celebrada com o locatário.

A Lei do Inquilinato foi publicada no mesmo ano de publicação da Lei Moura. O dois instrumentos são de importância essencial para a manutenção da qualidade de vida nos cortiços.

14 "Artigo 48 da Lei do Inquilinato: Considera-se locação para temporada aquela destinada à residência temporária do locatário, para prática de lazer, realização de cursos, tratamentos de saúde, feitura de obras em seu imóvel, e outros fatos que decorram tão-somente de determinado tempo, e contratada por prazo não superior a noventa dias, esteja ou não mobiliado o imóvel. Parágrafo único: No caso de a locação envolver imóvel mobiliado, constará do contrato, obrigatoriamente, a descrição dos móveis e utensílios que o guarnecem, bem como o estado em que se encontram." 


\subsubsection{Lei no 11.228 de 1992 - Código de Obras e Edificações do Município de São Paulo}

O Código de Obras e Edificações do Município de São Paulo publicado em $1992^{15}$, um ano após a Lei Moura e a Lei do Inquilinato, por meio da Lei $n^{\circ} 11.228$, dispõe sobre as regras gerais e específicas a serem obedecidas no projeto, licenciamento, execução, manutenção e utilização de obras e edificações, dentro dos limites dos imóveis. Não há, na grande maioria de seus artigos, uma preocupação direta ou específica em relação aos cortiços.

No artigo $8^{\circ}$ da Lei $n^{0} 11.228$, em seu parágrafo único, fica definida a moradia econômica unifamiliar. De caráter popular, trata-se de uma habitação com área até $80 \mathrm{~m}^{2}$. Ficam isentas do pagamento de taxas e da comunicação de pequenas reformas, definidas no Código de Obras como aquelas que não apresentam supressão ou acréscimo de área, ou alterações que infrinjam as legislações edilícias e de parcelamento, uso e ocupação do solo independentemente de haver a mudança de uso do imóvel.

No entanto, presumem-se moradias econômicas aquelas cuja construção foi concebida através dos procedimentos formais de aprovação e de licença de funcionamento e que atende aos padrões do Código quanto às características construtivas e de uso bastante distintas das dos cortiços.

O dispositivo da lei que mais se aproxima das moradias que envolvem a população de extrema vulnerabilidade social se encontra no artigo 12, onde as exigências da lei ficam flexibilizadas em áreas sob intervenção urbanística promovidas pelo poder público e de programas habitacionais de interesse social, como urbanização de favelas e intervenção em cortiços e construções por mutirão.

Entretanto, no Capítulo 3 do Código de Obras fica claro que os cortiços não são considerados como categoria de uso, pois o alvará de licença é expedido somente para residências unifamiliares. O Capítulo 8 inicia com o seguinte texto:

\footnotetext{
${ }^{15}$ Em 1917 publica-se a Lei $n^{\circ} 956$ que reuniu vários decretos que já existiam de forma esparsa e que definiam padrões de licenciamento de construção e reforma. Em 1929 publica-se a Lei $n^{\circ} 3.427$ também denominada Código de Obras Arthur Saboya que antecede ao atual código de obras do município de São Paulo.
} 
"Para efeito das disposições constantes desta Lei, as edificações agrupar-se-ão conforme sua finalidade se assemelhar, no todo ou em parte, a uma ou mais das atividades aqui previstas".

No caso das habitações destinadas à moradia de caráter permanente, são classificadas em unifamiliar, multifamiliar ou coletiva, incluindo os seguintes tipos: casas, prédios de apartamentos, pensionatos, moradias de religiosos ou estudantes, orfanatos e asilos. Fica aí a dúvida se os cortiços podem ser considerados como semelhantes a pensionatos ou moradia de estudantes.

Quanto às habitações destinadas a usos como prestação de serviços de hospedagem ou moradia de caráter transitório incluem-se, entre outros, os seguintes tipos: hotéis, hotéis-residência e motéis; pensões, hospedarias e albergues. Novamente, fica a dúvida quanto à semelhança dos cortiços com essas categorias.

A discussão aqui é o tipo de repercussão que poderá causar na cidade a abertura de uma categoria de uso para cortiços. E, ainda, se há necessidade de instituir uma categoria exclusiva para cortiços quando se tem usos similares como os pensionatos, pensões, hospedarias e albergues. Evidentemente, a característica dos cortiços é diferente dos demais usos, principalmente no que se refere ao aspecto da lotação e da degradação dos ambientes; no entanto, permanece a dúvida se as péssimas condições de habitabilidade dos cortiços podem ser mais bem combatidas com uma fiscalização baseada na Lei Moura e em uma nova categoria de uso.

Em relação ao aspecto construtivo, é importante observar que o Código de Obras estabelece critérios para aberturas de aeração e insolação que foram seguidos pela lei que regulamenta cortiços. Especificamente, esse tema se mostra como parte crucial no ambiente insalubre desses imóveis. As aberturas são as mesmas previstas na Lei Moura. No item 11.2.2, o Código define $15 \%$ da área do compartimento destinada para a insolação, o que equivale a 1/7 da área de piso, como diz textualmente o artigo $3^{\circ}$ da Lei Moura. Da mesma forma, a metade dessa área deverá ser reservada para a aeração do compartimento.

Outro aspecto importante a ser observado é a lotação dos cortiços em relação ao mínimo exigido pelo Código de Obras. A lotação das edificações, no item 12.6, é definida como o número de usuários calculado na dependência de sua área e utilização. Para os usos habitacionais e prestação de serviço de hospedagem, o 
mínimo estabelecido pelo Código de Obras são 15 metros quadrados por pessoa. Nos cortiços temos uma média de 12 metros quadrados por pessoa (Relatório de Progresso, Habi-Centro, 2010), dividindo a área construída dos imóveis pela quantidade de moradores. A média é bem próxima das exigências do Código, o que nos induz a concluir que não deverá constituir grande desafio alcançar o disposto no Código.

\subsubsection{Resolução do Programa de Cortiços}

Em 7 de dezembro de 2004, é aprovada a Resolução $n^{\circ} 15$ do Conselho Municipal de Habitação de São Paulo $(\mathrm{CMH})$, que institui o Programa de Cortiços Reabilitação da Moradia Coletiva.

A resolução que institui o Programa é parte integrante das 52 resoluções do Conselho Municipal de Habitação que formalizam diversas definições dos conselheiros, entre autorizações de pagamentos, repasses e liberações de recursos financeiros para determinados programas, aprovações de prestação de contas, além de instituírem os diversos programas habitacionais operados pela Companhia Metropolitana de Habitação ${ }^{16}$, vinculados ao gabinete da Secretaria Municipal de Habitação da cidade de São Paulo.

A Resolução n 15, de certa forma, reforça ações já previstas na Lei Moura e na Lei do Inquilinato. De fato, utiliza as duas leis, entre outras, como respaldo jurídico para a instituição de suas diretrizes.

A Resolução $n^{0} 15$ traz considerações interessantes em relação à informalidade nos contratos de locação com consequências no agravamento da qualidade de vida dos moradores de cortiço e em relação à possibilidade de melhoria das condições de habitação por meio de reformas das edificações já existentes.

\footnotetext{
${ }^{16}$ Outros programas habitacionais instituídos por resoluções do Conselho Municipal de Habitação: Programa Carta de Crédito Municipal, Programa Bolsa Aluguel, Programa Parceria Social, Programa Locação Social, Locação para Moradia Provisória.
} 
Por outro lado, a resolução deixa claro em suas considerações a preocupação em proceder a uma operação de fiscalização baseada na aplicação da Lei Moura, uma vez que a ação poderia ocasionar a expulsão da população de moradores dos cortiços. Como medida preventiva, a Resolução sugere que linhas de financiamento poderiam evitar tal expulsão de moradores de $\operatorname{cortiços~}^{17}$.

O objetivo do Programa de Cortiços fica claro nas diretrizes estabelecidas, que visam à melhoria das condições de habitabilidade dos cortiços mediante a adequação aos padrões estabelecidos na Lei Moura.

Estabelece, como diretriz, que o Programa seja desenvolvido pela Sehab em parceria com a Comissão de Intervenção e Recuperação de Cortiços (CIRC), retirando, aparentemente, autonomia de uma ação que poderia ser meramente administrativa.

O Programa de Cortiços fica estruturado em três eixos. O primeiro trata da capacitação dos moradores de cortiços, que compreende o desenvolvimento de ações educativas visando contribuir para a construção da cidadania dos moradores.

O segundo eixo do Programa é a fiscalização e adequação dos imóveis encortiçados à Lei Moura. A Resolução recomenda que a CIRC gerencie as ações de fiscalização, a aplicação de multas e até a interdição dos imóveis.

Os procedimentos de fiscalização terão como objetivo incentivar o proprietário ou responsável pelo cortiço a realizar melhorias de adequação do cortiço aos padrões da lei, e, se estas não forem realizadas, serão impostas multas aos proprietários ou responsáveis pelo imóvel.

O terceiro eixo é a intervenção nos cortiços, que poderá ser feita das seguintes maneiras: a) em parceria com outras entidades públicas ou privadas; b) por meio de determinações ao proprietário, que realizará as melhorias necessárias com seus próprios recursos; c) por meio de determinações ao proprietário, que realizará as melhorias com financiamentos concedidos com recursos do Fundo Municipal de Habitação (FMH).

\footnotetext{
${ }^{17}$ Parte do texto da resolução $n^{\circ} 15$ : CONSIDERANDO que foi iniciado um processo de fiscalização gerenciado pela Comissão de Intervenção e Recuperação dos Cortiços (CIRC) e que o financiamento evitará a expulsão da população moradora nos imóveis atingidos.
} 
Importante frisar que se entendem por melhoria as pequenas reformas em que não há alteração da estrutura da edificação, tais como: pintura interna e externa; troca de revestimento; substituição e consertos em esquadrias e portas, sem modificação de vãos; troca de telhas ou elementos de cobertura; reparos em instalações elétricas e/ou hidráulicas. A reforma que envolver remoção de divisórias ou de mezaninos adaptados enquadra-se na definição de melhoria para os fins desta Resolução.

Para a realização da reformas, a Resolução prevê linhas de financiamento de recursos provenientes do Fundo Municipal de Habitação. Nesse caso, as exigências são mais restritivas que as determinadas pela Lei Moura; por exemplo, a quantidade de banheiros e tanques fica reduzida de 20 para dez.

Até março de 2011, não houve nenhum contrato de financiamento através do FMH para essas iniciativas.

\subsubsection{O Plano Municipal de Habitação de São Paulo e a Moradia Digna}

Um enorme desafio dos novos Prefeitos, especialmente nos Municípios que têm população acima de 20.000 habitantes, será promover o processo de elaboração e aprovação, até 2006, dos Planos Diretores Municipais. Trata-se de obrigação estipulada pela Constituição Federal de 1988 e regulamentada pelo Estatuto da Cidade de 2001 - mas, até hoje, pouquíssimos Municípios já o fizeram, ou começaram a debater a questão. Além de sérias consequências jurídicas do não-cumprimento dessa obrigação, para Municípios e Prefeitos, também da perspectiva da sociedade é crucial que tais Planos Diretores sejam amplamente discutidos e aprovados, para materialização dos princípios, instrumentos, direitos e obrigações estabelecidas pelo Estatuto da Cidade.

Lei federal aclamada internacionalmente, o Estatuto da Cidade foi uma conquista social que abriu caminhos para o enfrentamento da profunda crise urbana e habitacional do país. Dada a heterogeneidade de realidades locais, os princípios gerais da política urbana devem ser traduzidos em leis municipais - os Planos Diretores Municipais. Espera-se desses Planos Diretores que, em cada contexto local, promovam a materialização das 
quatro dimensões da lei federal, quais sejam: determinação de critérios para cumprimento da função socioambiental da propriedade (condições mesmo para o reconhecimento do direito de propriedade privada) na forma de uma proposta de ordenamento territorial e de uso, ocupação e desenvolvimento do solo que expresse um "projeto de cidade"; identificação dos instrumentos urbanísticos a serem utilizados para alcançar tal projeto de cidade; criação de mecanismos locais de regularização de assentamentos informais; e regulamentação dos processos municipais de gestão urbana participativa (Alfonsin, Fernandes, 2006, p 351)

O Plano Municipal de Habitação de São Paulo, em fase de elaboração, está vinculado ao Plano Diretor Estratégico do Município de São Paulo e apoia-se no arcabouço legal instaurado pela Constituição Federal, que estabelece o direito de todo cidadão brasileiro à moradia digna.

Os Planos são instrumentos de fundamental importância para a implantação de programas de regularização fundiária e de urbanização de assentamentos precários, ou ainda de destinação de imóveis desocupados ou subutilizados para a provisão habitacional de interesse social ${ }^{18}$.

O Plano Municipal de Habitação, que está em conformidade com o estabelecido pelo artigo $6^{\circ}$ do Plano Diretor Estratégico do Município de São Paulo Lei Municipal $n^{\circ} 13.430 / 2002$-, contempla propostas do poder público municipal para a política habitacional de interesse social para o período de 2009 a 2024 , correspondente a quatro quadriênios.

Além dos instrumentos jurídicos federais, o Plano adota as Metas do Milênio ${ }^{19}$ promulgadas pela ONU, das quais a Prefeitura do Município de São Paulo é

\footnotetext{
${ }^{18}$ A Habitação de Interesse Social é definida no inciso XIII do artigo 146 do Plano Diretor Estratégico como "aquela que se destina a famílias com renda igual ou inferior a 6 (seis) salários mínimos, de promoção pública ou a ela vinculada, com padrão de unidade habitacional com um sanitário, até uma vaga de garagem e área útil de no máximo $50 \mathrm{~m}^{2}$ (cinquenta metros quadrados), com possibilidade de ampliação quando as famílias beneficiadas estiverem envolvidas diretamente na produção das moradias."

${ }^{19}$ As oito Metas do Milênio foram lançadas em 2000 por diversas lideranças mundiais, reunidas na sede da ONU, com o objetivo de reduzir a pobreza no mundo. Podem ser acessadas no site www.un.org. A Meta 7 propõe assegurar sustentabilidade ambiental, através de 11 objetivos, dos quais dois se relacionam com as condições de moradia. O Objetivo 10 estabelece reduzir à metade $a$ proporção de pessoas no mundo sem acesso à água potável; e o Objetivo 11 propõe alcançar melhora significativa na vida de, no mínimo, 100 milhões de domicílios em assentamentos precários e informais do mundo até 2020. Esse objetivo deve ser medido através da proporção de pessoas com
} 
signatária. Entre as oito metas estabelecidas, os objetivos $10^{\circ}$ e $11^{\circ}$ da Meta 7 estão relacionados com a política habitacional da cidade, referente à implantação de saneamento e à garantia da segurança na posse para todos os assentamentos precários e informais do mundo.

O desenvolvimento do Plano é participativo e conta com o envolvimento de equipes técnicas da Superintendência de Habitação Popular e do Departamento de Regularização de Loteamentos, ambos da Secretaria Municipal de Habitação de São Paulo.

O conhecimento técnico acumulado por funcionários públicos efetivos, em geral com mais de 30 anos de experiência no funcionalismo público, tanto na área social quanto na de apoio jurídico à regularização fundiária, ou na de projetos e obras, foi fundamental para a formulação das críticas necessárias à revisão dos programas, à definição das metas e, sobretudo, ao conhecimento territorial que possibilitou a elaboração dos Planos de Ação Regional, com a definição dos perímetros de ação integrada e sua distribuição no horizonte temporal do Plano.

A participação da sociedade civil na formulação, implementação e acompanhamento da política habitacional se dá através das instâncias de participação, como o Conselho Municipal de Habitação, Conselhos Gestores de intervenções públicas em andamento em áreas definidas como Zonas Especiais de Interesse Social (ZEIS), dos Conselhos Gestores das Operações Urbanas vigentes no município e através de audiências públicas. ${ }^{20}$

A política habitacional apresentada no Plano se pauta por cinco princípios fundamentais: moradia digna, justiça social, sustentabilidade ambiental, gestão democrática e gestão eficiente.

Para efeito desta dissertação, daremos maior atenção ao princípio da moradia digna. O primeiro e fundamental princípio que rege a política municipal da habitação é o que assegura o direito à moradia digna enquanto direito social a todos os seus cidadãos, tal como estabelecido no artigo $6^{\circ}$ da Constituição Federal, pela Lei

segurança na posse e da proporção de pessoas com acesso a melhores condições de saneamento (água potável, esgotamento sanitário e demais redes de infraestrutura urbana).

20 Conselhos gestores podem ser bipartites ou tripartites sendo a sociedade civil representada por munícipes eleitos por meio de eleições diretas e voluntárias. 
Federal $n^{\circ}$ 10.257/2001 - Estatuto da Cidade - e pelo artigo 79 do Plano Diretor Estratégico (Lei Municipal n 13.430/02).

Esse arcabouço legislativo define moradia digna como aquela que

[...] garante ao morador a segurança na posse e dispõe de instalações sanitárias adequadas, com condições de habitabilidade, atendida por serviços públicos essenciais - abastecimento de água potável, esgotamento sanitário, energia elétrica, iluminação pública, coleta de lixo, pavimentação e transporte coletivo, além do acesso aos equipamentos sociais básicos.

A minuta do Plano estabelece duas linhas de ação segundo as quais a moradia digna será alcançada. Uma delas é a corretiva, que trata de ações de urbanização e regularização de diversos tipos de assentamentos precários e informais da cidade, caracterizando-se como atendimento à demanda em estado de inadequação habitacional. Aqui podemos considerar os cortiços como parte integrante dessa demanda. A outra linha de ação, a preventiva, trata da construção de alternativas para a produção habitacional para famílias de baixa renda e se caracteriza pelo atendimento ao déficit habitacional.

No que concerne aos cortiços, o breve diagnóstico da região central descrito no Plano traz informações da área representada pela Divisão Técnica Regional de Atendimento Habitacional - Centro (Habi-Centro) envolvendo quatro subprefeituras centrais da cidade: Sé, Mooca, Lapa e Pinheiros. Com uma população de 1.474 .565 habitantes $^{21}, 71.866$ vivem em assentamentos precários informais, equivalentes a $4,8 \%$ do total. Esse número abrange a população moradora em favelas e cortiços. De acordo com o Plano, o centro da cidade é a única região que, atualmente, apresenta dados precisos e recebe ação pública para os cortiços. Ainda assim, a área à qual se refere o Plano com dados precisos de cortiços é abrangida somente pelas subprefeituras Sé e Mooca.

Está sendo proposto, na minuta do Plano, a expansão do Programa de Cortiços para toda a cidade de São Paulo e a revisão da Lei Moura como atividades contempladas nos quadriênios vindouros.

\footnotetext{
${ }^{21}$ Censo de 2009 do IBGE.
} 


\subsection{Função social da propriedade e sustentabilidade urbana}

A cidadania, a dignidade da pessoa humana, os valores sociais do trabalho, lembrados no artigo $1^{\circ}$ da nossa Constituição, são indicados aí como fundamentos da República, entre outros. A construção de uma sociedade livre e solidária, a erradicação da pobreza, da marginalização, das desigualdades sociais, a promoção do bem de todos, sem preconceitos e quaisquer formas de discriminação, figuram também, entre outros, como objetivos dessa mesma República.

Essas simples lembranças, além de demonstrar que a função social da terra não só interessa diretamente a todas elas, são também condição de seus efeitos jurídicos concretos, como base física de todos os direitos humanos fundamentais das mesmas derivados. Isso é suficiente para provar o enorme prejuízo que causa a toda a nação e ao seu povo o uso da terra estritamente limitado às oportunidades e conjunturas do mercado, segundo o juízo exclusivo do seu proprietário (Alfonsín, Fernandes, 2006, p 180).

A pesquisa elaborada pela Seade, em 2009, inclui os cortiços da periferia localizados em loteamentos irregulares, em favelas, e ainda construções que se enquadram em uma classificação de inadequação não coincidente com a definição de cortiço pela Lei Moura, encontrando-se nessa condição um total de 127 mil domicílios. Desconsiderando os cortiços inseridos nesses assentamentos precários e as moradias em inadequação, ficamos com um total de 80 mil domicílios encortiçados na cidade de São Paulo.

Adotemos, para efeito desta dissertação, que cada domicílio abriga uma família. Logo, o número estimado de famílias moradoras em cortiços na cidade de São Paulo é de 80 mil, podendo chegar a 140 mil habitantes, representando 1,27\% da população total da cidade habitando em cortiços.

Também para efeito desta dissertação adotemos a área média de 12 metros quadrados por cômodo/família encontrada nos cortiços do centro da cidade (Relatório de Progresso/Habi-Centro, 2010). Logo, concluímos que a área construída utilizada pela população em cortiços representa $0,23 \%$ do total da cidade. Ou seja, 
em se tratando de cortiços temos $1,27 \%$ da população de São Paulo habitando em $0,23 \%$ do espaço total construído.

Ao que parece, 0,23\% desse ambiente construído poderia ser facilmente equacionado através da implementação das premissas da função social da propriedade imóvel. De outra maneira, fazendo uso do raciocínio inverso, pode-se se afirmar que não teria sido contextualizada a função social do imóvel se não fosse para atender a uma necessidade em larga escala, ou seja, a abrangência desse poderoso instrumento urbanístico abarcaria uma porção bastante significativa, muito maior do que o exíguo $0,23 \%$ do espaço total construído.

Para o centro da cidade de São Paulo, onde os dados são precisos, temos em março de 2010 uma população moradora em cortiços de aproximadamente 19.900 pessoas (Costa, França e López. 2010), o que representa 2,3\% dos habitantes das subprefeituras centrais Sé e Mooca. Em relação aos moradores em cortiços na cidade, a população em cortiços no centro representa $19 \%$ do total.

Os números percentuais são baixos; porém, o contingente populacional é alto. No entanto, a ocorrência de cortiços tem diminuído à razão de 8,31\% de 1994 para 1997 (FIPE, 1997), 74,9\% de 1997 para 2001 e 29,21\% de 2001 para 2005 (Costa, França e López, 2010).

Aparentemente, caminha-se para a extinção do cortiço na área central da cidade; porém, o fim desse modelo de ocupação pode representar o fim do acesso à moradia para a população pobre na área central da cidade, pelo fluxo natural do mercado, o que não é necessariamente positivo para o alcance de uma sustentabilidade urbana para uma metrópole como São Paulo.

A sustentabilidade social e urbana permeia conceitos de centralidade não só sob a ótica das camadas sociais mais abastadas, mas também das camadas médias ou pobres, sendo o acesso à moradia definitivamente um dos principais promotores do desenvolvimento da diversidade social, pois tem o poder de fixar em um mesmo território, públicos diversos, forçando o desenvolvimento de relações de vizinhança.

Sob essa perspectiva, a erradicação desse tipo de imóveis das áreas centrais, ou do perímetro urbano da cidade, não se configura como solução sustentável. Sua recuperação, sim. Podemos considerar que, para uma cidade como São Paulo, a linha de ação corretiva da moradia digna, segundo minuta do Plano Municipal de 
Habitação, direcionada para exíguo $0,23 \%$ dos espaços construídos, deveria se configurar como atividade permanente.

Outro ponto de vista defensável vincula-se à linha de ação preventiva da moradia digna, definida como aquela que combate 0 déficit habitacional. Considerando o déficit habitacional representado pela população em cortiços, não deverá constituir grande desafio a provisão de moradia digna para $1,27 \%$ da população. Mais uma vez, o percentual é baixo; porém, significa a construção de 80 mil moradias populares.

Se a sustentabilidade urbana está para a linha de ação corretiva da moradia digna, a função social da propriedade está para a linha preventiva da moradia digna. Em ambos os casos, qualquer operação de cunho imobiliário, derivada dos dois conceitos, remete ao tema da densidade urbana ou a sua distribuição pela cidade.

\subsubsection{Densidade}

A densidade de uma cidade é um parâmetro utilizado por urbanistas para diagnosticar e desenvolver planejamentos e projetos urbanos. Ter governabilidade sobre a densidade significa promover transformações substanciais na dinâmica econômica e social de uma determinada região ou cidade. Quanto à sustentabilidade, formas urbanas somente podem ser consideradas sustentáveis se forem entendidas, pelos seus moradores, como lugares para viver, trabalhar e interagir, ou, ainda, se suas comunidades ou vizinhanças forem estáveis ou funcionais (Bramley G. et al, 2009, p 2125).

Dos elementos da forma urbana que devem ser analisados, a densidade é o que tem recebido maior atenção no que se refere ao impacto social (Bramley G. et al, 2009, 2127). A densidade é normalmente medida em pessoas por hectares e expressa a razão entre a quantidade de pessoas pela área de projeção das edificações, independentemente de seu uso. A quantidade de área de superfície a ocupar, determinada por legislações que impliquem zoneamento, processos 
migratórios e imigratórios, além do crescimento vegetativo da cidade, está associada a alterações da densidade urbana.

Intrínseca à ocupação de superfície, a quantidade de área construída e por construir, regrada por zoneamento e outros instrumentos urbanísticos, irá definir a intensidade da concentração de pessoas por tipo de atividade. Em São Paulo, a densidade media é de $10 \mathrm{mil}$ hab $/ \mathrm{km}^{2}$, variando de $477 \mathrm{hab} / \mathrm{km}^{2}$, no caso da Subprefeitura de Parelheiros, a 16 mil hab $/ \mathrm{km}^{2}$, no caso da Subprefeitura de Cidade Tiradentes $^{22}$. Quanto à concentração de usos, observamos que na região central da cidade há 1.000 empregos por hectare, contra 25 na periferia da Zona Leste da cidade (Figura 1).

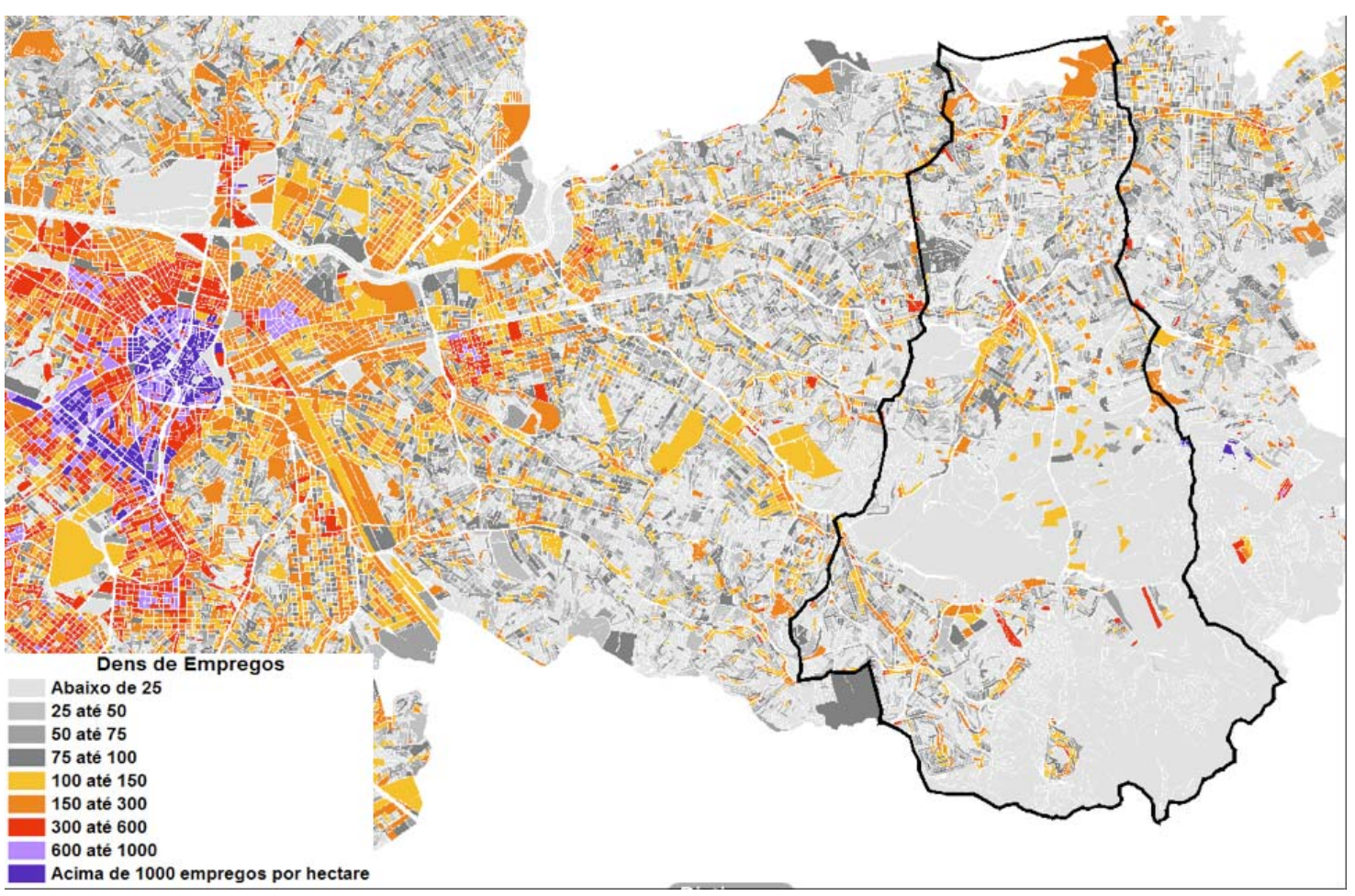

Figura 1 - Fonte: Documentação Operação Urbana Rio Verde-Jacu - Secretaria Municipal de Desenvolvimento Urbano (SMDU).

Temos aí uma densidade de empregos heterogênea, com apenas uma grande concentração de empregos, e uma densidade residencial homogênea que tende para a insustentabilidade, se considerarmos Yiftachel e Hedgcock (1993, p. 140), que definem sustentabilidade social urbana como a contínua habilidade de uma cidade se manter funcional a longo prazo, viabilizando a interação humana, a comunicação e o desenvolvimento cultural. 
No caso dos cortiços, a prefeitura tem dados precisos somente em relação ao centro da cidade, referentes às subprefeituras Sé e Mooca ${ }^{23}$.

Nas duas subprefeituras centrais da cidade, Sé e Mooca, segundo Relatório de Progresso ${ }^{24}$ da Habi-Centro ${ }^{25}$, cujo fechamento é março de 2010, há 1.091 imóveis encortiçados que, juntos, somam $220.279 \mathrm{~m}^{2}$ de área de terreno, ou 0,22 $\mathrm{km}^{2}$, que representam $0,39 \%$ da soma das áreas das duas subprefeituras, com uma população arrolada, entre 2005 e 2010, de 19.900 habitantes.

Na hipótese de termos $1 \mathrm{~km}^{2}$ de área de terreno de cortiços, obteremos uma densidade de 71.318 habitantes por $\mathrm{km}^{2}$. Vemos que a densidade nos cortiços pode alcançar até dez vezes a densidade média da cidade de São Paulo.

A procura por aluguéis de imóveis encortiçados na área central da cidade pode ter explicação na alta concentração de empregos, como demonstra a Figura 1.

Ao contrário da leitura recorrente de que nas últimas décadas houve um esvaziamento populacional no centro de São Paulo - o que é fato -, a densidade na Subprefeitura da Sé (12.845 hab/ $\mathrm{km}^{2}$ ) é maior que em muitos distritos de periferia e de outros bairros nobres da cidade, indicando que o referido esvaziamento populacional não foi o bastante para promover a diminuição da densidade no centro, nem populacional nem, tampouco, de oferta de emprego.

\footnotetext{
${ }^{23}$ A Prefeitura Municipal de São Paulo tem uma divisão administrativa e fiscal de 31 subprefeituras, sendo a maior e mais complexa delas a Subprefeitura da Sé.

${ }^{24}$ O Relatório de Progresso contém dados estatísticos e gerenciais das atividades do Programa de Cortiços que ocorrem nas subprefeituras da Sé e Mooca desde novembro de 2005.

${ }^{25}$ A Divisão Técnica Regional de Atendimento Habitacional - Centro (Habi-Centro) é uma das nove diretorias que compõem a Superintendência da Habitação Popular da Secretaria Municipal de Habitação.
} 


\subsubsection{Vacância no mercado residencial formal na área central de São Paulo}

Não obstante o fato de $76 \%$ dos cortiços não apresentarem conformidade em relação ao artigo $3^{\circ}$ da Lei $10.928^{26}$, os cômodos são locados em média a $R \$ 21 / \mathrm{m}^{2}$.

O mercado formal da locação residencial não comporta unidades tão pequenas como os cômodos dos cortiços, que em média têm $12 \mathrm{~m}^{2}$ de área. $\mathrm{O}$ menor produto praticado pelo mercado imobiliário, à exceção de unidades habitacionais do mercado hoteleiro, são as quitinetes, que em geral têm entre $28 \mathrm{e}$ $38 \mathrm{~m}^{2}$ de área.

A procura pelo cômodo do cortiço, em detrimento da procura pela quitinete, se dá em parte pelo fato de a população de baixa renda não atender à formalidade exigida pelas práticas do mercado imobiliário. Outro fator é a faixa de um a três salários mínimos de renda familiar, na qual se enquadra $77 \%$ dessa população. Desse modo, o cômodo de cortiço se mostra mais acessível para os mais pobres do que as ofertas do mercado formal.

Outro fator importante no mercado de locação residencial é a pouca vacância na área central. Estudos de mercado de locação residencial realizados em 2002, por ocasião da implementação do Programa de Locação Social da Superintendência de Habitação Popular/Sehab, demonstraram uma vacância baixa no mercado formal da locação residencial. O estudo analisou 1.500 imóveis de um universo total de 250 mil existentes abrangendo os distritos centrais de São Paulo.

De acordo com Rottman (2004), apenas 9\% dos imóveis residenciais estão vagos e ainda $25 \%$ deles correspondem a quitinetes - produto que mais se aproxima em área a um cômodo de cortiço -, ou seja, $75 \%$ desses imóveis vagos estão realmente fora do alcance do perfil socioeconômico da população moradora em cortiços.

Se não há oferta no mercado formal para o público de baixa renda, talvez a única solução esteja realmente na locação de cômodos de imóveis encortiçados. Em

${ }^{26} \mathrm{O}$ artigo $3^{\circ}$ da Lei Moura ( $\mathrm{n}^{\circ}$ 10.928/91) estabelece parâmetros mínimos de habitabilidade em cortiços para o município de São Paulo. 
outras palavras, a moradia coletiva informal contribui de fato para a permanência dessa população na área central.

A dinâmica do mercado, seja ele qual for, indica que quanto menor a vacância, ou oferta, maior o preço do produto. Essa relação mercadológica, amplamente difundida, pode parecer incompatível com conceitos da função social do imóvel. Vejamos: quanto maior a vacância/oferta, maior desconformidade com a função social do imóvel pois sugere subutilização porém, minora o preço e aumenta a acessibilidade da demanda.

Por outro lado, quanto menor a vacância/oferta, maior otimização de recursos e serviços públicos, atentando para preceitos de sustentabilidade urbana; porém, majora o preço do produto e diminui a acessibilidade da demanda, principalmente a carente e socialmente vulnerável.

Concentremo-nos no distrito Sé, da Subprefeitura da Sé localizado na área central da cidade de São Paulo delimitado pelas avenidas Prestes Maia e à continuação pela avenida 23 de maio à oeste, do Estado à leste, acesso ao elevado Costa e Silva ao sul e rua Mauá ao norte conforme Figura 2. 


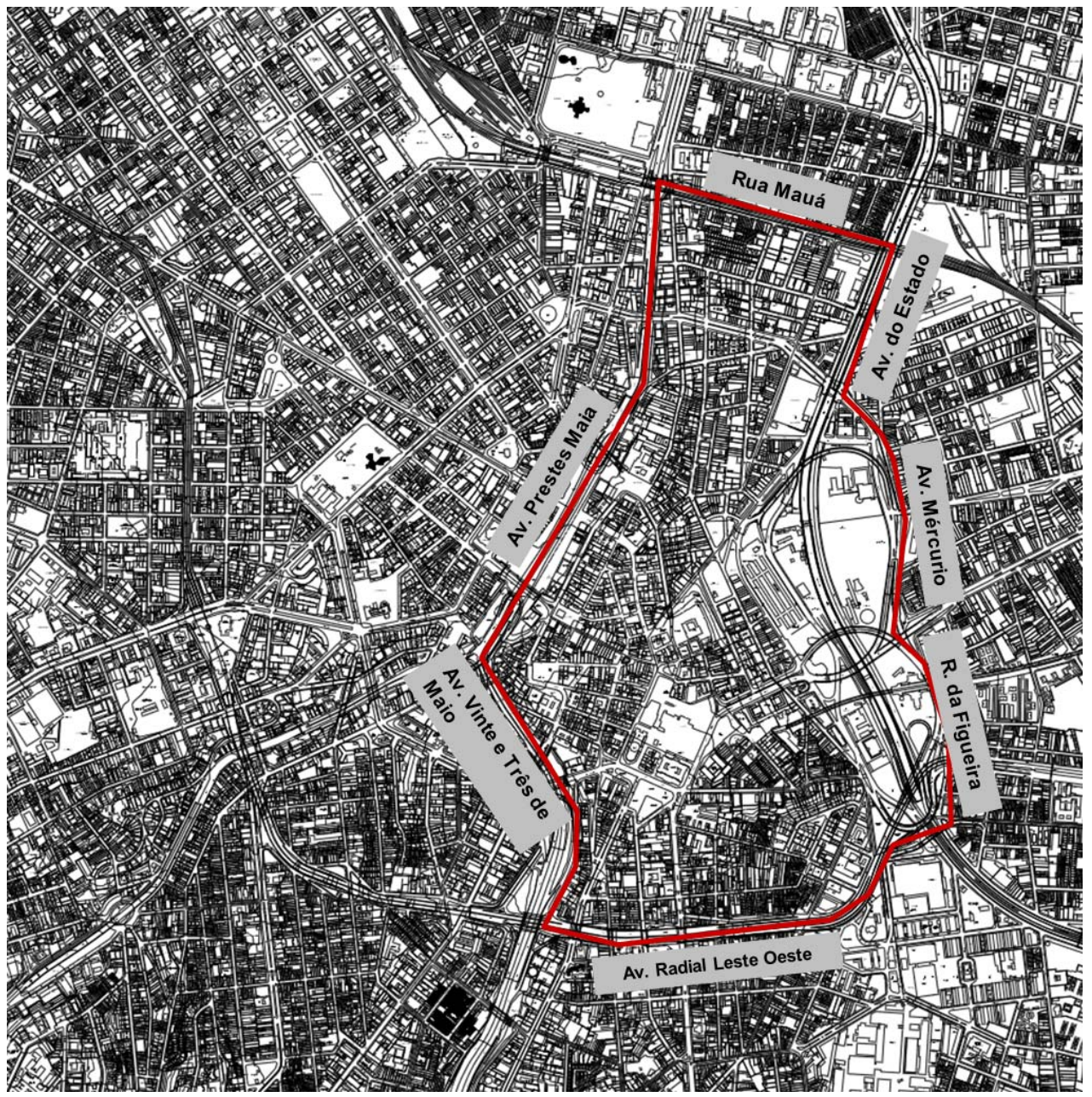

Figura 2 - Subdistrito Sé - Subprefeitura da Sé.

O distrito é predominantemente comercial e de serviços. No entanto, em levantamento realizado pela Habi-Centro, dos aproximados 6 mil lotes do distrito, 208 edifícios encontravam-se, em novembro de 2009, desocupados. Destes, 90\% têm fração ideal ${ }^{27} 1,00$, e $40 \%$ são de uso residencial.

Os imóveis desocupados representam apenas 3\% do total de imóveis do distrito, o que nos induz a concluir que a pouca oferta habitacional, inclusive para um público de baixa renda, está na falta da exploração do coeficiente máximo construtivo dos terrenos ou na falta de estoque residencial. Decorre daí uma realidade que deixa patente conceitos de sustentabilidade urbana e da função social da propriedade, ao mesmo tempo que os funde.

${ }^{27}$ Fração ideal é a parte indivisível e indeterminável das áreas comuns e de terreno, proporcional à unidade autônoma de cada condômino. Quando a construção tem fração ideal 1, significa que pertence a apenas um proprietário. 


\subsection{Objetivo da dissertação}

Nas últimas décadas, o papel do Estado na oferta de serviços e bens em geral, e da habitação em particular, tem sofrido profundas alterações. Há uma tendência clara de se reduzir a intervenção direta dos agentes públicos no processo de provisão, de se estimular a participação de agentes não-públicos, tais como o setor privado, as ONGs (organizações não governamentais, que têm um caráter voluntarista), e as próprias comunidades que recebem os serviços/bens, no caso, a habitação, bem como tem havido um esforço por parte desses agentes neste mesmo sentido. Essa tendência é, sem dúvida, global, e o Brasil não constitui uma exceção [...] o crescente envolvimento de agentes não-públicos na oferta de habitação e outros bens/serviços não significa que os agentes públicos (isto é, o Estado) devem ou irão desaparecer. O que está acontecendo é uma mudança efetiva no papel do Estado, que deixa de ser de apoio e passa a ser de facilitação [...] Além disso, do mecanismo de oferta de habitação ou outros bens/serviços participam elementos diversos, como: planejamento, financiamento, gestão, produção propriamente dita, monitoramento e fiscalização. A maneira pela qual esses elementos serão distribuídos entre os agentes públicos e não-públicos irá definir o padrão geral da oferta (Werna, Abiko et al. 2001, p 18).

O objetivo desta dissertação é relatar as atividades do Programa de Cortiços da Prefeitura do Município de São Paulo no período de 2005 a 2010.

Como vimos, de acordo com Werna, Abiko et al. (2001), o mecanismo de oferta de habitação é a somatória de elementos diversos, e sendo o papel do Estado o de facilitador, as atividades do Programa de Cortiços podem ser entendidas como modelo de bens/serviços habitacionais por estarem baseadas em uma extensa programação de fiscalização dos imóveis encortiçados do centro da cidade de São Paulo.

O respaldo jurídico para essas fiscalizações, que por sua vez sustentam o Programa de Cortiços, se compõe de instrumentos antigos e nunca antes postos em prática. 
A Lei Municipal $n^{\circ} 10.928$ foi publicada em 1991; seu Decreto Regulamentador $n^{\circ} 33.189$ foi publicado no mesmo ano; e a Resolução $n^{\circ} 15$ do Conselho Municipal de Habitação $(\mathrm{CMH})$ de São Paulo, que instituiu o Programa de Cortiços, foi aprovada em 2004. No entanto, foi somente em 2005 que se iniciou de fato um trabalho nos cortiços da cidade que executa o estabelecido por tais instrumentos.

É objetivo desta dissertação, relatar a aplicação desses instrumentos jurídicos que requereram amplo planejamento para a implementação das ações vinculadas à aplicação da legislação incidente nesses imóveis encortiçados, assim como também relatar a operacionalização do Programa de Cortiços, cujo projeto de implementação deveria seguir rigorosamente a regulamentação da Resolução do Programa de Cortiços.

A Divisão Técnica Regional de Atendimento Habitacional Centro (HabiCentro), da Superintendência de Habitação Popular (Habi), até 2005, detinha poucas informações referentes a cortiços e a sua população moradora. Não eram conhecidas questões socioeconômicas importantes, como, por exemplo, o percentual de crianças ou de idosos moradores nos cortiços, características da composição familiar, informações sobre a renda das famílias, tempo de moradia na área central ou a rotatividade nos cortiços.

Outra lacuna no conhecimento essencial para a formatação de um trabalho direcionado à melhoria de qualidade habitacional desses cortiços era o tipo de relação predominante entre o sublocador responsável pelo cortiço e as famílias locatárias, e a relação destas com o proprietário dos imóveis.

Não havia informações referentes à quantidade de imóveis invadidos em meio aos edifícios de apartamentos ou casas unifamiliares degradadas, hotéis insalubres usados como moradia, pensões, quartos de aluguel, "vagas para rapazes", repúblicas de estudantes; enfim, usos passíveis de serem denominados como cortiço segundo as impressões do senso comum, porém, pela definição da lei, não enquadráveis nessa categoria. Não havia informações acerca da tipologia predominante de imóveis utilizados como cortiços.

À época, em janeiro de 2005, o único material existente na Habi-Centro era a pesquisa amostral sobre cortiços na cidade de São Paulo, realizada pela FIPE, em 
1994, apontando uma população de 595.110 famílias em cortiços. Outro documento era o mapeamento de cortiços da Companhia de Desenvolvimento Habitacional e Urbano (CDHU) encomendado à Seade, realizado em 2002, com um total de 1.648 endereços de cortiços nos territórios das subprefeituras da Sé e Mooca.

Outro material disponível era proveniente de um programa denominado Programa de Rehabilitação Integrada do Habitat (PRIH), desenvolvido no período de 2001 a 2004, que realizou um levantamento de cortiços em um perímetro definido na região da Luz, entre as ruas João Teodoro e Mauá e as avenidas do Estado e Tiradentes.

O Programa definia ações de recuperação dos espaços públicos, "empoderamento" (tradução literal do inglês: empowerment) dos moradores de cortiços, recuperação de cortiços e realização de Empreendimento de Habitação de Interesse Social (EHIS) na Rua 25 de Janeiro, com cerca de 200 unidades habitacionais. No entanto, apenas um imóvel encortiçado foi recuperado na Rua Djalma Dutra, beneficiando 13 famílias, e o empreendimento de interesse social não atendeu especificamente a população dos cortiços, sendo ofertado para um público de renda superior à renda da população moradora nos cortiços da região.

Em relação aos cortiços, as ações da Prefeitura do Município de São Paulo haviam sido bastante pontuais e rarefeitas no território central da cidade. Diante de uma população estimada em 38 mil habitantes, aspiravam-se resultados em larga escala, pelo que a amplitude das ações desejadas para a melhoria da qualidade de vida desses usuários de cortiços começou a ser formulada em 2005.

Esta dissertação relata o desenvolvimento do projeto de implementação do Programa de Cortiços do poder público municipal, sua operacionalização e os resultados obtidos em cinco anos de experiência de uma equipe intersecretarial, envolvendo o poder público municipal e estadual, que alcançou um volume de intervenções em larga escala. 


\section{Relato das atividades do Programa de Cortiços da Prefeitura do Município de São Paulo}

A Prefeitura do Município de São Paulo instituiu o Programa de Cortiços por meio da Resolução $\mathrm{n}^{\circ} 15$ do $\mathrm{CMH}$, publicada no ano de 2004. Por sua vez, a Companhia de Desenvolvimento Habitacional e Urbano (CDHU), vinculada à Secretaria de Habitação do governo do Estado de São Paulo, mantém o Programa de Ação em Cortiços desde 2000. Através de um protocolo de intenções assinado em 2002, os dois órgãos estabeleceram uma parceira de trabalho que ganhou intensidade a partir de 2005, com o início da aplicação da Lei Moura por parte do poder público municipal.

O escopo do programa das duas instâncias de poder é diferente. A CDHU tem como principal atividade a construção de unidades habitacionais que se dão na área central da cidade e a concessão de cartas de crédito para compra de imóveis. A Superintendência de Habitação Popular tem como principal atividade a fiscalização dos imóveis encortiçados. O atendimento habitacional prestado às famílias moradoras em cortiços é uma combinação dos atendimentos dos dois órgãos.

A distribuição de tarefas das duas instâncias de poder se dá de acordo com o tipo de atendimento, e o planejamento da parceria atende às particularidades de cada atuação. No caso do poder público municipal, a fiscalização promove obras de reforma nos imóveis e, a depender das condições de habitabilidade, executa a interdição do imóvel. A saída das famílias desses imóveis com intervenção possíveis desadensamentos por reforma ou remoção total por risco - culmina nos atendimentos habitacionais da CDHU.

Outra parceria que se desenvolve no âmbito do Programa é intersecretarial. No poder público municipal, o órgão competente pela fiscalização é a Secretaria Municipal de Coordenação de Subprefeituras. Muito embora o Programa de Cortiços seja de responsabilidade da Secretaria Municipal de Habitação, as fiscalizações são realizadas pelas subprefeituras, mais precisamente as subprefeituras Mooca e Sé, onde se deram as primeiras fiscalizações de cortiços do Programa. 
Embora o Programa de Cortiços não se viabilize sem a participação ativa das subprefeituras no intenso trabalho das fiscalizações, o planejamento estratégico do Programa foi desenvolvido na Superintendência de Habitação Popular (Habi) da Secretaria Municipal de Habitação.

Os diversos programas de Habi, tais como Urbanização de Favelas, Regularização Fundiária, Revitalização, Reforma e Recuperação de Créditos do Prover $^{28}$, entre outros, têm sua gestão definida matricialmente, posto que os programas se desenvolvem no município todo.

Internamente, a Superintendência de Habitação Popular é composta por nove divisões: Habi-Planejamento, Habi-Obras e Projetos, Habi-Financeiro, Habi-Social e cinco divisões regionais de atendimento habitacional: Habi-Centro, Habi-Leste, HabiNorte, Habi-Sul e Habi-Sudeste.

O planejamento estratégico dos programas habitacionais envolve a participação de todas as Habi's. No caso específico do Programa de Cortiços, o planejamento, os objetivos do Programa, a determinação de resultados esperados e os indicadores de monitoramento das ações foram definidos para atuar inicialmente como piloto na região da Subprefeitura da Mooca. Sendo assim, a equipe envolvida nesse processo foi constituída predominantemente por técnicos de Habi-Centro e da Subprefeitura da Mooca.

\footnotetext{
${ }^{28}$ Programa de Verticalização iniciado em 1996, conhecido como Cingapura.
} 


\subsection{Objetivo do Programa de Cortiços - Quadro Lógico do Projeto}

Embora a própria lei que dispõe sobre qualidade habitacional em cortiços estabeleça em seu caput o objetivo daquela instrumentação e embora a Resolução $n^{\circ} 15$ do Conselho Municipal de Habitação, da mesma forma, estabeleça as diretrizes do Programa de Cortiços da Secretaria Municipal de Habitação, as ações do programa, precisavam de um projeto, ou estratégia para ser implementado, ou seja, precisava ser operacionalizado.

Evidentemente, o projeto que define as estratégias de implementação do Programa, deveria ser guiado e amparado por objetivos e diretrizes predefinidos nos instrumentos legais vigentes.

Contudo, para estabelecer uma perfeita sintonia entre as equipes intersecretariais que executam o programa, a Superintendência de Habitação Popular utilizou instrumentos de planificação de projetos de forma a obter uma gestão centrada em resultados a qual entende-se como uma estratégia de gestão na qual uma determinada organização orienta seus processos, produtos e serviços para a obtenção de resultados claramente definidos (PNUD, 2002).

Em especial o "Método Quadro Lógico" (do inglês: Logical Framework Analysis) foi aplicado para o estabelecimento de um padrão de objetivos, análise, apreciação, monitoramento e avaliação do projeto.

O Logical Framework Analysis (LFA), ou Método Quadro Lógico (MQL), é uma ferramenta de planejamento que tem sido profundamente utilizada por profissionais de planejamento, especificamente em projetos, programas e organizações que recebem fundos multilaterais, bilaterais e ONGs, configurando-se como uma ferramenta standard para planejamento, monitoramento e avaliação.

O método exige a definição de um Objetivo Superior do projeto, que deve ser discutido e definido em equipe. Em geral, o Objetivo Superior é genérico e abrangente. Em seguida, é necessário definir um Objetivo Específico do projeto, que deve ser debatido em equipe, de preferência pela equipe que irá executar a gestão do projeto. O método exige ainda a definição de atividades que levarão à consecução dos objetivos, assim como resultados esperados pelo projeto. 
Para as atividades e os resultados, são atribuídos indicadores de monitoramento e pressupostos segundo os quais o projeto deveria alcançar o objetivo.

Segundo o Quadro Lógico desenvolvido pela equipe, figura como Objetivo Superior a política habitacional municipal, como meta principal a ser alcançada. $O$ que faz sentido, se considerarmos que quaisquer atividades ou ações planejadas pelos diversos departamentos da Secretaria de Habitação deveriam apresentar um alinhamento com as diretrizes da política habitacional corrente no município.

O Objetivo Específico do Programa de Cortiços foi definido como: moradias multifamiliares com condições adequadas de habitabilidade e segurança jurídica.

Os resultados esperados do Quadro Lógico do Programa de Cortiços são 16, conforme quadro a seguir:

Tabela 2 - Resultados do Quadro Lógico do Programa de Cortiços

\begin{tabular}{|r|l|}
\hline 1 & proprietários ou responsáveis intimados \\
\hline 2 & imóveis vistoriados \\
\hline 3 & familias arroladas \\
\hline 4 & imóveis classificados por faixa de prioridade de intervenção \\
\hline 5 & uso definido do imóvel \\
\hline 6 & documentação requerida e recebida \\
\hline 7 & obra nos imóveis acompanhadas e concluídas \\
\hline 8 & imóveis informados à CDHU \\
\hline 9 & familias atendidas pela CDHU \\
\hline 10 & moradores e proprietários informados sobre seus direitos e deveres \\
\hline 11 & novos comportamentos estabelecidos (boa vizinhança e manutenção do imóvel) \\
\hline 12 & imóveis fiscalizados \\
\hline 13 & imóveis certificados \\
\hline 14 & imóveis interditados e lacrados \\
\hline 15 & projetos elaborados \\
\hline 16 & parcerias estabelecidas \\
\hline Fonte: 1 - Quadro lógico Programa de Cortiços. Documento de consultoria, 2008. \\
\hline
\end{tabular}

Para cada resultado, os indicadores utilizados para o monitoramento das ações estão estabelecidos na Lei Moura. Como pressupostos para o alcance dos resultados, o Quadro Lógico do Programa sugere que não deveria haver grande rotatividade das famílias, pois isso pode dificultar que condições de segurança de posse perdurem. Da mesma forma, não poderia haver grande quantidade de 
estrangeiros em situação ilegal, pois estes não poderiam ser atendidos pela CDHU nem assinar contratos em geral.

O proprietário, responsável, intermediário ${ }^{29}$ e inquilinos deveriam perceber a utilidade/importância na aplicação do regulamento interno ${ }^{30}$, e também zelar pela manutenção do imóvel.

As diversas atividades do Programa de Cortiços também são definidas no Quadro Lógico. Para cada resultado, há uma atividade específica em que os indicadores têm maior destaque. Dessa maneira, ao resultado "Proprietários/responsáveis intimados" corresponde uma atividade de fiscalização, definida no Quadro Lógico, como no quadro a seguir:

Tabela 3 - Atividades do Quadro Lógico do Programa de Cortiços

\begin{tabular}{|c|c|c|}
\hline & & INDICADORES \\
\hline & Intimar todos os proprietários/responsáveis dos imóveis caracterizados como objeto do Programa & $\%$ de intimações lavradas \\
\hline 2 & Vistoriar os imóveis do banco de dados & $\%$ de vistorias feitas \\
\hline 3 & Arrolar as familias do universo de possíveis beneficiários do Programa & $\%$ de arrolamentos feitos \\
\hline 4 & Classificar os imóveis para atuar de acordo com prioridade de intervenção e porte & \% de imóveis em adequação por faixa de prioridade \\
\hline 5 & Definir o uso do imóvel com o proprietário: interditar, certificar, mudar o uso ou reformar & $\begin{array}{l}\text { \% de imóveis por tipo de uso definido sobre o } \\
\text { universo de proprietários que se apresentaram e } \\
\text { sobre o universo total de intimados }\end{array}$ \\
\hline 6 & Requerer documentação dos proprietários em função do uso definido e receber os documentos & $\begin{array}{l}\text { \% de proprietários que entregaram documentação, } \\
\text { por opção feita }\end{array}$ \\
\hline 7 & Acompanhar as obras de adequação ou mudança de uso & $\%$ de imóveis por faixa de andamento da obra \\
\hline 8 & Enviar lista dos imóveis à CDHU & \% de imóveis informados à CDHU \\
\hline \multirow{4}{*}{$\frac{11}{12}$} & \multirow{4}{*}{$\begin{array}{l}\text { Conhecer o histórico do local e informar moradores e proprietários sobre o processo pelo qual } \\
\text { passam, e sobre seus direitos e deveres como: contrato de locação, regulamento interno; operar } \\
\text { transformação de comportamento }\end{array}$} & $\begin{array}{l}\text { \% de reuniões feitas e \% de moradores presentes, } \\
\text { por imóvel }\end{array}$ \\
\hline & & $\begin{array}{l}\text { Número de reuniões especificas feitas por imóvel e } \\
\% \text { de moradores presentes por imóvel }\end{array}$ \\
\hline & & $\begin{array}{l}\text { Número de reuniões de reforço de práticas e \% de } \\
\text { moradores presentes por imóvel }\end{array}$ \\
\hline & & Atividades de parcerias realizadas \\
\hline & $\begin{array}{l}\text { Fiscalizar, a cada dois anos, se o imóvel cumpre as exigências para ser certificado de acordo com } \\
\text { a Lei Moura }\end{array}$ & $\begin{array}{l}\text { \% de imóveis certificados que se mantém em } \\
\text { conformidade com a Lei }\end{array}$ \\
\hline \multirow[t]{2}{*}{14} & \multirow[t]{2}{*}{ Solicitar a interdição dos imóveis que não se adequaram e conferir a lacração } & $\%$ de imóveis certificados do total de cortiços \\
\hline & & $\begin{array}{l}\text { \% de imóveis cuja lacração foi acompanhada, sobre } \\
\text { o universo de imóveis notificados }\end{array}$ \\
\hline & Propor projetos de revisão da Lei & Projetos elaborados \\
\hline & $\begin{array}{l}\text { Fazer parcerias com outros órgãos para além dos objetivos do programa com benefícios para a } \\
\text { população-alvo }\end{array}$ & $\begin{array}{l}\text { Número de parcerias estabelecidas e escopo de } \\
\text { cada uma }\end{array}$ \\
\hline
\end{tabular}

Fonte: 2- Quadro lógico Programa de Cortiços. Documento de consultoria, 2008.

Da mesma forma que para os resultados do Programa, o Quadro Lógico define pressupostos para que as atividades possam se desenvolver de acordo com o planejado. Esses pressupostos ou condições para que as atividades sejam realizadas são: 1. A subprefeitura precisa priorizar a intimação, fiscalização e lacração de imóveis; 2. O proprietário precisa se apresentar e decidir em tempo hábil o uso que vai dar para o imóvel; 3. O proprietário precisa enviar os documentos em

\footnotetext{
${ }^{29} \mathrm{Na}$ Lei Federal do Inquilinato, o intermediário é qualificado como sublocador.

${ }^{30}$ Regulamento interno são as normas de convivência no cortiço. Equivale às regras condominiais.
} 
tempo hábil; 4. A CDHU precisa prover habitação, ajuda de custo ou carta de crédito para as famílias; e 5. A CIRC precisa referendar a certificação.

De acordo com o Quadro Lógico, a realização das atividades elencadas e monitoradas através de indicadores levaria aos resultados esperados pelo projeto; estes, por sua vez, conduziriam ao objetivo específico do Programa. Entretanto, não fica explícito no Quadro Lógico uma meta comum entre os técnicos da equipe de gestão do Programa. Almejava-se obter, em larga escala, os objetivos do Programa de Cortiços. 


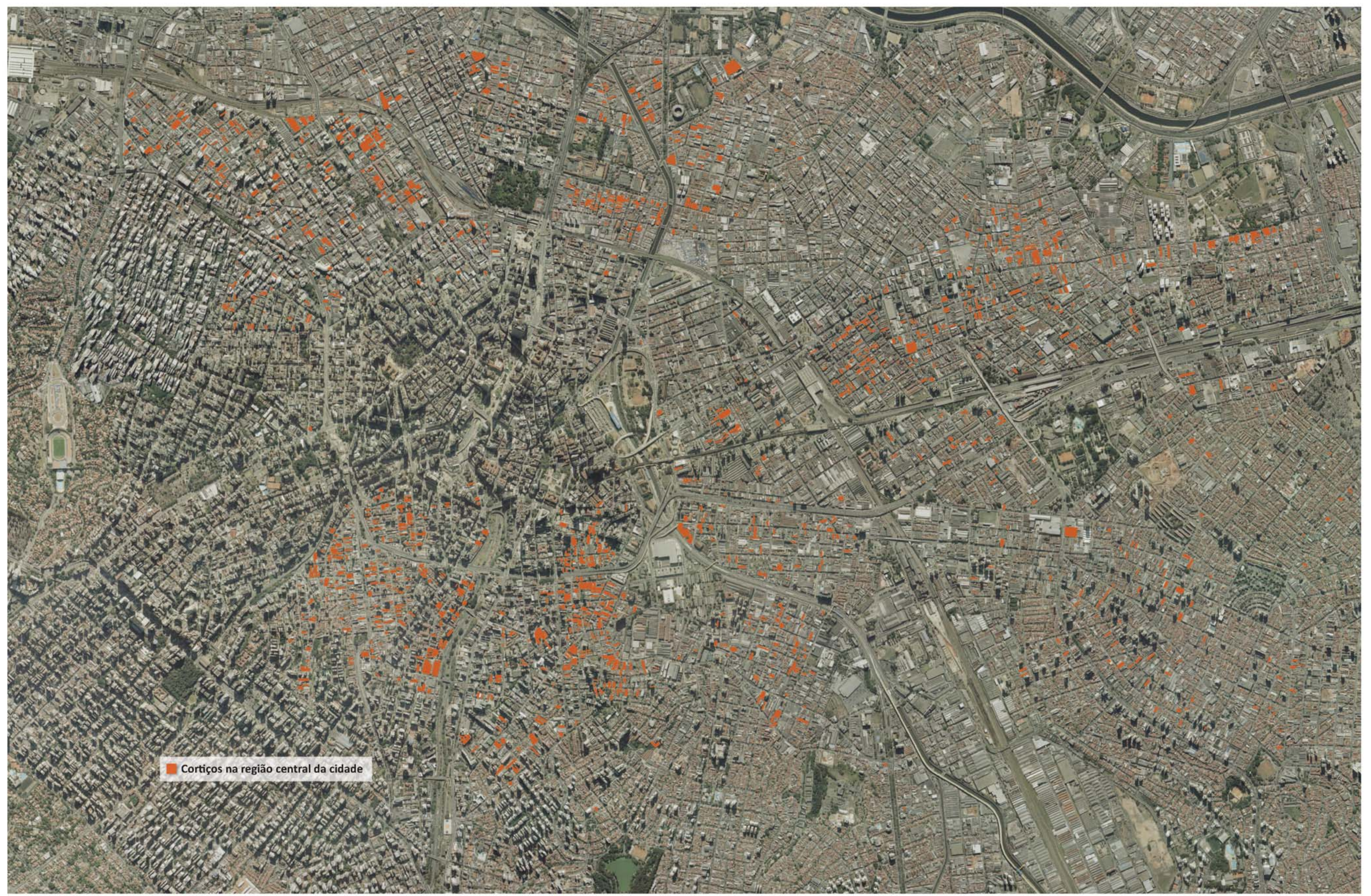

Figura 3 - Localização dos imóveis encortiçados na região central de São Paulo 


\subsection{Programa em larga escala e levantamento dos imóveis encortiçados}

Em 2005, foi contratado um projeto de assistência técnica desenvolvido com a Aliança de Cidades $^{31}$ em conjunto com a Secretaria Municipal de Habitação. Foram encomendados estudos visando abranger aspectos da demanda quanto à sua quantificação, qualificação e localização no perímetro urbano e estudos de oferta referente à produção habitacional pelos três níveis de governo, linhas de financiamento e políticas de subsídio.

O início dos trabalhos se deu com o processo de planejamento estratégico realizado através de oficinas técnicas com as equipes multidisciplinares da Superintendência da Habitação Popular (Habi), onde foram definidas as etapas que seriam implementadas nas atividades do Programa de Cortiços.

A equipe de Habi-Centro era composta de 15 profissionais de diferentes disciplinas. Três arquitetos, dois engenheiros, dois sociólogos, três assistentes sociais e cinco estagiários de Arquitetura. Para desenvolver o planejamento estratégico do Programa de Cortiços somou-se a essa equipe o corpo técnico da Cities Alliance formado por três arquitetos que coordenaram as atividades de desenvolvimento do Plano.

Uma das premissas mais importantes era que o alcance das ações deveria ser abrangente no bairro da Mooca, no centro e demais bairros centrais, como República, Santa Ifigênia, Bom Retiro, etc. O programa de atividades baseado fundamentalmente na fiscalização do uso dos imóveis, entendido como modelo de bens e serviços habitacionais, não deveria se dar pontualmente como havia sido em outras épocas. Desejava-se atingir soluções em larga escala nos imóveis encortiçados.

Decorre daí um problema. Tinha-se uma estimativa de 1.648 cortiços existentes no centro da cidade (Figura 3), o que poderia alcançar uma população de

\footnotetext{
${ }^{31}$ A Aliança de Cidades (Cities Alliance) é um consórcio internacional de cidades e organismos de desenvolvimento econômico e social comprometidos em encontrar soluções para a redução da pobreza. A Aliança de Cidades tem como objetivo promover o papel de governos locais na estruturação de políticas de desenvolvimento urbano e melhoria em assentamentos urbanos, mobilizando o apoio internacional de agências bilaterais e multilaterais.
} 
aproximadamente 38 mil habitantes, isto é, o formato do programa em larga escala deveria abranger todo esse universo.

Inicialmente, a quantificação e a qualificação dos cortiços foram definidas como as primeiras atividades a serem realizadas. Logo, seria necessário entrar nos imóveis para conhecer, levantar e anotar peculiaridades/características dos cortiços do centro da cidade, isto é, realizar o levantamento de todos os imóveis encortiçados.

Larga escala sugere uma equação de tempo e quantidade, pelo que se desenvolveram instrumentais de vistoria apropriados para atender a tal equação, que tem como variáveis a quantidade de técnicos envolvidos no levantamento, a quantidade de tempo desejado em cada imóvel e a quantidade de imóveis a serem levantados. Esta última era sabida, ou pelo menos estimada. Restava definir o tempo e o número de funcionários necessários para cada imóvel.

O instrumental nomeado como Vistoria Prévia ${ }^{32}$ foi desenvolvido visando a uma permanência nos imóveis de 40 minutos, possibilitando o levantamento de pelo menos cinco imóveis por técnico/dia.

Os dados coletados nos imóveis podem ser divididos em cinco grupos: 1. Dados gerais do imóvel; 2. Dados gerais do uso do imóvel como cortiço; 3 . Itens da Lei Moura; 4. Dados gerais das condições edilícias do imóvel; e 5. Dados socioeconômicos dos moradores.

Nesse levantamento, as condições de habitabilidade dos cortiços ficam registradas com a atribuição de notas para cada item. Posteriormente, as notas são migradas para o banco de dados do Sistema de Informações - Habisp (ver 2.6).

O primeiro e o segundo grupo são dados gerais dos cortiços e não requerem atribuição de nota. No terceiro grupo temos itens relacionados às condições de habitabilidade mencionados na Lei Moura. Nesse caso temos apenas duas possibilidades: ou o item está em conformidade com a lei ou não está.

No quarto grupo temos dados que não constam na lei, pelo que foi atribuída uma graduação para a não conformidade.

\footnotetext{
${ }^{32}$ Documento chamado Vistoria Prévia consta em processos administrativos autuados pela Secretaria de Habitação ou Subprefeitura da Mooca contendo informações acerca do levantamento executado em imóveis encortiçados.
} 
Os dados do primeiro grupo são levantados em bancos de dados existentes na prefeitura. A partir do número do contribuinte do imóvel, o departamento da HabiCentro tem condições de investigar as informações internamente na prefeitura.

Especificamente, os itens 1, 2 e 3 são anotações referentes à gestão do Programa. O primeiro item do quadro abaixo trata da "Indicação do Cortiço", ou proveniência da indicação do imóvel como cortiço. É a origem da informação que admite ser o imóvel um cortiço, e essa informação pode provir basicamente de três fontes diferentes: 1. Mapeamento do CDHU; 2. Denúncia de munícipes; e 3. Indicação de movimentos de moradia.

O segundo item (Grupo de Trabalho) refere-se à equipe de trabalho que realizou vistorias prévias ou de acompanhamento aos cortiços em reforma. Esses grupos de trabalho podem ser constituídos de duas formas diferentes. A primeira possibilidade é o grupo constituído por profissionais do departamento de HabiCentro e a segunda é o grupo de profissionais contratados através de gerenciadoras do Programa. Especificamente, as gerenciadoras que participaram das vistoras têm vínculos contratuais com a CDHU.

O terceiro item (Ação Específica) foi criado para identificar as sobreposições das atividades do Programa de Cortiços com outras ações do poder público municipal e estadual. A exemplo disso, há ações específicas da Polícia Civil de busca e apreensão de drogas em cortiços no distrito de Campos Elíseos. Dessa atividade policial houve interferências com o Programa de Cortiços. Na visão comum das equipes, incluindo a polícia, a regularidade que o Programa de Cortiços proporciona - tanto no imóvel quanto nas relações entre inquilinos e senhorios diminui focos de criminalidade nos imóveis.

Outras ações específicas podem ser citadas, como, por exemplo, a Concessão Urbanística ${ }^{33}$ na região da Santa Efigênia

A concessão urbanística constitui instrumento de intervenção urbana estrutural destinado à realização de requalificação da infraestrutura urbana e do reordenamento do espaço urbano da tal forma que o programa de cortiços, sendo fundamentalmente um programa de fiscalização seguido de trabalho social, pode se

\footnotetext{
33 Primeira Concessão Urbanística para a área da Nova Luz aprovada na cidade de São Paulo por meio da Lei No 14.918 de 7 de Maio de 2009.
} 
ver potencializado com intervenções provenientes das atividades resultantes da aplicação da concessão urbanística.

Tabela 4 - Dados gerais do imóvel encortiçado

\begin{tabular}{|r|l|}
\hline 1 & Indicação do cortiço \\
\hline 2 & Grupo de trabalho \\
\hline 3 & Ação específica \\
\hline 4 & Subprefeitura \\
\hline 5 & Nome da rua \\
\hline 7 & Número \\
\hline 8 & Distrito \\
\hline 9 & Nome do proprietário \\
\hline 10 & Nome do intermediário \\
\hline 11 & Telefones \\
\hline 12 & Área do terreno \\
\hline 13 & Testada \\
\hline 14 & Profundidade do terreno \\
\hline 15 & Fração ideal \\
\hline 16 & Área construída \\
\hline 17 & Ano da construção \\
\hline 18 & Valor venal de referência \\
\hline 19 & Valor por metro quadrado \\
\hline 20 & Tipo de tombamento \\
\hline & \\
\hline
\end{tabular}

Os dados do segundo grupo são levantados no imóvel encortiçado através do instrumental "Vistoria Prévia". Não são itens que estejam mencionados na Lei Moura, porém contribuem para a caracterização dos cortiços:

Tabela 5 - Dados gerais do uso do imóvel encortiçado

\begin{tabular}{|l|l|}
\hline 21 & Tipologia da edificação \\
\hline 22 & Uso da quadra \\
\hline 23 & Quantidade de quartos \\
\hline 24 & Quantidade de banhos \\
\hline 25 & Quantidade de vasos sanitários \\
\hline 26 & Quantidade de chuveiros \\
\hline 27 & Quantidade de cozinhas \\
\hline 28 & Quantidade de área de serviço \\
\hline 29 & Quantidade de lavatórios \\
\hline
\end{tabular}


Os dados do terceiro grupo são referentes ao artigo $3^{\circ}$ da Lei Moura. Os itens mais importantes que se referem às questões de salubridade, como umidade, iluminação e ventilação, se encontram neste grupo.

Tabela 6 - Dados levantados referentes à Lei Moura
\begin{tabular}{|l|l|}
\hline 30 & Quantidade de tanques de lavar \\
\hline 31 & Ventilação \\
\hline 32 & lluminação \\
\hline 33 & Área mínima \\
\hline 34 & Adensamento máximo \\
\hline 35 & Revestimento impermeável de parede no banheiro \\
\hline 36 & Pé direito mínimo de 2,30 metros \\
\hline 37 & Largura da circulação da escada \\
\hline
\end{tabular}

No quarto grupo temos dados relativos às condições físicas do imóvel, às questões estruturais e às concessionárias. A não conformidade neste grupo é tratada em quatro níveis, considerando "D" como péssimo, indicando risco à segurança dos moradores e não possibilitando condições de uso; "C" como ruim, não apresentando risco à segurança, porém comprometendo a sua utilização; "B" como regular, não apresentando risco à segurança nem comprometendo sua utilização; e, por último, "A" como bom, com ressalvas, não apresentando risco à segurança nem comprometendo sua utilização, porém requisitando manutenção periódica.

Vale a observar que o item 46 trata de material granulado inflamável, proveniente da atividade de catação de lixo nas ruas. Em geral, o catador acumula o material coletado nas dependências do cortiço. A anotação que é feita pela equipe de vistoria é se o material é de natureza inflamável e se há possibilidade de ocasionar incêndio no cortiço devido ao seu acondicionamento. 
Tabela 7 - Dados gerais das condições de habitabilidade do imóvel encortiçado

\begin{tabular}{|l|l|}
\hline 38 & Trincas ou fissuras \\
\hline 39 & Sinais de infiltração \\
\hline 40 & Armaduras expostas \\
\hline 41 & Forro \\
\hline 42 & Telhado \\
\hline 43 & Vedação - divisória \\
\hline 44 & Localização dos botijões de gás \\
\hline 45 & Extintores \\
\hline 46 & Material granulado inflamável \\
\hline 47 & Rede da Eletropaulo \\
\hline 48 & Rede interna - elétrica \\
\hline 49 & Quadro de luz \\
\hline 50 & Pontos de tomada \\
\hline 51 & Instalação de alimentação de água - Sabesp \\
\hline 52 & Instalações de esgoto \\
\hline 53 & Rede interna - hidráulica \\
\hline 54 & Total de cômodos \\
\hline 55 & Cômodos vagos \\
\hline 56 & Entrada da Eletropaulo \\
\hline 57 & Cavalete da Sabesp \\
\hline
\end{tabular}

Finalmente, no quinto grupo temos dados preliminares da situação socioeconômica das famílias moradoras nos cortiços obtidos através de um arrolamento. Posteriormente, em uma etapa mais avançada do Programa de Cortiços, as famílias são cadastradas através de um instrumental detalhado denominado pesquisa socioeconômica que segue padrões capazes de fornecer as informações exigidas por critérios de atendimento habitacional instituídos pelo Conselho Municipal de Habitação (CMH).

Tabela 8 - Dados socioeconômicos do arrolamento das famílias

\begin{tabular}{|r|l|}
\hline 58 & Aluguel médio \\
\hline 59 & Renda média das famílias \\
\hline 60 & Total de familias no imóvel \\
\hline 61 & Total de pessoas no imóvel \\
\hline
\end{tabular}




\subsection{Os primeiros imóveis intimados e vistoriados}

Data de 3 de novembro de 2005 a primeira intimação lavrada em cortiços após a publicação em 1991 da Lei Moura na cidade de São Paulo.

À época, a Coordenação de Planejamento e Desenvolvimento Urbano (CPDU) da Subprefeitura da Mooca mantinha uma divisão de fiscais por regiões no território da Subprefeitura da Mooca. Para cada fiscal, era designada uma região, sendo, ao todo, 14 regiões distribuídas pelos nove distritos que compõem a subprefeitura.

Três fiscais foram selecionados, e a eles foram passados os primeiros endereços de cortiços que integravam o mapeamento de cortiços da CDHU para serem intimados.

Foram intimados os primeiros 22 cortiços da cidade de São Paulo a fazerem reformas de adequação à Lei no 10.928, de 1991.

Tabela 9 - Primeiros imóveis intimados pelo Programa

\begin{tabular}{|l|l|l|}
\hline \multicolumn{2}{|c|}{ Nome da rua } & Número \\
\hline 1 & Rua Araguaia & 168 \\
\hline 2 & Rua Itariri & 197 \\
\hline 3 & Rua Morais Barros & 160 \\
\hline 4 & Rua Dom Bosco & 684 \\
\hline 5 & Rua Marquês de Abrantes & 20 \\
\hline 6 & Rua Carnot & 456 \\
\hline 7 & Rua Vautier & $165 / 167 / 169$ \\
\hline 8 & Rua Curupace & 264 \\
\hline 9 & Rua Hipódromo & 257 \\
\hline 10 & Rua Canindé & 414 \\
\hline 11 & Rua Itariri & 166 \\
\hline 12 & Rua Bresser & 1362 \\
\hline 13 & Rua Bresser & 1360 \\
\hline 14 & Rua Itariri & 234 \\
\hline 15 & Rua Canindé & 870 \\
\hline 16 & Rua Canindé & 870 \\
\hline 17 & Rua Hanemann & 58 \\
\hline 18 & Rua Azevedo Júnior & 96 \\
\hline 19 & Rua Canindé & 503 \\
\hline 20 & Rua Vautier & $147 / 149$ \\
\hline 21 & Rua Visconde Parnaíba & 2835 \\
\hline 22 & Rua Júlio Castilho & 578 \\
\hline
\end{tabular}


A reação à intimação da subprefeitura foi diferente em cada imóvel, variando de acordo com quem atendia o agente vistor. Entre os que atendiam estavam: 1. 0 intermediário; 2. Morador; 3. Imobiliária; 4. Proprietário do imóvel; e 5. Zelador do cortiço.

As principais reações foram incredibilidade, desconhecimento em relação à lei, medo de despejo e hostilidades em geral. Imediatamente após ação do agente vistor, as equipes de arquitetos e engenheiros realizaram as visitas técnicas dispondo do instrumental de vistoria prévia para a coleta de dados das condições de habitabilidade dos imóveis.

A equipe de gestão do Programa reconheceu erros durante as visitas dos primeiros imóveis. O instrumental foi revisto após a identificação de erros no formulário e de itens que precisavam ser reformulados.

Em apenas um caso, no cortiço da Rua Hanemann, 58, a equipe de gestão do Programa perdeu total contato com as famílias. Provavelmente, o proprietário ou responsável pelo imóvel, receoso da ação inédita da prefeitura, optou por despejar todas as famílias e lacrar o imóvel.

De todos os imprevistos, este foi o mais grave, pois atenta para um dos pressupostos do Quadro Lógico do Programa, que adverte contra a alta rotatividade das famílias nos cortiços em detrimento da segurança na posse.

Nessa etapa do desenvolvimento do Programa foi possível observar a inviabilidade de elaborar projetos de reforma para cada cortiço. A similaridade das irregularidades é um aspecto positivo sob a ótica da padronização das planilhas orçamentárias e da otimização do desenvolvimento de projetos de reforma. Tecnicamente sabemos que não há grandes dificuldades para o desenvolvimento desses projetos, posto que as irregularidades requerem obras de execução simples. Por outro lado, tamanha semelhança induziu à busca de outro tipo de solução.

A similaridade e simplicidade dessas irregularidades, comum a grande parte desses imóveis encortiçados, norteou a busca por uma solução que tivesse afinidade com um alcance mais abrangente.

O desejo de as ações de regularização dos imóveis serem de longo alcance poderia estar relacionado ao desenvolvimento de um mecanismo de seleção sistemática de serviços de obra. 


\subsection{Revisão de planejamento e recomendação de obra}

O início do Programa de Cortiços foi marcado pelos imprevistos encontrados nos primeiros imóveis intimados na Subprefeitura da Mooca, assim como as primeiras percepções da equipe técnica a respeito das diversas condições de habitabilidade dos cortiços que nortearam a revisão de planejamento do Programa.

Logo após as primeiras intervenções, em novembro de 2005, nos 22 cortiços da Subprefeitura da Mooca, observou-se a inviabilidade de elaborar projetos de reforma para cada cortiço. A inviabilidade decorre da impossibilidade de compatibilizar uma ação em larga escala com o tempo necessário para o desenvolvimento de projetos.

À época, a equipe técnica de cortiços fez tentativas, todas infrutíferas, de realizar o projeto de reforma e seu respectivo orçamento como forma de prestação de serviço público para os proprietários (ou responsáveis) de cortiços. Ficou evidente que não haveria tempo hábil para todas essas tarefas em um projeto que tinha como premissa o longo alcance de suas ações. Dos 22 cortiços, apenas seis tiveram seus projetos e orçamentos desenvolvidos, porém em um prazo de quase dois meses. Logo ficou evidente que seria possível realizar projetos para os cerca de 1.600 cortiços do centro da cidade.

O problema a ser resolvido era: como realizar reformas - pequenas reformas segundo Código de Obras e Edificações (COE) - sem o desenvolvimento de projetos/orçamentos e sua consequente aprovação?

Em princípio, para a realização de uma obra é necessário um projeto devidamente aprovado não só pelos órgãos municipais competentes, mas, dependendo do caso, também estaduais. Quando se tratar especificamente das pequenas reformas ${ }^{34}$, definidas no código de obras como aquelas que não trazem alterações estruturais ao imóvel, ainda que haja alteração de uso, não é necessária a apresentação de projeto aprovado.

${ }^{34}$ Código de Obras do Município, Capítulo 1, 1-1 Conceitos. 
Por consequência, não havendo a necessidade de projeto, a equipe de cortiços definiu, como parte da metodologia do Programa, a substituição do projeto por um instrumental semelhante ao auto de infração emitido pelo Departamento de Controle de Uso de Imóveis (Contru) ${ }^{35}$. Este documento, entregue ao proprietário infrator, traz a relação das irregularidades observadas pelo agente vistor no imóvel objeto de inspeção. Ao instrumental criado pela equipe de cortiços deu-se o nome de "Recomendação de Obras".

Em sua essência, o instrumental nada mais é do que um check list dos serviços a serem executados para a adequação do imóvel. No entanto, o instrumental tem um aspecto didático, para que o usuário de imóveis encortiçados compreenda todas as orientações.

Os dados que compõem a recomendação de obras são extraídos do levantamento do imóvel feito através do instrumental "Vistoria Prévia".

Após a entrega do documento, fica o responsável pelo imóvel incumbido de executar os serviços de obra elencados no documento dentro de um prazo estabelecido pela subprefeitura responsável ou pela Superintendência de Habitação Popular (Habi).

Em seguida, dá-se início a uma nova etapa do Programa. As obras iniciadas recebem o acompanhamento de uma equipe de arquitetos e de engenheiros da Superintendência de Habi com o objetivo de sanar dúvidas referentes aos serviços de obras e prestar quaisquer orientações que contribuam para o desenvolvimento da obra. Em média são realizadas três visitas técnicas por imóvel.

35 O Departamento de Controle de Uso de Imóveis (Contru) opera na Secretaria Municipal de Habitação e faz parte da Comissão Integrada de Fiscalização (CIF) criada pelo Decreto $n^{\circ} 50.939$, de 21 de janeiro de 2009. 


\subsection{Aspectos da fiscalização e perenidade da ação fiscalizatória}

Uma vez realizado o piloto nos 22 cortiços da Mooca, onde foram redefinidos os passos das equipes técnicas após a etapa de replanejamento do Programa, com a instituição do instrumental que substitui o projeto e a validação do instrumental de vistoria, o Programa estava pronto para ser implementado no restante do território da Subprefeitura da Mooca. Restava apenas planejar a atuação dos agentes fiscais de forma compatível com a premissa do Programa em larga escala.

Embora o Programa de Cortiços trate de um tema habitacional que aborda uma situação de extrema precariedade e vulnerabilidade social, o departamento da Prefeitura do Município de São Paulo responsável pela fiscalização das mais variadas construções, usos e atividades na cidade é a subprefeitura. São ao todo 31 subprefeituras que dividem os $1.500 \mathrm{~km}^{2}$ do território paulistano. Vinculadas à Secretaria Municipal de Coordenação de Subprefeituras ${ }^{36}$, elas detêm, entre uma série de outras competências, o poder fiscal e, inclusive, gerencial do policiamento da cidade através da Guarda Civil Metropolitana.

A fiscalização em imóveis encortiçados não é diferente. Embora esses imóveis sejam representativos de uma situação social de extrema vulnerabilidade e sua população moradora faça parte das camadas sociais mais pobres da cidade, que muitas vezes demanda serviços relacionados principalmente à saúde, à educação e à assistência social, os imóveis encortiçados são também passíveis de fiscalização quanto à edificação e ao seu uso.

A aplicação de fato da Lei Moura ocorreu em 2005, o que nos dá apenas seis anos de conhecimento dos resultados de sua aplicação, ocorrida em uma área específica no centro da cidade de São Paulo, que abrangeu 61,4 km².

Em novembro de 2005, fiscais da Coordenadoria de Planejamento e Desenvolvimento Urbano (CPDU), da Subprefeitura Mooca, iniciaram a fiscalização

${ }^{36}$ Secretaria criada através da Lei $n^{\circ} 13.399$, de $1^{\circ}$ de agosto de 2002. Dispõe sobre a criação, estrutura e atribuições das subprefeituras no município de São Paulo, estabelece procedimentos para sua implantação e prevê a transferência gradual de órgãos e funções da Administração Direta Municipal. 
em 527 endereços suspeitos de serem cortiços. Os responsáveis pelos imóveis, locatários ou sublocadores, deveriam, a partir da notificação, prestar esclarecimentos e apresentar documentos comprobatórios de que o cortiço estaria de acordo com as exigências da lei vigente. Posteriormente, em 2007, o mesmo trabalho teve início na CPDU da Subprefeitura da Sé tendo como alvo uma lista de 1.121 endereços suspeitos de serem cortiços.

Tais endereços pertenciam a um mapeamento de cortiços realizado no ano 2001 pela CDHU, no âmbito do contrato com o Banco Interamericano de Desenvolvimento (BID) para o financiamento de ações do Programa de Ação em Cortiços (PAC), do CDHU.

Iniciaram-se as fiscalizações com um número de 1.648 endereços de possíveis cortiços nas duas subprefeituras centrais. Durante essa etapa, houve participação significativa da vizinhança dos bairros abrangidos pela fiscalização através de denúncias e de solicitação de serviços feitas à prefeitura e dos principais movimentos de moradia em atividade na região através de encaminhamento de diversas listas de imóveis encortiçados, resultando em um acréscimo da quantidade de imóveis a fiscalizar, que totalizou 2.194 endereços de possíveis imóveis encortiçados.

Em sua essência, o ato de fiscalizar é bastante simples. Requer apenas a entrega do auto de infração a qualquer pessoa que atenda o fiscal da prefeitura, ficando o receptor responsável por entregar a intimação ao responsável pelo imóvel ou ao proprietário ${ }^{37}$.

Não havendo efeito, a subprefeitura poderá repetir a intimação ou proceder às sanções previstas na lei, como, por exemplo, a aplicação de multa ${ }^{38}$. Reserva-se

37 Texto do artigo 23 da Lei do Inquilinato, inciso VII: "Entregar imediatamente ao locador os documentos de cobrança de tributos e encargos condominiais, bem como qualquer intimação, multa ou exigência de autoridade pública, ainda que dirigida a ele, locatário".

${ }^{38}$ Texto do artigo $7^{\circ}$ da Lei $n^{\circ} 10.928 / 91$. Lei Moura: "As infrações à presente lei serão objeto de 2 (duas) notificações consecutivas para sua correção plena, as quais estabelecerão prazos para as providências determinadas. Parágrafo $1^{\circ}$ - Desatendidas as notificações da autoridade, será aplicada aos infratores a multa de 20 (vinte) a 200 (duzentas) UFMs, sem prejuízo de sujeitar-se o imóvel à declaração de utilidade pública ou de interesse social para fins de desapropriação, neste caso mantida sua destinação residencial pelo Poder Público. Parágrafo $2^{\circ}$ - Quando as condições físicas e de habitabilidade do cortiço evidenciarem grave e iminente risco à vida ou à saúde dos moradores, a autoridade municipal competente, mediante laudo fundamentado, o interditará, sem prejuízo das sanções administrativas e penais a que estiverem sujeitos o proprietário, o locatário-sublocador, 
ainda o direito do servidor público competente de autuar um processo administrativo ex officio $^{39}$ para garantir o prosseguimento do trabalho fiscalizatório ${ }^{40}$. De fato, em 2008, na iminência de uma possível mudança de prefeito da cidade de São Paulo, por efeito das eleições municipais de outubro de 2008, a equipe de gestão do Programa de Cortiços optou por autuar processos administrativos para cada ação fiscalizatória nos cortiços da Mooca, equivalendo a um processo administrativo por imóvel.

Nos processos administrativos é possível encontrar documentada toda a ação do poder público realizada nos imóveis. Pela regra, esses processos somente podem ser encerrados e enviados para o arquivo geral da prefeitura pelo departamento que autuou o processo. Isso significa que, sendo a própria equipe de gestão do Programa que autuou os processos, estes somente serão encaminhados para o arquivo geral se os trabalhos em determinado cortiço forem finalizados de maneira satisfatória pela equipe, o que ocorre apenas após o aviso do término da obra de adequação do imóvel e sua correspondente vistoria final realizada por técnico integrante da equipe.

Pode-se concluir que a abertura de processos administrativos ex officio, realizados pela própria equipe de gestão do Programa de Cortiços, garante que a intervenção em um imóvel encortiçado se desenvolva desde seu início até o fim independentemente de mudanças de gestão de governo - das atividades de adequação do imóvel, uma vez que responsabilidades administrativas recaem sobre o servidor público que se omitir perante o expediente constante no processo administrativo.

terceiros que tomarem o lugar destes e/ou o responsável pela exploração, ou, se julgar conveniente, realizará de imediato, as obras necessárias à eliminação do risco, delas se ressarcindo ulteriomente". ${ }^{39}$ Diz-se de processo administrativo autuado pelo poder público e não por munícipe.

${ }^{40}$ Atualmente, existem 152 processos administrativos em trânsito referentes a atividades relacionadas ao Programa de Cortiços (agosto de 2010). 


\subsection{Sistema de Priorização da Superintendência de Habitação Popular da Secretaria Municipal de Habitação (Habisp)}

A construção do Sistema de Priorização teve início em julho de 2006 através de um modelo coletivo de desenvolvimento de propostas que se deu ora em grupos ampliados envolvendo o corpo técnico da Habi, ora em grupos reduzidos envolvendo equipes de consultores da Aliança de Cidades.

Destacam-se três atividades importantes no momento de sua construção: 1. A definição do modelo do Sistema; 2. A atualização das informações sobre favelas e cortiços; e 3. A alimentação do Sistema de Informações Gerenciais.

$\mathrm{Na}$ primeira atividade, a definição do modelo do sistema refere-se à caracterização, classificação, elegibilidade e priorização de atuação em imóveis encortiçados, assim como dos critérios de elegibilidade, dos índices a serem utilizados em suas análises e dos modelos de cálculo para a elaboração do índice de priorização.

A segunda atividade que trata da atualização das informações, no caso dos cortiços, refere-se à atualização dos endereços de imóveis encortiçados que constavam no mapeamento do CDHU.

A terceira atividade trata do desenvolvimento de documentos necessários aos procedimentos burocráticos exigidos pelo funcionalismo público e de relatórios gerenciais a serem gerados pelo próprio sistema.

Os 61 itens levantados nas vistorias prévias realizadas nos imóveis encortiçados constam no Sistema de Priorização em uma base de cálculos em que cada um dos 61 itens levantados recebe uma pontuação atrelada a um peso de acordo com sua importância.

Antes mesmo de a base de cálculo estar operando, a equipe técnica do Programa estabeleceu quatro classificações dos imóveis encortiçados que posteriormente foram validadas pelo "rankeamento" do Sistema de Priorização.

As classificações são referentes à quantidade de serviços de obra necessários para a adequação à Lei Moura: pequeno porte de obra, médio porte de 
obra, grande porte de obra e interdição. Esta última foi definida não pela impossibilidade de realizar uma obra, e sim pelo nível extremo de degradação, o que resulta no entendimento de que não seria cabível a continuidade do uso habitacional do imóvel.

Os itens levantados nas vistorias foram distribuídos em quatro grupos de pontuação: salubridade, estrutural, incêndio e instalações. Cada grupo recebeu um peso conforme o quadro a seguir:

Tabela 10 - Pesos dos grupos de itens do Sistema de Informações (Habisp)

\begin{tabular}{|l|c|}
\hline Classe de Risco & Peso \\
\hline Salubridade (Lei Moura) & $\mathbf{2}$ \\
\hline Estrutural & $\mathbf{3}$ \\
\hline Incêndio & $\mathbf{3}$ \\
\hline Sistemas: Eletropaulo e Sabesp & $\mathbf{1}$ \\
\hline Vulnerabilidade social: Não há dados & \\
\hline
\end{tabular}

Como podemos observar, a equipe de gestão do Programa de Cortiços definiu como prioridade as questões estruturais e de segurança contra incêndio, adotando para os dois grupos de pontuação o peso máximo no valor "3".

Os itens do grupo de salubridade englobam os dados levantados referentes à Lei Moura. Cada atributo tem uma pontuação relacionada a uma conformidade ou não conformidade em relação à Lei Moura. A não conformidade leva um valor igual a zero e a conformidade varia de 3 a 1 .

Tabela 11 - Pesos dos atributos referentes à Lei Moura

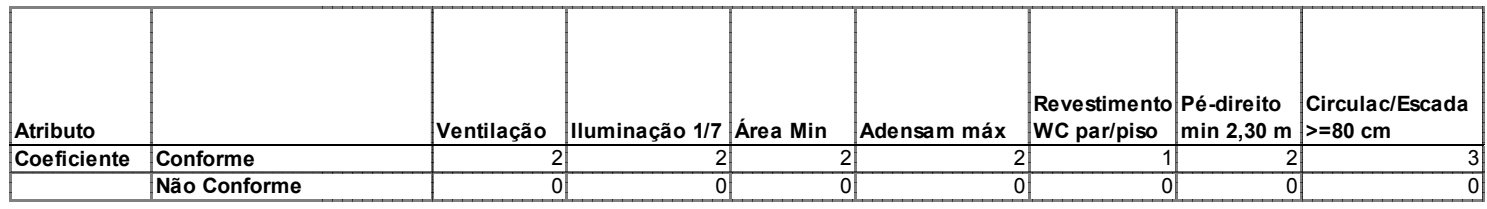

Os itens do grupo estrutural têm quatro níveis de não conformidade, cada qual com uma pontuação diferente. Para a conformidade verificada, o valor atribuído é 4, enquanto que a não conformidade alcança a nota 3 nos melhores casos, seguida das notas 2, 1 e zero nos casos de não conformidade em seu estado máximo: 
Tabela 12 - Peso dos atributos gerais levantados nos imóveis encortiçados

\begin{tabular}{|c|c|c|c|c|c|c|c|c|c|}
\hline Atributo & & $\begin{array}{l}\text { Sinais de } \\
\text { infiltrações }\end{array}$ & $\begin{array}{l}\text { Rede } \\
\text { interna } \\
\text { de água }\end{array}$ & $\begin{array}{l}\text { Instalações } \\
\text { de esgoto }\end{array}$ & $\begin{array}{l}\text { Trincas } \\
\text { ou } \\
\text { Fissuras }\end{array}$ & $\begin{array}{l}\text { Ferragens } \\
\text { expostas }\end{array}$ & Forro & Telhado & $\begin{array}{l}\text { Vedação/ } \\
\text { divisoria }\end{array}$ \\
\hline Coeficiente & Conforme & 4 & 4 & 4 & 4 & 4 & 4 & 4 & 4 \\
\hline & Não Conforme & 0 & 0 & 0 & 0 & 0 & 0 & 0 & 0 \\
\hline & Bom - Não conforme & 3 & 3 & 3 & 3 & 3 & 3 & 3 & 3 \\
\hline & Regular - Não conforme & 2 & 2 & 2 & 2 & 2 & 2 & 2 & 2 \\
\hline & Ruim - Não conforme & 1 & 1 & 1 & 1 & 1 & 1 & 1 & 1 \\
\hline & Péssimo - Não conforme & 0 & 0 & 0 & 0 & 0 & 0 & 0 & 0 \\
\hline
\end{tabular}

Tabela 13 - Peso dos atributos gerais levantados nos imóveis encortiçados

\begin{tabular}{|l|l|l|r|r|r|r|r|r|r|}
\hline & & $\begin{array}{l}\text { Localiza } \\
\text { ção de } \\
\text { botijões }\end{array}$ & Extintores & $\begin{array}{l}\text { Material } \\
\text { Granulado } \\
\text { Inflamável }\end{array}$ & $\begin{array}{l}\text { Rede } \\
\text { Interna } \\
\text { elétrica }\end{array}$ & $\begin{array}{l}\text { Quadro } \\
\text { de Luz }\end{array}$ & $\begin{array}{l}\text { Pontos } \\
\text { de } \\
\text { Tomadas }\end{array}$ & $\begin{array}{l}\text { Rede da } \\
\text { Eletropaulo }\end{array}$ & $\begin{array}{l}\text { Instalação } \\
\text { água - SABESP }\end{array}$ \\
\hline Coeficiente & Conforme & 4 & 4 & 4 & 4 & 4 & 4 & 1 \\
\hline & Não Conforme & 0 & 0 & 0 & 0 & 0 & 0 & 0 \\
\hline & Bom - Não conforme & 3 & 3 & 3 & 3 & 3 & 3 & \\
\hline & Regular - Não conforme & 2 & 2 & 2 & 2 & 2 & 2 & \\
\hline & Ruim - Não conforme & 1 & 1 & 1 & 1 & 1 & 1 & \\
\hline & Péssimo - Não conforme & 0 & 0 & 0 & 0 & 0 & & \\
\hline
\end{tabular}

No Sistema, todos os imóveis recebem uma nota a partir do cruzamento das informações e da atribuição de pesos feita a cada indicador. A ponderação desses indicadores levará a uma nota geral para cada imóvel que o posicionará em uma lista de prioridades de intervenção para o Programa.

Observamos que a priorização dos imóveis encortiçados está balizada pelas condições de salubridade e demais condicionantes das questões de habitabilidade dos imóveis. No entanto, ordens de outras grandezas se fundem com as atividades do Programa de Cortiços.

Por um lado, o Sistema de Priorização é um guia técnico para o planejamento das ações que se inicia com o atendimento aos cortiços que apresentam as piores condições de habitabilidade. Por outro lado, decisões judiciais e fenômenos da natureza como chuvas fortes, alagamentos, tempestades, etc. podem alterar a ordem da priorização prevista.

Outro fator importante é a revisão dos pesos dos atributos, decisão que pode constar na programação da equipe de gestão do Programa e alterar o resultado da priorização.

De fato, à medida que os imóveis iniciam suas obras a equipe de gestão realiza visitas de acompanhamento de obras. Nessas visitas são anotados os serviços de obras já realizados, gerando uma informação ao Sistema que computa o 
item recentemente adequado com sua nota correspondente. Logo, a nota do imóvel pode ser ajustada durante a realização de obra.

Prevê-se que, a partir da melhoria das condições de habitabilidade dos imóveis, os pesos dos itens levantados podem ser revistos de acordo com a mudança de panorama dos cortiços em geral.

\subsection{Fluxograma do Programa de Cortiços}

Relatamos aqui o fluxograma do Programa de Cortiços da Superintendência de Habitação Popular, desenvolvido no âmbito do Quadro Lógico do projeto de implementação do Programa.

O fluxograma aponta, passo a passo, as atividades desenvolvidas no Programa de Cortiços, desde o início do processo por meio de uma denúncia ou pela indicação do mapeamento até o instante final do atendimento habitacional às famílias e a interdição ou mudança de uso do imóvel encortiçado.

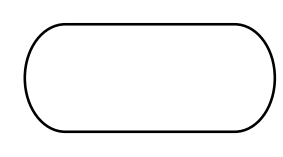

\section{Fiscal identifica cortiço novo / Denúncia de cortiço novo}

A denúncia de um cortiço feita por munícipes através dos canais formais da Prefeitura do Município de São Paulo $^{41}$ ou a identificação de um imóvel usado como moradia coletiva por fiscal da prefeitura ou técnicos da Secretaria Municipal de Habitação iniciam o processo de trabalho de readequação de um imóvel encortiçado. Essa atividade gera um dado denominado "Indicações

\footnotetext{
${ }^{41}$ As denúncias podem ser feitas através do número de telefone 156, através do portal da prefeitura (www.capital.sp.gov.br) ou através das praças de atendimentos das 31 subprefeituras da cidade de São Paulo.
} 
Recebidas" no Relatório de Progresso do Programa de Cortiços.

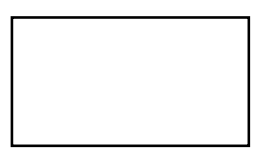

\section{Identificação da subprefeitura responsável}

Uma vez identificado o imóvel, ainda que não se tenha constatado de fato se é um cortiço, o segundo passo é identificar a localização e por consequência a subprefeitura a que compete a fiscalização.

\section{Encaminhamento para a subprefeitura}

O documento gerado pela denúncia ou pela identificação do técnico é encaminhado para a subprefeitura responsável.

\section{Intimação do imóvel}

A subprefeitura responsável envia fiscal ao endereço identificado ou denunciado como cortiço e lavra a intimação. Uma via da intimação fica com o responsável pelo imóvel e a outra via é anexada à documentação do imóvel na prefeitura para acompanhamento.

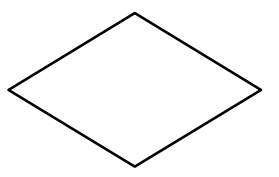

5 Proprietário responde à intimação

Ainda que o poder público entregue a intimação ao proprietário do imóvel, é responsabilidade do munícipe se apresentar ao órgão público, podendo no caso do Programa de Cortiços ser a subprefeitura que lavrou a intimação ou a Secretaria Municipal de Habitação.

SIM

Caso o proprietário ou responsável pelo imóvel se manifeste ao receber a intimação, a Secretaria Municipal de Habitação encaminha equipes técnicas para realização de uma vistoria física e social no imóvel.

Não havendo manifestação, o imóvel é intimado novamente. Se ainda não houver manifestação, o 
Programa de Cortiços realiza uma sequência de visitas de assistentes sociais, podendo chegar até duas visitas no máximo. Havendo manifestação do proprietário, a Secretaria Municipal de Habitação encaminha equipes técnicas para realização de uma vistoria física e social no imóvel. Não havendo adesão do proprietário quanto à adequação do imóvel, as famílias são encaminhadas para atendimentos habitacionais na Superintendência de Habitação Popular ou na CDHU. Logo após o atendimento às famílias, o imóvel é interditado pela subprefeitura responsável.

\section{Vistoria foi realizada?}

A vistoria é denominada "Vistoria Prévia" e tem o objetivo de obter dados socioeconômicos das famílias e de levantar dados referentes às condições de habitabilidade do imóvel. Nessa etapa fica definido se o imóvel é de fato um cortiço.

SIM

$\mathrm{NÃO}$

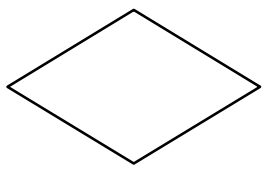

SIM

A vistoria gera uma ficha técnica do imóvel que é encaminhada para análise.

Caso não seja feita a vistoria, o proprietário do imóvel é convocado para uma reunião na subprefeitura ou na Habi para averiguação do motivo da não realização da vistoria e para agendamento de vistoria.

\section{7 É cortiço?}

Após a ficha gerada pela vistoria ser analisada, é verificado se o imóvel tem características de cortiço de acordo com definições da Lei Moura.

Se o imóvel for definido como cortiço, a ficha técnica é processada de forma a gerar um documento chamado "Recomendação de Obra". 
NÃO
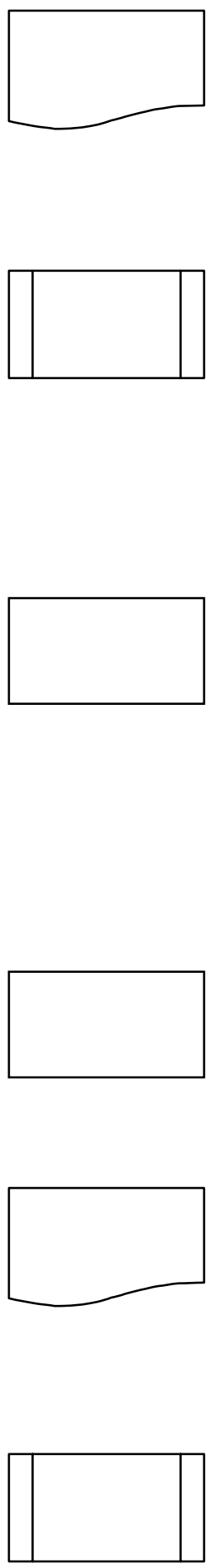

Se o imóvel não for caracterizado como cortiço, a ficha técnica gera um documento chamado "Ficha de Atualização de Cadastro".

\section{Preparação de ficha de atualização de cadastro}

A ficha de atualização de cadastro é o documento do imóvel no qual a Habi informa à subprefeitura se o imóvel vistoriado é ou não cortiço.

\section{Alimentação do Sistema de Informações Habisp}

O Sistema de Informações Habisp é alimentado de acordo com as informações da ficha de atualização de cadastro, gerando para o "Relatório de Progresso" do Programa de Cortiços a informação de "Não Cortiço".

10 Encaminhamento da ficha de atualização de cadastro para a subprefeitura

A subprefeitura é o órgão responsável pela fiscalização. Logo, caso um imóvel denunciado como cortiço seja classificado como "Não Cortiço", a subprefeitura deve ser informada oficialmente.

\section{Baixa na intimação}

Uma vez informada, a subprefeitura encerra o processo de fiscalização para aquele imóvel.

\section{Preparo da Recomendação de Obra}

Caso a análise da ficha de "Vistoria Prévia" indique a existência de um cortiço, elabora-se a "Recomendação de Obra" para adequação do cortiço à Lei Moura.

\section{Alimentação do Sistema de Informações Habisp}

O Sistema de Informações Habisp é alimentado pelas informações da "Vistoria Prévia", gerando para o "Relatório de Progresso" do Programa de Cortiços a informação "Cortiço". 

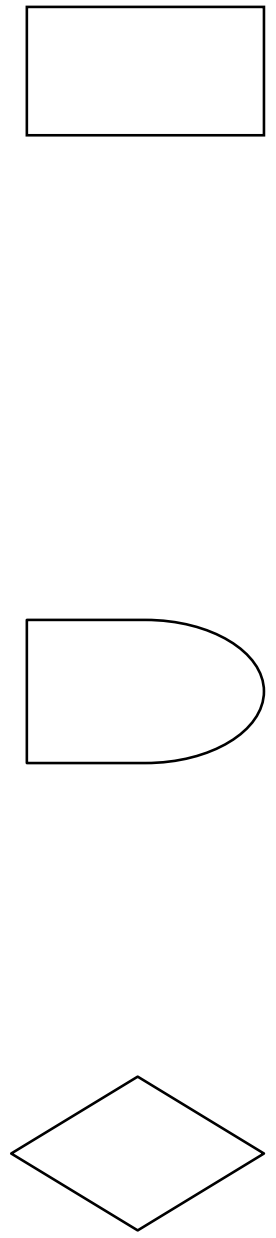

SIM

NÃO

14 Entrega pela Subprefeitura/Sehab da "Recomendação de Obra"

A "Recomendação de Obras" é entregue, pela equipe técnica de Habi ou subprefeitura, ao proprietário do imóvel ou ao responsável. Nesse momento inicia-se uma etapa de orientação prestada pela equipe técnica de ambos os órgãos públicos tanto aos responsáveis pelo imóvel quanto aos moradores.

15 Lead Time. 0 proprietário recebe a "Recomendação de Obra" e decide o destino do uso do imóvel

O Programa de Cortiços cede um prazo ao proprietário ou responsável pelo imóvel para o início da adequação à Lei Moura ou para que seja dado um outro uso ao imóvel.

\section{Proprietário vai reformar?}

O proprietário do imóvel pode tomar a decisão de reformar e adequar o imóvel à Lei Moura ou mudar o uso do imóvel. Para ambas as decisões, há o acompanhamento da Habi ou subprefeitura.

Caso o proprietário decida adequar o imóvel à Lei Moura, a Habi e a subprefeitura darão sequência a um processo de acompanhamento de obras e de trabalho social com as famílias moradoras do cortiço.

Caso a decisão do proprietário seja a de desativar o cortiço e mudar o uso do imóvel, deverá ser apresentada à prefeitura a proposta de alteração de uso do imóvel pelas vias formais da prefeitura e pelos processos normais de aprovação de projetos e de licenciamentos. Simultaneamente à mudança de uso, as famílias são encaminhadas para atendimentos habitacionais da CDHU. 17 Proprietário apresenta um cronograma de reforma 
Ao decidir adequar o imóvel à Lei Moura, o proprietário deve apresentar um cronograma de obra à prefeitura.

18 Vistorias periódicas de acompanhamento de obra

Iniciada a obra, a subprefeitura e a Habi dão prosseguimento a um acompanhamento de obra, prestando orientações.

\section{Proprietário acaba a reforma}

Finalizada a obra, é realizada uma vistoria final da obra, onde é observado se a "Recomendação de Obra" foi devidamente executada.

20 Emissão do certificado de tarifa social válido por dois anos e uma declaração de habitação coletiva

As concessionárias Eletropaulo e Sabesp concedem tarifas sociais para aqueles que apresentarem algum tipo de documento que ateste condições de vulnerabilidade social. Para tanto, a Habi emite um certificado de moradia coletiva para os imóveis que já iniciaram obras com o objetivo de obter tarifas sociais. Serve, inclusive, como medida de incentivo para que outros imóveis iniciem obras de adequação à Lei Moura.

21 Início do trabalho de pós-ocupação para as famílias que permanecerão no cortiço reformado

Durante os procedimentos que levam ao início das obras de adequação, a equipe de assistentes sociais desenvolvem atividades de apoio ao início de obras. Uma vez em obra, a equipe social inicia um trabalho de pósocupação no imóvel.

\section{Reunião inicial com os moradores do cortiço}

Essa reunião marca o início do trabalho de pósocupação 

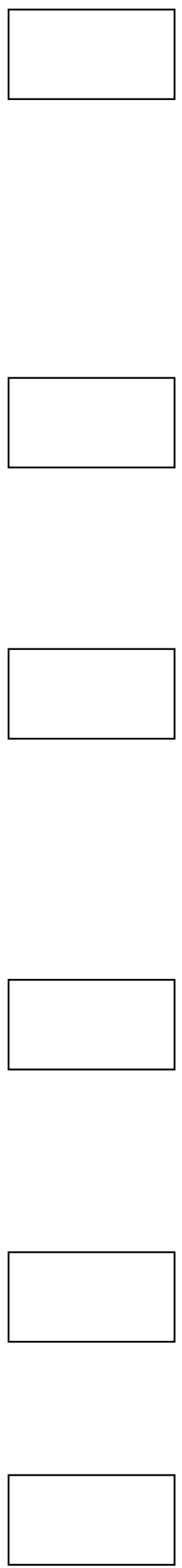

23

Reunião

de

reforço/Atividades

pedagógicas/Atividades de parceria

No geral, não há uma quantidade determinada de reuniões. Entretanto, há reuniões temáticas estabelecidas pelo Quadro Lógico do Programa, como, por exemplo, reuniões pedagógicas e atividades de parceria com instituições ou ONG's de capacitação e geração de renda.

\section{$2450 \%$ de reforma concluída}

Como metodologia do Programa de Cortiços, definiu-se que, uma vez alcançados $50 \%$ de serviços de obra de adequação, as famílias seriam encaminhadas para atendimentos habitacionais da CDHU.

\section{Início de atendimento habitacional da CDHU}

Embora o encaminhamento para a CDHU seja feito pela equipe social da $\mathrm{Habi}$, os atendimentos para acesso a uma unidade habitacional ou carta de crédito são realizados por equipes de assistentes socais do Programa de Ação em Cortiços da própria CDHU.

\section{Escolha de opções habitacionais}

As opções habitacionais da CDHU são unidades habitacionais ou cartas de crédito. Eventualmente são realizados atendimentos emergenciais na forma de concessão de verbas de apoio ou ajuda de custo.

\section{Atendimento às famílias}

Uma vez realizadas as opções habitacionais, as famílias passam a ter acompanhamento da equipe de assistentes sociais, tanto da CDHU como da Habi.

\section{Lacração do imóvel}

De acordo com as condições do imóvel encortiçado e com as decisões do proprietário, o imóvel pode vir a ser lacrado. 
A dinâmica da cidade impacta o desenvolvimento do Programa de Cortiços. Uma vez que os bairros se habituaram à presença das equipes do poder público, os hábitos dos moradores, proprietários de imóveis encortiçados e vizinhos em geral também mudaram. Ao iniciar as intimações e ao ver que as reformas davam frutos, as denúncias aumentaram, assim como a solicitação de visitas técnicas das equipes de arquitetos, engenheiros e assistentes sociais.

Cada sensível mudança no comportamento do bairro provocou mudanças também no fluxograma do Programa. Ajustes finos foram ocorrendo no passo a passo das atividades, de forma a melhorar tanto a eficiência quanto o atendimento às famílias moradoras de cortiços. 


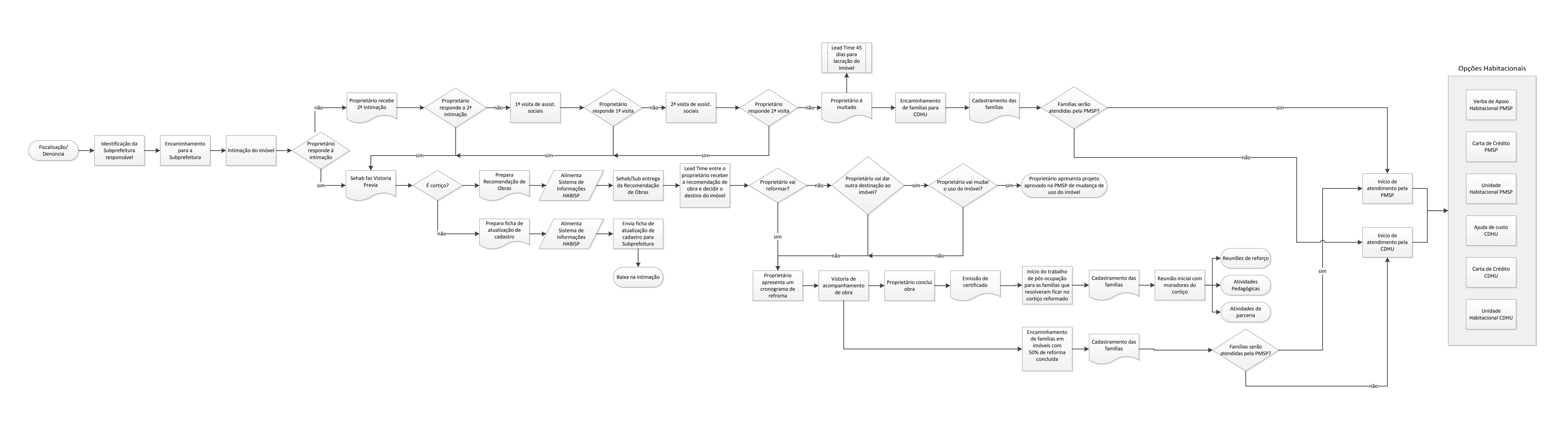




\section{Resultados do Programa de Cortiços}

O Relatório de Progresso do Programa de Cortiços teve início concomitante às primeiras intimações realizadas pela Subprefeitura da Mooca.

Inicialmente, o relatório apresentava dados baseados em previsões. Indicava a existência de 1.648 cortiços, pois adotava a informação do mapeamento de cortiços da CDHU.

Conforme o desenvolvimento das ações do Programa, o Relatório passou a misturar a previsão com o conhecimento adquirido através das intimações e vistorias realizadas. Durante os primeiros anos do Programa, mais da metade das informações era baseada em previsões.

Na primeira parte do Relatório, vemos dados gerais da área de atuação onde se dá o Programa, além de informações constantes no Censo de 2010 do IBGE. Na segunda parte, o Relatório apresenta dados gerais dos cortiços, como, por exemplo, a quantidade exata deles na área central, população moradora, etc. Em seguida, observamos dados gerenciais do Programa de Cortiços e a classificação das condições de habitabilidade.

Logo em seguida, o Relatório apresenta dados referentes aos avanços das obras e de caracterização das condições de habitabilidade dos cortiços. Em todos os casos, apresenta-se um total, na primeira coluna, referente à somatória dos dados das subprefeituras Sé e Mooca.

Os dados apresentados neste Relatório de Progresso referem-se ao mês de janeiro de 2011. 


\subsection{Dados gerais do Programa de Cortiços}

O Relatório apresenta em sua primeira página informações gerais referentes às áreas de atuação do Programa de Cortiços. Podemos observar dados relevantes, como a densidade da região por subprefeitura e a população de 640 mil habitantes (Tabela 14).

Tabela 14 - Dados gerais do Programa de Cortiços

\begin{tabular}{|c|c|c|c|c|}
\hline \multicolumn{5}{|c|}{ Identificação do Projeto } \\
\hline Equipe Envolvida: & SEHAB / HABI Centro & & & \\
\hline & $\mathrm{CDHU}$ & & & \\
\hline & & & & \\
\hline Área de Atuação: & Subprefeitura Mooca & & & \\
\hline & Subprefeitura Sé & & & \\
\hline & & & & \\
\hline & & & & \\
\hline & & & & \\
\hline \multicolumn{5}{|c|}{ Dados Gerais da Área de Atuação } \\
\hline \multicolumn{2}{|c|}{ Item } & Total & Sé & Mooca \\
\hline \multicolumn{2}{|l|}{ Área $\left(\mathrm{km}^{2}\right)$} & 61,40 & 26,20 & 35,20 \\
\hline \multicolumn{2}{|c|}{ Proporção em relação à área do Município } & $4,1 \%$ & $1,7 \%$ & $2,3 \%$ \\
\hline \multicolumn{2}{|l|}{ População } & 642.696 & 346.512 & 296.184 \\
\hline \multicolumn{2}{|c|}{ Proporção em relação à população do Município } & $5,8 \%$ & $3,1 \%$ & $2,7 \%$ \\
\hline \multicolumn{2}{|c|}{ Densidade média da região (hab/km²) } & $10.467,36$ & $13.225,65$ & $8.414,32$ \\
\hline \multicolumn{2}{|c|}{ Renda média da população (R\$) } & $1.640,25$ & $1.480,00$ & $1.800,50$ \\
\hline
\end{tabular}

Fonte: 3 - Censo de 2010 do IBGE.

Podemos observar que a população moradora em cortiços representa 2,6\% da população da Subprefeitura Sé, 2,3\% da população da Subprefeitura Mooca, resultando em 2,4\% da população total da área de abrangência do Programa de Cortiços, ou aproximadamente 15 mil moradores, ou 9 mil famílias (Tabela 15). 
Tabela 15 - Dados Relevantes dos Cortiços

\begin{tabular}{|c|c|c|c|}
\hline \multicolumn{2}{|c|}{ 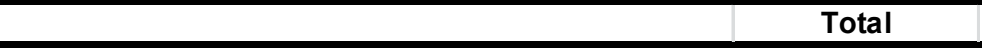 } & Sé & Mooca \\
\hline Número de cortiços em funcionamento & 996 & 601 & 395 \\
\hline Número de famílias & 9.376 & 5.732 & 3.644 \\
\hline População de moradores de cortiços & 15.710 & 8.864 & 6.846 \\
\hline Proporção em relação à população da região & $2,4 \%$ & $2,6 \%$ & $2,3 \%$ \\
\hline Média de famílias por imóvel & 10,84 & 11,35 & 10,12 \\
\hline Média de pessoas por família & 1,68 & 1,55 & 1,88 \\
\hline & & & \\
\hline Área média dos lotes $\left(\mathrm{m}^{2}\right)$ & 229 & 220 & 242 \\
\hline Soma das áreas de terreno $\left(\mathrm{m}^{2}\right)$ & 220.279 & 128.482 & 91.797 \\
\hline Área construída média dos imóveis $\left(\mathrm{m}^{2}\right)$ & 223 & 227 & 217 \\
\hline Soma das áreas construídas $\left(\mathrm{m}^{2}\right)$ & 215.012 & 132.657 & 82.355 \\
\hline Taxa de aproveitamento média dos terrenos & 0,98 & 1,03 & 0,90 \\
\hline Valor venal médio dos imóveis $(R \$$ & 203.815 & 223.381 & 174.004 \\
\hline Valor venal por $\mathrm{m}^{2}$ médio dos imóveis ( $\mathrm{R} \$$ ) & 891 & 1.015 & 718 \\
\hline Renda média da população de cortiços ( $R$ \$) & 755 & 786 & 711 \\
\hline Valor médio do aluguel $(\mathrm{R} \$)$ & 279 & 314 & 230 \\
\hline
\end{tabular}

Outro dado interessante é a quantidade de cortiços em funcionamento. Observou-se que, com o passar dos anos, desde 2001 uma significativa porcentagem dos endereços não correspondia mais a um cortiço. Outrossim, endereços que não constavam originalmente na lista passaram a ser utilizados como cortiços. Ou seja, as fiscalizações seguidas pelas vistorias, surpreendentemente para todas as equipes técnicas envolvidas, atualizaram o banco de dados da prefeitura, concluindo que, do total de 2.194 (Tabela 16) imóveis fiscalizados e vistoriados nas subprefeituras Sé e Mooca, aproximadamente 1.000 se enquadram na definição de cortiço estabelecida pela legislação.

\begin{tabular}{|c|c|c|c|c|c|c|}
\hline & Imoveis & $\%$ & Imoveis & $\%$ & Imoveıs & $\%$ \\
\hline Indicações recebidas & 2.194 & $100 \%$ & 1.328 & $100 \%$ & 866 & $100 \%$ \\
\hline Intimações efetuadas & 2.006 & $91 \%$ & 1.187 & $89 \%$ & 819 & $95 \%$ \\
\hline Vistorias prévias feitas & 1.921 & $88 \%$ & 1.086 & $82 \%$ & 835 & $96 \%$ \\
\hline Cortiços vistoriados & 1.168 & $53 \%$ & 708 & $53 \%$ & 460 & $53 \%$ \\
\hline Não cortiços vistoriados & 644 & $29 \%$ & 291 & $22 \%$ & 353 & $41 \%$ \\
\hline Invasões vistoriadas & 109 & $5 \%$ & 87 & $7 \%$ & 22 & $3 \%$ \\
\hline Indicações a vistoriar & 273 & $12 \%$ & 242 & $18 \%$ & 31 & $4 \%$ \\
\hline
\end{tabular}




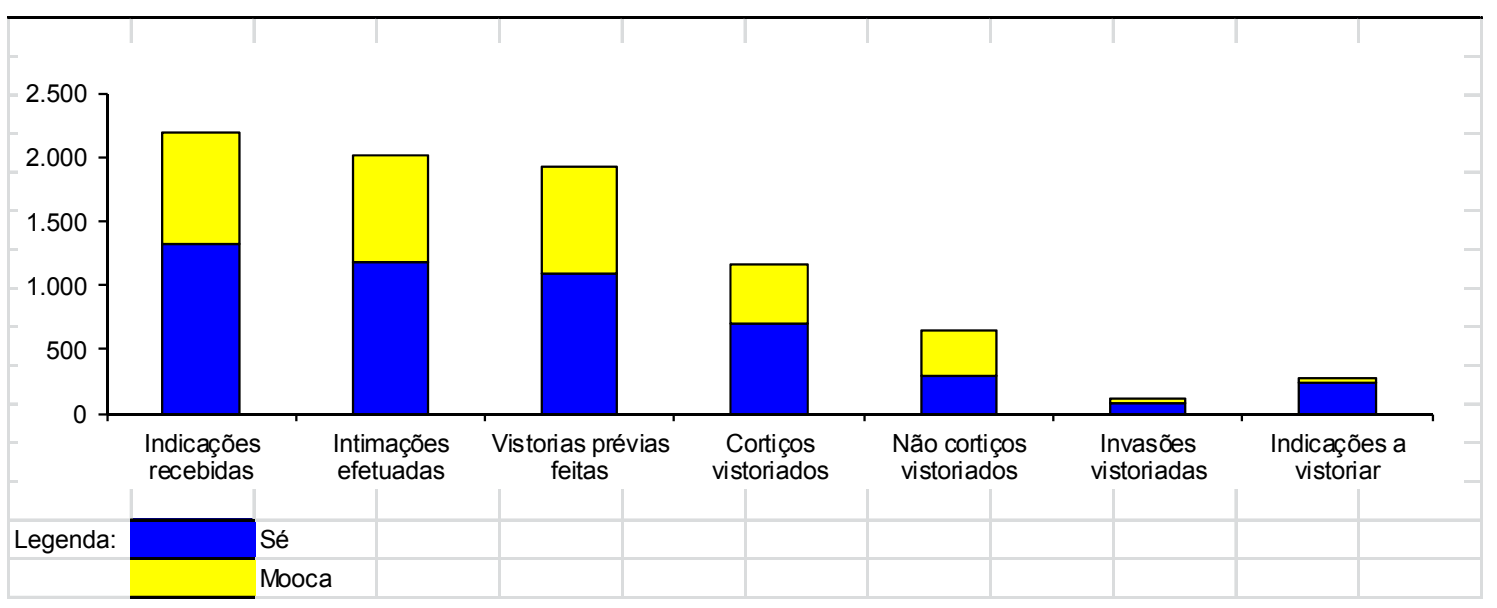

Gráfico 1 - Análise Gerencial do Programa

É importante notar que em um ambiente público, em se tratando de uma atividade que tem sua base em uma programação de fiscalização, as "Indicações Recebidas" (Tabela 16) referem-se ao mapeamento de cortiços cedido pela CDHU, somadas às solicitações de serviço feitas pelos munícipes através do portal ${ }^{42} \mathrm{da}$ Prefeitura de São Paulo disponível em ambiente web, assim como denúncias feitas por telefones ou na praça de atendimento das subprefeituras abrangidas pelo Programa de Cortiços, além da contribuição de movimentos de moradias engajados na questão social que envolvem os cortiços.

O Gráfico1, "Análise Gerencial do Programa”, indica a quantidade de 644 imóveis vistoriados e que não foram considerados cortiços segundo a Lei Moura, e também uma quantidade de 109 imóveis que foram identificados como imóveis invadidos (Tabela 17).

O gráfico indica ainda a quantidade de 273 imóveis que precisam entrar na programação de vistorias. Importante frisar que aparentemente são poucos os imóveis sem vistoria. Entretanto, computou-se um número de 2.959 famílias morando nesses imóveis, o que é percentualmente pouco, porém um contingente populacional alto que poderá estar em más condições de habitabilidade (Tabela 16).

\footnotetext{
${ }^{42}$ Portal da Prefeitura da Cidade de São Paulo www.capital.sp.gov.br
} 
Tabela 17 - Classificação dos Imóveis Vistoriados

\begin{tabular}{|l|c|c|c|c|c|c|}
\hline & \multicolumn{2}{c}{ Total } & \multicolumn{2}{c|}{ Sé } & \multicolumn{2}{c|}{ Mooca } \\
\hline & Imóveis & $\%$ & Imóveis & $\%$ & Imóveis & $\%$ \\
\hline Não cortiço & 644 & $34 \%$ & 291 & $27 \%$ & 353 & $42 \%$ \\
\hline Invasão & 109 & $6 \%$ & 87 & $8 \%$ & 22 & $3 \%$ \\
\hline Cortiço pequeno porte & 437 & $23 \%$ & 267 & $25 \%$ & 170 & $20 \%$ \\
\hline Cortiço médio porte & 433 & $23 \%$ & 245 & $23 \%$ & 188 & $23 \%$ \\
\hline Cortiço grande porte & 207 & $11 \%$ & 126 & $12 \%$ & 81 & $10 \%$ \\
\hline Cortiço interditável & 91 & $5 \%$ & 70 & $6 \%$ & 21 & $3 \%$ \\
\hline & & & & & & \\
\hline Total & 1.921 & $100 \%$ & 1.086 & $100 \%$ & 835 & $100 \%$ \\
\hline
\end{tabular}

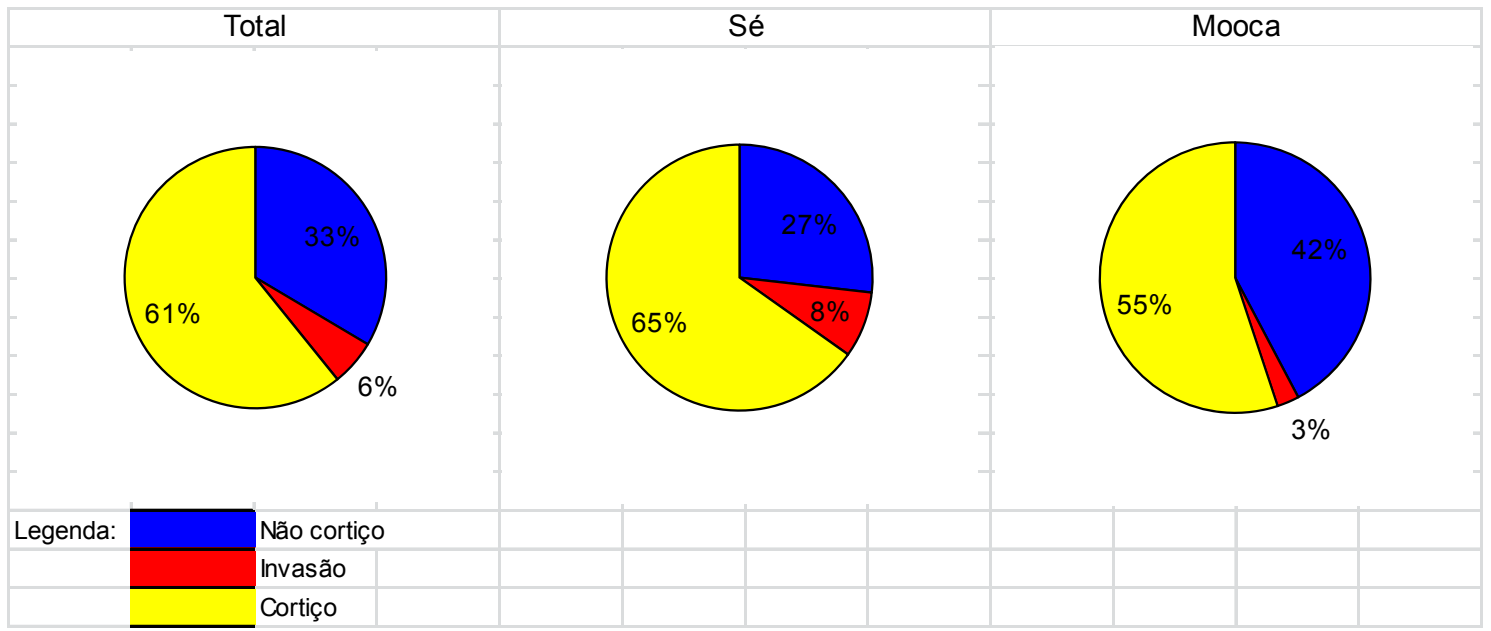

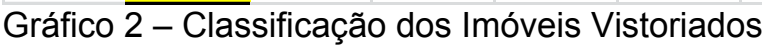

No gráfico "Classificação dos Imóveis Vistoriados" observamos as classificações por tipo de obra para a adequação do imóvel à Lei Moura. São três níveis relacionados ao volume de serviços de obra necessários à adequação dos imóveis.

Além dos níveis de obra, são observadas no relatório as classificações "não cortiço", equivalentes a imóveis que integravam anteriormente o mapeamento de cortiços da CDHU; porém, não se observa mais seu uso como cortiço. Além disso, as invasões recebem uma denominação à parte, tanto pelo poder público municipal quanto estadual, para evitar ondas de invasões nesse tipo de imóveis, motivada pela perspectiva oportunista dos invasores de receberem atendimentos habitacionais de quaisquer tipos disponíveis na Superintendência da Habitação Popular ou da CDHU.

No quadro a seguir, a análise gerencial do Programa informa a quantidade de cortiços vistoriados, que, subtraindo a quantidade de cortiços que tiveram seu uso modificado e a quantidade de cortiços interditados, nos dá a quantidade precisa de cortiços em funcionamento no centro da cidade de São Paulo (Tabela 18). Aqui, a 
primeira descoberta valiosa: dos 1.648 cortiços mapeados em 2001 pela CDHU, além de 546 denúncias de cortiços, apenas 996 imóveis foram identificados como cortiços em funcionamento.

Outras informações importantes são a quantidade de cortiços em obras de adequação e em mudança de uso. Notamos que, dos 996 cortiços em funcionamento, 748 encontram-se nessas condições, representando $75 \%$ do total de cortiços em funcionamento (Tabela 18).

Tabela 18 - Análise Gerencial dos Cortiços

\begin{tabular}{|c|c|c|c|c|c|}
\hline \multicolumn{2}{|c|}{ Total } & \multicolumn{2}{|c|}{ Sé } & \multicolumn{2}{|c|}{ Mooca } \\
\hline Imóveis & Famílias & Imóveis & Famílias & Imóveis & Famílias \\
\hline \multicolumn{6}{|c|}{ Total de cortiços vistoriados } \\
\hline 1.166 & 10.976 & 706 & 6.735 & 460 & 4.241 \\
\hline $100 \%$ & $100 \%$ & $100 \%$ & $100 \%$ & $100 \%$ & $100 \%$ \\
\hline \multirow{2}{*}{\multicolumn{6}{|c|}{ Mudanças de uso }} \\
\hline & & & & & \\
\hline 74 & 631 & 30 & 290 & 44 & 341 \\
\hline $6 \%$ & $6 \%$ & $4 \%$ & $4 \%$ & $10 \%$ & $8 \%$ \\
\hline \multicolumn{6}{|l|}{ Interditados } \\
\hline 96 & 969 & 75 & 713 & 21 & 256 \\
\hline $8 \%$ & $9 \%$ & $11 \%$ & $11 \%$ & $5 \%$ & $6 \%$ \\
\hline Subtotal de co & xtintos & & & & \\
\hline 170 & 1.600 & 105 & 1.003 & 65 & 597 \\
\hline $15 \%$ & $15 \%$ & $15 \%$ & $15 \%$ & $14 \%$ & $14 \%$ \\
\hline & & & & & \\
\hline Certificados & & & & & \\
\hline 7 & 36 & 2 & 2 & 5 & 34 \\
\hline $1 \%$ & $0 \%$ & $0 \%$ & $0 \%$ & $1 \%$ & $1 \%$ \\
\hline Em adequaçãc & & & & & \\
\hline 748 & 7.315 & 441 & 4.390 & 307 & 2.925 \\
\hline $64 \%$ & $67 \%$ & $62 \%$ & $65 \%$ & $67 \%$ & $69 \%$ \\
\hline Em adequaçãc & ança de us & & & & \\
\hline 11 & 119 & 0 & 0 & 11 & 119 \\
\hline $1 \%$ & $1 \%$ & $0 \%$ & $0 \%$ & $2 \%$ & $3 \%$ \\
\hline Sem resposta & onsável & & & & \\
\hline 230 & 1.906 & 158 & 1.340 & 72 & 566 \\
\hline $20 \%$ & $17 \%$ & $22 \%$ & $20 \%$ & $16 \%$ & $13 \%$ \\
\hline Subtotal de co & m funciona & & & & \\
\hline 996 & 9.376 & 601 & 5.732 & 395 & 3.644 \\
\hline $85 \%$ & $85 \%$ & $85 \%$ & $85 \%$ & $86 \%$ & $86 \%$ \\
\hline
\end{tabular}




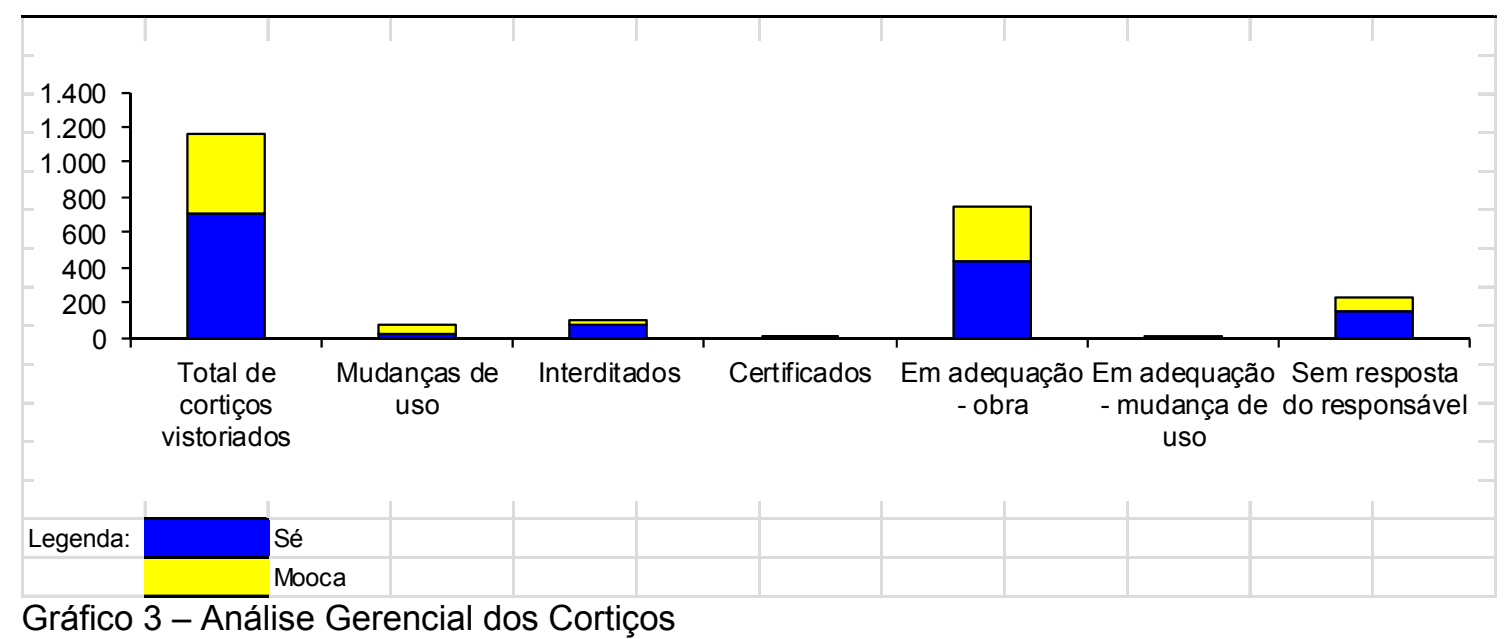

Observamos ainda que a quantidade de cortiços interditados excede a quantidade de cortiços classificados como interditáveis. Isso se explica pelo fato de a equipe de gestão do Programa ter autonomia nas decisões frente às realidades encontradas nas vistorias, adotando as classificações dos cortiços como mero guia para as intervenções do Programa, e não como regra inflexível.

Vale lembrar que cortiços classificados como Grande Porte de obra para adequação podem estar no limiar da interdição, sendo sua condição de habitabilidade altamente suscetível a condições adversas, como tempestades, alagamentos, ou mesmo a intervenções dos próprios moradores, que, sem orientação técnica, podem chegar a piorar as condições internas dos imóveis.

Abaixo, encontramos a distribuição de cortiços nos distritos das subprefeituras Sé e Mooca. Podemos observar a predominância dos cortiços nos distritos mais centrais, como Brás, Bela Vista, Liberdade e Belém: 
Tabela 19 - Distribuição dos Cortiços por Distrito de Subprefeitura

\begin{tabular}{|c|c|c|c|c|c|}
\hline Subprefeitura & \multirow{2}{*}{$\begin{array}{c}\text { Distrito } \\
\text { Bela Vista }\end{array}$} & Imóveis & $\%$ & Famílias & $\%$ \\
\hline \multirow{8}{*}{ Sé } & & 153 & $15 \%$ & 1.750 & $19 \%$ \\
\hline & Bom Retiro & 77 & $8 \%$ & 480 & $5 \%$ \\
\hline & Cambuci & 51 & $5 \%$ & 406 & $4 \%$ \\
\hline & Consolação & 0 & $0 \%$ & 0 & $0 \%$ \\
\hline & Liberdade & 136 & $14 \%$ & 1.214 & $13 \%$ \\
\hline & República & 46 & $5 \%$ & 459 & $5 \%$ \\
\hline & Santa Cecília & 101 & $10 \%$ & 1.125 & $12 \%$ \\
\hline & Sé & 37 & $4 \%$ & 298 & $3 \%$ \\
\hline & & & & & \\
\hline \multirow{9}{*}{ Mooca } & Água Rasa & 15 & $2 \%$ & 96 & $1 \%$ \\
\hline & Belém & 115 & $12 \%$ & 994 & $11 \%$ \\
\hline & Brás & 158 & $16 \%$ & 1.858 & $20 \%$ \\
\hline & Carrão & 0 & $0 \%$ & 0 & $0 \%$ \\
\hline & Mooca & 60 & $6 \%$ & 365 & $4 \%$ \\
\hline & Pari & 44 & $4 \%$ & 316 & $3 \%$ \\
\hline & Tatuapé & 3 & $0 \%$ & 15 & $0 \%$ \\
\hline & Vila Formosa & 0 & $0 \%$ & 0 & $0 \%$ \\
\hline & Vila Prudente & 0 & $0 \%$ & 0 & $0 \%$ \\
\hline \multirow{2}{*}{ Total } & & 096 & $100 \%$ & 9376 & $100 \%$ \\
\hline & & 996 & $100 \%$ & $9.3 / 6$ & $100 \%$ \\
\hline
\end{tabular}

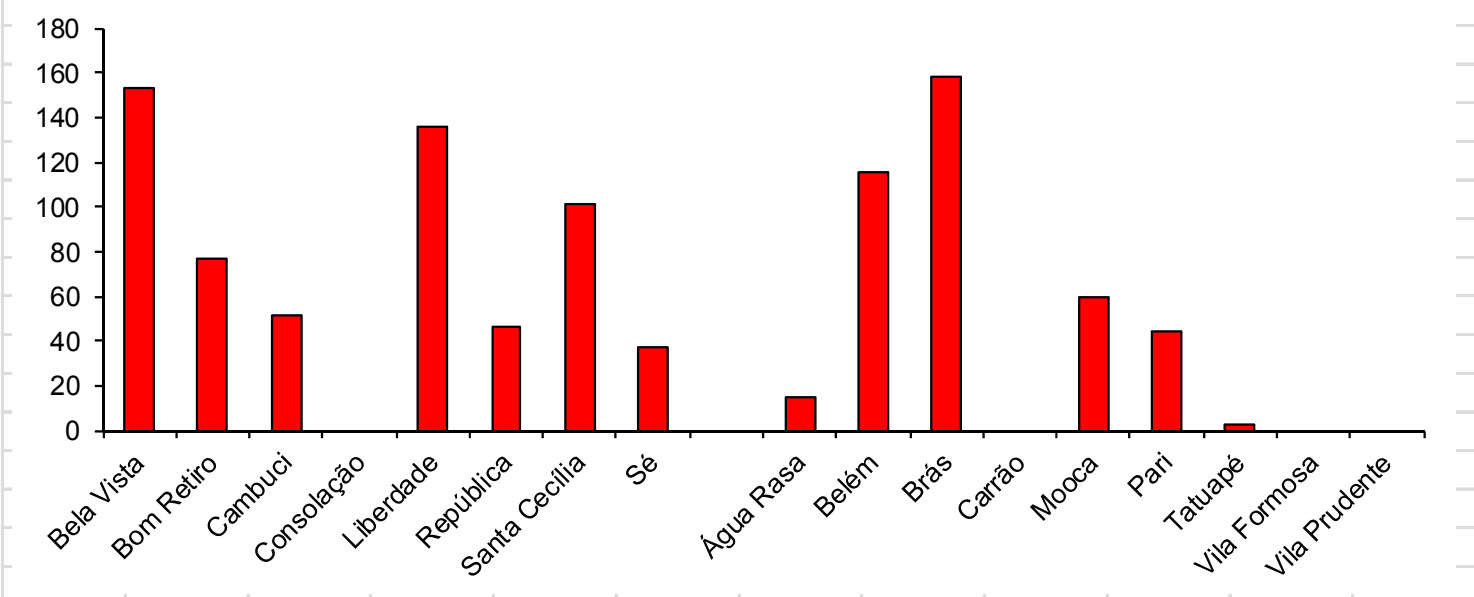

Gráfico 4 - Distribuição dos Cortiços por Distrito de Subprefeitura 


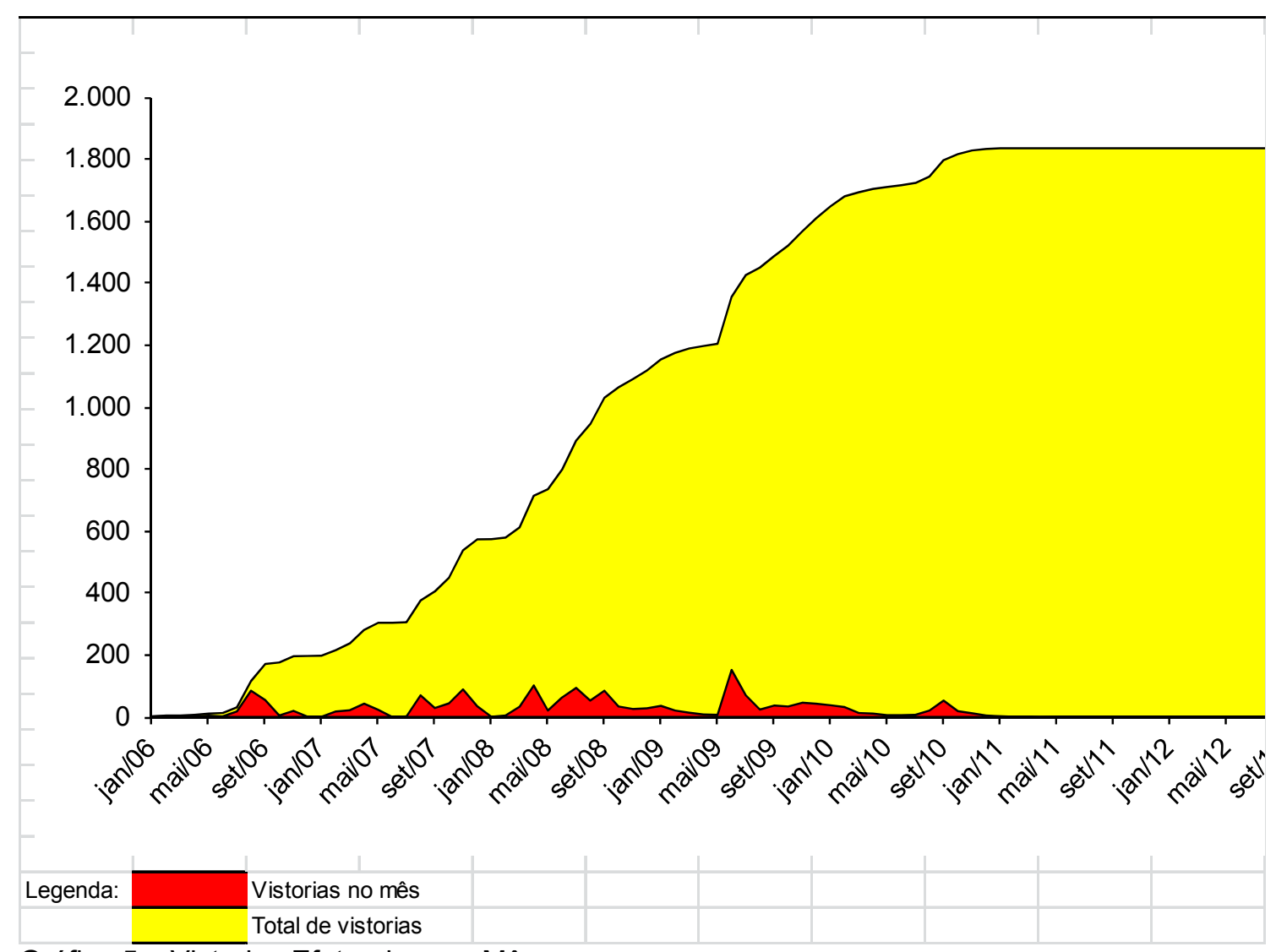

Gráfico 5 - Vistorias Efetuadas por Mês

O gráfico acima demostra o ritmo de vistorias realizado em imóveis pela equipe de gestão do Programa desde o mês de maio de 2006. Vemos que o quadrimestre mais intenso foi entre maio e setembro de 2009, alcançando ao todo 1.921 vistorias (Tabela 16).

Como vimos anteriormente no item 2.6, de acordo com sua nota de priorização os cortiços estão distribuídos em três classificações de obra e uma de interdição. As piores condições, que são as situações de interdição e os cortiços classificados como Grande Porte de obra para sua adequação à Lei Moura, representam juntos $26 \%$ (Tabela 20 ) do total de imóveis vistoriados, equivalendo a 3.321 famílias em péssimas condições de habitabilidade.

Segundo informações do Programa, 2.798 famílias foram atendidas em soluções habitacionais do Programa de Cortiços, seja pelas reformas de adequação à Lei Moura, seja pelo encaminhamento ao Programa de Carta de Crédito ou ao Comercialização de Unidades Habitacionais, ambos da CDHU. 
Tabela 20 - Porte de obra dos cortiços vistoriados.

Total de cortiços vistoriados: 1168

\begin{tabular}{|c|c|c|c|c|c|c|}
\hline \multicolumn{3}{|c|}{ Total } & \multicolumn{2}{|c|}{ Sé } & \multicolumn{2}{|c|}{ Mooca } \\
\hline \multirow{2}{*}{$\begin{array}{c}\text { Imóveis } \\
\text { Pequeno Porte }\end{array}$} & & Famílias & Imóveis & Famílias & Imóveis & Famílias \\
\hline & & & & & & \\
\hline 437 & & 3.464 & 267 & 2.108 & 170 & 1.356 \\
\hline $37 \%$ & $r$ & $37 \%$ & $38 \%$ & $37 \%$ & $37 \%$ & $37 \%$ \\
\hline Médio Porte & & & & & & \\
\hline 433 & & 4.191 & 245 & 2.442 & 188 & 1.749 \\
\hline $37 \%$ & $F$ & $45 \%$ & $35 \%$ & $43 \%$ & $41 \%$ & $48 \%$ \\
\hline Grande Porte & & & & & & \\
\hline 207 & & 2.410 & 126 & 1.526 & 81 & 884 \\
\hline $18 \%$ & $r$ & $26 \%$ & $18 \%$ & $27 \%$ & $17 \%$ & $24 \%$ \\
\hline Interditável & & & & & & \\
\hline 91 & & 911 & 70 & 659 & 21 & 252 \\
\hline $8 \%$ & T & $10 \%$ & $10 \%$ & $11 \%$ & $5 \%$ & $7 \%$ \\
\hline
\end{tabular}

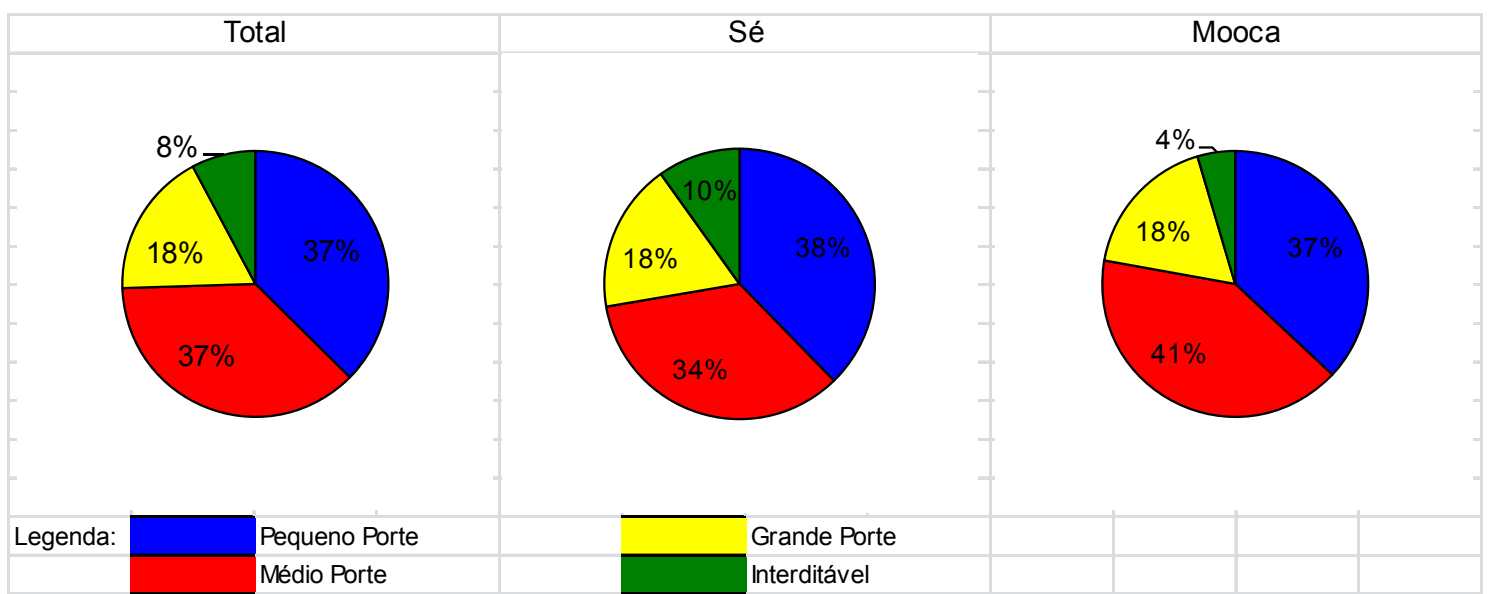

Gráfico 6 - Porte de Reforma dos Cortiços Vistoriados

O gráfico a seguir, da mesma forma que o anterior, representa as classificações dos imóveis, desta vez por índice de priorização, considerando, por exemplo, que os cortiços de Grande Porte de obra são aqueles com índice menor que 0,25 (Tabela 21). 
Tabela 21 - Índices de Adequação das Vistorias Prévias

Total de cortiços vistoriados: 1168

\begin{tabular}{|c|c|c|c|c|c|}
\hline \multicolumn{2}{|c|}{ Total } & \multicolumn{2}{|c|}{ Sé } & \multicolumn{2}{|c|}{ Mooca } \\
\hline Imóveis & Famílias & Imóveis & Famílias & Imóveis & Famílias \\
\hline \multicolumn{6}{|l|}{ Igual a 1} \\
\hline 4 & 22 & 1 & 2 & 3 & 20 \\
\hline $0 \%$ & $0 \%$ & $0 \%$ & $0 \%$ & $1 \%$ & $1 \%$ \\
\hline \multicolumn{6}{|l|}{ De 0,75 a 0,99} \\
\hline 232 & 2081 & 135 & 1116 & 97 & 965 \\
\hline $20 \%$ & $22 \%$ & $19 \%$ & $19 \%$ & $21 \%$ & $26 \%$ \\
\hline \multicolumn{6}{|l|}{ De 0,50 a 0,75} \\
\hline 530 & 5012 & 318 & 3099 & 212 & 1913 \\
\hline $45 \%$ & $53 \%$ & $45 \%$ & $54 \%$ & $46 \%$ & $52 \%$ \\
\hline \multicolumn{6}{|l|}{ De 0,25 a 0,50} \\
\hline 278 & 2742 & 169 & 1810 & 109 & 932 \\
\hline $24 \%$ & $25 \%$ & $24 \%$ & $27 \%$ & $24 \%$ & $22 \%$ \\
\hline Menor que 0,25 & & & & & \\
\hline 124 & 1119 & 85 & 708 & 39 & 411 \\
\hline $11 \%$ & $10 \%$ & $12 \%$ & $11 \%$ & $8 \%$ & $10 \%$ \\
\hline
\end{tabular}

Legenda: Sé

Gráfico 7 - Índices de Adequação das Vistorias Prévias

Vale aqui esclarecer o motivo de a equipe de gestão do Programa, manter duas informações referentes à classificação dos imóveis, uma por tipo de obra de adequação e outra por índice de priorização.

Em 2006, quando se deu o início ao trabalho de construção do Sistema de Informações, o Programa de Cortiços já operava com a nomenclatura de classificação segundo o porte das obras. Uma vez o Sistema construído e em operação, todos os programas habitacionais da Habi passaram a utilizar os índices de priorização. No caso da classificação por porte de obra, há quatro níveis de intervenção nos imóveis, enquanto que a classificação por índice de priorização leva uma nota entre zero e 1. 
Uma opção teria sido construir um quadro de equivalências entre os dois modos de classificação; entretanto, a equipe de gestão do Programa optou por manter as duas informações.

Considerando o trabalho social em desenvolvimento nos imóveis, a classificação por porte de obra é mais didática e se mostra mais esclarecedora em reuniões com os moradores de cortiços.

\subsection{Tipologia dos cortiços}

Os dados levantados no instrumental Vistoria Prévia tem, nos dados gerais dos imóveis (Tabela 4) que nos possibilitam traçar o perfil predominante dos imóveis que são cortiços no centro da cidade de São Paulo.

Dados como tipologia da construção, testada dos lotes, profundidade e área dos terrenos, área construída e ano de construção nos dão um perfil da tipologia mais recorrente nos cortiços.

O Relatório aponta que $90 \%$ dos cortiços são casas térreas ou sobrados em lotes cuja testada de até 5 metros de comprimento ocorre em $20 \%$ dos casos e testada até 10 metros, em $67 \%$ dos casos (Tabela 22).

A profundidade dos terrenos é também um dado importante, uma vez que o comprimento é característico do parcelamento de determinada época. Em geral, lotes antigos não apresentam uma qualidade econômica contemporânea. Pertencem a uma lógica de mercado de outra época, sendo a consequência direta dessa situação a desvalorização do lote em função de suas dimensões. Contrário ao lote moderno de 10 ou 5 metros de testada por 25 metros de comprimento, 67\% dos cortiços apresentam mais de 25 metros de comprimento/profundidade (Tabela 24). 0 valor do IPTU ${ }^{43}$ desses imóveis varia de $\mathrm{R} \$ 400,00$ a $\mathrm{R} \$ 800,00$ em $43 \%$ dos casos e de $R \$ 800,00$ a $R \$ 1.200,00$ em $30 \%$ (Tabela 28 ).

\footnotetext{
${ }^{43}$ Imposto Predial Territorial Urbano (IPTU).
} 
Por consequência, a área do terreno também é representativa da época. Em $57 \%$ dos casos, os terrenos têm entre 100 e $250 \mathrm{~m}^{2}$ de área. $\mathrm{E}$, em $28 \%$ dos casos, área entre 250 e $500 \mathrm{~m}^{2}$ (Tabela 25). A área construída no lote segue os mesmos padrões: de 100 a $250 \mathrm{~m}^{2}, 51 \%$; e de 250 a $500 \mathrm{~m}^{2}, 21 \%$ (Tabela 26).

Em relação ao ano de construção observamos que $72 \%$ dos cortiços foram construídos antes de 1960 (Tabela 27).

Especificamente no quadro abaixo, observamos que os dados são referentes a 974 cortiços em funcionamento, e não 996, como nos demais gráficos.

A diferença de 22 cortiços é reflexo da falta de dados no cadastro da prefeitura. Embora possa aparentar uma possível inconsistência de dados, podemos concluir que percentualmente não há diferenças significativas entre os dados.

Tabela 22 - Caracterização dos Lotes - Tipologia da Edificação Total de cortiços em funcionamento: 974

\begin{tabular}{|c|c|c|c|c|c|}
\hline \multicolumn{2}{|c|}{ Total } & \multicolumn{2}{|c|}{ Sé } & \multicolumn{2}{|c|}{ Mooca } \\
\hline Imóveis & Famílias & Imóveis & Famílias & Imóveis & Famílias \\
\hline \multicolumn{6}{|l|}{ Casa térrea } \\
\hline 259 & 1.970 & 125 & 954 & 134 & 1.016 \\
\hline $26 \%$ & $21 \%$ & $21 \%$ & $17 \%$ & $34 \%$ & $28 \%$ \\
\hline \multicolumn{6}{|l|}{ Sobrado } \\
\hline 638 & 6.079 & 420 & 3.947 & 218 & 2.132 \\
\hline $64 \%$ & $65 \%$ & $70 \%$ & $69 \%$ & $55 \%$ & $59 \%$ \\
\hline \multicolumn{6}{|c|}{ Três pavimentos ou mais } \\
\hline 62 & 1.015 & 42 & 629 & 20 & 386 \\
\hline $6 \%$ & $11 \%$ & $7 \%$ & $11 \%$ & $5 \%$ & $11 \%$ \\
\hline \multicolumn{6}{|l|}{ Não vistoriado } \\
\hline 15 & 30 & 2 & 12 & 13 & 18 \\
\hline $2 \%$ & $0 \%$ & $0 \%$ & $0 \%$ & $3 \%$ & $0 \%$ \\
\hline
\end{tabular}

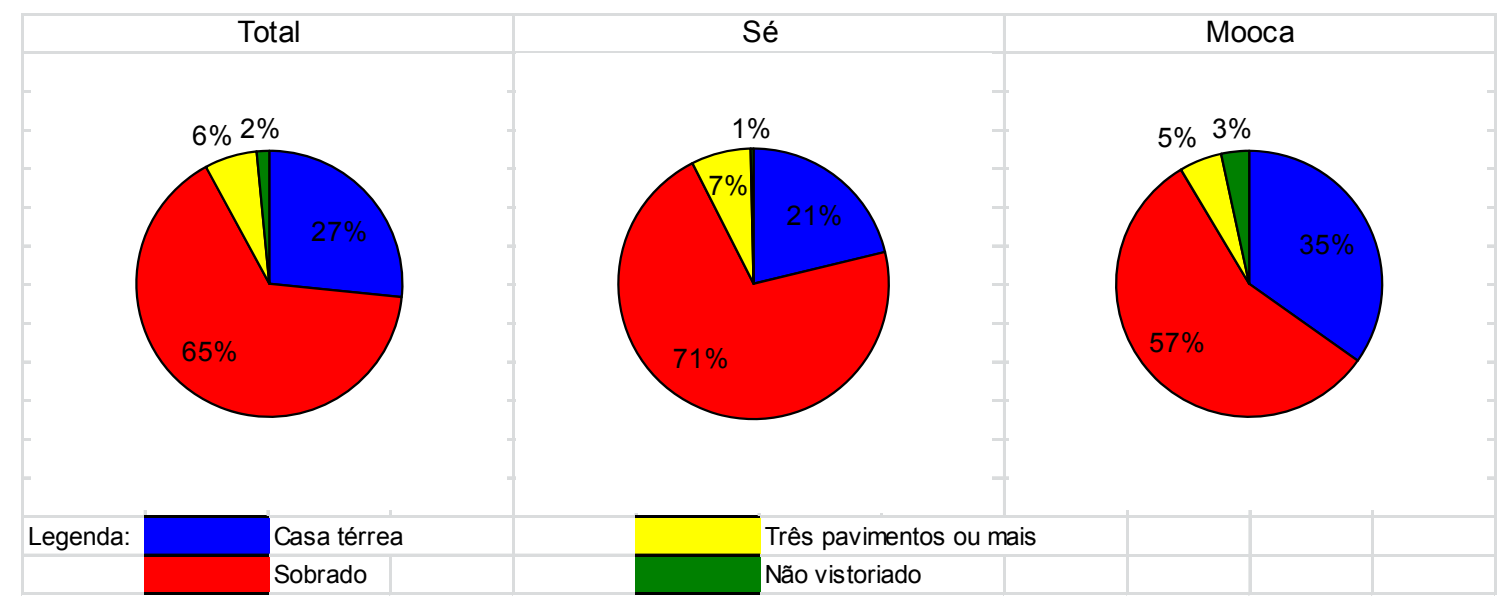

Gráfico 8 - Caracterização dos Lotes - Tipologia da Edificação 
Tabela 23 - Caracterização dos Lotes - Testada

Total de cortiços em funcionamento: 996

\begin{tabular}{|c|c|c|c|c|c|}
\hline \multicolumn{2}{|c|}{ Total } & \multicolumn{2}{|c|}{ Sé } & \multicolumn{2}{|c|}{ Mooca } \\
\hline Imóveis & Famílias & Imóveis & Famílias & Imóveis & Famílias \\
\hline \multicolumn{6}{|l|}{ Até 5 m } \\
\hline 204 & 1.648 & 90 & 694 & 114 & 954 \\
\hline $20 \%$ & $18 \%$ & $15 \%$ & $12 \%$ & $29 \%$ & $26 \%$ \\
\hline \multicolumn{6}{|l|}{ De $5 \mathrm{~m}$ a $10 \mathrm{~m}$} \\
\hline 666 & 6.402 & 435 & 4.142 & 231 & 2.260 \\
\hline $67 \%$ & $68 \%$ & $72 \%$ & $72 \%$ & $58 \%$ & $62 \%$ \\
\hline \multicolumn{6}{|c|}{ De $10 \mathrm{~m}$ a $15 \mathrm{~m}$} \\
\hline 57 & 583 & 37 & 466 & 20 & 117 \\
\hline $6 \%$ & $6 \%$ & $6 \%$ & $8 \%$ & $5 \%$ & $3 \%$ \\
\hline \multicolumn{6}{|c|}{ De $15 \mathrm{~m}$ a $20 \mathrm{~m}$} \\
\hline 15 & 228 & 8 & 154 & 7 & 74 \\
\hline $2 \%$ & $2 \%$ & $1 \%$ & $3 \%$ & $2 \%$ & $2 \%$ \\
\hline \multicolumn{6}{|l|}{ Mais de $20 \mathrm{~m}$} \\
\hline 16 & 191 & 9 & 130 & 7 & 61 \\
\hline $2 \%$ & $2 \%$ & $1 \%$ & $2 \%$ & $2 \%$ & $2 \%$ \\
\hline \multicolumn{6}{|l|}{ Não verificado } \\
\hline 38 & 324 & 22 & 146 & 16 & 178 \\
\hline $4 \%$ & $3 \%$ & $4 \%$ & $3 \%$ & $4 \%$ & $5 \%$ \\
\hline
\end{tabular}

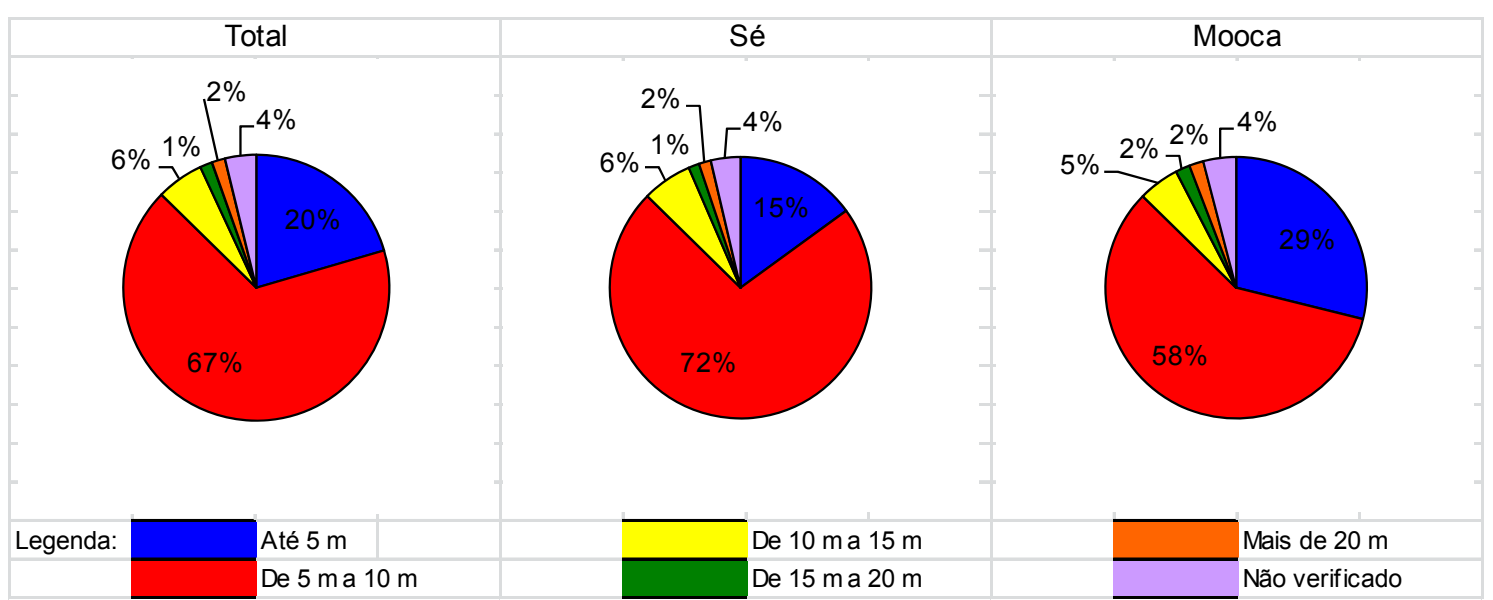

Gráfico 9 - Caracterização dos Lotes - Testada 
Tabela 24 - Caracterização dos Lotes - Profundidade

Total de cortiços em funcionamento: 996

\begin{tabular}{|c|c|c|c|c|c|}
\hline \multicolumn{2}{|c|}{ Total } & \multicolumn{2}{|c|}{ Sé } & \multicolumn{2}{|c|}{ Mooca } \\
\hline Imóveis & Famílias & Imóveis & Famílias & Imóveis & Famílias \\
\hline \multicolumn{6}{|l|}{ Até 25 m } \\
\hline 284 & 2.000 & 210 & 1.482 & 74 & 518 \\
\hline $29 \%$ & $21 \%$ & $35 \%$ & $26 \%$ & $19 \%$ & $14 \%$ \\
\hline \multicolumn{6}{|c|}{ De $25 \mathrm{~m}$ a $30 \mathrm{~m}$} \\
\hline 181 & 1.685 & 105 & 1.116 & 76 & 569 \\
\hline $18 \%$ & $18 \%$ & $17 \%$ & $19 \%$ & $19 \%$ & $16 \%$ \\
\hline \multicolumn{6}{|c|}{ De $30 \mathrm{~m}$ a $35 \mathrm{~m}$} \\
\hline 117 & 1.166 & 70 & 747 & 47 & 419 \\
\hline $12 \%$ & $12 \%$ & $12 \%$ & $13 \%$ & $12 \%$ & $11 \%$ \\
\hline \multicolumn{6}{|c|}{ De $35 \mathrm{~m}$ a $40 \mathrm{~m}$} \\
\hline 131 & 1.384 & 70 & 779 & 61 & 605 \\
\hline $13 \%$ & $15 \%$ & $12 \%$ & $14 \%$ & $15 \%$ & $17 \%$ \\
\hline \multicolumn{6}{|l|}{ Mais de $40 \mathrm{~m}$} \\
\hline 239 & 2.772 & 124 & 1.462 & 115 & 1.310 \\
\hline $24 \%$ & $30 \%$ & $21 \%$ & $26 \%$ & $29 \%$ & $36 \%$ \\
\hline \multicolumn{6}{|l|}{ Não verificado } \\
\hline 44 & 369 & 22 & 146 & 22 & 223 \\
\hline $4 \%$ & $4 \%$ & $4 \%$ & $3 \%$ & $6 \%$ & $6 \%$ \\
\hline
\end{tabular}

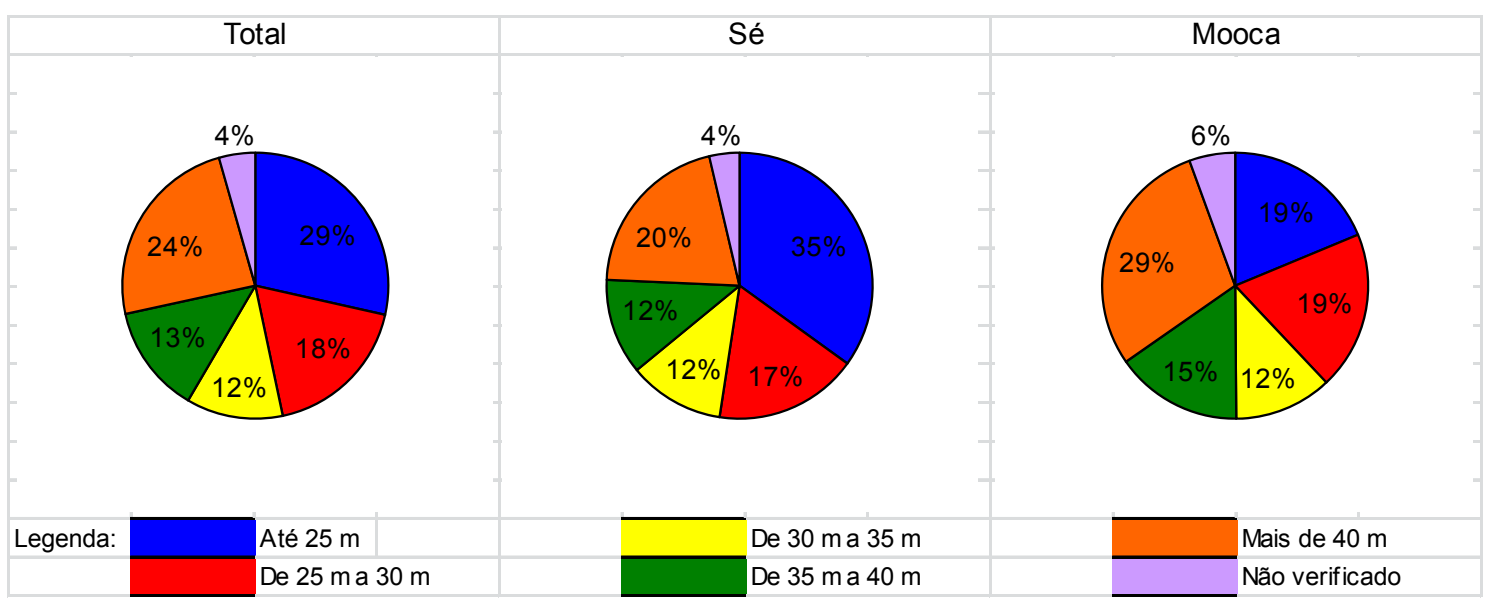

Gráfico 10 - Caracterização dos Lotes - Profundidade 
Tabela 25 - Caracterização dos Lotes - Área do Terreno

Total de cortiços em funcionamento: 996

\begin{tabular}{|c|c|c|c|c|c|}
\hline \multicolumn{2}{|c|}{ Total } & \multicolumn{2}{|c|}{ Sé } & \multicolumn{2}{|c|}{ Mooca } \\
\hline Imóveis & Famílias & Imóveis & Famílias & Imóveis & \multirow[t]{2}{*}{ Famílias } \\
\hline Até $100 \mathrm{~m}^{2}$ & & & & & \\
\hline 93 & 571 & 75 & 465 & 18 & 106 \\
\hline $9 \%$ & $6 \%$ & $12 \%$ & $8 \%$ & $5 \%$ & $3 \%$ \\
\hline \multicolumn{6}{|c|}{ De $100 \mathrm{~m}^{2}$ a $250 \mathrm{~m}^{2}$} \\
\hline 563 & 4.755 & 336 & 2.849 & 227 & 1.906 \\
\hline $57 \%$ & $51 \%$ & $56 \%$ & $50 \%$ & $57 \%$ & $52 \%$ \\
\hline \multicolumn{6}{|c|}{ De $250 \mathrm{~m}^{2}$ a $500 \mathrm{~m}^{2}$} \\
\hline 275 & 3.245 & 158 & 1.988 & 117 & 1.257 \\
\hline $28 \%$ & $35 \%$ & $26 \%$ & $35 \%$ & $30 \%$ & $34 \%$ \\
\hline \multicolumn{6}{|c|}{ De $500 \mathrm{~m}^{2}$ a $750 \mathrm{~m}^{2}$} \\
\hline 25 & 394 & 11 & 238 & 14 & 156 \\
\hline $3 \%$ & $4 \%$ & $2 \%$ & $4 \%$ & $4 \%$ & $4 \%$ \\
\hline \multicolumn{6}{|c|}{ Maior que $750 \mathrm{~m}^{2}$} \\
\hline 7 & 136 & 4 & 100 & 3 & 36 \\
\hline $1 \%$ & $1 \%$ & $1 \%$ & $2 \%$ & $1 \%$ & $1 \%$ \\
\hline \multicolumn{6}{|l|}{ Não verificado } \\
\hline 33 & 275 & 17 & 92 & 16 & 183 \\
\hline $3 \%$ & $3 \%$ & $3 \%$ & $2 \%$ & $4 \%$ & $5 \%$ \\
\hline
\end{tabular}

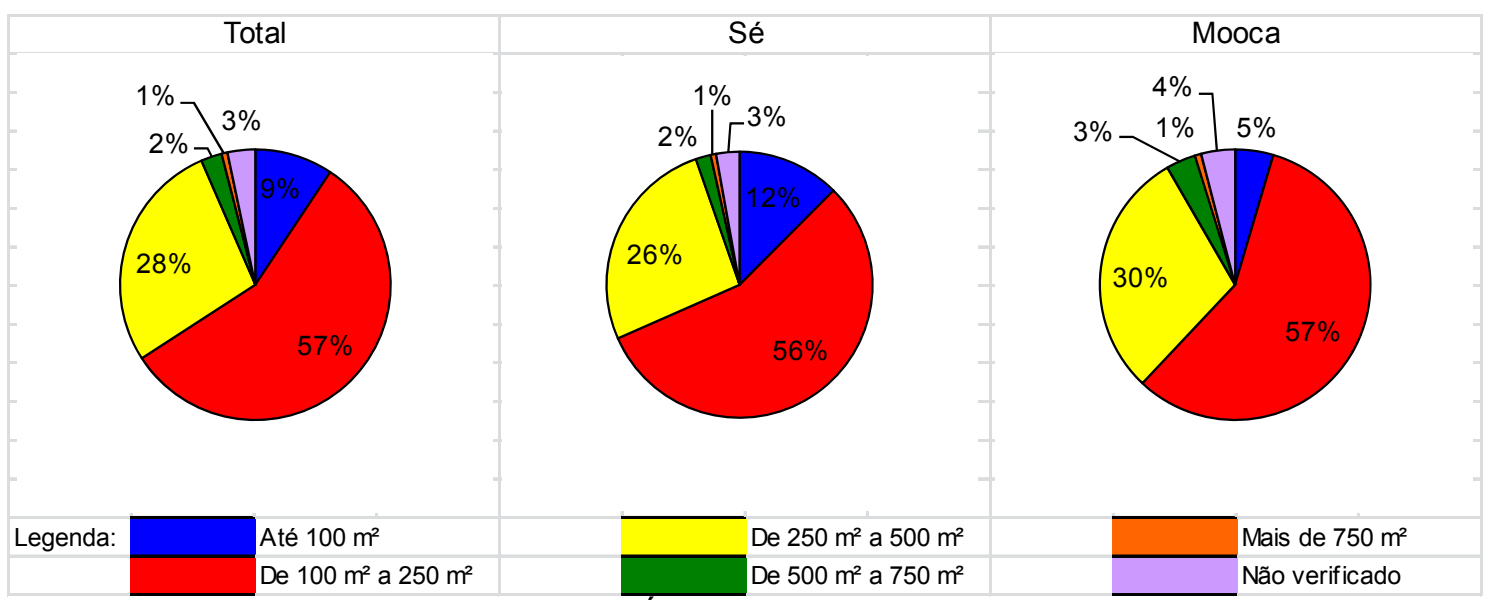

Gráfico 11 - Caracterização dos Lotes - Área do Terreno 
Tabela 26 - Caracterização dos Lotes - Área Construída

Total de cortiços em funcionamento: 996

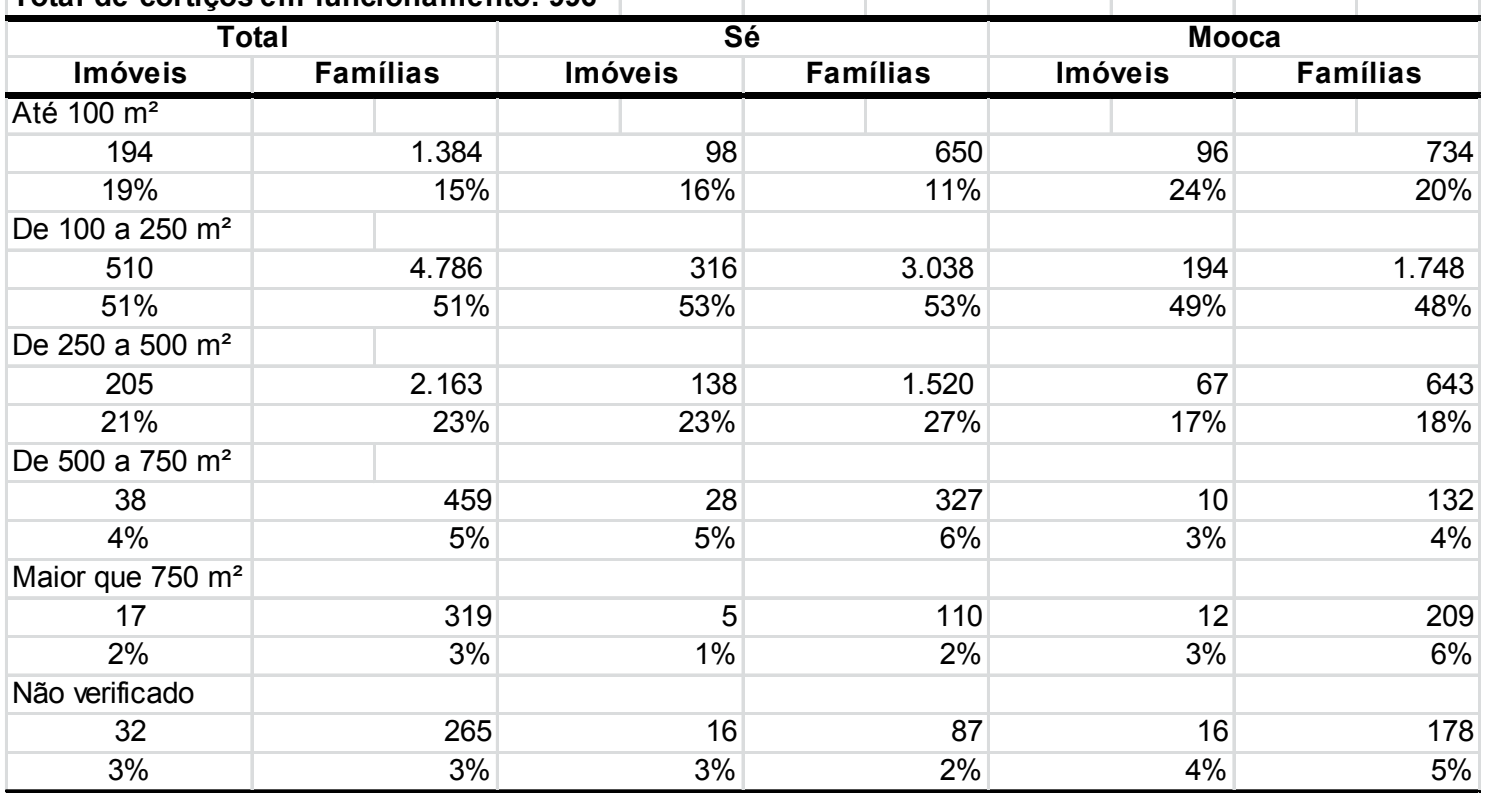

\begin{tabular}{|l|l|l|l|}
\hline & Sé \\
\hline Legenda: & Até $100 \mathrm{~m}^{2}$ & Deoca \\
De $100 \mathrm{~m}^{2}$ a $250 \mathrm{~m}^{2}$ & De $500 \mathrm{~m}^{2}$ a $750 \mathrm{~m}^{2}$ & Nais de $750 \mathrm{~m}^{2}$ \\
\hline
\end{tabular}

Gráfico 12 - Caracterização dos Lotes - Área Construída 
Tabela 27 - Dados Cadastrais dos Imóveis - Ano de Construção

Total de cortiços em funcionamento: 996

\begin{tabular}{|c|c|c|c|c|c|}
\hline \multicolumn{2}{|c|}{ Total } & \multicolumn{2}{|c|}{ Sé } & \multicolumn{2}{|c|}{ Mooca } \\
\hline Imóveis & Famílias & Imóveis & Famílias & Imóveis & \multirow[t]{2}{*}{ Famílias } \\
\hline Anterior a 1930 & & & & & \\
\hline 65 & 644 & 36 & 377 & 29 & 267 \\
\hline $7 \%$ & $7 \%$ & $6 \%$ & $7 \%$ & $7 \%$ & $7 \%$ \\
\hline \multicolumn{6}{|c|}{ Décadas de 1930 e 1940} \\
\hline 430 & 4.280 & 272 & 2.695 & 158 & 1.585 \\
\hline $43 \%$ & $46 \%$ & $45 \%$ & $47 \%$ & $40 \%$ & $43 \%$ \\
\hline \multicolumn{6}{|c|}{ Décadas de 1950 e 1960} \\
\hline 216 & 2.003 & 104 & 1.048 & 112 & 955 \\
\hline $22 \%$ & $21 \%$ & $17 \%$ & $18 \%$ & $28 \%$ & $26 \%$ \\
\hline \multicolumn{6}{|c|}{ Décadas de 1970 e 1980} \\
\hline 218 & 1.949 & 151 & 1.396 & 67 & 553 \\
\hline $22 \%$ & $21 \%$ & $25 \%$ & $24 \%$ & $17 \%$ & $15 \%$ \\
\hline \multicolumn{6}{|l|}{ Posterior a 1990} \\
\hline 31 & 216 & 17 & 101 & 14 & 115 \\
\hline $3 \%$ & $2 \%$ & $3 \%$ & $2 \%$ & $4 \%$ & $3 \%$ \\
\hline \multicolumn{6}{|l|}{ Não verificado } \\
\hline 36 & 284 & 21 & 115 & 15 & 169 \\
\hline $4 \%$ & $3 \%$ & $3 \%$ & $2 \%$ & $4 \%$ & $5 \%$ \\
\hline
\end{tabular}

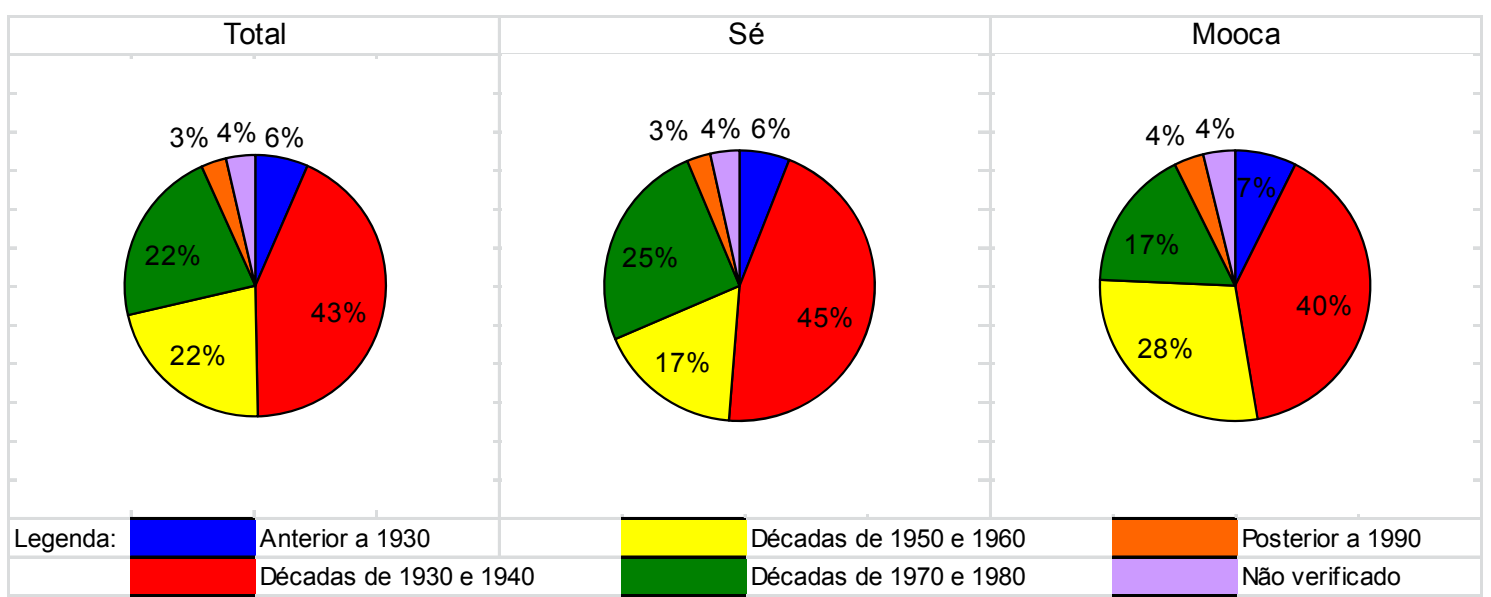

Gráfico 13 - Dados Cadastrais dos Imóveis - Ano de Construção 
Tabela 28 - Dados Cadastrais dos Imóveis - Valor por Metro Quadrado Total de cortiços em funcionamento: 996

\begin{tabular}{|c|c|c|c|c|c|}
\hline \multicolumn{2}{|c|}{ Total } & \multicolumn{2}{|c|}{ Sé } & \multicolumn{2}{|c|}{ Mooca } \\
\hline Imóveis & Famílias & Imóveis & Famílias & Imóveis & \multirow[t]{2}{*}{ Famílias } \\
\hline \multicolumn{2}{|c|}{ Menos que R\$ 400} & & & & \\
\hline 53 & 477 & 26 & 228 & 27 & 249 \\
\hline $5 \%$ & $5 \%$ & $4 \%$ & $4 \%$ & $7 \%$ & $7 \%$ \\
\hline \multicolumn{2}{|c|}{ De $R \$ 400$ a $R \$ 800$} & & & & \\
\hline 433 & 3.669 & 189 & 1.558 & 244 & 2.111 \\
\hline $43 \%$ & $39 \%$ & $31 \%$ & $27 \%$ & $62 \%$ & $58 \%$ \\
\hline \multicolumn{2}{|c|}{ De $R \$ 800$ a $R \$ 1.200$} & & & & \\
\hline 297 & 2.887 & 219 & 2.155 & 78 & 732 \\
\hline $30 \%$ & $31 \%$ & $36 \%$ & $38 \%$ & $20 \%$ & $20 \%$ \\
\hline \multicolumn{2}{|c|}{ De $R \$ 1.200$ a $R \$ 1.600$} & & & & \\
\hline 113 & 1.302 & 91 & 1.120 & 22 & 182 \\
\hline $11 \%$ & $14 \%$ & $15 \%$ & $20 \%$ & $6 \%$ & $5 \%$ \\
\hline \multicolumn{6}{|c|}{ Mais de $R \$ 1.600$} \\
\hline 67 & 766 & 59 & 579 & 8 & 187 \\
\hline $7 \%$ & $8 \%$ & $10 \%$ & $10 \%$ & $2 \%$ & $5 \%$ \\
\hline \multicolumn{6}{|l|}{ Não verificado } \\
\hline 33 & 275 & 17 & 92 & 16 & 183 \\
\hline $3 \%$ & $3 \%$ & $3 \%$ & $2 \%$ & $4 \%$ & $5 \%$ \\
\hline
\end{tabular}

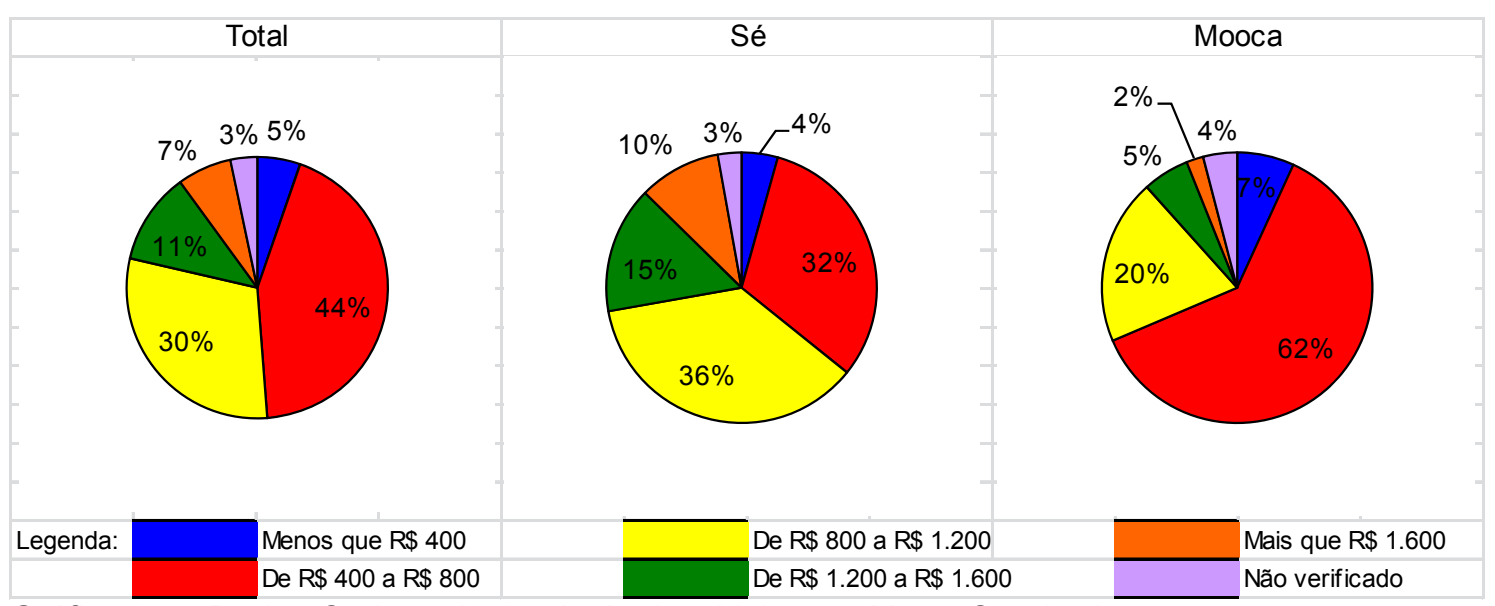

Gráfico 14 - Dados Cadastrais dos Imóveis - Valor por Metro Quadrado 


\subsection{Aspectos do trabalho social}

Embora o Programa de Cortiços, em seu início, enfatize a fiscalização dos imóveis, o primeiro contato com proprietários e responsáveis, logo após as intimações, tem um teor educativo e informativo a respeito dos direitos e deveres de locadores, sublocadores e sublocatários.

As famílias moradoras dos cortiços passam a ter um envolvimento maior com o trabalho social a partir das diversas etapas do Programa. Todas as visitas realizadas pelas equipes de arquitetos e engenheiros são acompanhadas de assistentes sociais. A primeira visita se dá no levantamento do imóvel. Esse contato com funcionários da prefeitura conduz as famílias às diversas redes públicas de atendimento, tais como atendimento de saúde, de educação, cursos de capacitação profissional envolvendo as famílias em mecanismos públicos de geração de renda disponíveis em outras secretarias municipais.

A segunda visita realizada pela equipe é marcada pela entrega do instrumental "Recomendação de Obra". Ao entrar no imóvel pela segunda vez, a equipe estabelece com as famílias uma relação de caráter consultivo e de orientação em relação às mais diversas situações vivenciadas por elas. A terceira visita se dá quando o imóvel entra em obras. A partir desse momento, as visitas da equipe de assistentes sociais se desvinculam da equipe de arquitetos e engenheiros, passando a desenvolver uma programação de reuniões que abordam temas como regimento interno do imóvel, questões de segurança, higiene, discussão da Lei Moura e da Lei do Inquilinato e de informações referentes às famílias que optarão pelos atendimentos habitacionais da CDHU.

Durante o período de reuniões aplica-se um novo instrumental com informações socioeconômicas mais completas do que aquelas obtidas no arrolamento inicial. O desenvolvimento do trabalho com as famílias toma mais tempo do que o trabalho desenvolvido pelos arquitetos e engenheiros. Muitas vezes, um atendimento familiar, dependendo da gravidade do assunto, pode se tornar privativo, e invariavelmente as soluções e encaminhamentos se dão caso a caso. 
Segundo o Relatório, no período de vistorias foram arroladas aproximadamente 9 mil famílias em 865 cortiços (Tabela 29). Utilizando a média encontrada de 10,84 famílias por cortiços (Tabela 15), temos uma projeção de 10.796 famílias morando nos 996 cortiços. Multiplicando pela média de 1,68 pessoa por família (Tabela 15), podemos estimar uma população de 18.137 habitantes morando em cortiços na área central da cidade. Podemos recordar o contingente populacional em cortiços indicado pela pesquisa Seade de 2002 (mapeamento CDHU) em 38 mil habitantes.

Como o Programa se desenvolve em parceria com a CDHU, uma parte dos atendimentos é realizada através de programas habitacionais do Programa de Ação em Cortiços (PAC) da companhia, que são o Programa de Cartas de Crédito e os edifícios residenciais. No Relatório temos aproximadamente 2.500 famílias encaminhadas para atendimentos desses programas habitacionais desde 0 ano 2005 (Tabela 29).

Tabela 29 - Análise do Trabalho Social - Geral

Total de cortiços em funcionamento: 996

\begin{tabular}{|c|c|c|c|c|c|}
\hline \multicolumn{2}{|c|}{ Total } & \multicolumn{2}{|c|}{ Sé } & \multicolumn{2}{|c|}{ Mooca } \\
\hline Imóveis & Famílias & Imóveis & Famílias & Imóveis & Famílias \\
\hline \multicolumn{6}{|c|}{ Arrolamento de famílias } \\
\hline 865 & 9.376 & 505 & 5.732 & 360 & 3.644 \\
\hline $87 \%$ & $100 \%$ & $84 \%$ & $100 \%$ & $91 \%$ & $100 \%$ \\
\hline \multicolumn{6}{|c|}{ Estimativa do total de famílias* } \\
\hline 996 & 10.796 & 601 & 6.822 & 395 & 3.998 \\
\hline $100 \%$ & $115 \%$ & $100 \%$ & $119 \%$ & $100 \%$ & $110 \%$ \\
\hline \multicolumn{6}{|c|}{ Cadastro social simplificado } \\
\hline 0 & 0 & 0 & 0 & 0 & 0 \\
\hline $0 \%$ & $0 \%$ & $0 \%$ & $0 \%$ & $0 \%$ & $0 \%$ \\
\hline \multicolumn{6}{|c|}{ Encaminhamento para CDHU } \\
\hline 244 & 2.505 & 101 & 1.092 & 143 & 1.413 \\
\hline $24 \%$ & $27 \%$ & $17 \%$ & $19 \%$ & $36 \%$ & $39 \%$ \\
\hline
\end{tabular}




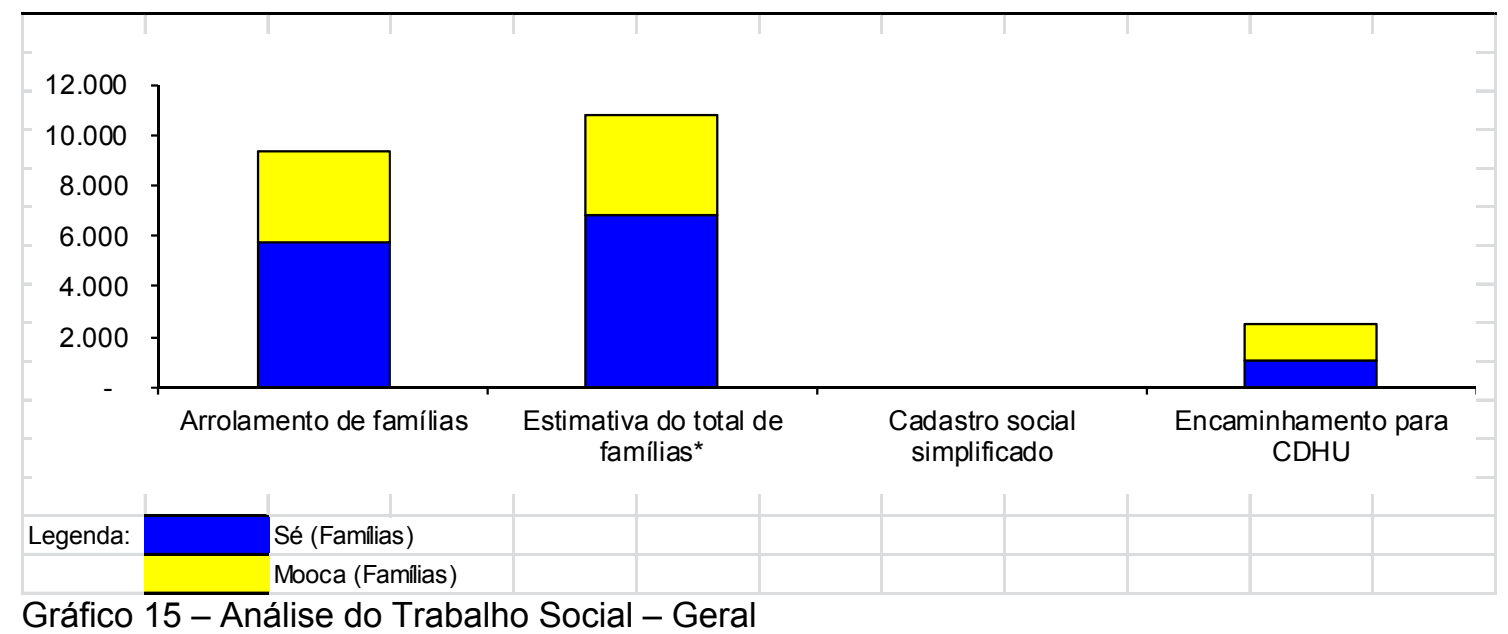

O gráfico a seguir monitora a quantidade de reuniões iniciais, específicas, de reforço e de atividades pedagógicas realizadas pela equipe de assistentes sociais do Programa, conforme as atividades definidas no Quadro Lógico do Programa.

Tabela 30 - Análise do Trabalho Social - Acompanhamento

\begin{tabular}{|c|c|c|c|c|c|}
\hline \multicolumn{2}{|c|}{ Total } & \multicolumn{2}{|c|}{ Sé } & \multicolumn{2}{|c|}{ Mooca } \\
\hline \multirow{2}{*}{$\begin{array}{c}\text { Imóveis } \\
\text { Imóveis visitados }\end{array}$} & Famílias & Imóveis & Famílias & Imóveis & \multirow[t]{2}{*}{ Famílias } \\
\hline & & & & & \\
\hline 43 & 489 & 1 & - & 42 & 489 \\
\hline $4 \%$ & $5 \%$ & & & $11 \%$ & $13 \%$ \\
\hline \multicolumn{6}{|l|}{ Reuniões iniciais } \\
\hline 42 & 497 & 1 & - & 41 & 497 \\
\hline $4 \%$ & $5 \%$ & & & $10 \%$ & $14 \%$ \\
\hline \multicolumn{2}{|c|}{ Reuniões específicas } & & & \multirow{3}{*}{1} & \multirow[b]{2}{*}{29} \\
\hline 1 & 29 & \multirow[t]{2}{*}{ - } & - & & \\
\hline & $0 \%$ & & & & $1 \%$ \\
\hline \multicolumn{2}{|c|}{ Reuniões de reforço } & & & & \multirow[b]{2}{*}{29} \\
\hline 1 & \multirow[t]{2}{*}{29} & - & - & 1 & \\
\hline & & & & & $1 \%$ \\
\hline Atividades pedag & & & & & \\
\hline 1 & 29 & - & - & 1 & 29 \\
\hline & & & & & $1 \%$ \\
\hline Atividades de par & - Nós do Cent & & & & \\
\hline 1 & 29 & - & - & 1 & 29 \\
\hline & & & & & $1 \%$ \\
\hline Atividades de par & - Eletropaulo & & & & \\
\hline 1 & 29 & - & - & 1 & 29 \\
\hline Atividades de par & - Sabesp & & & & \\
\hline 1 & 29 & - & - & 1 & 29 \\
\hline & & & & & \\
\hline
\end{tabular}




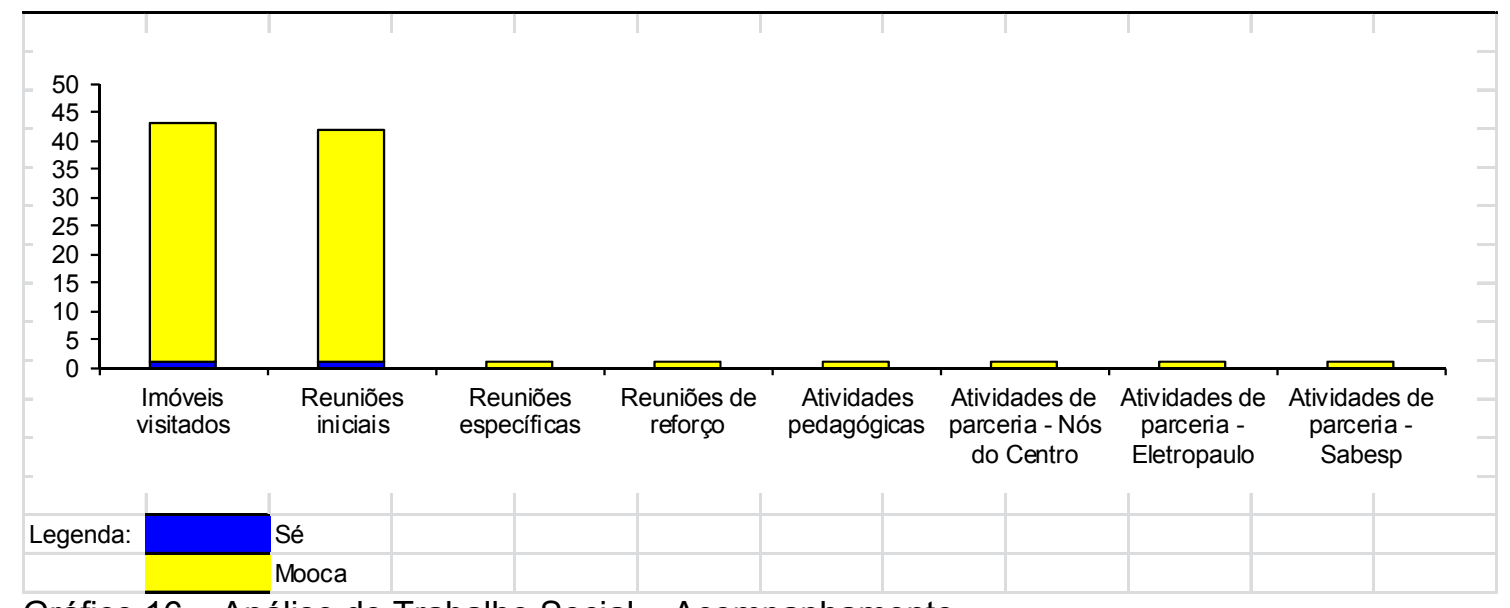

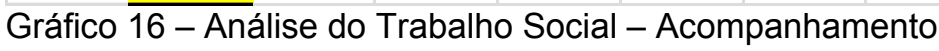

O trabalho social do Programa de Cortiços foi definido no Quadro Lógico. Entretanto, algumas atividades foram implementadas somente após dois anos do início das primeiras intimações. O monitoramento das atividades consta no gráfico abaixo. As adequações de cortiços, ainda que em andamento, contam como serviços prestados pelo Programa, alcançando um total de aproximadamente 7 mil famílias beneficiadas pelas adequações (Tabela 31).

O gráfico contempla ainda a quantidade de famílias encaminhadas para atendimentos habitacionais previstos no Programa de Ação em Cortiços (PAC/CDHU). Segundo o Relatório, 520 famílias foram atendidas em unidades habitacionais e aproximadamente 1.000 famílias foram atendidas pelo Programa de Carta de Crédito. 
Tabela 31 - Análise do Trabalho Social - Atendimentos e Benefícios Realizados Total de cortiços vistoriados: 1166

\begin{tabular}{|c|c|c|c|c|c|}
\hline \multicolumn{2}{|c|}{ Total } & \multicolumn{2}{|c|}{ Sé } & \multicolumn{2}{|c|}{ Mooca } \\
\hline Imóveis & Famílias & Imóveis & Famílias & Imóveis & Famílias \\
\hline \multicolumn{6}{|c|}{ Atendidos com unidades habitacionais da CDHU } \\
\hline 228 & 520 & 91 & 235 & 137 & 285 \\
\hline $20 \%$ & $5 \%$ & $13 \%$ & $3 \%$ & $30 \%$ & $7 \%$ \\
\hline \multicolumn{6}{|c|}{ Atendidos com carta de crédito da CDHU } \\
\hline 184 & 972 & 99 & 612 & 85 & 360 \\
\hline $16 \%$ & $9 \%$ & $14 \%$ & $9 \%$ & $18 \%$ & $8 \%$ \\
\hline \multicolumn{6}{|c|}{ Atendidos com ajuda de custo da CDHU } \\
\hline 79 & 439 & 57 & 281 & 22 & 158 \\
\hline $7 \%$ & $4 \%$ & $8 \%$ & $4 \%$ & $5 \%$ & $4 \%$ \\
\hline \multicolumn{2}{|c|}{ Atendidos com verba da PMSP } & & \multirow[b]{2}{*}{26} & & \multirow[b]{2}{*}{13} \\
\hline 39 & 39 & 26 & & 13 & \\
\hline $3 \%$ & $0 \%$ & $4 \%$ & $0 \%$ & $3 \%$ & $0 \%$ \\
\hline Cortiços certif & & & & & \\
\hline 7 & 36 & 2 & 2 & 5 & 34 \\
\hline $1 \%$ & $0 \%$ & $0 \%$ & $0 \%$ & $1 \%$ & $1 \%$ \\
\hline Cortiços em o & adequação & & & & \\
\hline 748 & 7.315 & 441 & 4390 & 307 & 2925 \\
\hline $64 \%$ & $67 \%$ & $62 \%$ & $65 \%$ & $67 \%$ & $69 \%$ \\
\hline
\end{tabular}

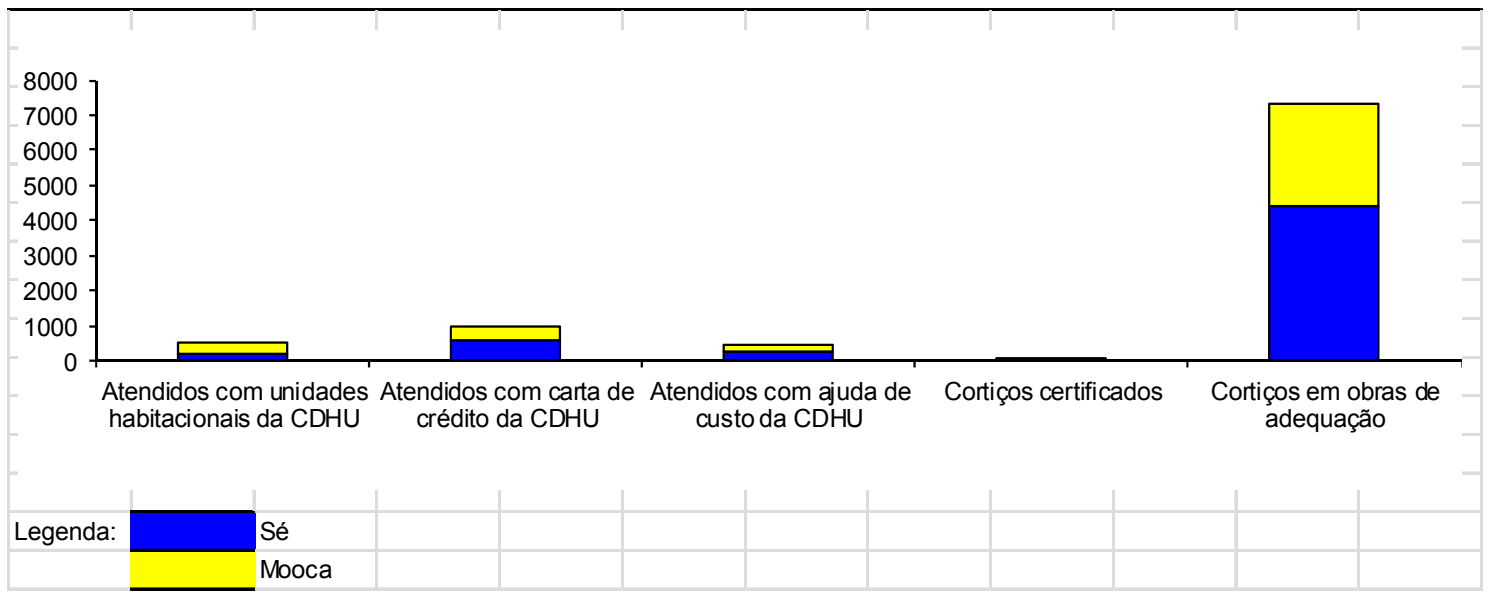

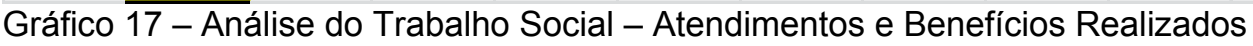




\subsection{Aspectos da degradação em cortiços}

Do universo de aproximadamente 1.000 cortiços em funcionamento, $90 \%$ são casas ou sobrados (Tabela 22) com área construída em torno de $300 \mathrm{~m}^{2} \mathrm{e}$ apresentam uma média de 10,84 (Tabela 15) famílias por cortiço. Vemos que $72 \%$ deles foram construídos antes de 1960, portanto com idade acima de 50 anos e com uma degradação causada pela falta de manutenção ao longo de quase meio século de vida. Sendo assim, por se tratar de obras de pequeno porte em imóveis pequenos os serviços não são considerados de execução complexa, assemelhandose muitas vezes a pequenas reformas realizadas em residências comuns.

Após o levantamento concluiu-se que 870 imóveis apresentam uma condição física não muito aquém das exigências da Lei Moura. Um pequeno volume de serviços de obra poderia enquadrar os imóveis nas exigências da lei. São obras simples, como recuperação parcial do telhado, recolocação de rufo e calha, colocação de fios e cabos elétricos aparentes em canaletas apropriadas, correção de infiltrações, entre outras.

Outros 207 imóveis apresentaram necessidade de uma intervenção maior. São os mesmos serviços de obra, porém com um volume maior de serviços, ou seja, recuperação integral do telhado, rufo e calhas, substituição total do forro, reforma total de banheiros e áreas molhadas.

Além dos imóveis que permitem uma condição de recuperação através de obras, opera-se uma situação de interdição do imóvel, não cabendo informações de obra para esses casos. A quantidade de imóveis encortiçados que apresentam sérios riscos à saúde e riscos estruturais é substancialmente menor. São 91 imóveis que necessitam imediata interdição.

O aspecto mais preocupante da degradação nos cortiços é a salubridade do ambiente. As alíneas "b", "c", "d" e "e" do artigo $3^{\circ}$ da Lei n 10.928, de 1991, dispõem, respectivamente, sobre a iluminação, ventilação, dimensionamento dos cômodos e densidade nos cortiços. 
As alíneas "b" e "c", iluminação e ventilação, não são obedecidas em $65 \%$ (tabelas 32 e 33) dos imóveis. Nenhum desses itens foi flexibilizado pela lei que regulamenta cortiços e segue o disposto no Código de Obras e Edificações do Município de São Paulo, que exige 1/7 da área de piso para a iluminação e a metade disso para a ventilação nos dormitórios.

O gráfico importante foi construído para possibilitar o acompanhamento da evolução das reformas através do quadro "Visita mais recente" (Tabela 55). Nesse gráfico, na última visita realizada no imóvel pela equipe de gestão do Programa, toma-se nota dos serviços de obra já realizados. Por exemplo, se o instrumental Vistoria Prévia indica uma inadequação na ventilação ocasionada pela degradação ou mau dimensionamento de uma janela, e a troca da janela foi realizada, isso significa que o quesito ventilação já está em conformidade com a Lei Moura.

A adequação observada na Vistoria mais Recente é anotada e inserida no banco de dados do Relatório de Progresso. Dessa forma, o item ventilação passa a ter um monitoramento isolado.

O mesmo ocorre com os demais itens que compõem o levantamento, possibilitando uma análise isolada por item na melhoria dos imóveis.

Na prática, a leitura desses gráficos - Visita mais Recente - poderá indicar que, em uma situação hipotética, não obstante os 1.000 cortiços não tenham finalizado suas obras, os quesitos ventilação e iluminação se encontram adequados em $100 \%$ dos imóveis.

Uma situação real semelhante a essa poderia reconduzir os trabalhos da equipe de gestão para uma etapa de replanejamento do Programa. 
Tabela 32 - Caracterização dos Imóveis - Salubridade - Ventilação

Total de cortiços em funcionamento: 996

\begin{tabular}{|c|c|c|c|c|c|}
\hline \multicolumn{2}{|c|}{ Total } & \multicolumn{2}{|c|}{ Sé } & \multicolumn{2}{|c|}{ Mooca } \\
\hline \multirow{2}{*}{$\frac{\text { Imóveis }}{\text { Vistoria prévia }}$} & Famílias & Imóveis & Famílias & Imóveis & Famílias \\
\hline & & & & & \\
\hline \multicolumn{6}{|l|}{ Conforme } \\
\hline 332 & 2.697 & 202 & 1.717 & 130 & 980 \\
\hline $33 \%$ & $29 \%$ & $34 \%$ & $30 \%$ & $33 \%$ & $27 \%$ \\
\hline \multicolumn{6}{|l|}{ Não conforme } \\
\hline 645 & 6.594 & 389 & 3.937 & 256 & 2.657 \\
\hline $65 \%$ & $70 \%$ & $65 \%$ & $69 \%$ & $65 \%$ & $73 \%$ \\
\hline \multicolumn{6}{|l|}{ Não vistoriado } \\
\hline 19 & 85 & 10 & 78 & 9 & 7 \\
\hline $2 \%$ & $1 \%$ & $2 \%$ & $1 \%$ & $2 \%$ & $0 \%$ \\
\hline & & & & & \\
\hline \multicolumn{6}{|c|}{ Visita mais recente } \\
\hline \multicolumn{6}{|l|}{ Conforme } \\
\hline 332 & 2.693 & 201 & 1.717 & 131 & 976 \\
\hline $33 \%$ & $29 \%$ & $33 \%$ & $30 \%$ & $33 \%$ & $27 \%$ \\
\hline \multicolumn{6}{|l|}{ Não conforme } \\
\hline 643 & 6.585 & 388 & 3.924 & 255 & 2.661 \\
\hline $65 \%$ & $70 \%$ & $65 \%$ & $68 \%$ & $65 \%$ & $73 \%$ \\
\hline \multicolumn{6}{|l|}{ Não vistoriado } \\
\hline 21 & 98 & 12 & 91 & 9 & 7 \\
\hline $2 \%$ & $1 \%$ & $2 \%$ & $2 \%$ & $2 \%$ & $0 \%$ \\
\hline
\end{tabular}

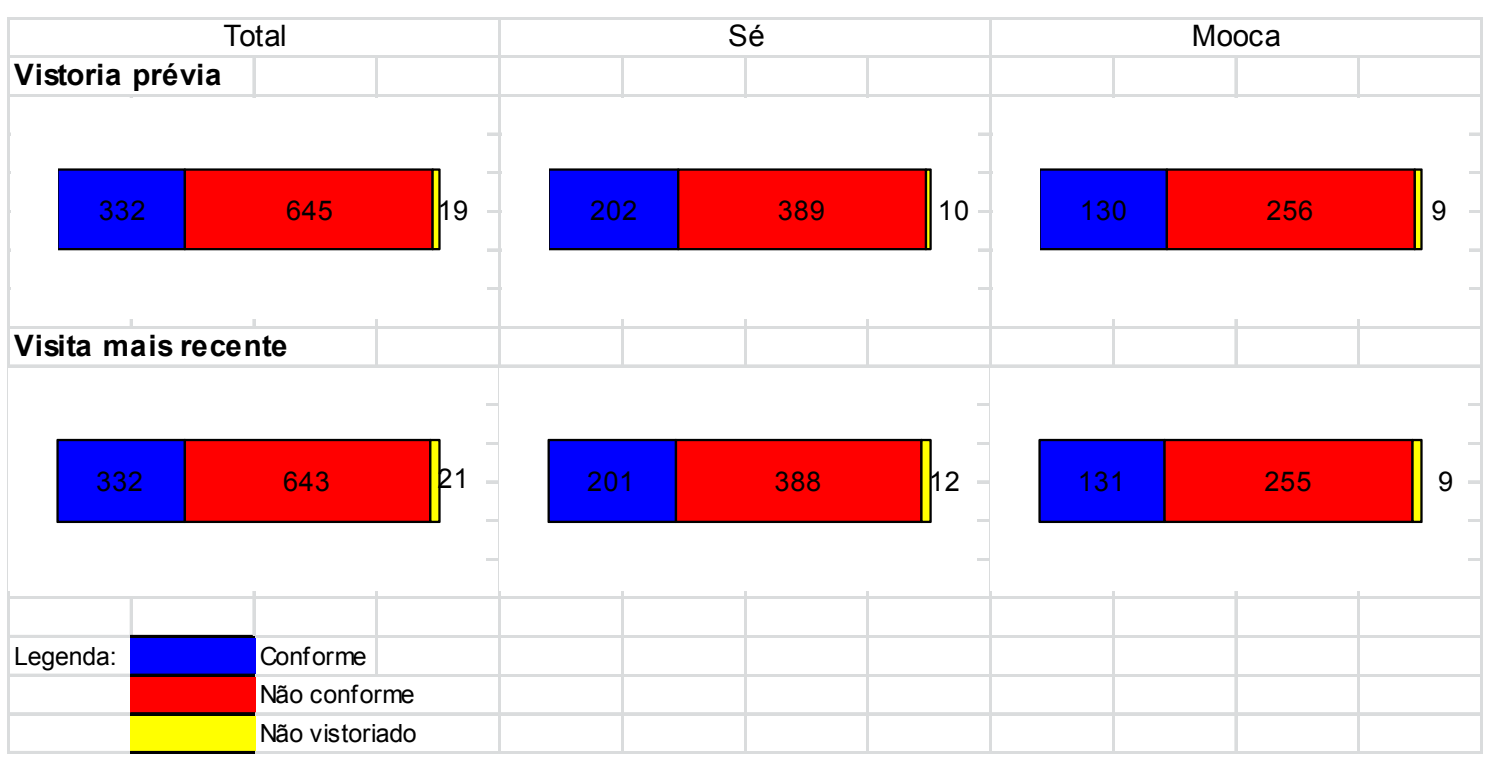

Gráfico $\overline{18-\text { Salubridade - Ventilação }}$ 
Tabela 33 - Caracterização dos Imóveis - Salubridade - lluminação

Total de cortiços em funcionamento: 996

\begin{tabular}{|c|c|c|c|c|c|}
\hline \multicolumn{2}{|c|}{ Total } & \multicolumn{2}{|c|}{ Sé } & \multicolumn{2}{|c|}{ Mooca } \\
\hline Imóveis & Famílias & Imóveis & Famílias & Imóveis & \multirow[t]{2}{*}{ Famílias } \\
\hline \multicolumn{5}{|l|}{ Vistoria prévia } & \\
\hline \multicolumn{6}{|l|}{ Conforme } \\
\hline 329 & 2.585 & 208 & 1.716 & 121 & 869 \\
\hline $33 \%$ & $28 \%$ & $35 \%$ & $30 \%$ & $31 \%$ & $24 \%$ \\
\hline \multicolumn{6}{|l|}{ Não conforme } \\
\hline 648 & 6.706 & 383 & 3.938 & 265 & 2.768 \\
\hline $65 \%$ & $72 \%$ & $64 \%$ & $69 \%$ & $67 \%$ & $76 \%$ \\
\hline \multicolumn{6}{|l|}{ Não vistoriado } \\
\hline 19 & 85 & 10 & 78 & 9 & 7 \\
\hline $2 \%$ & $1 \%$ & $2 \%$ & $1 \%$ & $2 \%$ & $0 \%$ \\
\hline & & & & & \\
\hline \multicolumn{6}{|c|}{ Visita mais recente } \\
\hline \multicolumn{6}{|c|}{ Conforme } \\
\hline 330 & 2.597 & 207 & 1.716 & 123 & 881 \\
\hline $33 \%$ & $28 \%$ & $34 \%$ & $30 \%$ & $31 \%$ & $24 \%$ \\
\hline \multicolumn{6}{|l|}{ Não conforme } \\
\hline 645 & 6.681 & 382 & 3.925 & 263 & 2.756 \\
\hline $65 \%$ & $71 \%$ & $64 \%$ & $68 \%$ & $67 \%$ & $76 \%$ \\
\hline \multicolumn{6}{|l|}{ Não vistoriado } \\
\hline 21 & 98 & 12 & 91 & 9 & 7 \\
\hline $2 \%$ & $1 \%$ & $2 \%$ & $2 \%$ & $2 \%$ & $0 \%$ \\
\hline
\end{tabular}

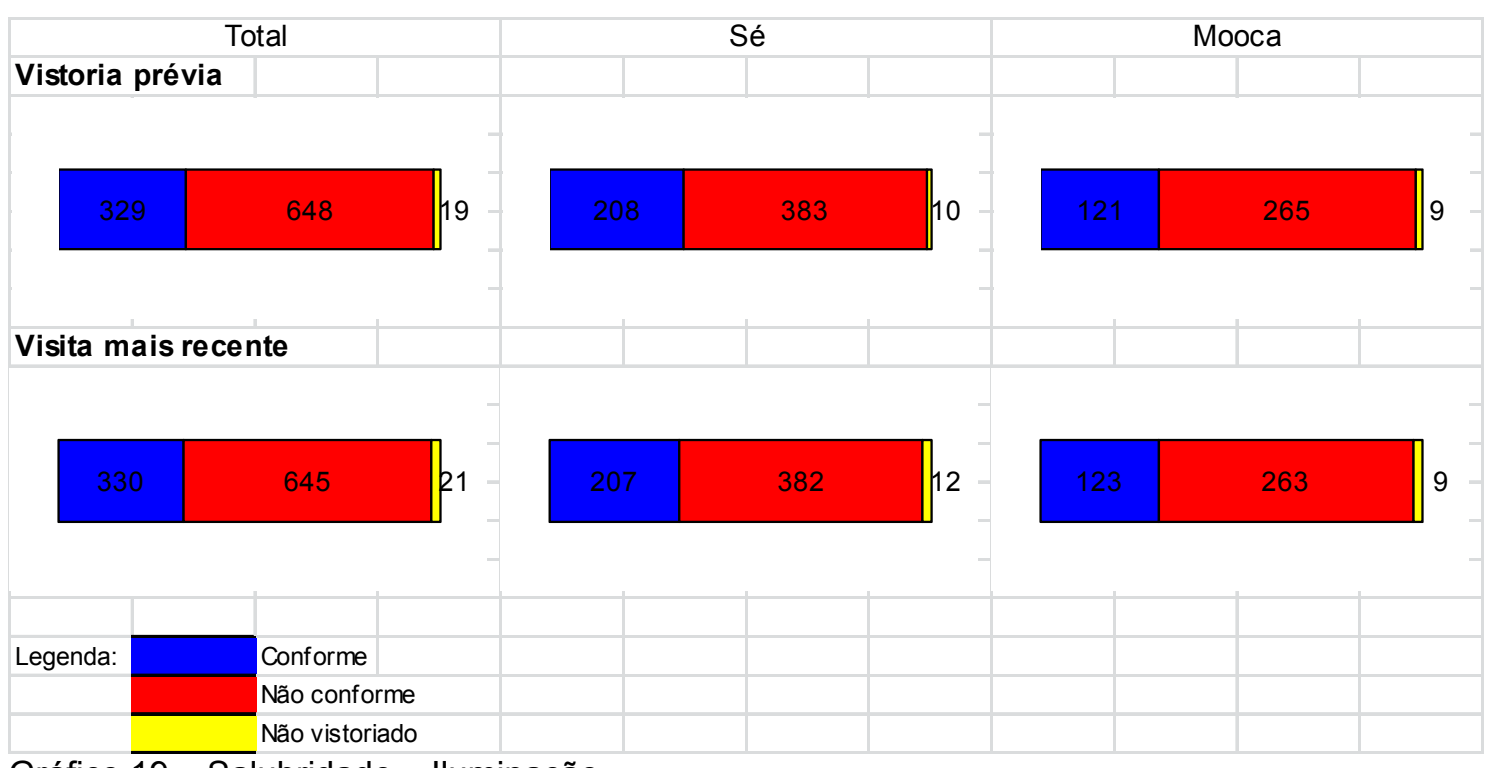

Gráfico $\overline{19-\text { Salubridade - Iluminação }}$

Quanto ao dimensionamento do cômodo nos cortiços, observa-se que a área construída mínima por pessoa é $96 \%$ superior ao exigido pela Lei Moura. A alínea "d" estabelece um mínimo de $5 \mathrm{~m}^{2}$ para cada cômodo de cortiço e apresenta $78 \%$ de conformidade (Tabela 34). A média de área encontrada nos cômodos é de $9,8 \mathrm{~m}^{2}$. 
Tabela 34 - Caracterização dos Imóveis - Salubridade - Área Mínima

Total de cortiços em funcionamento: 996

\begin{tabular}{|c|c|c|c|c|c|}
\hline \multicolumn{2}{|c|}{ Total } & \multicolumn{2}{|c|}{ Sé } & \multicolumn{2}{|c|}{ Mooca } \\
\hline \multirow{2}{*}{$\begin{array}{c}\text { Imóveis } \\
\text { Vistoria prévia }\end{array}$} & Famílias & Imóveis & Famílias & Imóveis & Famílias \\
\hline & & & & & \\
\hline \multicolumn{6}{|l|}{ Conforme } \\
\hline 772 & 6.904 & 484 & 4.363 & 288 & 2.541 \\
\hline $78 \%$ & $74 \%$ & $81 \%$ & $76 \%$ & $73 \%$ & $70 \%$ \\
\hline \multicolumn{6}{|l|}{ Não conforme } \\
\hline 205 & 2.387 & 107 & 1.291 & 98 & 1.096 \\
\hline $21 \%$ & $25 \%$ & $18 \%$ & $23 \%$ & $25 \%$ & $30 \%$ \\
\hline \multicolumn{6}{|l|}{ Não vistoriado } \\
\hline 19 & 85 & 10 & 78 & 9 & 7 \\
\hline $2 \%$ & $1 \%$ & $2 \%$ & $1 \%$ & $2 \%$ & $0 \%$ \\
\hline & & & & & \\
\hline \multicolumn{6}{|c|}{ Visita mais recente } \\
\hline \multicolumn{6}{|l|}{ Conforme } \\
\hline 777 & 6.991 & 484 & 4.363 & 293 & 2.628 \\
\hline $78 \%$ & $75 \%$ & $81 \%$ & $76 \%$ & $74 \%$ & $72 \%$ \\
\hline \multicolumn{6}{|l|}{ Não conforme } \\
\hline 198 & 2.287 & 105 & 1.278 & 93 & 1.009 \\
\hline $20 \%$ & $24 \%$ & $17 \%$ & $22 \%$ & $24 \%$ & $28 \%$ \\
\hline \multicolumn{6}{|l|}{ Não vistoriado } \\
\hline 21 & 98 & 12 & 91 & 9 & 7 \\
\hline $2 \%$ & $1 \%$ & $2 \%$ & $2 \%$ & $2 \%$ & $0 \%$ \\
\hline
\end{tabular}

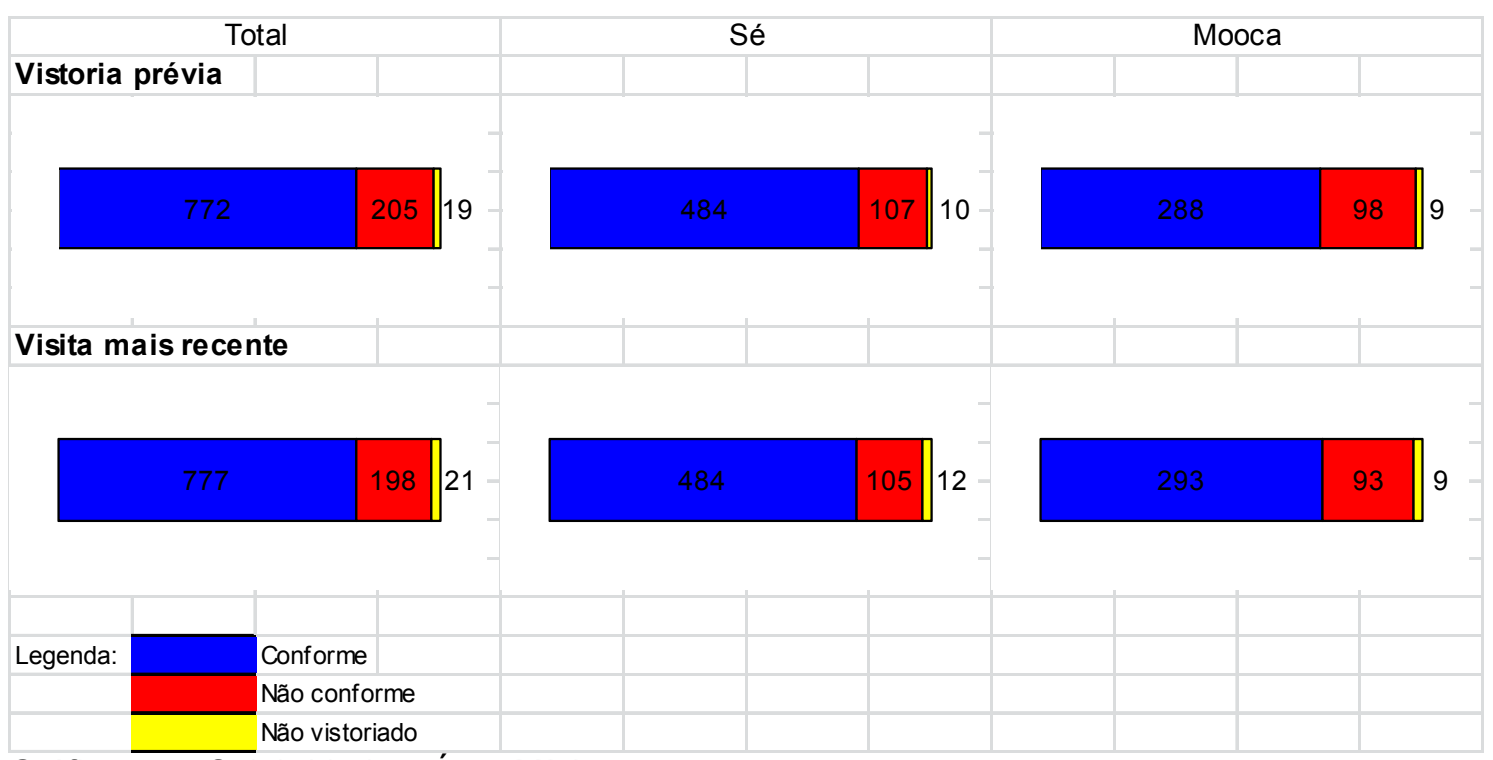

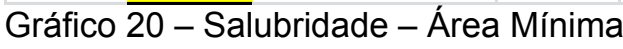

A alínea "e", que define uma densidade de duas pessoas para cada $8 \mathrm{~m}^{2} \mathrm{em}$ relação à área construída total do imóvel, apresenta 86\% (Tabela 35) de conformidade. A média encontrada foi de $12 \mathrm{~m}^{2}$ por pessoa, somente um pouco abaixo do exigido pelo Código de Obras, que exige $15 \mathrm{~m}^{2}$ por pessoa para usos residenciais. 
Tabela 35 - Caracterização dos Imóveis - Salubridade - Adensamento Máximo Total de cortiços em funcionamento: 996

\begin{tabular}{|c|c|c|c|c|c|}
\hline \multicolumn{2}{|c|}{ Total } & \multicolumn{2}{|c|}{ Sé } & \multicolumn{2}{|c|}{ Mooca } \\
\hline \multirow{2}{*}{$\frac{\text { Imóveis }}{\text { Vistoria prévia }}$} & Famílias & Imóveis & Famílias & Imóveis & Famílias \\
\hline & & & & & \\
\hline \multicolumn{6}{|l|}{ Conforme } \\
\hline 857 & 7.821 & 497 & 4.496 & 360 & 3.325 \\
\hline $86 \%$ & $83 \%$ & $83 \%$ & $78 \%$ & $91 \%$ & $91 \%$ \\
\hline \multicolumn{6}{|l|}{ Não conforme } \\
\hline 120 & 1.470 & 94 & 1.158 & 26 & 312 \\
\hline $12 \%$ & $16 \%$ & $16 \%$ & $20 \%$ & $7 \%$ & $9 \%$ \\
\hline \multicolumn{6}{|l|}{ Não vistoriado } \\
\hline 19 & 85 & 10 & 78 & 9 & 7 \\
\hline $2 \%$ & $1 \%$ & $2 \%$ & $1 \%$ & $2 \%$ & $0 \%$ \\
\hline & & & & & \\
\hline \multirow{2}{*}{\multicolumn{6}{|c|}{$\begin{array}{l}\text { Visita mais recente } \\
\text { Conforme }\end{array}$}} \\
\hline & & & & & \\
\hline 857 & 7.829 & 496 & 4.496 & 361 & 3.333 \\
\hline $86 \%$ & $84 \%$ & $83 \%$ & $78 \%$ & $91 \%$ & $91 \%$ \\
\hline Não conforme & & & & & \\
\hline 118 & 1.449 & 93 & 1.145 & 25 & 304 \\
\hline $12 \%$ & $15 \%$ & $15 \%$ & $20 \%$ & $6 \%$ & $8 \%$ \\
\hline Não vistoriado & & & & & \\
\hline 21 & 98 & 12 & 91 & 9 & 7 \\
\hline $2 \%$ & $1 \%$ & $2 \%$ & $2 \%$ & $2 \%$ & $0 \%$ \\
\hline
\end{tabular}

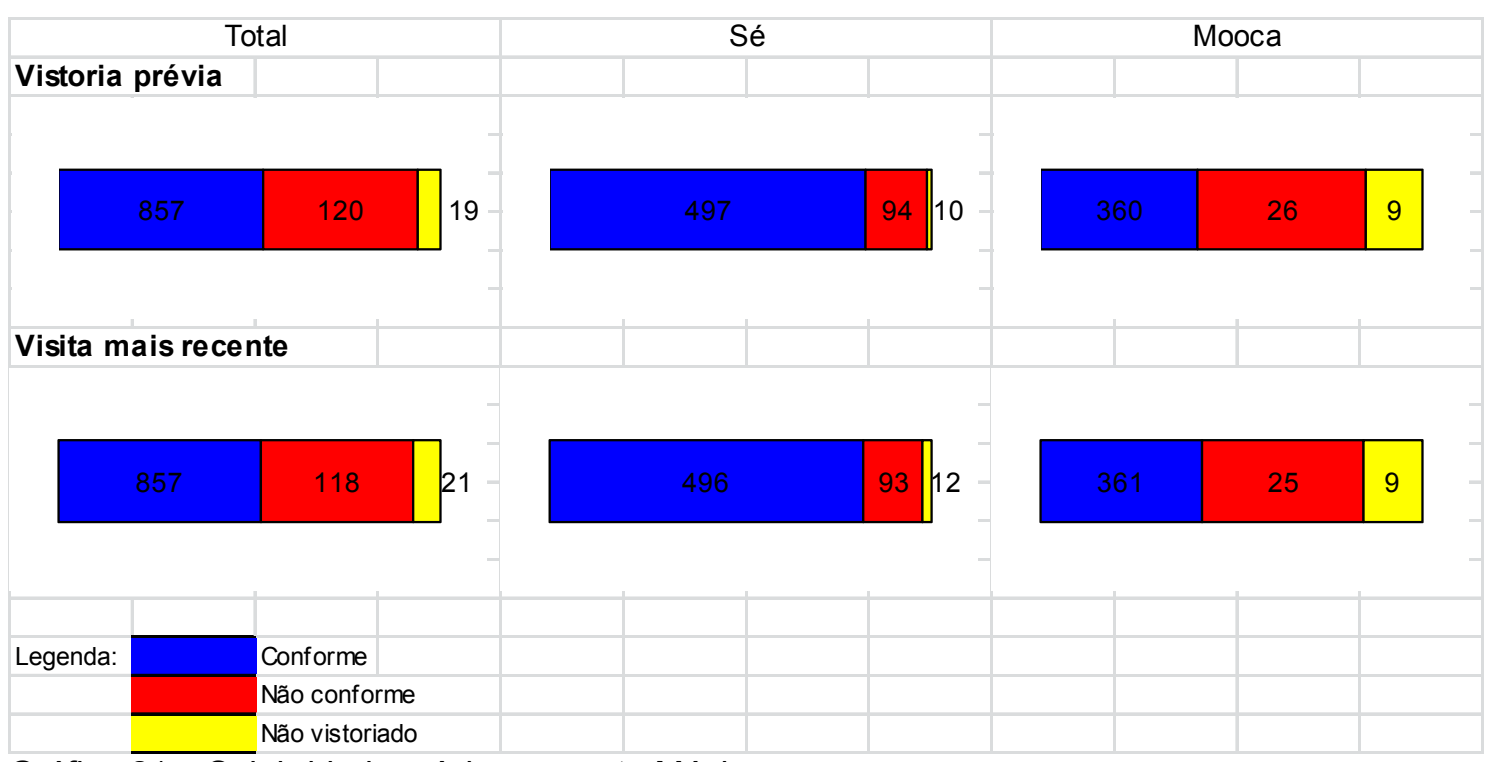

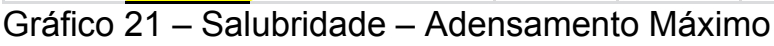

A umidade dos banheiros contribui para as altas porcentagens de umidade $\mathrm{e}$ temperatura elevadas. Grande parte desse problema é resolvida através das reformas dos banheiros, especificamente com a colocação de revestimento nas paredes ou a simples impermeabilização das paredes dos banheiros com produtos 
específicos. Constatou-se que $64 \%$ dos casos (Tabela 36) não estão de conformidade com a lei.

Tabela 36 - Caracterização dos Imóveis - Salubridade - Revestimento dos Sanitários

Total de cortiços em funcionamento: 996

\begin{tabular}{|c|c|c|c|c|c|}
\hline \multicolumn{2}{|c|}{ Total } & \multicolumn{2}{|c|}{ Sé } & \multicolumn{2}{|c|}{ Mooca } \\
\hline \multirow{2}{*}{$\frac{\text { Imóveis }}{\text { Vistoria prévia }}$} & Famílias & Imóveis & Famílias & Imóveis & Famílias \\
\hline & & & & & \\
\hline \multicolumn{6}{|l|}{ Conforme } \\
\hline 343 & 3.293 & 170 & 1.496 & 173 & 1.797 \\
\hline $34 \%$ & $35 \%$ & $28 \%$ & $26 \%$ & $44 \%$ & $49 \%$ \\
\hline \multicolumn{6}{|l|}{ Não conforme } \\
\hline 634 & 5.998 & 421 & 4.158 & 213 & 1.840 \\
\hline $64 \%$ & $64 \%$ & $70 \%$ & $73 \%$ & $54 \%$ & $50 \%$ \\
\hline \multicolumn{6}{|l|}{ Não vistoriado } \\
\hline 19 & 85 & 10 & 78 & 9 & 7 \\
\hline $2 \%$ & $1 \%$ & $2 \%$ & $1 \%$ & $2 \%$ & $0 \%$ \\
\hline & & & & & \\
\hline \multicolumn{6}{|c|}{ Visita mais recente } \\
\hline \multicolumn{6}{|l|}{ Conforme } \\
\hline 346 & 3.342 & 170 & 1.496 & 176 & 1.846 \\
\hline $35 \%$ & $36 \%$ & $28 \%$ & $26 \%$ & $45 \%$ & $51 \%$ \\
\hline \multicolumn{6}{|l|}{ Não conforme } \\
\hline 629 & 5.936 & 419 & 4.145 & 210 & 1.791 \\
\hline $63 \%$ & $63 \%$ & $70 \%$ & $72 \%$ & $53 \%$ & $3 \%$ \\
\hline \multicolumn{6}{|l|}{ Não vistoriado } \\
\hline 21 & 98 & 12 & 91 & 9 & 7 \\
\hline $2 \%$ & $1 \%$ & $2 \%$ & $2 \%$ & $2 \%$ & $0 \%$ \\
\hline
\end{tabular}

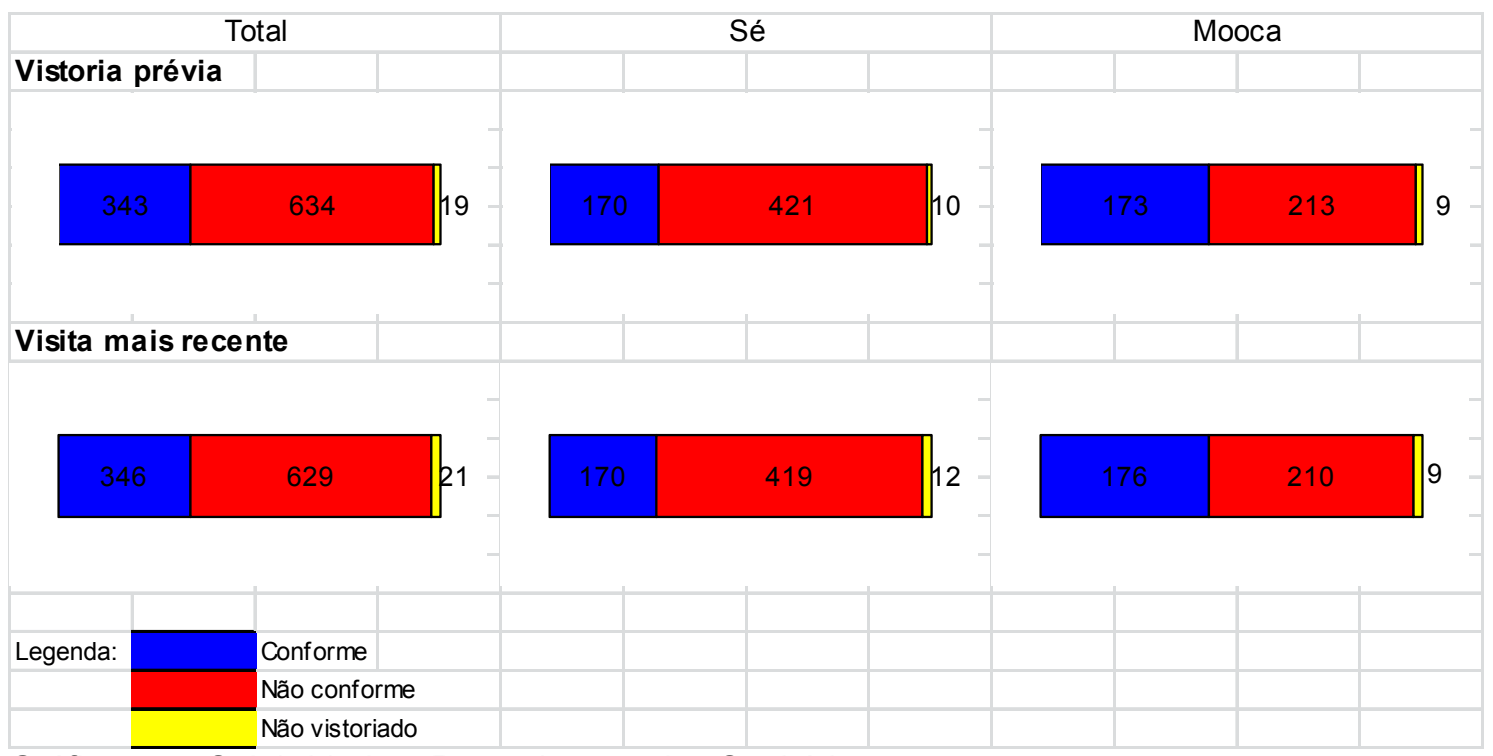

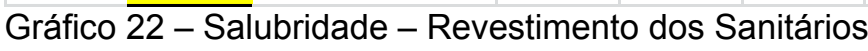

O pé-direito mínimo dos cortiços, segundo a lei, é 2,30 m de altura. Esse item, associado a outros, como a umidade do banheiro e a precariedade da ventilação, contribui para a degradação do ambiente dos cortiços. Vemos que $24 \%$ (tabela 37 ) dos imóveis não atendem ao mínimo exigido. 
Tabela 37 - Caracterização dos Imóveis - Salubridade - Pé-Direito Mínimo

Total de cortiços em funcionamento: 996

\begin{tabular}{|c|c|c|c|c|c|}
\hline \multicolumn{2}{|c|}{ Total } & \multicolumn{2}{|c|}{ Sé } & \multicolumn{2}{|c|}{ Mooca } \\
\hline \multirow{2}{*}{$\frac{\text { Imóveis }}{\text { Vistoria prévia }}$} & Famílias & Imóveis & Famílias & Imóveis & Famílias \\
\hline & & & & & \\
\hline \multicolumn{6}{|l|}{ Conforme } \\
\hline 739 & 6.819 & 465 & 4.252 & 274 & 2.567 \\
\hline $74 \%$ & $73 \%$ & $77 \%$ & $74 \%$ & $69 \%$ & $70 \%$ \\
\hline \multicolumn{6}{|l|}{ Não conforme } \\
\hline 238 & 2.472 & 126 & 1.402 & 112 & 1.070 \\
\hline $24 \%$ & $26 \%$ & $21 \%$ & $24 \%$ & $28 \%$ & $29 \%$ \\
\hline \multicolumn{6}{|l|}{ Não vistoriado } \\
\hline 19 & 85 & 10 & 78 & 9 & 7 \\
\hline $2 \%$ & $1 \%$ & $2 \%$ & $1 \%$ & $2 \%$ & $0 \%$ \\
\hline \multirow{2}{*}{\multicolumn{6}{|c|}{ Visita mais recente }} \\
\hline & & & & & \\
\hline \multicolumn{6}{|l|}{ Conforme } \\
\hline 742 & 6.887 & 464 & 4.252 & 278 & 2.635 \\
\hline $74 \%$ & $73 \%$ & $77 \%$ & $74 \%$ & $70 \%$ & $72 \%$ \\
\hline \multicolumn{6}{|l|}{ Não conforme } \\
\hline 233 & 2.391 & 125 & 1.389 & 108 & 1.002 \\
\hline $23 \%$ & $26 \%$ & $21 \%$ & $24 \%$ & $27 \%$ & $27 \%$ \\
\hline \multicolumn{6}{|l|}{ Não vistoriado } \\
\hline 21 & 98 & 12 & 91 & 9 & 7 \\
\hline $2 \%$ & $1 \%$ & $2 \%$ & $2 \%$ & $2 \%$ & $0 \%$ \\
\hline
\end{tabular}

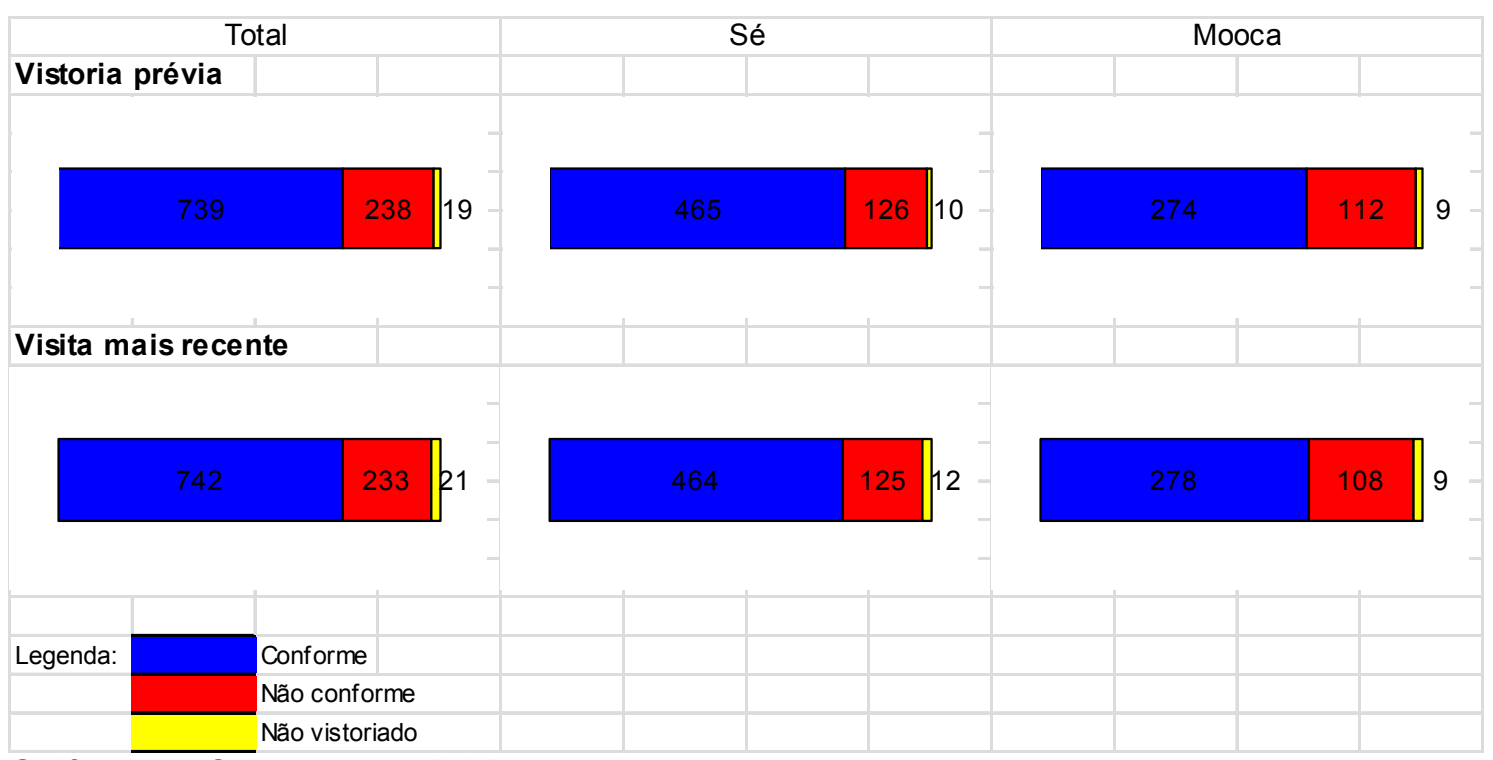

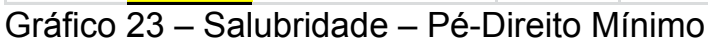

Os espaços de circulação nos imóveis podem ser considerados um fator de agravamento de risco nos cortiços. Em caso de incêndio, a circulação precária dificulta a rota de fuga. Além disso, contribui também para a insalubridade por consequência da precariedade da ventilação. 
Tabela 38 - Caracterização dos Imóveis - Salubridade - Circulação

Total de cortiços em funcionamento: 996

\begin{tabular}{|c|c|c|c|c|c|}
\hline \multicolumn{2}{|c|}{ Total } & \multicolumn{2}{|c|}{ Sé } & \multicolumn{2}{|c|}{ Mooca } \\
\hline \multirow{2}{*}{$\frac{\text { Imóveis }}{\text { Vistoria prévia }}$} & Famílias & Imóveis & \multirow[t]{2}{*}{ Famílias } & Imóveis & \multirow[t]{2}{*}{ Famílias } \\
\hline & & & & & \\
\hline \multicolumn{6}{|l|}{ Conforme } \\
\hline 763 & 6.965 & 451 & 4.212 & 312 & 2.753 \\
\hline $77 \%$ & $74 \%$ & $75 \%$ & $73 \%$ & $79 \%$ & $76 \%$ \\
\hline \multicolumn{6}{|l|}{ Não conforme } \\
\hline 214 & 2.326 & 140 & 1.442 & 74 & 884 \\
\hline $21 \%$ & $25 \%$ & $23 \%$ & $25 \%$ & $19 \%$ & $24 \%$ \\
\hline \multicolumn{6}{|l|}{ Não vistoriado } \\
\hline 19 & 85 & 10 & 78 & 9 & 7 \\
\hline $2 \%$ & $1 \%$ & $2 \%$ & $1 \%$ & $2 \%$ & $0 \%$ \\
\hline & & & & & \\
\hline \multicolumn{6}{|c|}{ Visita mais recente } \\
\hline \multicolumn{6}{|l|}{ Conforme } \\
\hline 763 & 6.970 & 450 & 4.212 & 313 & 2.758 \\
\hline $77 \%$ & $74 \%$ & $75 \%$ & $73 \%$ & $79 \%$ & $76 \%$ \\
\hline \multicolumn{6}{|l|}{ Não conforme } \\
\hline 212 & 2.308 & 139 & 1.429 & 73 & 879 \\
\hline $21 \%$ & $25 \%$ & $23 \%$ & $25 \%$ & $18 \%$ & $24 \%$ \\
\hline \multicolumn{6}{|l|}{ Não vistoriado } \\
\hline 21 & 98 & 12 & 91 & 9 & 7 \\
\hline $2 \%$ & $1 \%$ & $2 \%$ & $2 \%$ & $2 \%$ & $0 \%$ \\
\hline
\end{tabular}

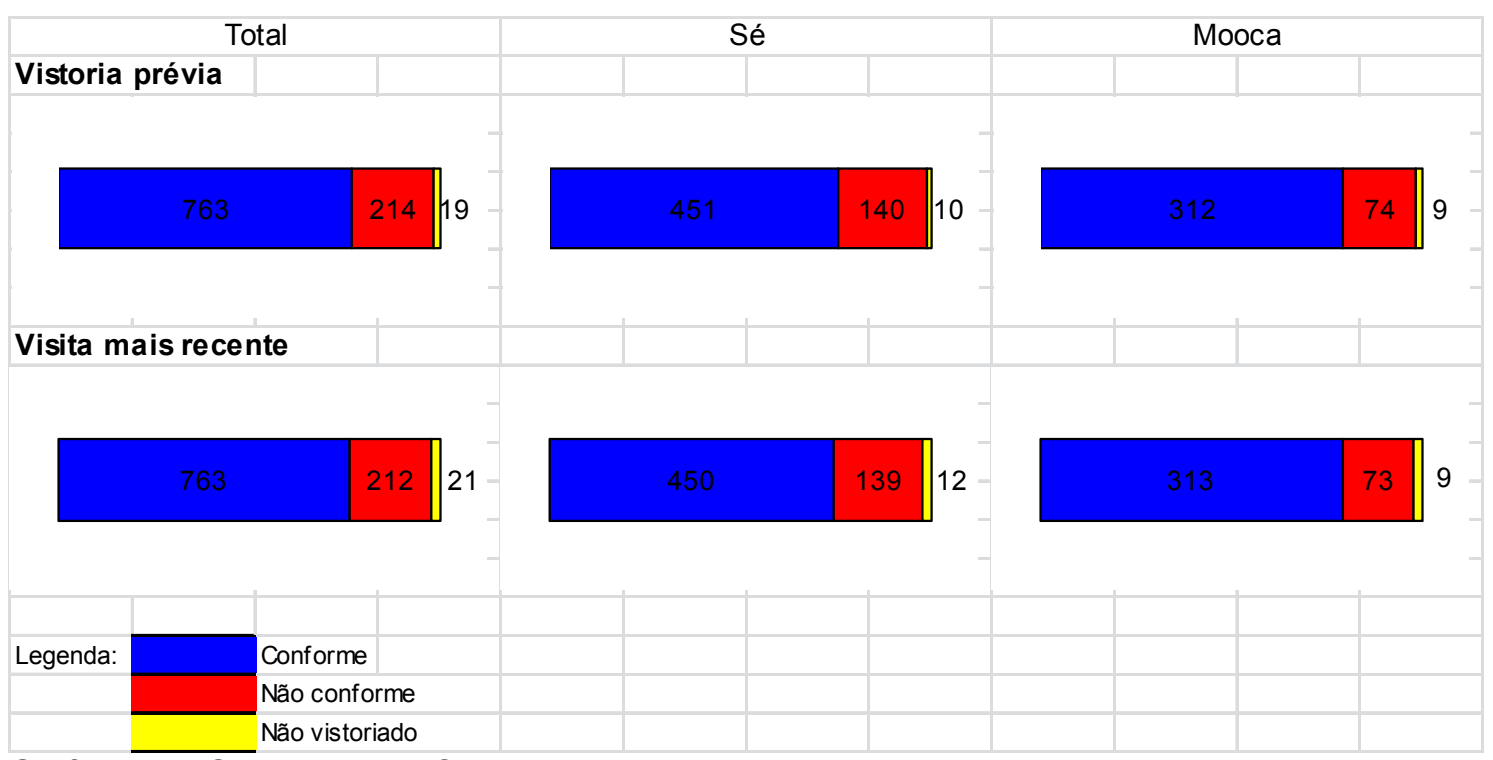

Gráfico $\overline{24-\text { Salubridade - Circulação }}$

Outras observações que merecem ser relatadas são os sinais de infiltração, que em $69 \%$ (Tabela 39) dos casos apresentam níveis preocupantes. As infiltrações no interior do cortiço somam-se à pouca ventilação e insolação. 
Tabela 39 - Caracterização dos Imóveis - Salubridade - Sinais de Infiltração

Total de cortiços em funcionamento: 987

\begin{tabular}{|c|c|c|c|c|c|}
\hline \multicolumn{2}{|c|}{ Total } & \multicolumn{2}{|c|}{ Sé } & \multicolumn{2}{|c|}{ Mooca } \\
\hline \multirow{2}{*}{$\begin{array}{c}\text { Imóveis } \\
\text { Vistoria prévia }\end{array}$} & Famílias & Imóveis & Famílias & Imóveis & Famílias \\
\hline & & & & & \\
\hline \multicolumn{6}{|l|}{ Conforme } \\
\hline 288 & 2.690 & 197 & 1.727 & 91 & 963 \\
\hline $29 \%$ & $29 \%$ & $33 \%$ & $30 \%$ & $23 \%$ & $26 \%$ \\
\hline \multicolumn{6}{|l|}{ Não conforme } \\
\hline 689 & 6.601 & 394 & 3.927 & 295 & 2.674 \\
\hline $69 \%$ & $70 \%$ & $66 \%$ & $69 \%$ & $75 \%$ & $73 \%$ \\
\hline \multicolumn{6}{|l|}{ Não vistoriado } \\
\hline 10 & 85 & 10 & 78 & 0 & 7 \\
\hline $1 \%$ & $1 \%$ & $2 \%$ & $1 \%$ & $0 \%$ & $0 \%$ \\
\hline & & & & & \\
\hline \multicolumn{6}{|c|}{ Visita mais recente } \\
\hline \multicolumn{6}{|l|}{ Conforme } \\
\hline 290 & 2.731 & 196 & 1.727 & 94 & 1.004 \\
\hline $29 \%$ & $29 \%$ & $33 \%$ & $30 \%$ & $24 \%$ & $28 \%$ \\
\hline \multicolumn{6}{|l|}{ Não conforme } \\
\hline 684 & 6.532 & 392 & 3.899 & 292 & 2.633 \\
\hline $69 \%$ & $70 \%$ & $65 \%$ & $68 \%$ & $74 \%$ & $72 \%$ \\
\hline \multicolumn{6}{|l|}{ Não vistoriado } \\
\hline 22 & 113 & 13 & 106 & 9 & 7 \\
\hline $2 \%$ & $1 \%$ & $2 \%$ & $2 \%$ & $2 \%$ & $0 \%$ \\
\hline
\end{tabular}

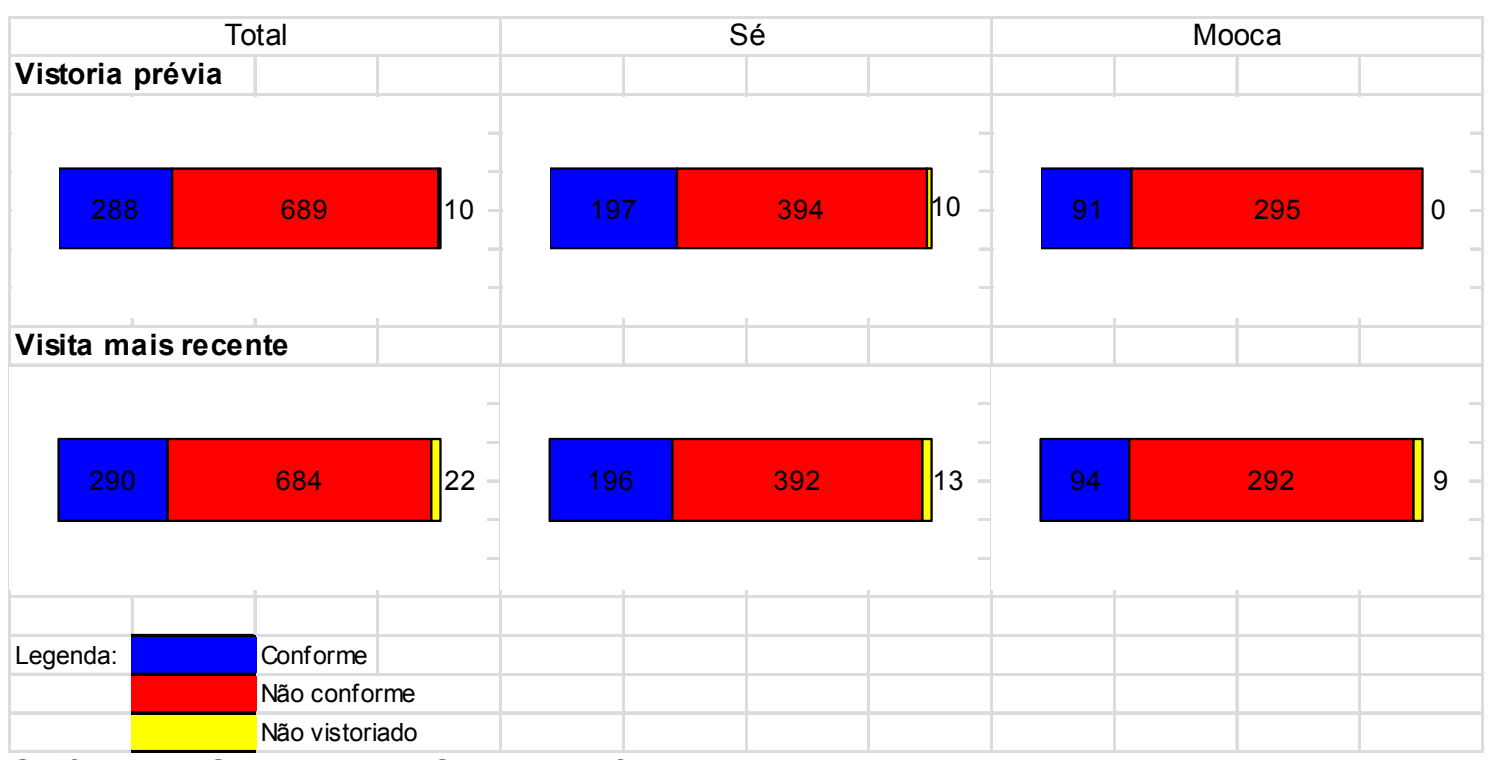

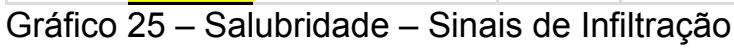

As redes internas de água e esgoto têm influência direta na insalubridade dos imóveis. Com o passar dos anos, as reformas que foram sendo realizadas para comportar o número de inquilinos desejado descaracterizaram as redes de água e esgoto. Nos casos mais graves, foram encontrados cortiços com vazamento de esgoto nas circulações do imóvel. A umidade proveniente dos vazamentos da rede 
hidráulica soma-se aos vazamentos das infiltrações, formando um quadro altamente precário, favorável à proliferação de enfermidades hidrotransmissíveis.

Vemos que $38 \%$ dos casos para a rede de água e $36 \%$ para a rede de esgoto (tabelas 40 e 41, respectivamente) não estão de acordo com as exigências da lei.

Tabela 40 - Caracterização dos Imóveis - Salubridade - Rede de Água

Total de cortiços em funcionamento: 996

\begin{tabular}{|c|c|c|c|c|c|}
\hline \multicolumn{2}{|c|}{ Total } & \multicolumn{2}{|c|}{ Sé } & \multicolumn{2}{|c|}{ Mooca } \\
\hline \multirow{2}{*}{$\frac{\text { Imóveis }}{\text { Vistoria prévia }}$} & Famílias & Imóveis & Famílias & Imóveis & Famílias \\
\hline & & & & & \\
\hline \multicolumn{6}{|l|}{ Conforme } \\
\hline 597 & 5.608 & 424 & 4.034 & 173 & 1.574 \\
\hline $60 \%$ & $60 \%$ & $71 \%$ & $70 \%$ & $44 \%$ & $43 \%$ \\
\hline \multicolumn{6}{|l|}{ Não conforme } \\
\hline 380 & 3.683 & 167 & 1.620 & 213 & 2.063 \\
\hline $38 \%$ & $39 \%$ & $28 \%$ & $28 \%$ & $54 \%$ & $57 \%$ \\
\hline \multicolumn{6}{|l|}{ Não vistoriado } \\
\hline 19 & 85 & 10 & 78 & 9 & 7 \\
\hline $2 \%$ & $1 \%$ & $2 \%$ & $1 \%$ & $2 \%$ & $0 \%$ \\
\hline & & & & & \\
\hline \multicolumn{6}{|c|}{ Visita mais recente } \\
\hline \multicolumn{6}{|l|}{ Conforme } \\
\hline 594 & 5.622 & 423 & 4.019 & 171 & 1.603 \\
\hline $60 \%$ & $60 \%$ & $70 \%$ & $70 \%$ & $43 \%$ & $44 \%$ \\
\hline \multicolumn{6}{|l|}{ Não conforme } \\
\hline 380 & 3.641 & 165 & 1.607 & 215 & 2.034 \\
\hline $38 \%$ & $39 \%$ & $27 \%$ & $28 \%$ & $54 \%$ & $56 \%$ \\
\hline \multicolumn{6}{|l|}{ Não vistoriado } \\
\hline 22 & 113 & 13 & 106 & 9 & 7 \\
\hline $2 \%$ & $1 \%$ & $2 \%$ & $2 \%$ & $2 \%$ & $0 \%$ \\
\hline
\end{tabular}

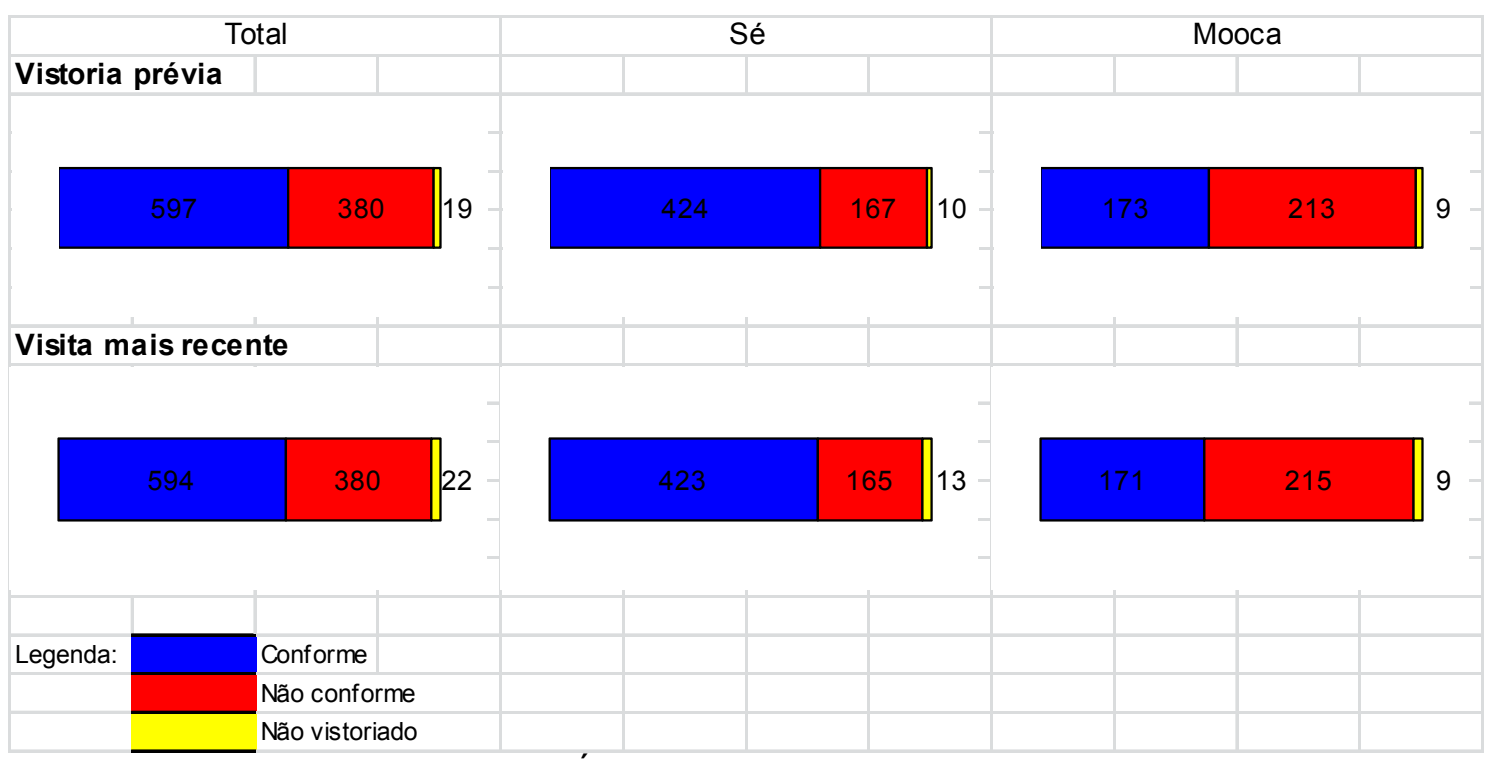

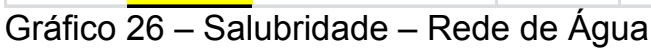


Tabela 41 - Caracterização dos Imóveis - Salubridade - Rede de Esgoto

Total de cortiços em funcionamento: 996

\begin{tabular}{|c|c|c|c|c|c|}
\hline \multicolumn{2}{|c|}{ Total } & \multicolumn{2}{|c|}{ Sé } & \multicolumn{2}{|c|}{ Mooca } \\
\hline \multirow{2}{*}{$\frac{\text { Imóveis }}{\text { Vistoria prévia }}$} & Famílias & Imóveis & Famílias & Imóveis & Famílias \\
\hline & & & & & \\
\hline \multicolumn{6}{|l|}{ Conforme } \\
\hline 616 & 5.654 & 411 & 3.738 & 205 & 1.916 \\
\hline $62 \%$ & $60 \%$ & $68 \%$ & $65 \%$ & $52 \%$ & $53 \%$ \\
\hline \multicolumn{6}{|l|}{ Não conforme } \\
\hline 361 & 3.637 & 180 & 1.916 & 181 & 1.721 \\
\hline $36 \%$ & $39 \%$ & $30 \%$ & $33 \%$ & $46 \%$ & $47 \%$ \\
\hline \multicolumn{6}{|l|}{ Não vistoriado } \\
\hline 19 & 85 & 10 & 78 & 9 & 7 \\
\hline $2 \%$ & $1 \%$ & $2 \%$ & $1 \%$ & $2 \%$ & $0 \%$ \\
\hline \multirow{2}{*}{\multicolumn{6}{|c|}{ Visita mais recente }} \\
\hline & & & & & \\
\hline \multicolumn{6}{|l|}{ Conforme } \\
\hline 620 & 5.716 & 411 & 3.749 & 209 & 1.967 \\
\hline $62 \%$ & $61 \%$ & $68 \%$ & $65 \%$ & $53 \%$ & $54 \%$ \\
\hline \multicolumn{6}{|l|}{ Não conforme } \\
\hline 354 & 3.547 & 177 & 1.877 & 177 & 1.670 \\
\hline $36 \%$ & $38 \%$ & $29 \%$ & $33 \%$ & $45 \%$ & $46 \%$ \\
\hline \multicolumn{6}{|l|}{ Não vistoriado } \\
\hline 22 & 113 & 13 & 106 & 9 & 7 \\
\hline $2 \%$ & $1 \%$ & $2 \%$ & $2 \%$ & $2 \%$ & $0 \%$ \\
\hline
\end{tabular}

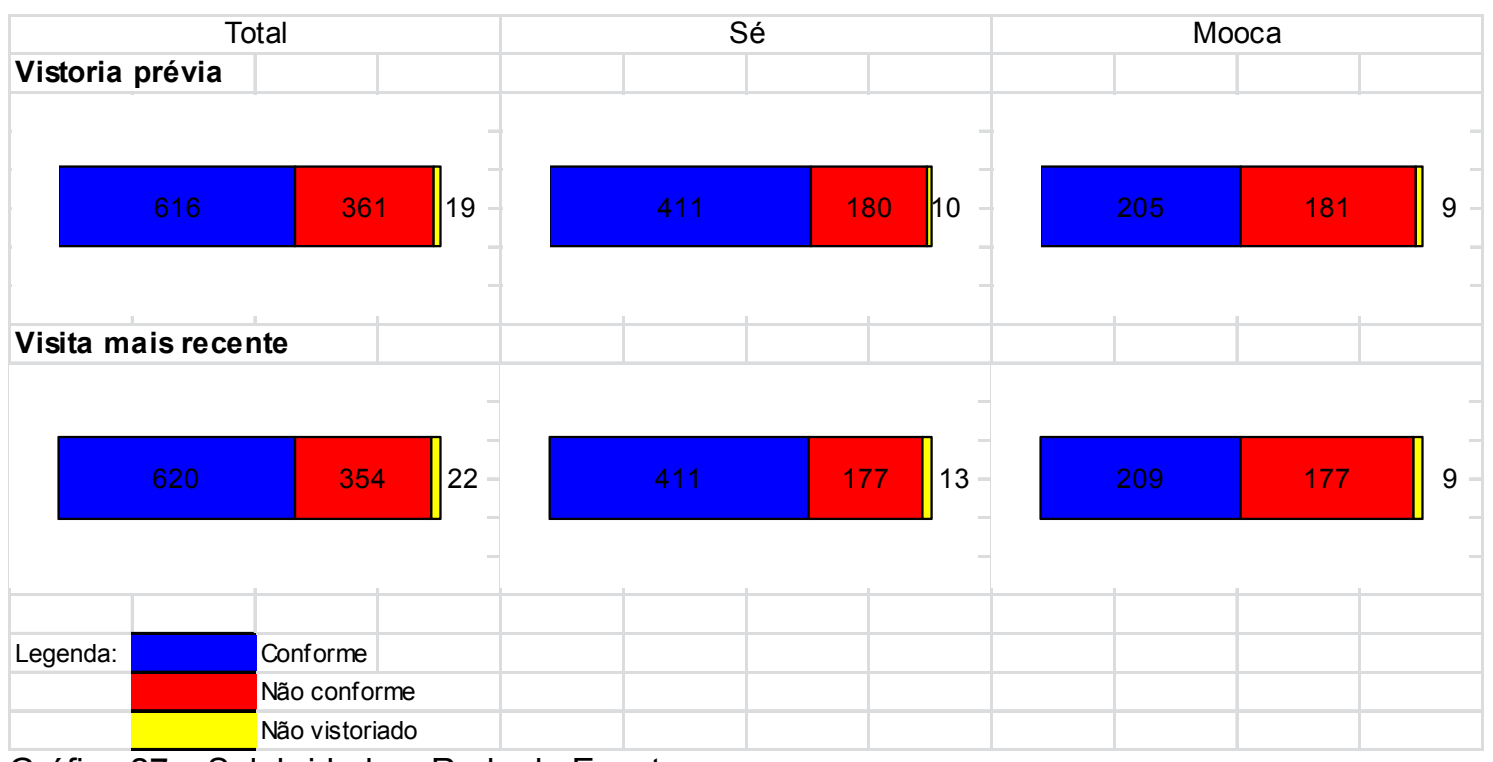

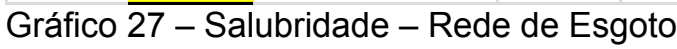

Outros itens a serem observados são as trincas e fissuras, recorrentes em $64 \%$ dos cortiços (Tabela 42). Armaduras expostas, item estrutural importante, têm uma recorrência satisfatória: apenas $20 \%$ dos cortiços apresentam problemas (Tabela 43). 
Tabela 42 - Caracterização dos Imóveis - Estrutura - Trincas

Total de cortiços em funcionamento: 996

\begin{tabular}{|c|c|c|c|c|c|}
\hline \multicolumn{2}{|c|}{ Total } & \multicolumn{2}{|c|}{ Sé } & \multicolumn{2}{|c|}{ Mooca } \\
\hline \multirow{2}{*}{$\frac{\text { Imóveis }}{\text { Vistoria prévia }}$} & Famílias & Imóveis & Famílias & Imóveis & Famílias \\
\hline & & & & & \\
\hline \multicolumn{6}{|l|}{ Conforme } \\
\hline 344 & 3.114 & 168 & 1.423 & 176 & 1.691 \\
\hline $35 \%$ & $33 \%$ & $28 \%$ & $25 \%$ & $45 \%$ & $46 \%$ \\
\hline \multicolumn{6}{|l|}{ Não conforme } \\
\hline 633 & 6.177 & 423 & 4.231 & 210 & 1.946 \\
\hline $64 \%$ & $66 \%$ & $70 \%$ & $74 \%$ & $53 \%$ & $53 \%$ \\
\hline \multicolumn{6}{|l|}{ Não vistoriado } \\
\hline 19 & 85 & 10 & 78 & 9 & 7 \\
\hline $2 \%$ & $1 \%$ & $2 \%$ & $1 \%$ & $2 \%$ & $0 \%$ \\
\hline & & & & & \\
\hline \multicolumn{6}{|c|}{ Visita mais recente } \\
\hline \multicolumn{6}{|l|}{ Conforme } \\
\hline 347 & 3.123 & 167 & 1.423 & 180 & 1.700 \\
\hline $35 \%$ & $33 \%$ & $28 \%$ & $25 \%$ & $46 \%$ & $47 \%$ \\
\hline \multicolumn{6}{|l|}{ Não conforme } \\
\hline 627 & 6.140 & 421 & 4.203 & 206 & 1.937 \\
\hline $63 \%$ & $65 \%$ & $70 \%$ & $73 \%$ & $52 \%$ & $53 \%$ \\
\hline \multicolumn{6}{|l|}{ Não vistoriado } \\
\hline 22 & 113 & 13 & 106 & 9 & 7 \\
\hline $2 \%$ & $1 \%$ & $2 \%$ & $2 \%$ & $2 \%$ & $0 \%$ \\
\hline
\end{tabular}

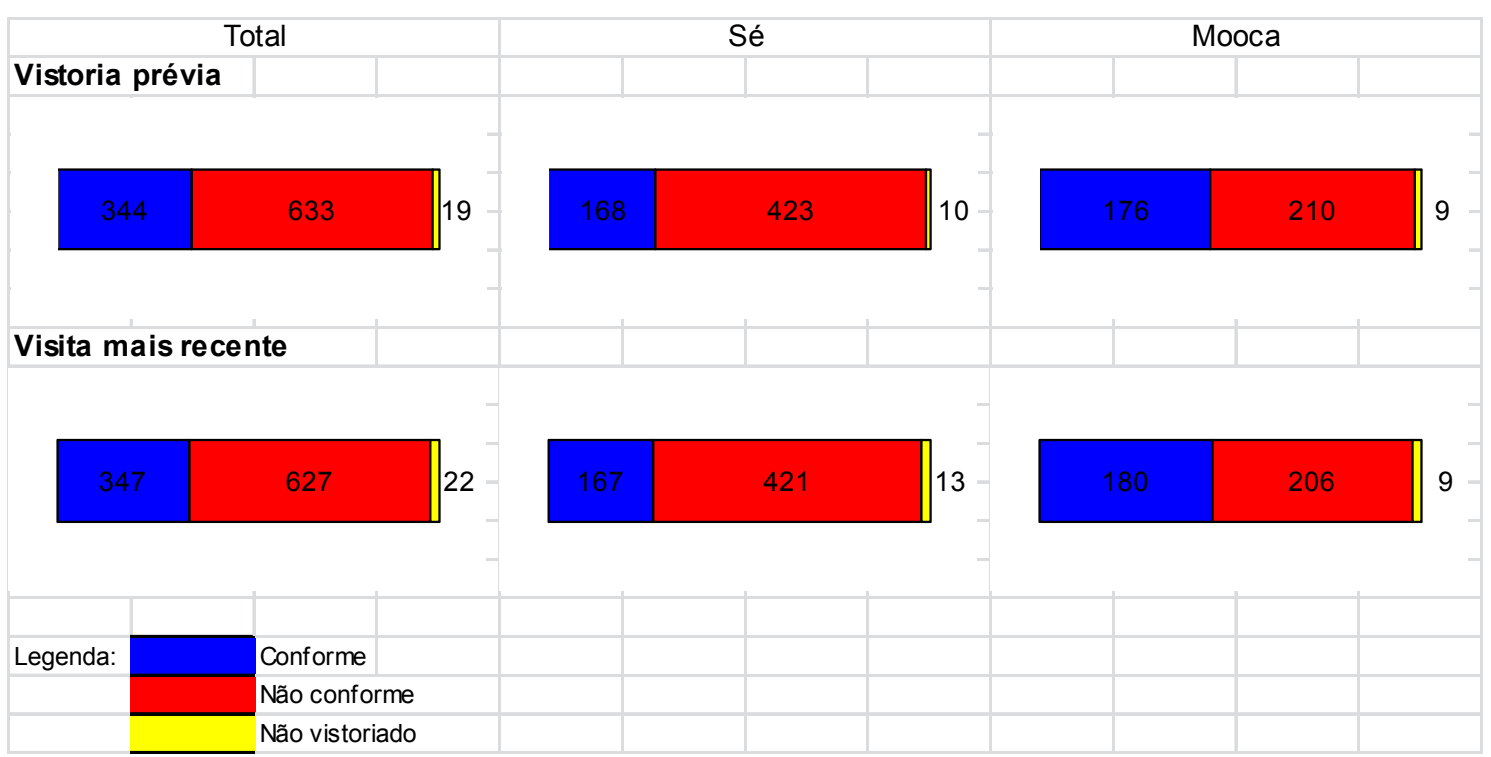

Gráfico 28 - Estrutura - Trincas 
Tabela 43 - Caracterização dos Imóveis - Estrutura - Armaduras Expostas

Total de cortiços em funcionamento: 996

\begin{tabular}{|c|c|c|c|c|c|}
\hline \multicolumn{2}{|c|}{ Total } & \multicolumn{2}{|c|}{ Sé } & \multicolumn{2}{|c|}{ Mooca } \\
\hline \multirow{2}{*}{$\begin{array}{c}\text { Imóveis } \\
\text { Vistoria prévia }\end{array}$} & Famílias & Imóveis & Famílias & Imóveis & Famílias \\
\hline & & & & & \\
\hline \multicolumn{6}{|l|}{ Conforme } \\
\hline 781 & 7.206 & 455 & 4.275 & 326 & 2.931 \\
\hline $78 \%$ & $77 \%$ & $76 \%$ & $75 \%$ & $83 \%$ & $80 \%$ \\
\hline \multicolumn{6}{|l|}{ Não conforme } \\
\hline 196 & 2.085 & 136 & 1.379 & 60 & 706 \\
\hline $20 \%$ & $22 \%$ & $23 \%$ & $24 \%$ & $15 \%$ & $19 \%$ \\
\hline \multicolumn{6}{|l|}{ Não vistoriado } \\
\hline 19 & 85 & 10 & 78 & 9 & 7 \\
\hline $2 \%$ & $1 \%$ & $2 \%$ & $1 \%$ & $2 \%$ & $0 \%$ \\
\hline & & & & & \\
\hline \multicolumn{6}{|c|}{ Visita mais recente } \\
\hline \multicolumn{6}{|l|}{ Conforme } \\
\hline 782 & 7.180 & 454 & 4.271 & 328 & 2.909 \\
\hline $79 \%$ & $77 \%$ & $76 \%$ & $75 \%$ & $83 \%$ & $80 \%$ \\
\hline \multicolumn{6}{|l|}{ Não conforme } \\
\hline 192 & 2.083 & 134 & 1.355 & 58 & 728 \\
\hline $19 \%$ & $22 \%$ & $22 \%$ & $24 \%$ & $15 \%$ & $20 \%$ \\
\hline \multicolumn{6}{|l|}{ Não vistoriado } \\
\hline 22 & 113 & 13 & 106 & 9 & 7 \\
\hline $2 \%$ & $1 \%$ & $2 \%$ & $2 \%$ & $2 \%$ & $0 \%$ \\
\hline
\end{tabular}

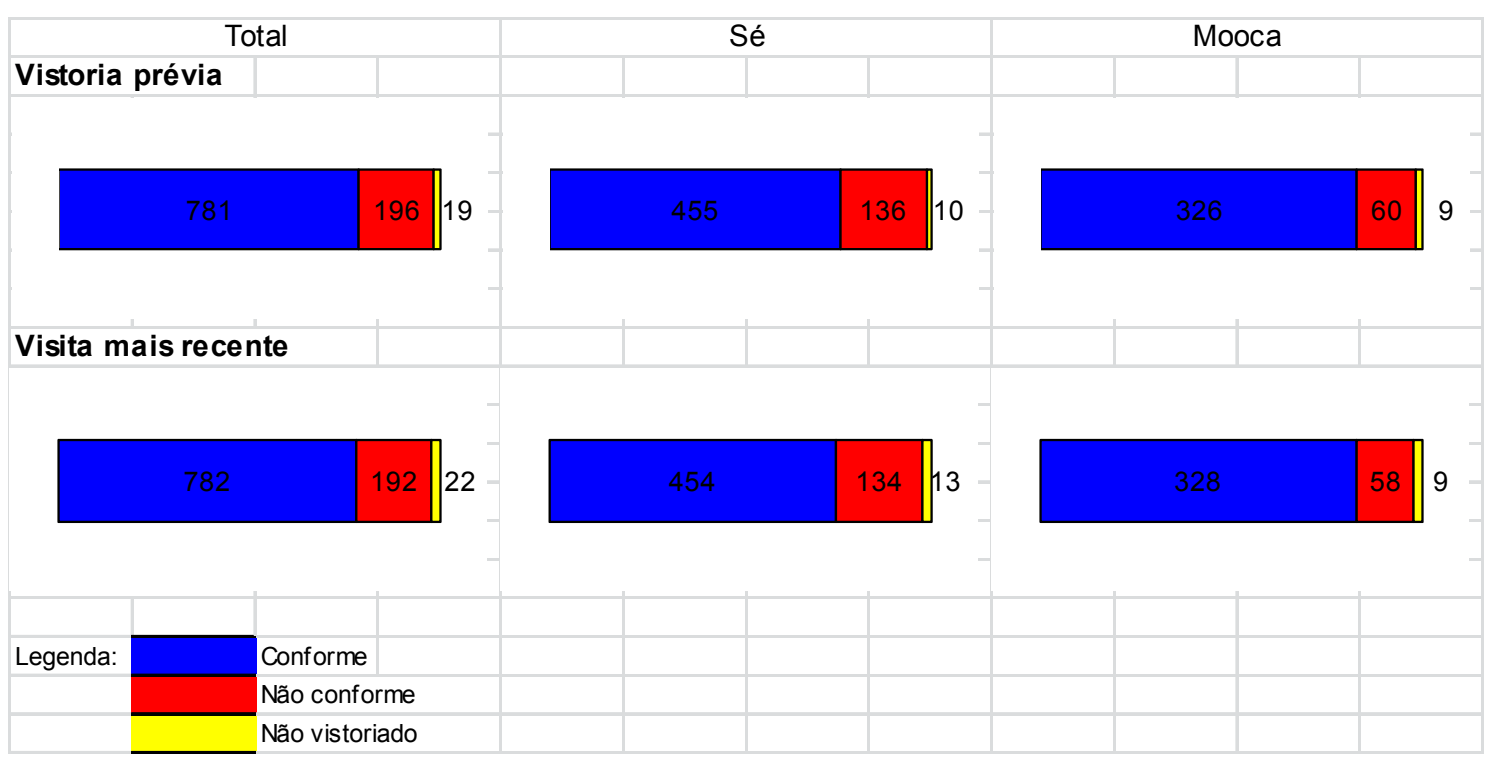

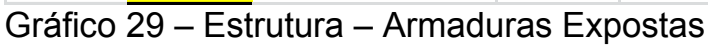

O desmantelamento dos forros de estuque é problema recorrente em $74 \%$ dos imóveis (Tabela 44). E os telhados, que têm relação direta com os sinais de infiltração e umidade no interior dos imóveis, se encontram em más condições em pelo menos $63 \%$ desses imóveis (Tabela 45). 
Tabela 44 - Caracterização dos Imóveis - Estrutura - Forro

Total de cortiços em funcionamento: 996

\begin{tabular}{|c|c|c|c|c|c|}
\hline \multicolumn{2}{|c|}{ Total } & \multicolumn{2}{|c|}{ Sé } & \multicolumn{2}{|c|}{ Mooca } \\
\hline \multirow{2}{*}{$\frac{\text { Imóveis }}{\text { Vistoria prévia }}$} & Famílias & Imóveis & Famílias & Imóveis & Famílias \\
\hline & & & & & \\
\hline \multicolumn{6}{|l|}{ Conforme } \\
\hline 240 & 2.062 & 138 & 1.112 & 102 & 950 \\
\hline $24 \%$ & $22 \%$ & $23 \%$ & $19 \%$ & $26 \%$ & $26 \%$ \\
\hline \multicolumn{6}{|l|}{ Não conforme } \\
\hline 737 & 7.229 & 453 & 4.542 & 284 & 2.687 \\
\hline $74 \%$ & $77 \%$ & $75 \%$ & $79 \%$ & $72 \%$ & $74 \%$ \\
\hline \multicolumn{6}{|l|}{ Não vistoriado } \\
\hline 19 & 85 & 10 & 78 & 9 & 7 \\
\hline $2 \%$ & $1 \%$ & $2 \%$ & $1 \%$ & $2 \%$ & $0 \%$ \\
\hline & & & & & \\
\hline \multicolumn{6}{|c|}{ Visita mais recente } \\
\hline \multicolumn{6}{|l|}{ Conforme } \\
\hline 245 & 2.086 & 139 & 1.117 & 106 & 969 \\
\hline $25 \%$ & $22 \%$ & $23 \%$ & $19 \%$ & $27 \%$ & $27 \%$ \\
\hline \multicolumn{6}{|l|}{ Não conforme } \\
\hline 729 & 7.177 & 449 & 4.509 & 280 & 2.668 \\
\hline $73 \%$ & $77 \%$ & $75 \%$ & $79 \%$ & $71 \%$ & $73 \%$ \\
\hline \multicolumn{6}{|l|}{ Não vistoriado } \\
\hline 22 & 113 & 13 & 106 & 9 & 7 \\
\hline $2 \%$ & $1 \%$ & $2 \%$ & $2 \%$ & $2 \%$ & $0 \%$ \\
\hline
\end{tabular}

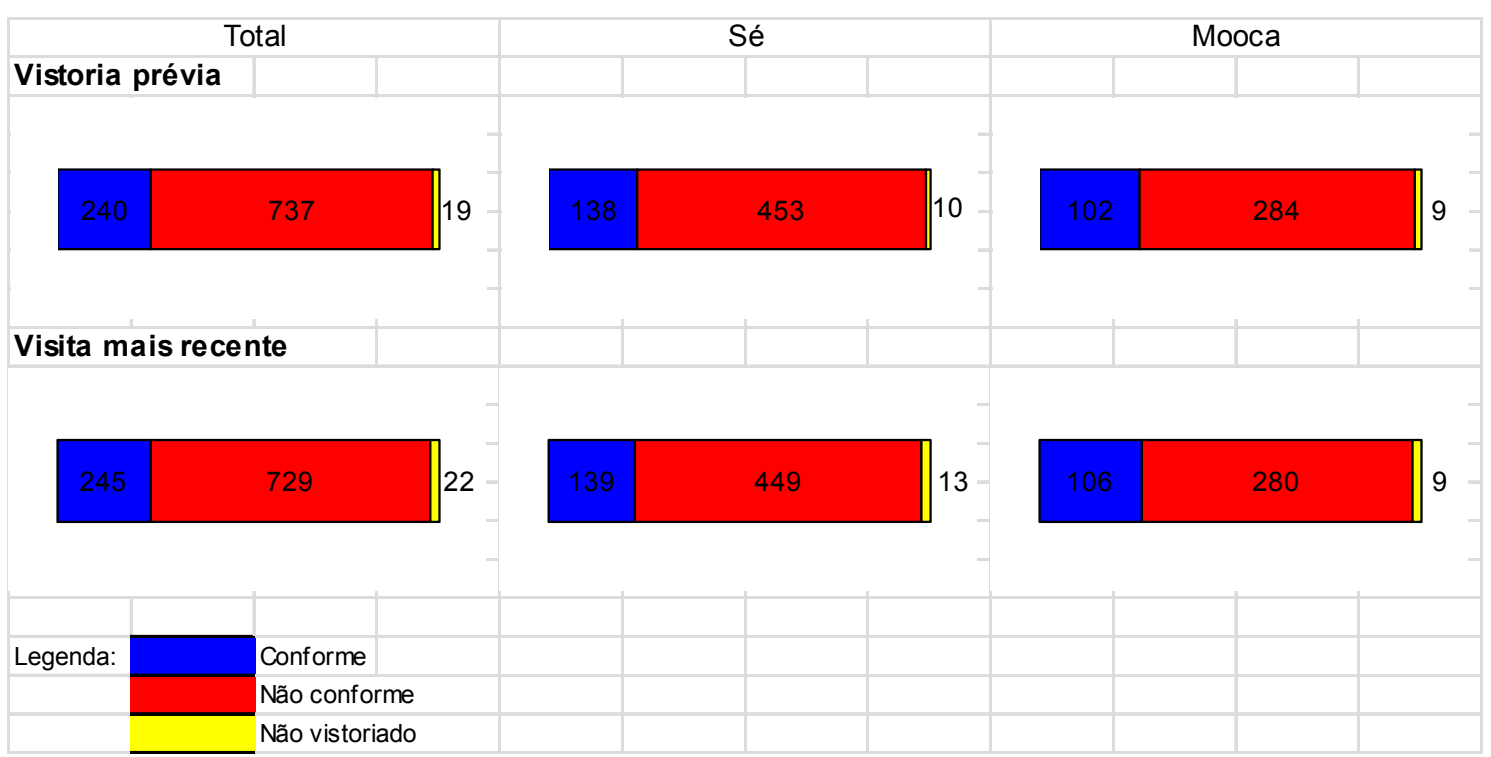

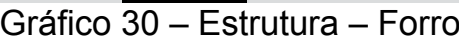


Tabela 45 - Caracterização dos Imóveis - Estrutura - Telhado

Total de cortiços em funcionamento: 996

\begin{tabular}{|c|c|c|c|c|c|}
\hline \multicolumn{2}{|c|}{ Total } & \multicolumn{2}{|c|}{ Sé } & \multicolumn{2}{|c|}{ Mooca } \\
\hline \multirow{2}{*}{$\frac{\text { Imóveis }}{\text { Vistoria prévia }}$} & Famílias & Imóveis & Famílias & Imóveis & Famílias \\
\hline & & & & & \\
\hline \multicolumn{6}{|l|}{ Conforme } \\
\hline 353 & 3.274 & 242 & 2.232 & 111 & 1.042 \\
\hline $35 \%$ & $35 \%$ & $40 \%$ & $39 \%$ & $28 \%$ & $29 \%$ \\
\hline \multicolumn{6}{|l|}{ Não conforme } \\
\hline 624 & 6.017 & 349 & 3.422 & 275 & 2.595 \\
\hline $63 \%$ & $64 \%$ & $58 \%$ & $60 \%$ & $70 \%$ & $71 \%$ \\
\hline \multicolumn{6}{|l|}{ Não vistoriado } \\
\hline 19 & 85 & 10 & 78 & 9 & 7 \\
\hline $2 \%$ & $1 \%$ & $2 \%$ & $1 \%$ & $2 \%$ & $0 \%$ \\
\hline & & & & & \\
\hline \multicolumn{6}{|c|}{ Visita mais recente } \\
\hline \multicolumn{6}{|l|}{ Conforme } \\
\hline 356 & 3.331 & 242 & 2.237 & 114 & 1.094 \\
\hline $36 \%$ & $36 \%$ & $40 \%$ & $39 \%$ & $29 \%$ & $30 \%$ \\
\hline \multicolumn{6}{|l|}{ Não conforme } \\
\hline 617 & 5.929 & 346 & 3.389 & 271 & 2.540 \\
\hline $62 \%$ & $63 \%$ & $58 \%$ & $59 \%$ & $69 \%$ & $70 \%$ \\
\hline \multicolumn{6}{|l|}{ Não vistoriado } \\
\hline 22 & 113 & 13 & 106 & 9 & 7 \\
\hline $2 \%$ & $1 \%$ & $2 \%$ & $2 \%$ & $2 \%$ & $0 \%$ \\
\hline
\end{tabular}

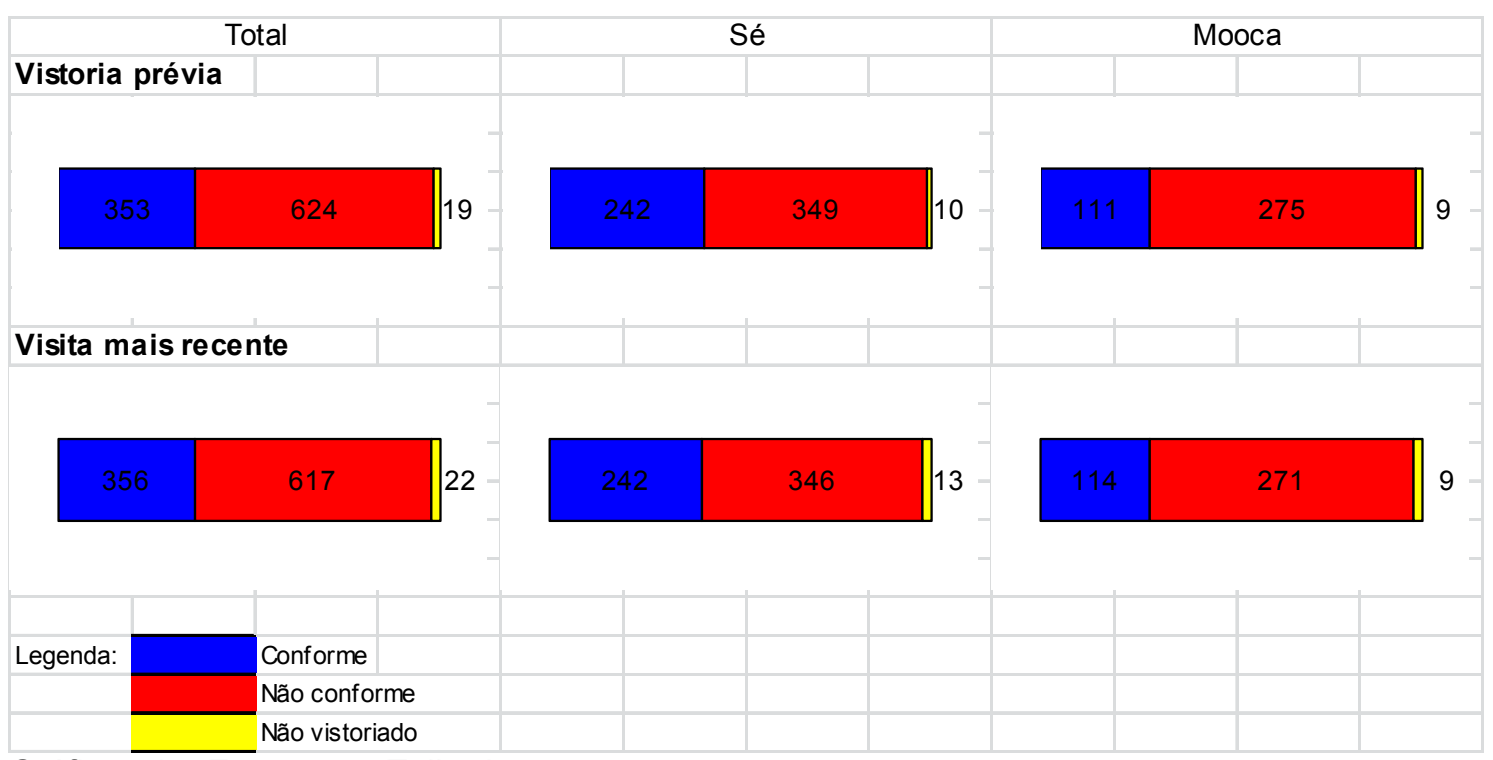

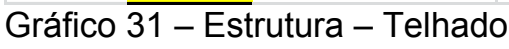

Quanto aos itens de segurança para a prevenção de incêndios, os cortiços da área central apresentam dados que requerem atenção: em 51\% (Tabela 46) dos imóveis são utilizadas divisórias de materiais inflamáveis para aumentar a quantidade de cômodos. Essas divisórias somam-se a uma grande quantidade de outros materiais inflamáveis, geralmente encontrados nessas habitações, provenientes de atividades de catação de lixo nas ruas realizadas por moradores. 
Cerca de 31\% (Tabela 47) dos imóveis encortiçados das regiões da Sé e Mooca apresentam essas características e colocam o cortiço em risco iminente de incêndio, e apenas $6 \%$ dos imóveis vistoriados apresentam extintores de incêndio devidamente instalados (Tabela 48).

Tabela 46 - Caracterização dos Imóveis - Incêndio - Vedação Total de cortiços em funcionamento: 987

\begin{tabular}{|c|c|c|c|c|c|}
\hline \multicolumn{2}{|c|}{ Total } & \multicolumn{2}{|c|}{ Sé } & \multicolumn{2}{|c|}{ Mooca } \\
\hline \multirow{2}{*}{$\begin{array}{c}\text { Imóveis } \\
\text { Vistoria prévia }\end{array}$} & Famílias & Imóveis & Famílias & Imóveis & Famílias \\
\hline & & & & & \\
\hline \multicolumn{6}{|l|}{ Conforme } \\
\hline 467 & 4373 & 263 & 2350 & 204 & 2023 \\
\hline $47 \%$ & $47 \%$ & $44 \%$ & $41 \%$ & $52 \%$ & $56 \%$ \\
\hline \multicolumn{6}{|l|}{ Não conforme } \\
\hline 510 & 4918 & 328 & 3304 & 182 & 1614 \\
\hline $51 \%$ & $52 \%$ & $55 \%$ & $58 \%$ & $46 \%$ & $44 \%$ \\
\hline \multicolumn{6}{|l|}{ Não vistoriado } \\
\hline 10 & 85 & 10 & 78 & 0 & 7 \\
\hline $1 \%$ & $1 \%$ & $2 \%$ & $1 \%$ & $0 \%$ & $0 \%$ \\
\hline \multirow{2}{*}{\multicolumn{6}{|c|}{ Visita mais recente }} \\
\hline & & & & & \\
\hline \multicolumn{6}{|l|}{ Conforme } \\
\hline 468 & 4369 & 262 & 2333 & 206 & 2036 \\
\hline $47 \%$ & $47 \%$ & $44 \%$ & $41 \%$ & $52 \%$ & $56 \%$ \\
\hline Não conforme & & & & & \\
\hline 506 & 4894 & 326 & 3293 & 180 & 1601 \\
\hline $51 \%$ & $52 \%$ & $54 \%$ & $57 \%$ & $46 \%$ & $44 \%$ \\
\hline Não vistoriado & & & & & \\
\hline 22 & 113 & 13 & 106 & 9 & 7 \\
\hline $2 \%$ & $1 \%$ & $2 \%$ & $2 \%$ & $2 \%$ & $0 \%$ \\
\hline
\end{tabular}

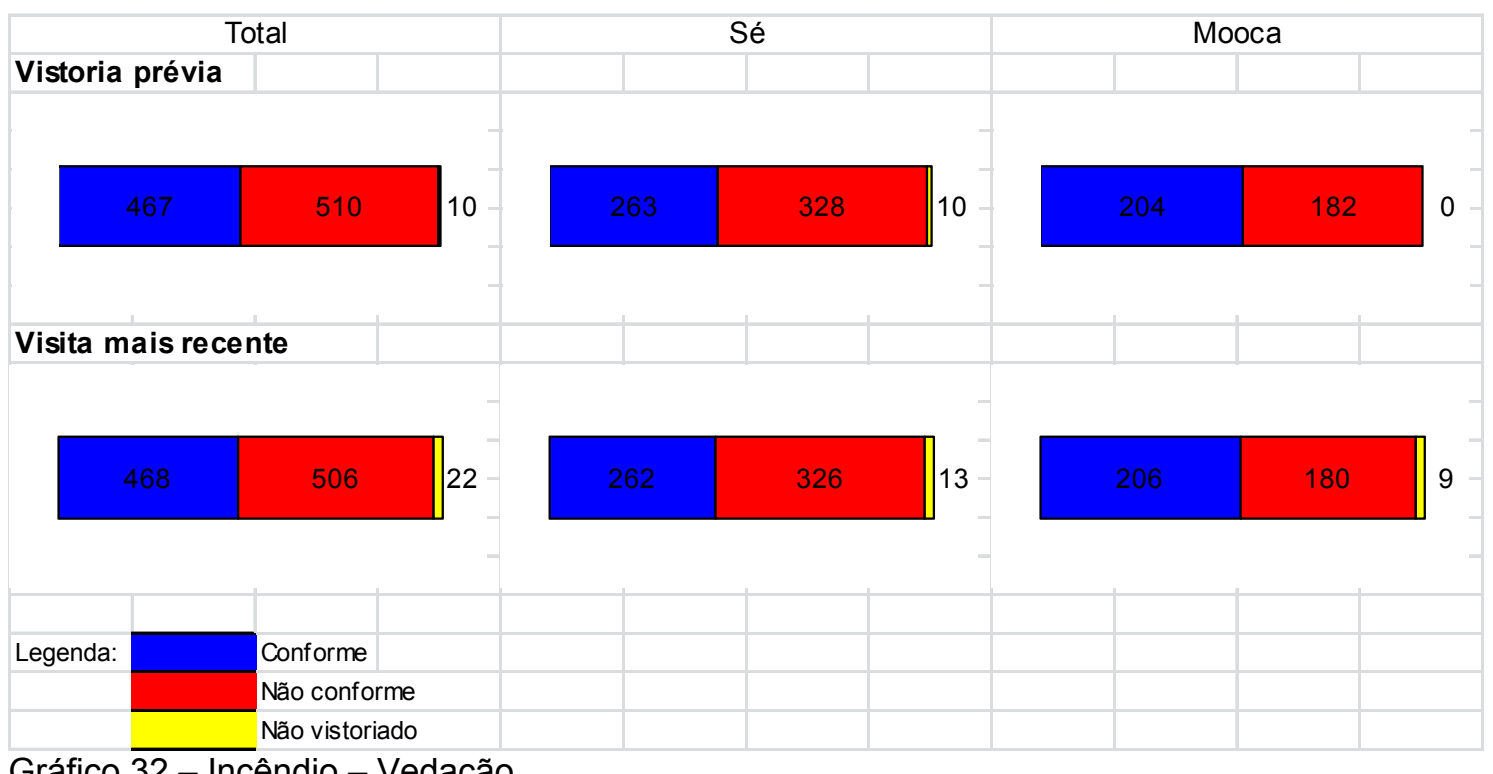

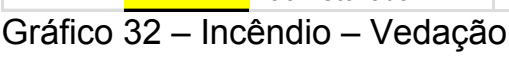


Tabela 47 - Caracterização dos Imóveis - Incêndio - Material Inflamável

Total de cortiços em funcionamento: 996

\begin{tabular}{|c|c|c|c|c|c|}
\hline \multicolumn{2}{|c|}{ Total } & \multicolumn{2}{|c|}{ Sé } & \multicolumn{2}{|c|}{ Mooca } \\
\hline \multirow{2}{*}{$\frac{\text { Imóveis }}{\text { Vistoria prévia }}$} & Famílias & Imóveis & Famílias & Imóveis & Famílias \\
\hline & & & & & \\
\hline \multicolumn{6}{|l|}{ Conforme } \\
\hline 671 & 6.529 & 452 & 4.356 & 219 & 2.173 \\
\hline $67 \%$ & $70 \%$ & $75 \%$ & $76 \%$ & $55 \%$ & $60 \%$ \\
\hline \multicolumn{6}{|l|}{ Não conforme } \\
\hline 306 & 2.762 & 139 & 1.298 & 167 & 1.464 \\
\hline $31 \%$ & $29 \%$ & $23 \%$ & $23 \%$ & $42 \%$ & $40 \%$ \\
\hline \multicolumn{6}{|l|}{ Não vistoriado } \\
\hline 19 & 85 & 10 & 78 & 9 & 7 \\
\hline $2 \%$ & $1 \%$ & $2 \%$ & $1 \%$ & $2 \%$ & $0 \%$ \\
\hline & & & & & \\
\hline \multicolumn{6}{|c|}{ Visita mais recente } \\
\hline \multicolumn{6}{|l|}{ Conforme } \\
\hline 677 & 6.575 & 450 & 4.328 & 227 & 2.247 \\
\hline $68 \%$ & $70 \%$ & $75 \%$ & $76 \%$ & $57 \%$ & $62 \%$ \\
\hline \multicolumn{6}{|l|}{ Não conforme } \\
\hline 297 & 2.688 & 138 & 1.298 & 159 & 1.390 \\
\hline $30 \%$ & $29 \%$ & $23 \%$ & $23 \%$ & $40 \%$ & $38 \%$ \\
\hline \multicolumn{6}{|l|}{ Não vistoriado } \\
\hline 22 & 113 & 13 & 106 & 9 & 7 \\
\hline $2 \%$ & $1 \%$ & $2 \%$ & $2 \%$ & $2 \%$ & $0 \%$ \\
\hline
\end{tabular}

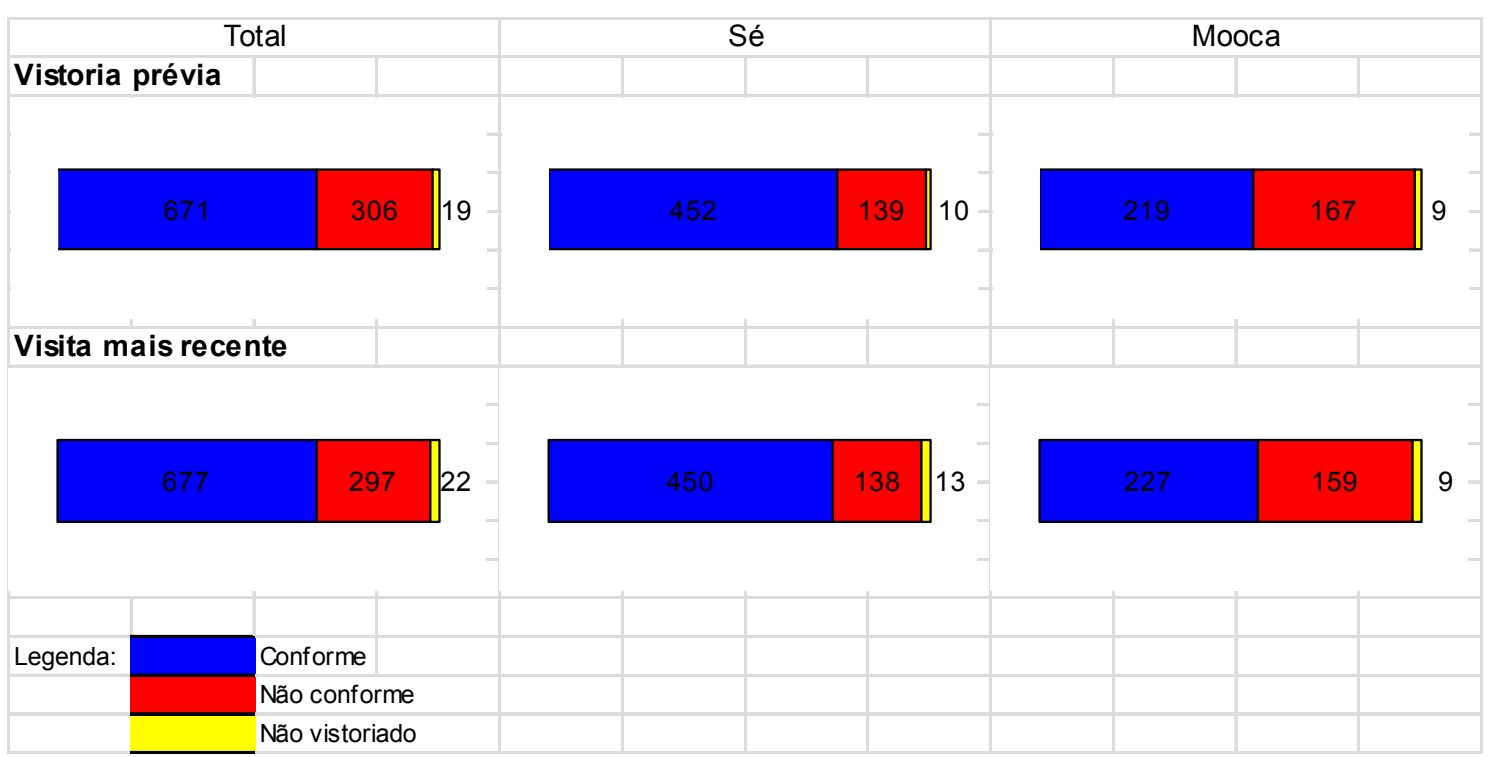

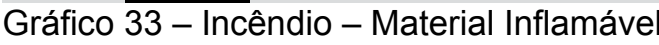


Tabela 48 - Caracterização dos Imóveis - Incêndio - Extintores

Total de cortiços em funcionamento: 996

\begin{tabular}{|c|c|c|c|c|c|}
\hline \multicolumn{2}{|c|}{ Total } & \multicolumn{2}{|c|}{ Sé } & \multicolumn{2}{|c|}{ Mooca } \\
\hline \multirow{2}{*}{$\frac{\text { Imóveis }}{\text { Vistoria prévia }}$} & Famílias & Imóveis & Famílias & Imóveis & \multirow[t]{2}{*}{ Famílias } \\
\hline & & & & & \\
\hline \multicolumn{6}{|l|}{ Conforme } \\
\hline 57 & 748 & 36 & 432 & 21 & 316 \\
\hline $6 \%$ & $8 \%$ & $6 \%$ & $8 \%$ & $5 \%$ & $9 \%$ \\
\hline \multicolumn{6}{|l|}{ Não conforme } \\
\hline 920 & 8.543 & 555 & 5.222 & 365 & 3.321 \\
\hline $92 \%$ & $91 \%$ & $92 \%$ & $91 \%$ & $92 \%$ & $91 \%$ \\
\hline \multicolumn{6}{|l|}{ Não vistoriado } \\
\hline 19 & 85 & 10 & 78 & 9 & 7 \\
\hline $2 \%$ & $1 \%$ & $2 \%$ & $1 \%$ & $2 \%$ & $0 \%$ \\
\hline & & & & & \\
\hline \multicolumn{6}{|c|}{ Visita mais recente } \\
\hline \multicolumn{6}{|l|}{ Conforme } \\
\hline 62 & 825 & 36 & 432 & 26 & 393 \\
\hline $6 \%$ & $9 \%$ & $6 \%$ & $8 \%$ & $7 \%$ & $11 \%$ \\
\hline \multicolumn{6}{|l|}{ Não conforme } \\
\hline 912 & 8.438 & 552 & 5.194 & 360 & 3.244 \\
\hline $92 \%$ & $90 \%$ & $92 \%$ & $91 \%$ & $91 \%$ & $89 \%$ \\
\hline \multicolumn{6}{|l|}{ Não vistoriado } \\
\hline 22 & 113 & 13 & 106 & 9 & 7 \\
\hline $2 \%$ & $1 \%$ & $2 \%$ & $2 \%$ & $2 \%$ & $0 \%$ \\
\hline
\end{tabular}

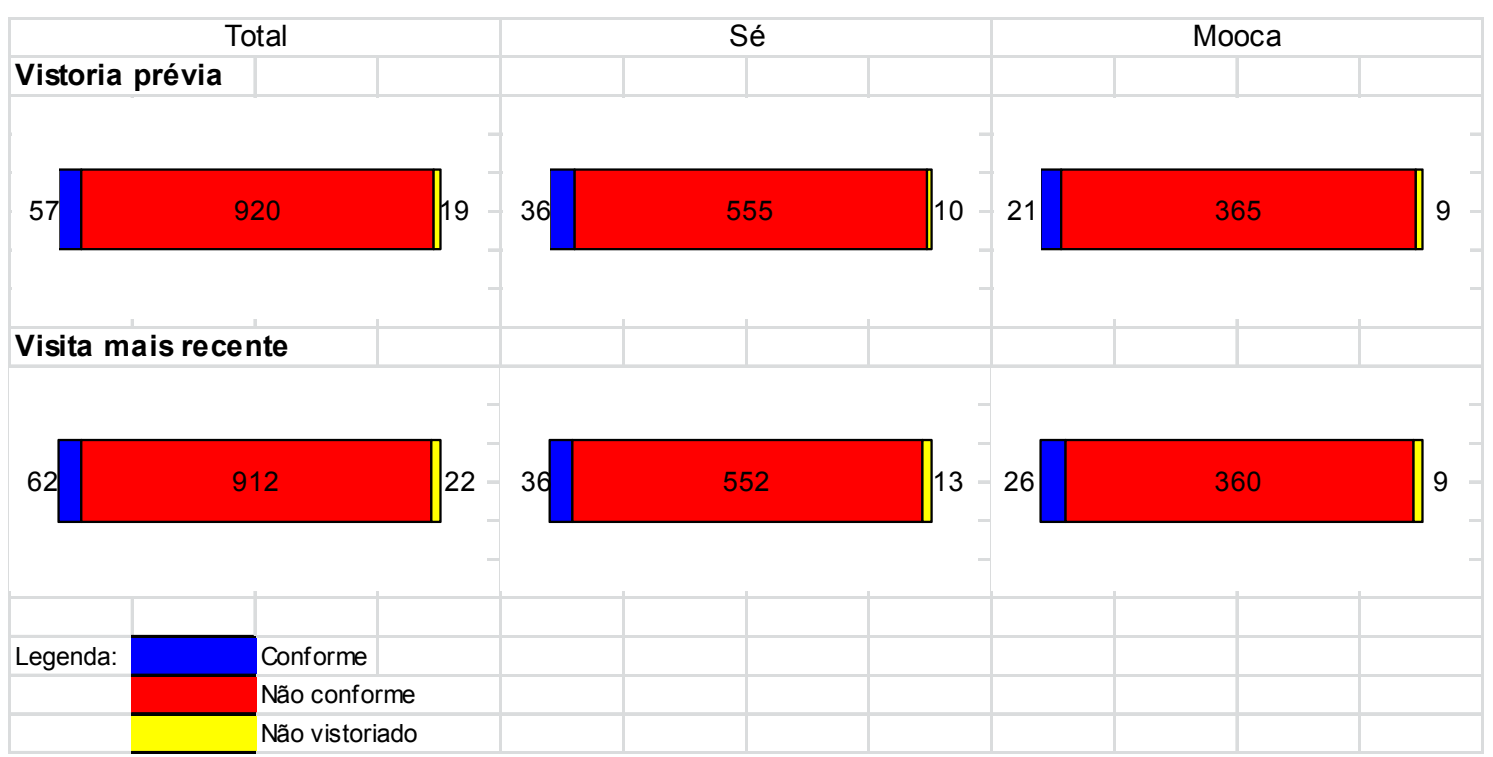

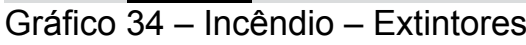

Um dado alarmante é o acondicionamento dos botijões de gás. Em 92\% dos casos, o botijão se encontra dentro dos cômodos dos cortiços (Tabela 49). É uma situação extremamente delicada, levando em consideração a área pequena dos cômodos em um caso de vazamento de gás. 
Tabela 49 - Caracterização dos Imóveis - Incêndio - Localização dos Botijões

Total de cortiços em funcionamento: 996

\begin{tabular}{|c|c|c|c|c|c|}
\hline \multicolumn{2}{|c|}{ Total } & \multicolumn{2}{|c|}{ Sé } & \multicolumn{2}{|c|}{ Mooca } \\
\hline \multirow{2}{*}{$\begin{array}{c}\text { Imóveis } \\
\text { Vistoria prévia }\end{array}$} & Famílias & Imóveis & Famílias & Imóveis & Famílias \\
\hline & & & & & \\
\hline \multicolumn{6}{|l|}{ Conforme } \\
\hline 61 & 559 & 30 & 191 & 31 & 368 \\
\hline $6 \%$ & $6 \%$ & $5 \%$ & $3 \%$ & $8 \%$ & $10 \%$ \\
\hline \multicolumn{6}{|l|}{ Não conforme } \\
\hline 916 & 8.732 & 561 & 5.463 & 355 & 3.269 \\
\hline $92 \%$ & $93 \%$ & $93 \%$ & $95 \%$ & $90 \%$ & $90 \%$ \\
\hline \multicolumn{6}{|l|}{ Não vistoriado } \\
\hline 19 & 85 & 10 & 78 & 9 & 7 \\
\hline $2 \%$ & $1 \%$ & $2 \%$ & $1 \%$ & $2 \%$ & $0 \%$ \\
\hline & & & & & \\
\hline \multicolumn{6}{|c|}{ Visita mais recente } \\
\hline \multicolumn{6}{|l|}{ Conforme } \\
\hline 68 & 695 & 29 & 189 & 39 & 506 \\
\hline $7 \%$ & $7 \%$ & $5 \%$ & $3 \%$ & $10 \%$ & $14 \%$ \\
\hline \multicolumn{6}{|l|}{ Não conforme } \\
\hline 906 & 8.568 & 559 & 5.437 & 347 & 3.131 \\
\hline $91 \%$ & $91 \%$ & $93 \%$ & $95 \%$ & $88 \%$ & $86 \%$ \\
\hline \multicolumn{6}{|l|}{ Não vistoriado } \\
\hline 22 & 113 & 13 & 106 & 9 & 7 \\
\hline $2 \%$ & $1 \%$ & $2 \%$ & $2 \%$ & $2 \%$ & $0 \%$ \\
\hline
\end{tabular}

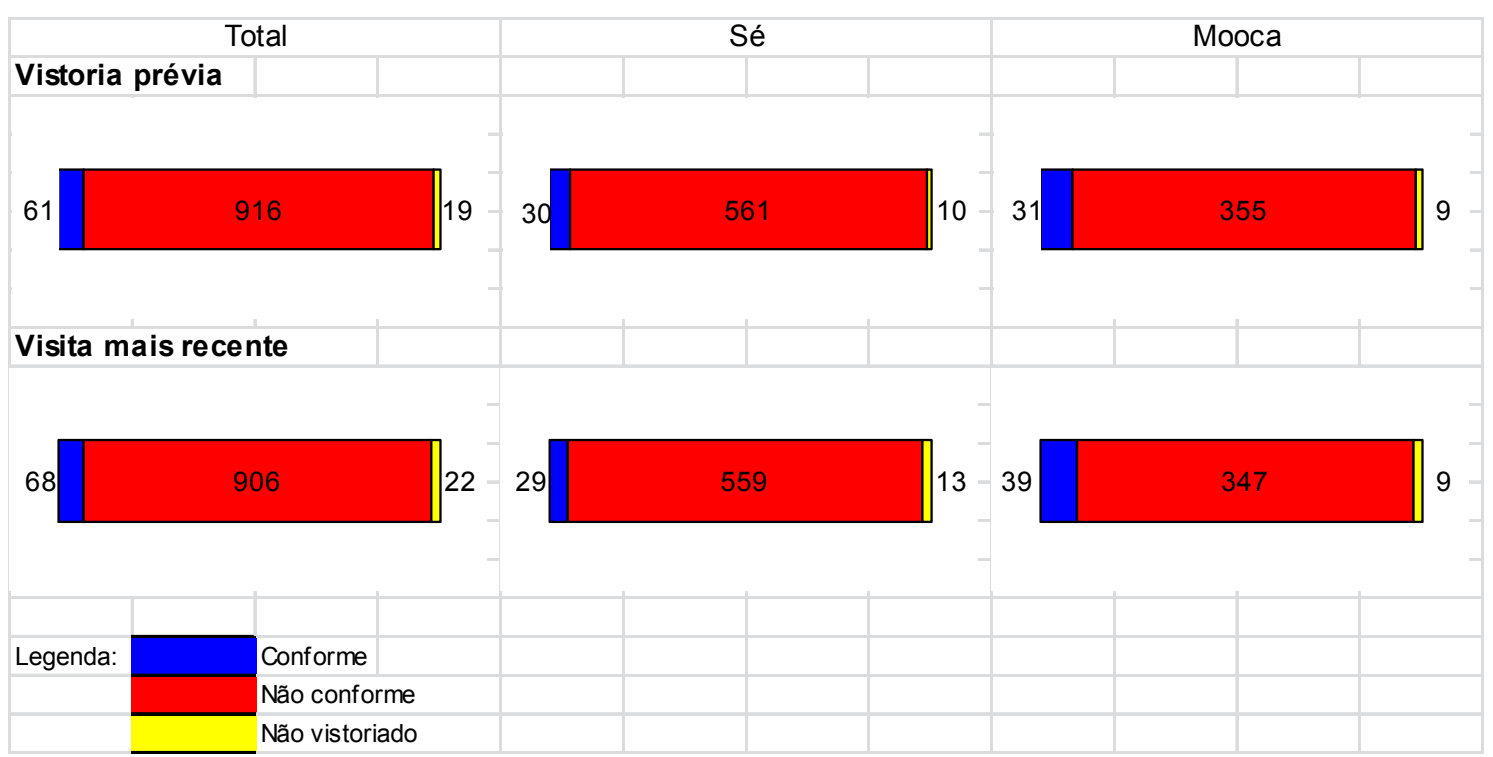

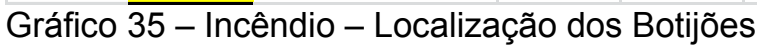

Há outros fatores que aumentam o risco de incêndio. A rede elétrica interna, por exemplo, em $80 \%$ dos casos, encontra-se fora dos padrões adequados. Em geral, os fios e cabeamentos estão expostos, fora de canaletas apropriadas para o seu acondicionamento e, inclusive, fora das normas atuais de dimensionamento de fios, segundo a amperagem e voltagem. O mesmo ocorre com o quadro de luz, que em $43 \%$ dos casos está irregular, com disjuntores antigos fora das normas vigentes, 
e as tomadas são utilizadas para o uso de diversos aparelhos eletroeletrônicas ao mesmo tempo (tabelas 50, 51 e 52, respectivamente).

Tabela 50 - Caracterização dos Imóveis - Incêndio - Rede Elétrica Interna Total de cortiços em funcionamento: 996

\begin{tabular}{|c|c|c|c|c|c|}
\hline \multicolumn{2}{|c|}{ Total } & \multicolumn{2}{|c|}{ Sé } & \multicolumn{2}{|c|}{ Mooca } \\
\hline Imóveis & Famílias & Imóveis & Famílias & Imóveis & Famílias \\
\hline \multicolumn{6}{|l|}{ Vistoria prévia } \\
\hline \multicolumn{6}{|l|}{ Conforme } \\
\hline 180 & 1.793 & 113 & 972 & 67 & 821 \\
\hline $18 \%$ & $19 \%$ & $19 \%$ & $17 \%$ & $17 \%$ & $23 \%$ \\
\hline \multicolumn{6}{|l|}{ Não conforme } \\
\hline 797 & 7.498 & 478 & 4.682 & 319 & 2.816 \\
\hline $80 \%$ & $80 \%$ & $80 \%$ & $82 \%$ & $81 \%$ & $77 \%$ \\
\hline \multicolumn{6}{|l|}{ Não vistoriado } \\
\hline 19 & 85 & 10 & 78 & 9 & 7 \\
\hline $2 \%$ & $1 \%$ & $2 \%$ & $1 \%$ & $2 \%$ & $0 \%$ \\
\hline & & & & & \\
\hline \multicolumn{6}{|c|}{ Visita mais recente } \\
\hline \multicolumn{6}{|c|}{\begin{tabular}{|l|l} 
Conforme \\
\end{tabular}} \\
\hline 187 & 1.868 & 113 & 972 & 74 & 896 \\
\hline $19 \%$ & $20 \%$ & $19 \%$ & $17 \%$ & $19 \%$ & $25 \%$ \\
\hline \multicolumn{6}{|l|}{ Não conforme } \\
\hline 787 & 7.395 & 475 & 4.654 & 312 & 2.741 \\
\hline $79 \%$ & $79 \%$ & $79 \%$ & $81 \%$ & $79 \%$ & $75 \%$ \\
\hline \multicolumn{6}{|l|}{ Não vistoriado } \\
\hline 22 & 113 & 13 & 106 & 9 & 7 \\
\hline $2 \%$ & $1 \%$ & $2 \%$ & $2 \%$ & $2 \%$ & $0 \%$ \\
\hline
\end{tabular}

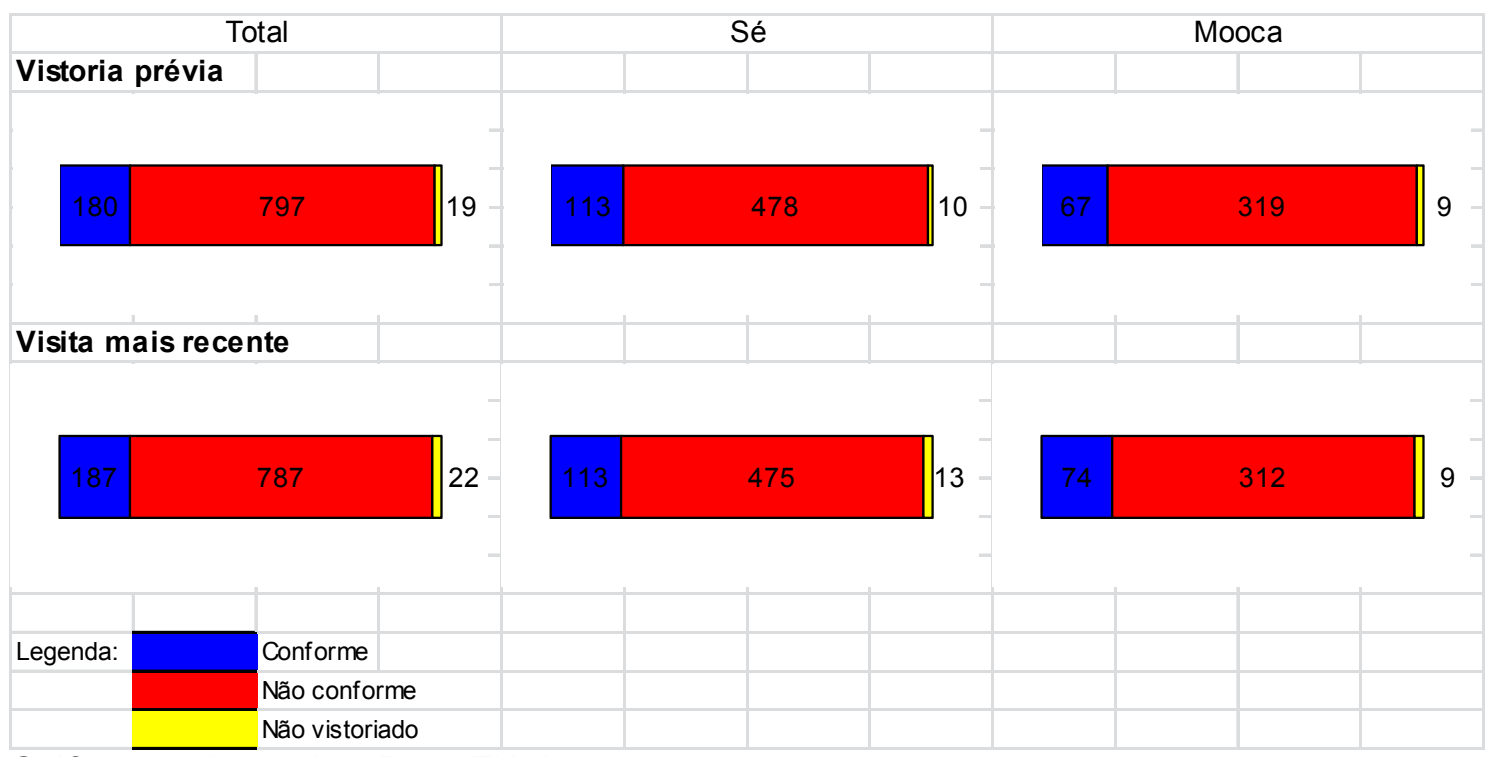

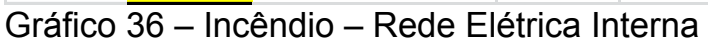


Tabela 51 - Caracterização dos Imóveis - Incêndio - Quadro de Luz

Total de cortiços em funcionamento: 996

\begin{tabular}{|c|c|c|c|c|c|}
\hline \multicolumn{2}{|c|}{ Total } & \multicolumn{2}{|c|}{ Sé } & \multicolumn{2}{|c|}{ Mooca } \\
\hline \multirow{2}{*}{$\begin{array}{c}\text { Imóveis } \\
\text { Vistoria prévia }\end{array}$} & Famílias & Imóveis & Famílias & Imóveis & Famílias \\
\hline & & & & & \\
\hline \multicolumn{6}{|l|}{ Conforme } \\
\hline 544 & 5.388 & 388 & 3.757 & 156 & 1.631 \\
\hline $55 \%$ & $57 \%$ & $65 \%$ & $66 \%$ & $39 \%$ & $45 \%$ \\
\hline \multicolumn{6}{|l|}{ Não conforme } \\
\hline 433 & 3.903 & 203 & 1.897 & 230 & 2.006 \\
\hline $43 \%$ & $42 \%$ & $34 \%$ & $33 \%$ & $58 \%$ & $55 \%$ \\
\hline \multicolumn{6}{|l|}{ Não vistoriado } \\
\hline 19 & 85 & 10 & 78 & 9 & 7 \\
\hline $2 \%$ & $1 \%$ & $2 \%$ & $1 \%$ & $2 \%$ & $0 \%$ \\
\hline & & & & & \\
\hline \multicolumn{6}{|c|}{ Visita mais recente } \\
\hline \multicolumn{6}{|l|}{ Conforme } \\
\hline 550 & 5.437 & 386 & 3.729 & 164 & 1.708 \\
\hline $55 \%$ & $58 \%$ & $64 \%$ & $65 \%$ & $42 \%$ & $47 \%$ \\
\hline \multicolumn{6}{|l|}{ Não conforme } \\
\hline 424 & 3.826 & 202 & 1.897 & 222 & 1.929 \\
\hline $43 \%$ & $41 \%$ & $34 \%$ & $33 \%$ & $56 \%$ & $53 \%$ \\
\hline \multicolumn{6}{|l|}{ Não vistoriado } \\
\hline 22 & 113 & 13 & 106 & 9 & 7 \\
\hline $2 \%$ & $1 \%$ & $2 \%$ & $2 \%$ & $2 \%$ & $0 \%$ \\
\hline
\end{tabular}

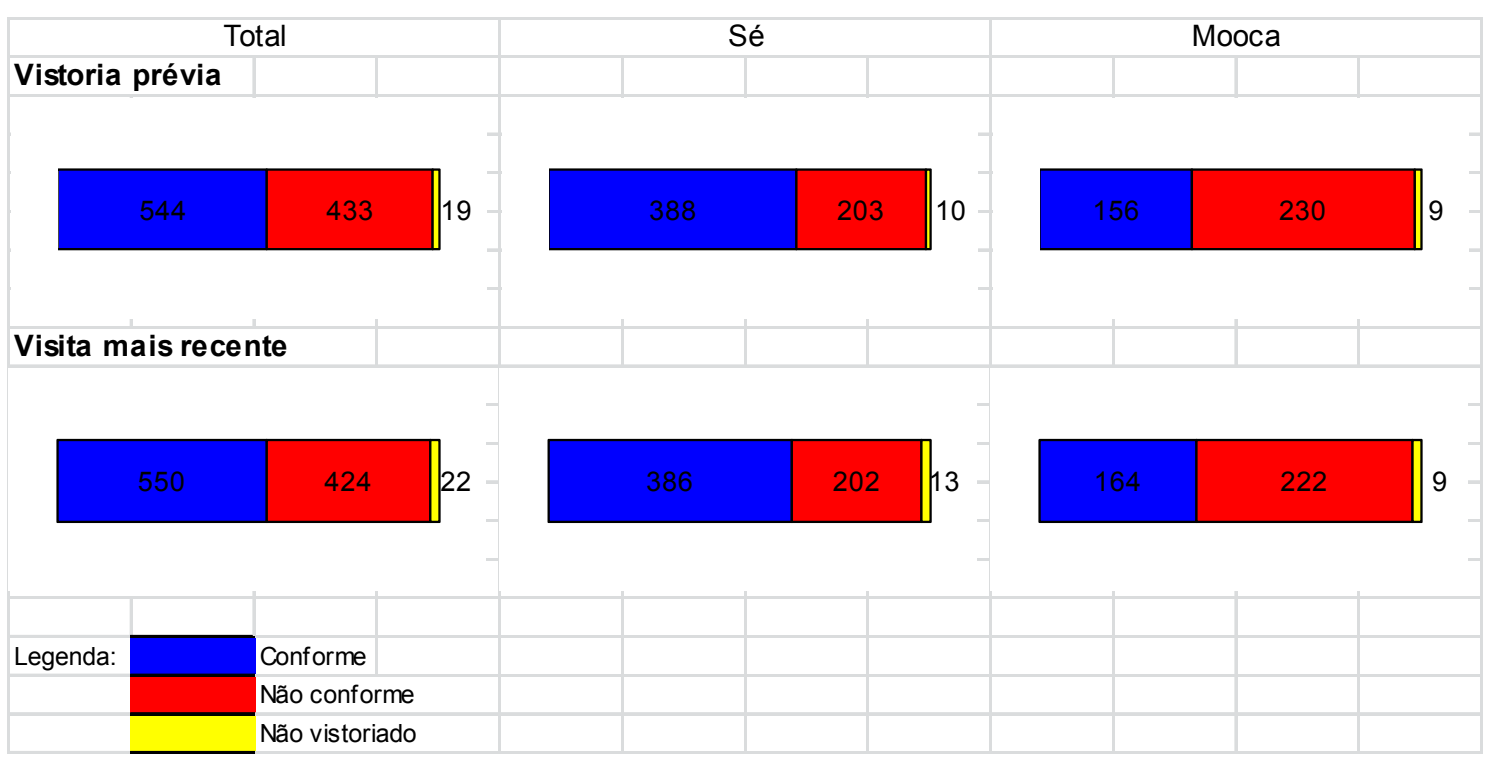

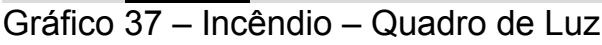


Tabela 52 - Caracterização dos Imóveis - Incêndio - Tomadas

Total de cortiços em funcionamento: 996

\begin{tabular}{|c|c|c|c|c|c|}
\hline \multicolumn{2}{|c|}{ Total } & \multicolumn{2}{|c|}{ Sé } & \multicolumn{2}{|c|}{ Mooca } \\
\hline \multirow{2}{*}{$\begin{array}{c}\text { Imóveis } \\
\text { Vistoria prévia }\end{array}$} & Famílias & Imóveis & Famílias & Imóveis & Famílias \\
\hline & & & & & \\
\hline \multicolumn{6}{|l|}{ Conforme } \\
\hline 135 & 1.224 & 79 & 723 & 56 & 501 \\
\hline $14 \%$ & $13 \%$ & $13 \%$ & $13 \%$ & $14 \%$ & $14 \%$ \\
\hline \multicolumn{6}{|l|}{ Não conforme } \\
\hline 842 & 8.067 & 512 & 4.931 & 330 & 3.136 \\
\hline $85 \%$ & $86 \%$ & $85 \%$ & $86 \%$ & $84 \%$ & $86 \%$ \\
\hline \multicolumn{6}{|l|}{ Não vistoriado } \\
\hline 19 & 85 & 10 & 78 & 9 & 7 \\
\hline $2 \%$ & $1 \%$ & $2 \%$ & $1 \%$ & $2 \%$ & $0 \%$ \\
\hline & & & & & \\
\hline \multicolumn{6}{|c|}{ Visita mais recente } \\
\hline \multicolumn{6}{|l|}{ Conforme } \\
\hline 140 & 1.253 & 79 & 723 & 61 & 530 \\
\hline $14 \%$ & $13 \%$ & $13 \%$ & $13 \%$ & $15 \%$ & $15 \%$ \\
\hline \multicolumn{6}{|l|}{ Não conforme } \\
\hline 834 & 8.010 & 509 & 4.903 & 325 & 3.107 \\
\hline $84 \%$ & $85 \%$ & $85 \%$ & $86 \%$ & $82 \%$ & $85 \%$ \\
\hline \multicolumn{6}{|l|}{ Não vistoriado } \\
\hline 22 & 113 & 13 & 106 & 9 & 7 \\
\hline $2 \%$ & $1 \%$ & $2 \%$ & $2 \%$ & $2 \%$ & $0 \%$ \\
\hline
\end{tabular}

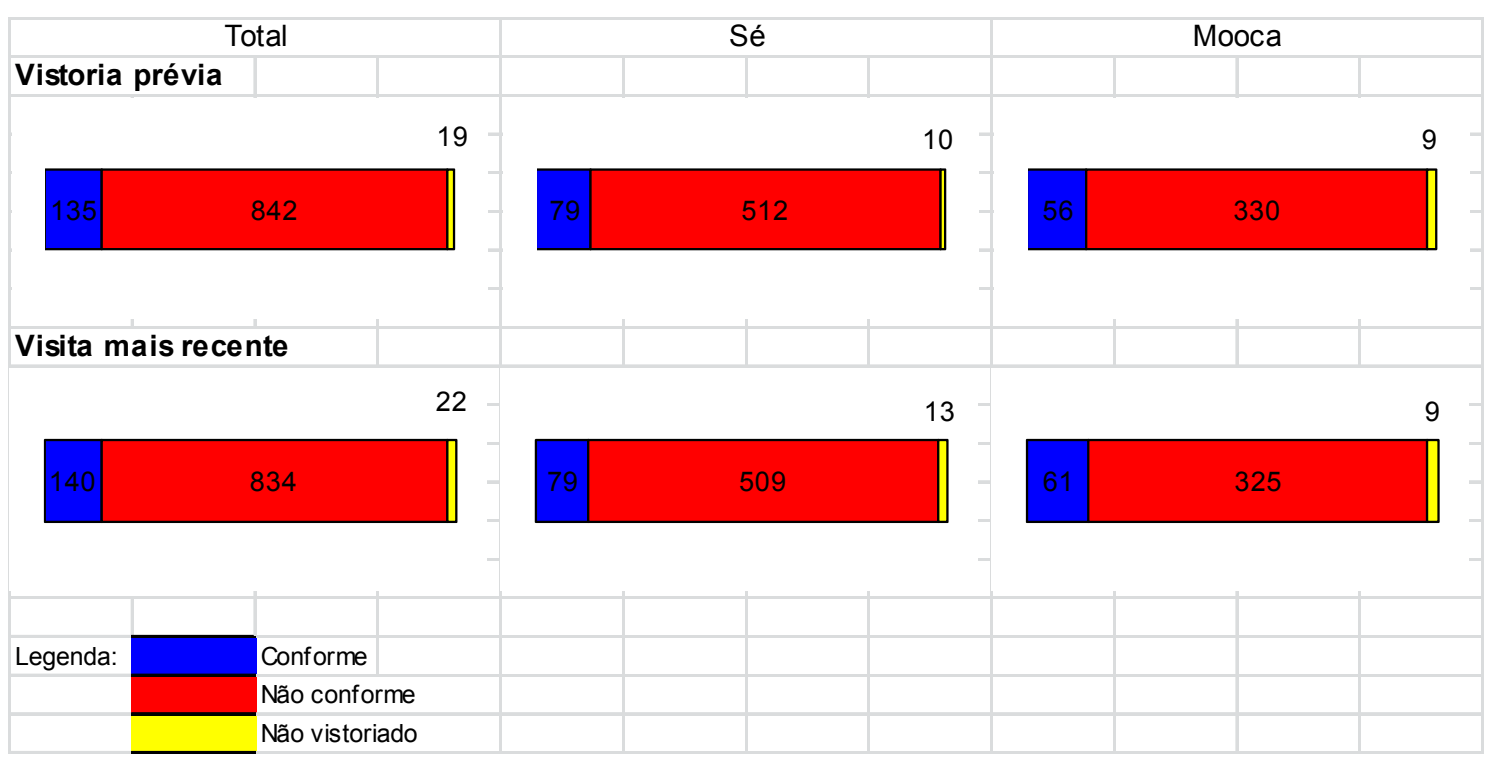

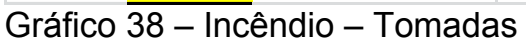

Os dois gráficos abaixo mostram as entradas da Eletropaulo e da Sabesp, e observamos que, do total de cortiços, $12 \%$ e $9 \%$, respectivamente, estão fora dos padrões exigidos pelas companhias (Tabelas 53 e 54, respectivamente). 
Tabela 53 - Caracterização dos Imóveis - Sistemas - Eletropaulo

Total de cortiços em funcionamento: 996

\begin{tabular}{|c|c|c|c|c|c|}
\hline \multicolumn{2}{|c|}{ Total } & \multicolumn{2}{|c|}{ Sé } & \multicolumn{2}{|c|}{ Mooca } \\
\hline \multirow{2}{*}{$\frac{\text { Imóveis }}{\text { Vistoria prévia }}$} & Famílias & Imóveis & Famílias & Imóveis & Famílias \\
\hline & & & & & \\
\hline \multicolumn{6}{|l|}{ Conforme } \\
\hline 857 & 8.163 & 532 & 5.081 & 325 & 3.082 \\
\hline $86 \%$ & $87 \%$ & $89 \%$ & $89 \%$ & $82 \%$ & $85 \%$ \\
\hline \multicolumn{6}{|l|}{ Não conforme } \\
\hline 120 & 1.128 & 59 & 573 & 61 & 555 \\
\hline $12 \%$ & $12 \%$ & $10 \%$ & $10 \%$ & $15 \%$ & $15 \%$ \\
\hline \multicolumn{6}{|l|}{ Não vistoriado } \\
\hline 19 & 85 & 10 & 78 & 9 & 7 \\
\hline $2 \%$ & $1 \%$ & $2 \%$ & $1 \%$ & $2 \%$ & $0 \%$ \\
\hline & & & & & \\
\hline \multicolumn{6}{|c|}{ Visita mais recente } \\
\hline \multicolumn{6}{|l|}{ Conforme } \\
\hline 857 & 8.163 & 529 & 5.053 & 328 & 3.110 \\
\hline $86 \%$ & $87 \%$ & $88 \%$ & $88 \%$ & $83 \%$ & $85 \%$ \\
\hline \multicolumn{6}{|l|}{ Não conforme } \\
\hline 117 & 1.100 & 59 & 573 & 58 & 527 \\
\hline $12 \%$ & $12 \%$ & $10 \%$ & $10 \%$ & $15 \%$ & $14 \%$ \\
\hline \multicolumn{6}{|l|}{ Não vistoriado } \\
\hline 22 & 113 & 13 & 106 & 9 & 7 \\
\hline $2 \%$ & $1 \%$ & $2 \%$ & $2 \%$ & $2 \%$ & $0 \%$ \\
\hline
\end{tabular}

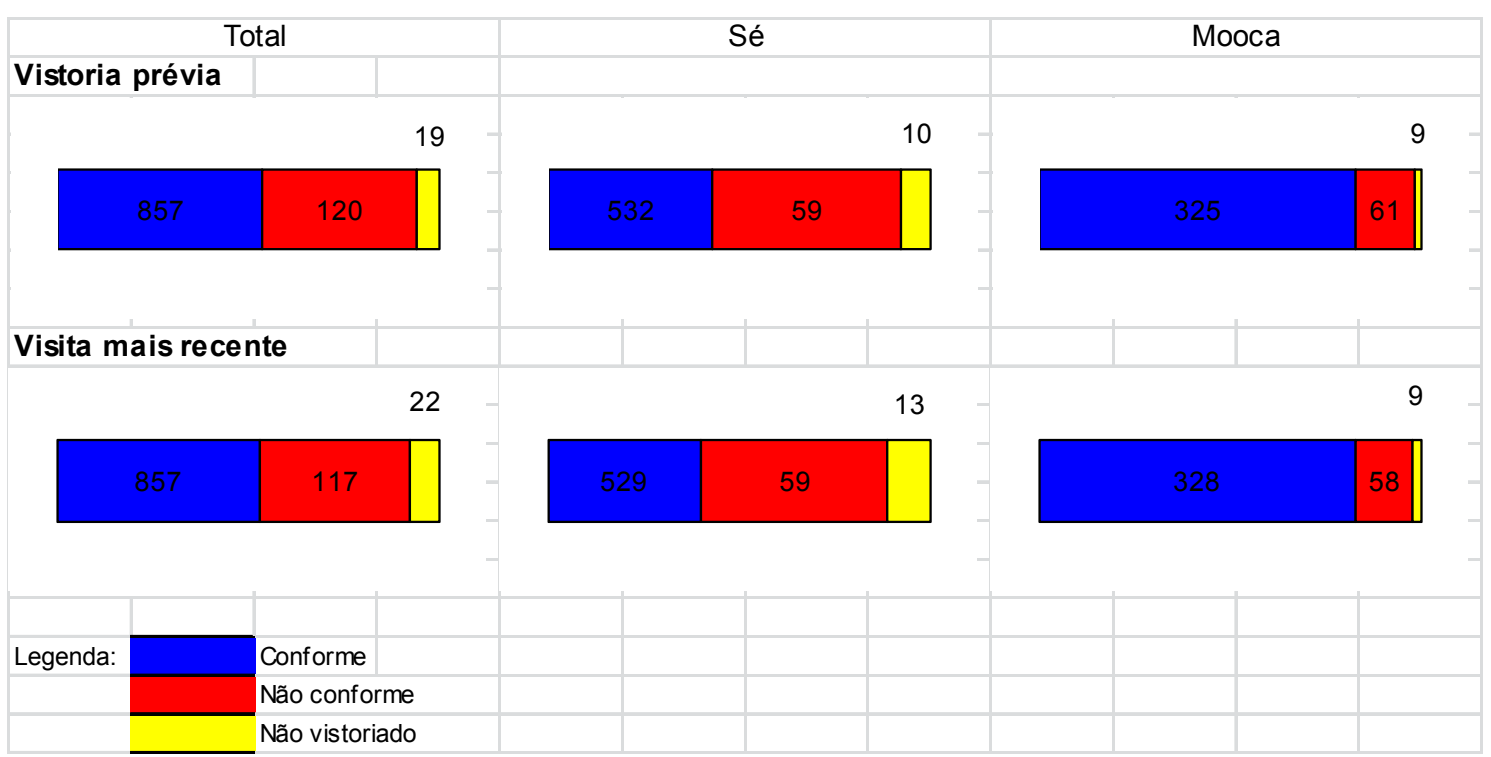

Gráfico $\overline{39-\text { Sistemas - Eletropaulo }}$ 
Tabela 54 - Caracterização dos Imóveis - Sistemas - Sabesp

Total de cortiços em funcionamento: 996

\begin{tabular}{|c|c|c|c|c|c|}
\hline \multicolumn{2}{|c|}{ Total } & \multicolumn{2}{|c|}{ Sé } & \multicolumn{2}{|c|}{ Mooca } \\
\hline Imóveis & Famílias & Imóveis & Famílias & Imóveis & Famílias \\
\hline \multicolumn{6}{|l|}{ Vistoria prévia } \\
\hline \multicolumn{6}{|l|}{ Conforme } \\
\hline 886 & 8.410 & 537 & 5.091 & 349 & 3.319 \\
\hline $89 \%$ & $90 \%$ & $89 \%$ & $89 \%$ & $88 \%$ & $91 \%$ \\
\hline \multicolumn{6}{|l|}{ Não conforme } \\
\hline 91 & 881 & 54 & 563 & 37 & 318 \\
\hline $9 \%$ & $9 \%$ & $9 \%$ & $10 \%$ & $9 \%$ & $9 \%$ \\
\hline \multicolumn{6}{|l|}{ Não vistoriado } \\
\hline 19 & 85 & 10 & 78 & 9 & 7 \\
\hline $2 \%$ & $1 \%$ & $2 \%$ & $1 \%$ & $2 \%$ & $0 \%$ \\
\hline & & & & & \\
\hline \multicolumn{6}{|c|}{ Visita mais recente } \\
\hline \multicolumn{6}{|l|}{ Conforme } \\
\hline 884 & 8.397 & 535 & 5.078 & 349 & 3.319 \\
\hline $89 \%$ & $90 \%$ & $89 \%$ & $89 \%$ & $88 \%$ & $91 \%$ \\
\hline \multicolumn{6}{|l|}{ Não conforme } \\
\hline 90 & 866 & 53 & 548 & 37 & 318 \\
\hline $9 \%$ & $9 \%$ & $9 \%$ & $10 \%$ & $9 \%$ & $9 \%$ \\
\hline \multicolumn{6}{|l|}{ Não vistoriado } \\
\hline 22 & 113 & 13 & 106 & 9 & 7 \\
\hline $2 \%$ & $1 \%$ & $2 \%$ & $2 \%$ & $2 \%$ & $0 \%$ \\
\hline
\end{tabular}

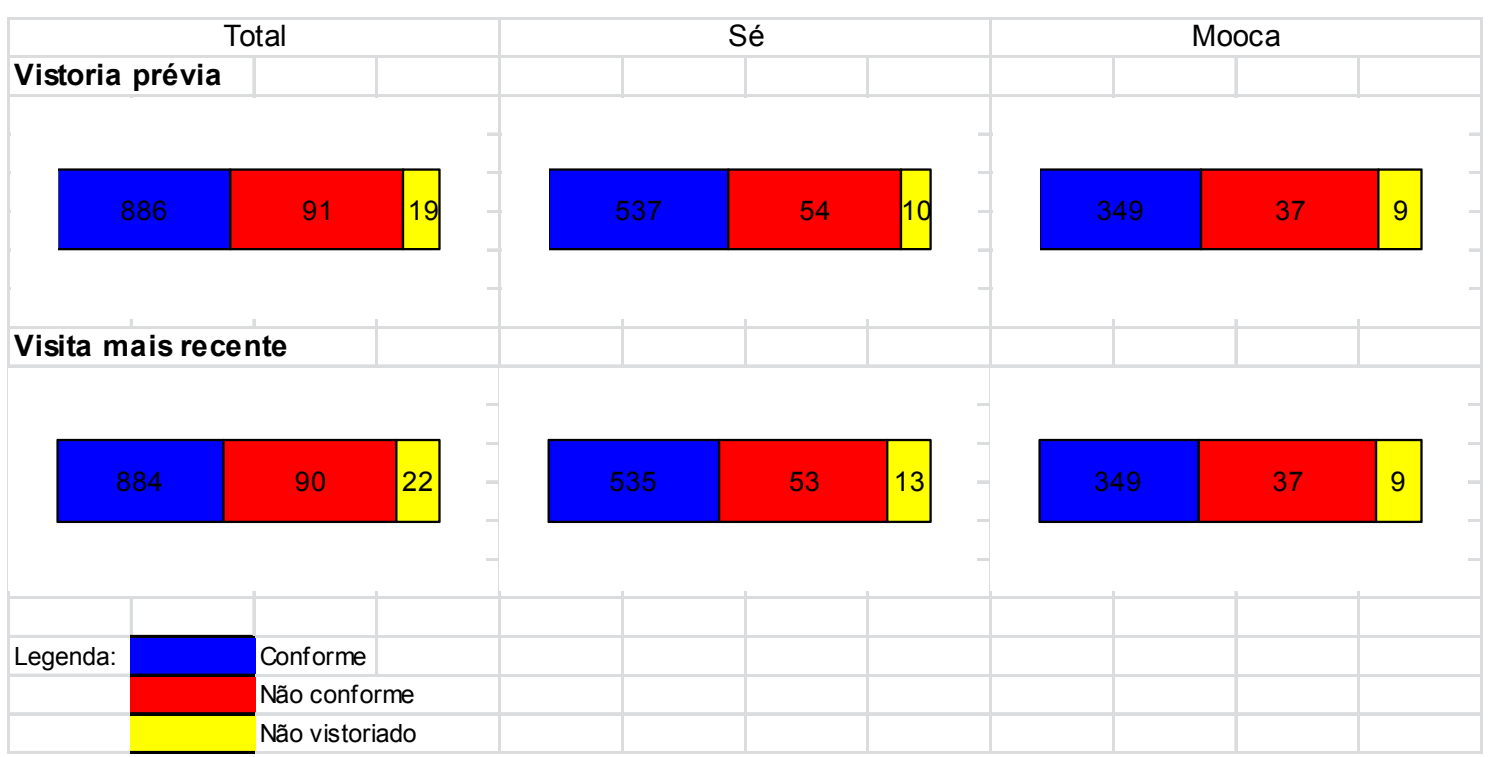

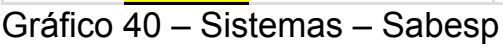




\subsection{Monitoramento das obras}

O índice de priorização dos imóveis encortiçados permite guiar as ações do poder público em suas intervenções, estabelecendo prioridades na seleção de imóveis a receberem os serviços da prefeitura. Esses serviços, por sua vez, configuram-se claramente como atividades de fiscalização, programação de vistorias, emissão de check list de serviços de obras, seu posterior acompanhamento e finalmente o serviço social. Entretanto, o início das obras nos cortiços, com exceção dos imóveis em extrema precariedade, não depende especificamente dessa ordem de acontecimentos.

Como são imóveis particulares, o início da obra é determinado pelo proprietário ou responsável pelo imóvel e não pela priorização do Sistema. Entretanto, do universo de aproximados 1.000 cortiços, dois terços encontram-se em obras. Nesses imóveis, concentram as características mais comuns dos cortiços.

Dos aproximados 700 imóveis em obras, 32\% apresentam um terço dos serviços de obra concluídos; $26 \%$ apresentam dois terços dos serviços de obra concluídos; $35 \%$ estão prestes a terminar as obras e $7 \%$ concluíram suas obras.

No geral, as primeiras reformas não apresentaram complexidades na execução de serviços de obra. No entanto, a execução dos serviços elencados para o saneamento das irregularidades está diretamente ligada às questões de salubridade e de conforto ambiental.

O gráfico a seguir representa um comparativo entre o estado do imóvel encortiçado no momento da vistoria prévia e o estado em que ele se encontra no momento da última visita realizada pela equipe de gestão nos cortiços com obras de adequação. O gráfico é relativo a 755 cortiços em obras. Entretanto, o gráfico representa uma possibilidade de monitoramento das condições de habitabilidade dos cortiços em tempo real, conforme o andamento das visitas de acompanhamento de obra e sua observância na melhoria dos ambientes do cortiço.

Outra informação importante que o gráfico apresenta é a quantidade de cortiços em obra por faixa de priorização: $25 \%$ dos imóveis em obra são cortiços 
com índice de priorização de 0,75 a 0,99 de Pequeno Porte de obra, $49 \%$ dos imóveis em obra são cortiços com índice de 0,50 a 0,75 de obra de Médio Porte; e $22 \%$ dos imóveis em obra são cortiços com índice de 0,25 a 0,50 de obra de Grande Porte.

Tabela 55 - Índices de Adequação das Visitas mais recentes Total de cortiços em obras de adequação e certificados: $\mathbf{7 5 5}$

\begin{tabular}{|c|c|c|c|c|c|}
\hline \multicolumn{2}{|c|}{ Total } & \multicolumn{2}{|c|}{ Sé } & \multicolumn{2}{|c|}{ Mooca } \\
\hline \multirow{2}{*}{$\frac{\text { Imóveis }}{\text { Igual a } 1}$} & Famílias & Imóveis & Famílias & Imóveis & Famílias \\
\hline & & & & & \\
\hline 4 & 26 & 0 & 0 & 4 & 26 \\
\hline $1 \%$ & $0 \%$ & $0 \%$ & $0 \%$ & $1 \%$ & $1 \%$ \\
\hline De 0,75 a 0,99 & & & & & \\
\hline 188 & 1.801 & 102 & 880 & 86 & 921 \\
\hline $25 \%$ & $19 \%$ & $22 \%$ & $15 \%$ & $29 \%$ & $25 \%$ \\
\hline De 0,50 a 0,75 & & & & & \\
\hline 370 & 3.695 & 230 & 2.280 & 140 & 1.415 \\
\hline $49 \%$ & $39 \%$ & $50 \%$ & $40 \%$ & $47 \%$ & $39 \%$ \\
\hline De 0,25 a 0,50 & & & & & \\
\hline 164 & 1.578 & 95 & 1.052 & 69 & 526 \\
\hline $22 \%$ & $14 \%$ & $21 \%$ & $16 \%$ & $23 \%$ & $12 \%$ \\
\hline Menor que 0,25 & & & & & \\
\hline 29 & 251 & 16 & 180 & 13 & 71 \\
\hline $4 \%$ & $2 \%$ & $4 \%$ & $3 \%$ & $4 \%$ & $2 \%$ \\
\hline
\end{tabular}

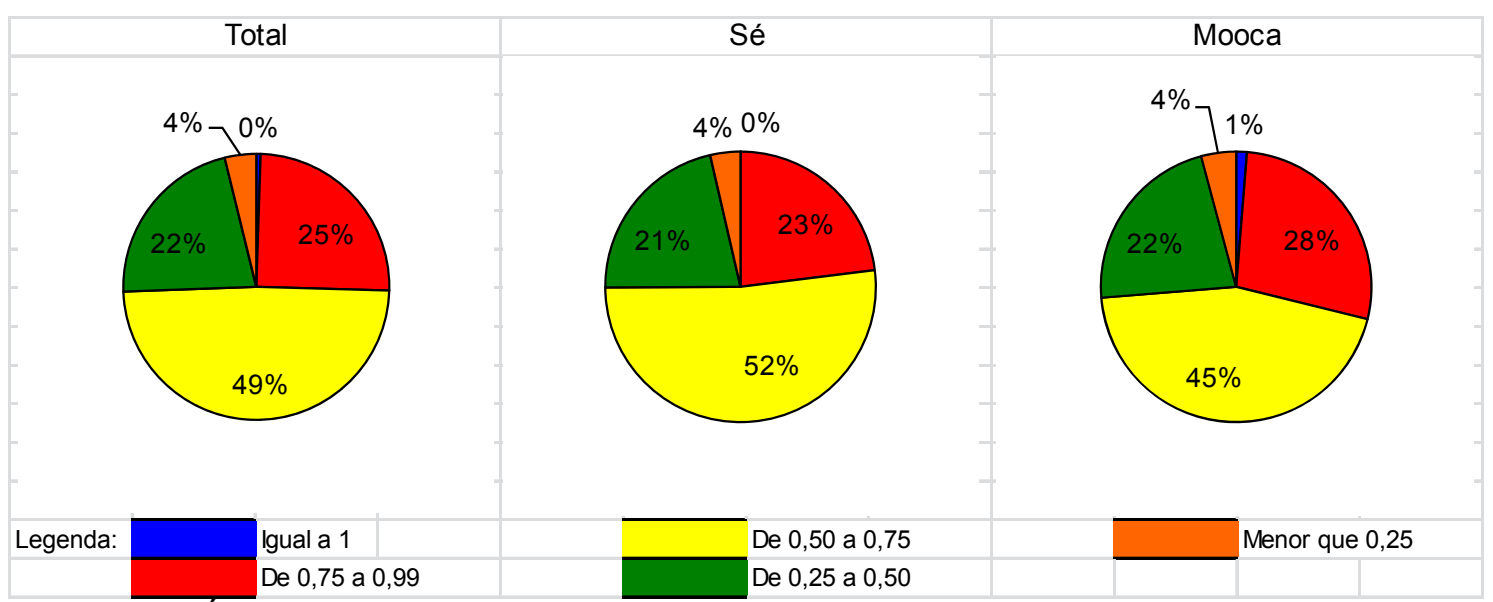

Gráfico 41 - Índices de Adequação das Visitas mais recentes 
Tabela 56 - Progresso dos Índices de Adequação

Total de cortiços em obras de adequação e certificados: $\mathbf{7 5 5}$

\begin{tabular}{|c|c|c|c|c|c|}
\hline \multicolumn{2}{|c|}{ Total } & \multicolumn{2}{|c|}{ Sé } & \multicolumn{2}{|c|}{ Mooca } \\
\hline Imóveis & Famílias & Imóveis & Famílias & Imóveis & Famílias \\
\hline \multicolumn{6}{|c|}{ Progresso igual a $100 \%$} \\
\hline 5 & 28 & 1 & 2 & 4 & 26 \\
\hline $1 \%$ & $0 \%$ & $0 \%$ & $0 \%$ & $1 \%$ & $1 \%$ \\
\hline \multicolumn{6}{|c|}{ Progresso de $75 \%$ a $99 \%$} \\
\hline \multicolumn{2}{|r|}{10} & 0 & 0 & 2 & 10 \\
\hline \multicolumn{2}{|l|}{$0 \%$} & $0 \%$ & $0 \%$ & $1 \%$ & $0 \%$ \\
\hline \multicolumn{2}{|c|}{ Progresso de $50 \%$ a $75 \%$} & & & & \\
\hline \multicolumn{2}{|r|}{91} & 0 & 0 & 6 & 91 \\
\hline \multicolumn{2}{|l|}{$1 \%$} & $0 \%$ & $0 \%$ & $2 \%$ & $2 \%$ \\
\hline \multicolumn{2}{|c|}{ Progresso de $25 \%$ a $50 \%$} & & & & \\
\hline \multicolumn{2}{|r|}{61} & 0 & 0 & 6 & 61 \\
\hline \multicolumn{2}{|l|}{$1 \%$} & $0 \%$ & $0 \%$ & $2 \%$ & $2 \%$ \\
\hline \multicolumn{2}{|c|}{ Progresso de $0 \%$ a $25 \%$} & & & & \\
\hline \multicolumn{2}{|r|}{7.069} & 441 & 4.375 & 288 & 2.694 \\
\hline \multicolumn{2}{|l|}{$97 \%$} & $97 \%$ & $65 \%$ & $96 \%$ & $64 \%$ \\
\hline \multicolumn{6}{|l|}{ Progresso negativo } \\
\hline \multicolumn{2}{|r|}{92} & 1 & 15 & 6 & 77 \\
\hline $1 \%$ & $1 \%$ & $0 \%$ & $0 \%$ & $2 \%$ & $2 \%$ \\
\hline
\end{tabular}

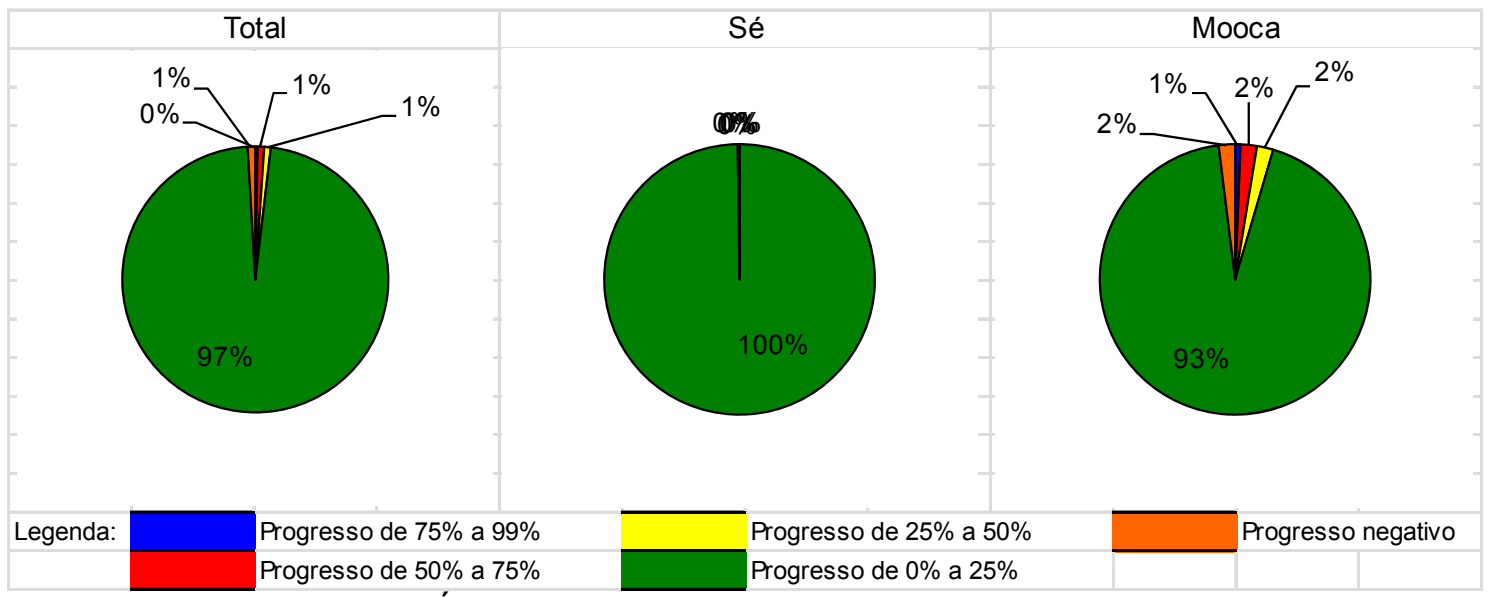

Gráfico 42 - Progresso dos Índices de Adequação 


\section{Considerações finais}

A regulamentação de cortiços na cidade de São Paulo ocorreu desde fins do século XIX ao passo do processo de desenvolvimento da cidade. Entretanto, intervenções substanciais do poder público com foco na população socialmente vulnerável que mora no centro da cidade de São Paulo, intensificaram-se gradualmente a partir dos anos 1990.

Após décadas sem atualizações, é publicada em 1991 a Lei Moura, que estabelece novas regulamentações para cortiços, e com ela a criação da CIRC com a função de promover intervenções concretas em cortiços.

É certo que a cidade contemporânea passa a ser protagonista das políticas públicas, como consequência, entre outros aspectos, da velocidade atual do processo de urbanização decorrente da complexidade cada vez maior da nossa civilização (França, 2009, p 238). Assim como é certa a necessidade de proceder à evolução de nossas regulamentações.

Para tanto, faz-se necessária a análise de resultados obtidos por meio da aplicação da legislação atual.

Dessa maneira, os resultados do Programa de Cortiços podem ser analisados sob três perspectivas: (i) Capacidade gerencial da prefeitura de abordar o problema em larga escala; (ii) Resultados físicos obtidos nos imóveis; e (iii) Mudanças socioeconômicas promovidas na vida dos usuários de cortiços.

O Programa de Cortiços inova especialmente na atividade fiscalizatória, na medida em que acompanha as intimações com um trabalho social de cunho educativo e informativo. Exemplos de fiscalização com amplo volume de resultados são escassos no histórico do poder público municipal.

Quanto à capacidade gerencial, verifica-se que o Programa de Cortiços não utiliza recursos financeiros do poder público municipal, mas fundamentalmente recursos humanos, o que pode facilitar a expansão do Programa para outras localidades do município de São Paulo, uma vez que se trata apenas de gestão de recursos humanos e de gerenciamento de projeto. O Sistema de Informações em ambiente web mostra-se uma ferramenta necessária para o alcance da gestão de 
um volume maior de informações e ações de intervenção em cortiços em todo o território paulistano.

A segunda perspectiva - de análise dos resultados obtidos - refere-se às mudanças físicas das condições de habitabilidade dos imóveis, as quais são previstas na legislação que regula o uso dos imóveis como cortiços. A Lei Moura deveria ser revista, e a partir daí uma série de fatores importantes ao desenvolvimento do Programa terão de ser alterados. O Sistema de Priorização é um deles. Havendo mudanças nas exigências da lei, automaticamente haverá mudanças na prioridade do Programa a partir das alterações dos pesos dos atributos levantados em vistoria.

As exigências da Lei Moura estão sendo obedecidas através de obras de adequação em dois terços dos imóveis classificados como cortiços. No entanto, em alguns casos os resultados físicos podem não ser totalmente satisfatórios pelo fato de a lei ser considerada branda.

No decorrer do Programa, mais precisamente no início do ano 2010, um trabalho de iniciação científica da Escola Politécnica da Universidade de São Paulo realizou medições de temperatura e umidade em cortiços que se encontravam em obras de adequação.

Segundo resultados de análises nas alterações de temperatura e umidade no interior dos cortiços, podemos afirmar que:

[...] não temos evidências estatísticas suficientes que comprovem uma diferença entre as médias de temperatura populacionais ${ }^{44}$, podendo inferir que não houve efeito significativo das regulamentações da Lei Moura. Já no teste de hipótese das médias de umidade relativa do ar rejeitamos a hipótese inicial, aceitando assim a hipótese alternativa, comprovando que a média dos cortiços que não atendem as regulamentações da lei é maior que a média dos cortiços que as atendem." (Teixeira, I, 2010).

44 Refere-se, o autor, à temperatura ambiente medida no interior dos imóveis encortiçados, proveniente da superlotação de pessoas em função das aberturas de aeração dos cômodos. 
De acordo com o estudo de Teixeira (2010):

[...] podemos notar que há somente uma pequena diferença entre os cortiços que estão de acordo com a Lei Moura e os que não estão, apenas 2 pontos percentuais [...] por enquanto podemos afirmar que não há evidências de melhorias com as regulamentações impostas da Lei Moura. Porém, quando tratamos das amostras de umidade relativa do ar, vemos que há uma diferença mais significativa, 12 pontos percentuais. Como a diferença aqui é expressiva e a porcentagem final de medidas dentro da faixa considerada como aceitável é maior nos que estão nos conformes da lei, podemos afirmar que tais regulamentações contribuem para a adequação da umidade relativa do ar local.

Em outros casos, por exemplo, os cortiços classificados como Pequeno e Médio Portes acima das faixas de índice de priorização de 0,6 podem alcançar condições de habitabilidade satisfatórias, considerando que as adequações partem de uma situação menos precária.

O conjunto de inadequações, observadas nos imóveis, é responsável pela elevação da temperatura e da umidade acima do máximo recomendado pelas normas da ABNT. A temperatura máxima recomendada é de $27^{\circ} \mathrm{C}$ em dormitórios e a umidade relativa do ar deverá estar entre $35 \%$ e $65 \%$.

A temperatura e a umidade medidas nesses imóveis apresentaram índice acima da normatização da ABNT em 18\%. Em alguns casos, a medição chegou a $77 \%$ de umidade relativa do ar para os cômodos dos cortiços e a $32^{\circ} \mathrm{C}$ de temperatura.

As primeiras reformas concluídas têm mostrado um bom parâmetro de controle da temperatura e umidade, colocando os cortiços dentro das faixas aceitáveis recomendadas pelas normas, com algumas ressalvas. A eliminação das principais causas de infiltrações e a melhoria na ventilação dos cômodos têm recuperado a salubridade e o conforto ambiental dos imóveis.

A terceira e última perspectiva - de análise dos resultados - refere-se à mudança socioeconômica promovida na vida dos usuários de cortiços que se viram envolvidos com as ações de fiscalização do poder público municipal. 
Aqui destacamos que as obras de adequação em sua grande maioria não incorrem na necessidade de evacuação do imóvel no decorrer da obra. Isso significa que o desadensamento só é realizado quando o cortiço está em desacordo com a alínea "e" do artigo $3^{\circ}$ da Lei Moura, o que ocorre em apenas $12 \%$ dos casos (tabela 35). Nos demais imóveis, os usuários ficam envolvidos com as obras de adequação do cortiço e com as ofertas de unidades habitacionais e do Programa de Cartas de Crédito da CDHU.

Segundo dados da Superintendência de Habitação Popular, no período de 2005 a 2010 foram firmadas aproximadamente 300 cartas de crédito além de 520 unidades habitacionais da CDHU entregues a famílias provenientes de cortiços da área central (Tabela 31).

A estimativa de beneficiados com as obras de adequação nos cortiços é de aproximadamente 7.300 famílias, considerando, inclusive, os imóveis que ainda não concluíram suas obras. Somando as famílias que foram beneficiadas com as demais modalidades de atendimentos como cartas de crédito e unidades habitacionais observamos um total de aproximadamente 9 mil atendimentos.

É importante destacar aqui que a sustentabilidade urbana decorre do objetivo central da ação implementada pelo poder público municipal - ou Objetivo Superior que é propiciar às famílias de baixa renda o acesso à moradia digna na área central da cidade de São Paulo.

O artigo $6^{\circ}$ da Constituição Federal, o Estatuto da Cidade e o artigo 79 do Plano Diretor Estratégico (Lei Municipal $n^{\circ} 13.430$, de 2002) definem moradia digna como aquela que:

[...] garante ao morador a segurança na posse e dispõe de instalações sanitárias adequadas, com condições de habitabilidade atendidas por serviços públicos essenciais - abastecimento de água potável, esgotamento sanitário, energia elétrica, iluminação pública, coleta de lixo, pavimentação e transporte coletivo, além do acesso aos equipamentos sociais básicos. 
Os cortiços que estão de acordo com a Lei Moura atendem ao conceito de moradia digna. A segurança da posse é dada pela Lei do Inquilinato, bastando para isso, única e exclusivamente, o exercício de cidadania ${ }^{45}$ de seus usuários. Quanto aos serviços públicos essenciais e acesso a equipamentos sociais básicos, os cortiços, devido à sua localização central, se encontram amplamente servidos.

Resta, portanto, aprimorar as exigências da Lei Moura, elevando as condições de habitabilidade desses imóveis. A revisão prevista na minuta do Plano Municipal de Habitação poderá direcionar os cômodos de cortiços às condições de habitabilidade desejadas pelo poder público e principalmente por seus usuários.

Quanto às intervenções em cortiços, ainda que incipientes, os resultados das primeiras reformas oferecem subsídios para promover melhorias na atual legislação que rege as reformas nos imóveis. As irregularidades constatadas em cômodos de cortiços indicam que muitos deles estão extremamente aquém das exigências de habitabilidade, assim como há outros cujas condições as superam. À medida que a atividade de recuperação dos cortiços vai se aperfeiçoando, a lei vigente poderá também ser aperfeiçoada, repercutindo na ampliação das obras e na melhoria de toda a operação.

Quanto ao aperfeiçoamento da legislação atual, o quadro a seguir mostra um breve resumo de dados levantados no Programa de Cortiços para cálculo de novos parâmetros de qualidade.

Tabela 57 - Quadro de subsídios para alteração da Lei Moura

\begin{tabular}{|l|r|}
\hline Total de área construída $\left(\mathrm{m}^{2}\right)$ & 215.012 \\
\hline Total de pessoas & 15.710 \\
\hline Área construída média de cortiços $\left(\mathrm{m}^{2}\right)$ & 215,9 \\
\hline Quantidade de cortiços & 996 \\
\hline Pessoas/cortiço & 15,8 \\
\hline Média de pessoas por cômodo & 1,7 \\
\hline Quantidade de pessoas a cada 3 cômodos & 5,03 \\
\hline Média de $\mathrm{m}^{2}$ de área construída para cada pessoa & 13,69 \\
\hline Total de familias/cômodos & 9.376 \\
\hline Familias (cômodo)/cortiço & 9,4 \\
\hline
\end{tabular}

\footnotetext{
${ }^{45}$ Neste caso, entende-se como exercício de cidadania a disposição dos cidadãos em denunciarem questões contratuais previstas na lei do inquilinato.
} 
Ao analisar os dados de cortiços vemos uma média de 13,69 $\mathrm{m}^{2}$ para cada pessoa, muito próxima da exigência de $15 \mathrm{~m}^{2}$ em usos residenciais segundo o Código de Obras do Município de São Paulo. Esta medida poderia alterar o adensamento atual em de cortiços que é 2 pessoas a cada $8 \mathrm{~m}^{2}$ previsto na lei.

Observamos 1,68 pessoas por cômodo, ao somar a quantidade de pessoas a cada 3 cômodos chegamos a 5,03, próximo a média de uma composição familiar. Esta medida poderia alterar a relação de 20 pessoas para cada banheiro, pia e tanque exigidos na lei atual.

Além da adição desses parâmetros, podem ser consideradas as recomendações de segurança indicadas pelo CONTRU como por exemplo, a colocação obrigatória de extintores e a retirada de botijão do gás de cozinha do interior dos cômodos. Da mesma forma, o acondicionamento correto de materiais inflamáveis como papéis, plásticos e tecidos sintéticos em locais arejados e de maneira a não causar obstrução de passagens que possam ser utilizadas como rotas de fuga. Tais medidas, acompanhadas de um trabalho social de cunho educativo e informativo podem promover inclusive a constituição de brigadas de incêndio nos imóveis.

Devemos observar, entretanto, que os dados analisados referem-se a cortiços existentes no centro da cidade de São Paulo. Dessa forma, os cortiços da periferia da cidade, caso não apresentem características semelhantes, poderão passar por um processo semelhante de pesquisa e apreciação como os cortiços do centro.

O quadro a seguir apresenta uma proposta de alteração nos itens do artigo $3^{\circ}$ da Lei Moura tornando os parâmetros mínimos de qualidade mais exigentes.

Vejamos: 
Tabela 58 - Proposta de alteração da Lei Moura

\begin{tabular}{|c|c|c|}
\hline & Lei Moura, 10.928 de 1991 & Proposta de alteração \\
\hline Artigo $3^{\circ}$ & $\begin{array}{l}\text { Independentemente de outras normas aplicáveis, } \\
\text { consideram-se as condições mínimas de } \\
\text { habitação, para os fins desta lei, as seguintes: }\end{array}$ & \\
\hline a & $\begin{array}{l}\text { Segurança do imóvel no tocante à sua instalação } \\
\text { elétrica e à sua estrutura, comprovadas através do } \\
\text { laudo expedido pelo órgão público competente, } \\
\text { renovado a cada dois anos; }\end{array}$ & $\begin{array}{l}\text { Segurança do imóvel no tocante à sua instalação } \\
\text { elétrica e à sua estrutura, comprovadas através } \\
\text { do laudo expedido pelo órgão público competente } \\
\text { ou entidades reconhecidas ou de particiulares } \\
\text { sujeita a fiscalização, renovado a cada dois anos. }\end{array}$ \\
\hline $\mathrm{b}$ & $\begin{array}{l}\text { lluminação mínima por cômodo 1/7 (um sétimo) da } \\
\text { área de piso; }\end{array}$ & Não altera pois equivale ao código de obras. \\
\hline C & $\begin{array}{l}\text { Ventilação mínima por cômodo de metade da área } \\
\text { de iluminação; }\end{array}$ & Não altera pois equivale ao código de obras. \\
\hline \multirow[t]{2}{*}{ d } & \multirow[t]{2}{*}{$\begin{array}{l}\text { Área mínima do cômodo ou divisão não inferior a } 5 \\
\text { m2 (cinco metros quadrados), com sua menor } \\
\text { dimensão não inferior a } 2 \text { ( dois ) metros; }\end{array}$} & Mínimo $15 \mathrm{~m}^{2}$. \\
\hline & & Menor dimensão - 3m. \\
\hline e & $\begin{array}{l}\text { Adensamento máximo de } 2 \text { ( duas ) pessoas por } \\
8 \mathrm{~m} 2 \text { ( oito metros quadrados), considerando toda } \\
\text { a área construída da edificação, vedado o } \\
\text { revezamento; }\end{array}$ & Igualar ao código de obras - 15 m2 /pessoa. \\
\hline f & $\begin{array}{l}\text { Banheiro revestido de piso lavável e de barra } \\
\text { impermeável até } 2 \text { ( dois ) metros de altura; }\end{array}$ & Não altera. \\
\hline$g$ & $\begin{array}{l}\text { Os banheiros serão dotados, pelo menos, de vaso } \\
\text { sanitário, lavatório e chuveiro em funcionamento, } \\
\text { compartimentos, sempre que possível, de forma } \\
\text { independente, com abertura para o exterior; }\end{array}$ & $\begin{array}{l}\text { Banheiro com pelo menos } 1 \text { vaso sanitário, } 1 \\
\text { lavatório, e } 1 \text { chuveiro - obrigatorio abertura } \\
\text { externa para ventilação. }\end{array}$ \\
\hline $\mathrm{h}$ & $\begin{array}{l}\text { Haverá no mínimo } 1 \text { ( um ) tanque, } 1 \text { ( uma ) pia e } 1 \\
\text { ( um ) banheiro para cada grupo de } 20 \text { ( vinte ) } \\
\text { moradores; }\end{array}$ & $\begin{array}{l}1 \text { tanque, } 1 \text { pia, } 1 \text { banheiro para um grupo de } 3 \\
\text { comodos ou } 5 \text { pessoas prevalecendo o maior } \\
\text { numero de equipamentos entre os dois. }\end{array}$ \\
\hline $\mathrm{i}$ & $\begin{array}{l}\text { O pé direito será de, no mínimo, 2,30m ( dois } \\
\text { metros e trinta centímetros ); }\end{array}$ & $\begin{array}{l}\text { Igualar ao código de obras - pé direito de } 2,5 \mathrm{~m} \\
\text { de altura. }\end{array}$ \\
\hline j & $\begin{array}{l}\text { As escadas e corredores de circulação terão, pelo } \\
\text { menos, } 80 \text { ( oitenta ) centímetros de largura. }\end{array}$ & Não altera. \\
\hline & & Bujão de gás obrigatorio para fora do cômodo. \\
\hline & & Obrigatorio fiação em canaleta. \\
\hline & & $\begin{array}{l}\text { Proibida disposição de material inflamavel nas } \\
\text { áreas comuns do imovel. }\end{array}$ \\
\hline & & $\begin{array}{l}\text { Proibido divisoria de madeira, podendo ser } \\
\text { alvenaria, gesso acartonado ou simular. }\end{array}$ \\
\hline & & Obrigatorio apresentação de extitor de incendio. \\
\hline
\end{tabular}

Após 14 anos de sua publicação, a Lei Moura é utilizada na cidade de São Paulo e após 6 anos de sua aplicação é possível reunir dados provenientes da fiscalização e de vistorias realizadas em cortiços na área central da cidade, os quais 
se apresentam como insumos importantes ao estudo de revisão das condições de habitabilidade exigidas pela lei atual.

A cidade continua a se desenvolver por expansão territorial ou por verticalização na utilização de seu potencial construtivo. A cidade continua a criar sistemas de regulação ou controle que visam à manutenção ou melhoria da qualidade urbana. A cidade se renova e se moderniza em seus aspectos tecnológicos e comportamentais e a legislação sempre acompanhou a ordem social e os bons costumes em sua evolução de forma a garantir a qualidade de vida de todas as camadas sociais da população.

Novas pesquisas sobre cortiços, vinculados ao aspecto urbano e social, como (i) Estudos de pós uso em imóveis adequados à Lei Moura, (ii) Pesquisas socioeconômicas de novas demandas populacionais de baixa renda em centros urbanos, (iii) Estudos sobre o reflexo das variações do mercado imobiliário nesses imóveis encortiçados e (iv) Estudos de cortiços na periferia da cidade serão de fundamental importância.

Da mesma forma, pesquisas vinculadas ao aspecto construtivo como (v) Estudos de aerações específicas para ambientes residenciais em superlotação, (vi) Estudo de partículas em suspensão no ambiente interno dos cortiços e (vii) Análise de emissões de gás carbônico por superlotação de pessoas, podem colaborar para a expansão do conhecimento a cerca deste fenômeno de ocupação típico de centros urbanos e típico de São Paulo.

Esta dissertação é uma contribuição para tal. 


\section{REFERÊNCIAS BIBLIOGRÁFICAS}

ALFONSIN, B.; FERNANDES E. Direito urbanístico. Estudos brasileiros e internacionais. $1^{\text {a }}$ edição. Belo Horizonte. Del Rey, 2006. 392p.

BLOCH, L. L. e BOTELHO, M. H. C. Código de Obras e Edificações do Município de São Paulo: comentado e criticado. São Paulo, Pini, 1993.

BONDUKI, N. Origens da habitação social no Brasil. O caso de São Paulo. Tese de doutorado. Faculdade de arquitetura e urbanismo. Universidade de São Paulo, 1994.

BRAMLEY, G. Social sustainability and urban form: evidence from five British cities. Environment and Planning, volume 41, pp. 2125 - 2142. 2009.

BRANDÃO, Maria Claudia da Costa. A moradia de baixa renda e o centro urbano: qualificação ou degradação? O caso dos cortiços nas Áreas Centrais de São Paulo. São Paulo, 2003. Dissertação de Mestrado, Instituto de Pesquisas Tecnológicas do Estado de São Paulo.

BRASIL. Lei $n^{\circ} 4.591$ de 16 de dezembro de 1964. Dispõe sobre o condomínio em edificações e as incorporações imobiliárias.

BURDETT, R.; SUDJIC, D. The Endless City. First published. New York. Phaidon Press. 2007. 510p.

COMPANHIA DE DESENVOLVIMENTO HABITACIONAL E URBANO - CDHU. Programa de Atuação em Cortiços. São Paulo, 1997.

FIPE - FUNDAÇÃO INSTITUTO DE PESQUISA ECONÔMICA. Diagnóstico e plano de ações fase: versão final. São Paulo, 1997, v.1-2-3.

FIPE - FUNDAÇÃO INSTITUTO DE PESQUISA ECONÔMICA. Estudo das favelas e cortiços da cidade de São Paulo: relatório final. São Paulo, 1994, v.1-2 
FRANÇA, E. Favelas em São Paulo (1980-2008) Das propostas de desfavelamento aos projetos de urbanização. A experiência do Programa Guarapiranga. Tese de doutorado. Universidade Presbiteriana. Mackenzie. 2009.

FUNDAÇÃO SISTEMA ESTADUAL DE ANÁLISE DE DADOS. CDHU-SGPAC. Pesquisa socioeconômica SBI-PAC. São Paulo 2002.

FUNDAÇÃO SISTEMA ESTADUAL DE ANÁLISE DE DADOS. Relatório I Estimativa de necessidades habitacionais no estado de São Paulo, julho de 2009, 79 p. Prestação de serviços para produção de insumos para elaboração do Plano Estadual de Habitação de Interesse Social do Estado de São Paulo (PEHIS).

COSTA, K.P.; FRANÇA, E.; LÓPEZ, A.;. (orgs.). Cortiços - A experiência de São Paulo. $1^{a}$ edição. São Paulo: Superintendência de Habitação Popular, 2010. v. 1, $144 \mathrm{p}$.

PARR. S.F. Relatório de desenvolvimento humano 2002. Aprofundar a democracia num mundo fragmentado. Lisboa, PNUD, 2002, 277p.

PICCINI, Andrea. Cortiços e reestruturação do centro urbano de São Paulo, Habitação e instrumentos urbanísticos. São Paulo, 1996, Tese de Doutorado, Escola Politécnica, Universidade de São Paulo.

RIGOUT, F. (Org). e equipe de HABI. Quadro lógico do Programa de Cortiços. Documento de consultoria. São Paulo, Plan Políticas Públicas, 2008.

ROTTMANN, E. Programa Morar no Centro. São Paulo - SP. Estudo do mercado de locação residencial na área central. Contacto Consultores, dezembro de 2004, 194 p.

SIMÕES JUNIOR. J. G. O setor de obras públicas e as origens do urbanismo na cidade de São Paulo. São Paulo. 1990. Dissertação de mestrado, Escola de administração de empresas de São Paulo, Fundação Getúlio Vargas.

TCRP. (1998). The costs of sprawl revisited. Report 39.

TEIXEIRA, I.M. Lei Moura - Uma alternativa insuficiente para a adequação sanitária de habitações populares no centro da cidade de São Paulo. 2010. Iniciação científica. Escola Politécnica da Universidade de São Paulo. 
TOLEDO, B. L. Prestes Maia e as origens do urbanismo moderno em São Paulo. São Paulo. Empresa das Artes, 1996.

WERNA, E. et al. Pluralismo na Habitação. 1ª edição. São Paulo. Annablume, 2001. 300p.

YIFTACHEL, O. (1993). Urban social sustainability: the planning of an Australian city. Cites 10, pp. 139-157. 


\section{BIBLIOGRAFIA COMPLEMENTAR}

ABIKO, A. K., CAMPANÁRIO, V.A. M., COMARÚ, F. A. Cortiços na cidade de São Paulo: características e possibilidades de intervenção.: In: Encontro Nacional de Tecnologia do Ambiente Construído, 2., São Paulo, 1993. Anais. São Paulo, ANTAC, 1993.

BERNSTEIN K.T., GALEA S., AHERN J., et al. The built environment and alcohol consumption in urban neighborhoods. Drug and Alcohol Dependence 91, 244-252. disponível em: www.elsevier.com/locate/drugalcdep, 2007.

BLAY, E. A. Eu não tenho onde morar: vilas operárias na cidade de São Paulo. São Paulo, Nobel, 1985.

BRASIL. Lei $n^{\circ}$ 8.245, de 18 de outubro de 1991. Dispõe sobre as locações dos imóveis urbanos e procedimentos a elas pertinentes.

CARPINTÉRO, M. V. T. A construção de um sonho: os engenheiros-arquitetos e a formulação da política habitacional no Brasil, Campinas SP, Ed. Unicamp, 1997.

Código de Posturas do Município de São Paulo. Imprensa Oficial do Estado de São Paulo, 1886.

Collecção das Leis e Decretos do Estado de São Paulo de 1894 Tomo IV. Imprensa Oficial do Estado de São Paulo. Typographia do Diário Official. Sâo Paulo. 1918.

Collecção de Leis e Posturas Municipaes Promulgadas pela Assembléa Legislativa Provincial de São Paulo no Anno de 1875. Imprensa Oficial do Estado de São Paulo. Typographia do Diário. 1875.

COMARÚ, F. de A. Intervenção Habitacional em cortiços na cidade de São Paulo: O mutirão Celso Garcia. São Paulo, 1998, Dissertação de Mestrado, Escola Politécnica, Universidade de São Paulo.

COMPANHIA DE DESENVOLVIMENTO HABITACIONAL E URBANO - CDHU. Identificação da Área e Caracterização de Imóveis Encortiçados - Área Luz/Cantareira, São Paulo, Escritório Pleno, 1997. 
FRANÇA, E, ESCRIBANO, A, COELHO, E. C. R..Habisp Mapeando a Habitação na Cidade de São Paulo. $1^{a}$ edição. SÃO PAULO: Arvato do Brasil Gráfica, 2008. v. 2000. $119 \mathrm{p}$.

FRANÇA, E., HERLING,T. Habitação de interesse social em São Paulo: Desafios e Novos Instrumentos de Gestão. Prefeitura do Município de São Paulo, Cities Alliance - São Paulo, Janeiro Projetos Urbanos, 2008.

HIRANOA T., KATOA S., MURAKAMIB S., et al. A study on a porous residential building model in hot and humid regions: Part 1 -the natural ventilation performance and the cooling load reduction effect of the building model. Building and Environment 41 21-32. Disponível em:www.elsevier.com/locate/buildenv, 2006.

KARIMA S.A., ANWARB K.S., KHANC M.A.H., et al. Socio-demographic characteristics of children infested with scabies in densely populated communities of residential madrashas (Islamic education institute) in Dhaka, Bangladesh. Public Health 121, 923-934. Disponível em: www.elsevierhealth.com/journals/pubh, 2007.

KOHARA, L. T. Relação entre as condição das moradias e o desempenho escolar: estudo com crianças residentes em cortiços. São Paulo, 2009. Tese de Doutorado. Faculdade de Arquitetura da Universidade de São Paulo.

KOWARICK, L. e ANT, C. Cem anos de promiscuidade: o cortiço na cidade de São Paulo in Kowarick L. (org.) As lutas sociais e a cidade: São Paulo, passado e presente. São Paulo, Paz e Terra, 1988.

LARA, A.M.F. et al. Inspeção Predial: Check up predial: Guia da boa manutenção. 1. ed. [São Paulo]. Livraria e Editora Universitária de Direito. 2005. 247p.

MONTEIRO, F. D. R. Locação em debate. $1^{\text {a }}$ edição. Rio de Janeiro. Forense, 1999. 492p.

Padrão Municipal de S. Paulo. Imprensa Oficial do Estado de São Paulo, 1886.

PREFEITURA MUNICIPAL DE SÃO PAULO, Secretaria Municipal do Planejamento SEMPLA. Cortiços em São Paulo, frente e verso. São Paulo, 1986. 
RIBEIRO, L. C. de Q. Dos cortiços aos condomínios fechados: as formas de produção da moradia na cidade do Rio de Janeiro. Rio de Janeiro, Civilização Brasileira, 1997.SANDRONI, P. Dicionário de Administração e Finanças. São Paulo, Best Seller, 1996.

SANTAMOURIS M., PAVLOU K., SYNNEFA A., et al. Recent progress on passive cooling techniques Advanced technological developments to improve survivability levels in low-income households. Elsevier B.V. All rights reserved. Disponível em: www.sciencedirect.com, 2007.

SÃO PAULO (MUNICÍPIO). Collecção de Leis e Posturas Municipaes. Promulgadas pela Assembléa Legislativa Provincial de São Paulo. 1875.

SÃO PAULO (MUNICÍPIO). Conselho Municipal de Habitação. Aprova o Programa de Cortiços - Reabilitação da Moradia Coletiva. Resolução CMH n ${ }^{\circ} 15$ de 07 de dezembro de 2004. Programa de Cortiços, São Paulo, 07 de dezembro de 2004.

SÃO PAULO (MUNICÍPIO) Decreto $n^{\circ}$ 44.667, de 26 de ABRIL de 2004 Regulamenta as disposições da Lei $n^{\circ} 13.430$, de 13 de setembro de 2002, que institui o Plano Diretor Estratégico, relativas às Zonas Especiais de Interesse Social e aos respectivos Planos de Urbanização, e dispõe sobre normas específicas para a produção de Empreendimentos de Habitação de Interesse Social, Habitação de Interesse Social e Habitação do Mercado Popular. Publicado na Secretaria do Governo Municipal, em 26 de abril de 2004.

SÃO PAULO (MUNICÍPIO). Decreto $\mathrm{n}^{\circ}$ 33.189, de 17 de Maio de 1993. Regulamenta a lei $n^{\circ} 10.928$, de 8 de janeiro de 1991, revoga o decreto $n^{\circ} 30.731$, de 12 de dezembro de 1991, e dá outras providências.

SÃO PAULO (MUNICÍPIO). Lei $n^{\circ}$ 10.928, de 8 de janeiro de 1991. Regulamenta o inciso II do artigo 148 combinado com o inciso $V$ do artigo 149 da. L.O.M. dispõe sobre as condições de habitação dos cortiços, e dá outras providências. Publicada na Secretaria do Governo Municipal, em 8 de janeiro de 1991.

SÃO PAULO (Município). Lei $n^{\circ} 11.228$, de 25 de junho de 1992. Dispõe sobre as regras gerais e específicas a serem obedecidas no projeto, licenciamento, execução, manutenção e utilização de obras e edificações, dentro dos limites dos imóveis revoga a Lei $n^{\circ} 8.266$, de 20 de junho de 1975, com as alterações adotadas por leis posteriores, e dá outras providências. 
SÃO PAULO (MUNICÍPIO). Lei $\mathrm{n}^{\circ} 13.430$ de 13 de setembro de 2002. Da conceituação, finalidade, abrangência e objetivos do Plano Diretor de São Paulo.

SÃO PAULO (MUNICÍPIO). Lei $n^{\circ} 14.917$ de 7 de maio de 2009. Dispõe sobre a concessão urbanística no Município de São Paulo.

SÃO PAULO (MUNICÍPIO). Lei $n^{\circ} 14.918$ de 7 de maio de 2009. Autoriza o Executivo a aplicar a concessão urbanística na área da Nova Luz.

SÃO PAULO (MUNICÍPIO). Relatório da Commissão de Exame e Inspecção das Habitações Operárias e Cortiços no Distrito de Santa Ephigenia. 1893.

SIMÕES JÚNIOR, J. G. Cortiços em São Paulo: o problema e suas alternativas. Revista Pólis, $n^{\circ}$ 2, 1991.

VÉRAS, M. P. B. Cortiços em São Paulo: velhas e novas formas da pobreza urbana e da segregação social in Bógus L. M. M. e Wanderley L. E. W. (org.) A luta pela cidade em São Paulo. São Paulo, Cortez, 1992.

. O bairro do Brás em São Paulo: um século de transformações no espaço

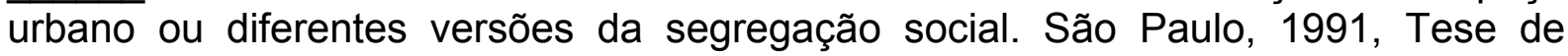
Doutorado, Pontifícia Universidade Católica.

VILAÇA, F. O que o cidadão precisa saber sobre habitação. São Paulo, Global, 1986.

WEST B.N., EMMITT S.. Functional design? An analysis of new speculative house plans in the UK. Design Studies 25 (2004) 275-299. Disponível em:< www.elsevier.com/locate/destud>.

WHITLEYA R., Prince M. Fear of crime, mobility and mental health in inner-city. London, UK. Social Science \& Medicine 61 1678-1688. Disponível em: www.elsevier.com/locate/socscimed, 2005.

ZMITROWICZ, W. As obras públicas de engenharia e a sua função na estruturação da cidade de São Paulo. São Paulo, 1997, Tese (Doutorado), Escola Politécnica, Universidade de São Paulo. 
ANEXO A - Lei Moura.

\section{LEI N010.928 DE 8 DE JANEIRO DE 1991}

(Projeto de Lei $n^{\circ} 504 / 89$, do Vereador Luiz Carlos Moura)

Regulamenta o inciso II do artigo 148 combinado com o inciso $V$ do artigo 149 da. L.O.M. dispõe sobre as condições de habitação dos cortiços, e dá outras providências.

LUIZA ERUNDINA DE SOUZA, Prefeita do Município de São Paulo, usando das atribuições que Ihes são conferidas por lei, faz saber que a Câmara Municipal, em sessão de 13 de dezembro de 1990, decretou e ou promulgou a seguinte lei:

Art. $1^{\circ}$ - Define-se cortiço como a unidade usada como moradia coletiva multifamiliar, apresentando, total ou parcialmente, as seguintes características:

a) constituída por uma ou mais edificações construídas em lote urbano;

b) subdividida em vários cômodos alugados, subalugados ou cedidos a qualquer titulo;

c) várias funções exercidas no mesmo cômodo;

d) Acesso e uso comum dos espaços não edificados e instalações sanitárias;

e) Circulação e infra-estrutura, no geral precárias;

f) Superlotação de pessoas.

Art. $2^{\circ}$ - A prefeitura fiscalizará as condições de habitação nos cortiços e tomará as medidas necessárias para fazer respeitar as exigências da presente lei e demais normas pertinentes, atendendo as necessidades da população moradora.

Parágrafo único - Serão solidariamente responsáveis pelas condições de habitação, perante o poder Público, o proprietário, o locatário-sublocador, terceiros que tomem o lugar destes e / ou o responsável pela exploração do cortiço.

Art. $3^{\circ}$ - Independentemente de outras normas aplicáveis, consideram-se as condições mínimas de habitação, para os fins desta lei, as seguintes: 
a) segurança do imóvel no tocante à sua instalação elétrica e à sua estrutura, comprovadas através do laudo expedido pelo órgão público competente, renovado a cada dois anos;

b) iluminação mínima por cômodo 1/7 (um sétimo) da área de piso;

c) ventilação mínima por cômodo de metade da área de iluminação;

d) área mínima do cômodo ou divisão não inferior a $5 \mathrm{~m} 2$ (cinco metros quadrados), com sua menor dimensão não inferior a 2 (dois) metros;

e) adensamento máximo de 2 (duas) pessoas por $8 \mathrm{~m} 2$ (oito metros quadrados), considerando toda a área construída da edificação ,vedado o revezamento;

f) banheiro revestido de piso lavável e de barra impermeável até 2 (dois) metros de altura;

g) os banheiros serão dotados, pelo menos, de vaso sanitário, lavatório e chuveiro em funcionamento, compartimentos, sempre que possível, de forma independente, com abertura para o exterior;

h) haverá no mínimo 1 (um) tanque, 1 (uma) pia e 1 (um) banheiro para cada grupo de 20 (vinte) moradores;

i) o pé direito será de, no mínimo, 2,30m (dois metros e trinta centímetros);

j) as escadas e corredores de circulação terão, pelo menos, 80 (oitenta) centímetros de largura;

Parágrafo único - A Prefeitura poderá, em casos excepcionais, tolerar padrões inferiores àqueles previstos nas alíneas "b", "c", “d", "e", “i”, e “j”, se comprovar que as características concretas do imóvel apresentam condições razoáveis de habitabilidade.

Artigo $4^{\circ}$ - A prefeitura orientará e coordenará, quando for o caso, a assinatura de convênios entre o proprietário do imóvel, o locatário-sublocador e / ou os moradores e as empresas concessionárias de serviços de distribuição de energia elétrica, gás e de redes de água e esgoto, visando a melhoria das condições de habitabilidade.

Art. $5^{\circ}$ - O proprietário do imóvel, o locatário-sublocador, terceiros que tomem o lugar destes e/ou responsável pela exploração do cortiço, afixarão obrigatoriamente em quadro mantido em local visível, o laudo referido no artigo $3^{\circ}$, 
alínea "a", bem como as contas de água, energia elétrica, gás e similares, de forma a comprovar, perante os moradores, o consumo, o valor e sua quitação.

Parágrafo único - Do quadro de que se trata o "caput" deste artigo deverá constar, também, o nome e endereço completos do proprietário, bem como do locatário sub-locador, de terceiros que tomem o lugar destes e / ou do responsável pela exploração do cortiço.

Artigo $6^{\circ}$ - A fiscalização dos preceitos da legislação pertinente a cortiços fica a cargo da Prefeitura, através de seus órgãos competentes.

Parágrafo Único - Fica instituído o cadastro obrigatório, perante a prefeitura, dos imóveis enquadrados na categoria de cortiços.

Artigo $7^{\circ}$ - As infrações à presente lei serão objeto de 2 (duas) notificações consecutivas para sua correção plena , as quais estabelecerão prazos para as providências determinadas.

Parágrafo $1^{\circ}$ - Desatendidas as notificações da autoridade, será aplicada aos infratores a multa de 20 (vinte) a 200 (duzentas) UFMs, sem prejuízo de sujeitar-se o imóvel à declaração de utilidade pública ou de interesse social para fins de desapropriação, neste caso mantida sua destinação residencial pelo Poder Público.

Parágrafo $2^{\circ}$ - Quando as condições físicas e de habitabilidade do cortiço evidenciarem grave e iminente risco à vida ou à saúde dos moradores, a autoridade municipal competente, mediante laudo fundamentado, o interditará, sem prejuízo das sanções administrativas e penais a que estiverem sujeitos o proprietário, o locatário-sublocador, terceiros que tomarem o lugar destes e/ou o responsável pela exploração, ou, se julgar conveniente, realizará de imediato, as obras necessárias à eliminação do risco, delas se ressarcindo ulteriomente.

Artigo $8^{\circ}$ - O Executivo poderá criar programas específicos, voltados para a melhoria dos cortiços e sua adequação aos parâmetros previstos nesta lei, através de financiamentos, assistência técnica e outras formas, mediante contratos coletivos firmados entre as entidades representativas dos moradores e proprietário, garantindo sempre a permanência dos primeiros por prazo a ser ajustado em função do investimento previsto.

Artigo $9^{\circ}$ - Os terrenos vazios, resultantes da demolição de imóveis residenciais, sofrerão tributação progressiva, nos termos da lei pertinente. 
Artigo 10 - Os cortiços com mais de 50 (cinqüenta) moradores, deverão eleger comissão para os representar perante órgãos públicos.

Artigo 11 - A população moradora de cortiços, através de seus procuradores, suas entidades representativas ou de outra formas de organização, terão o direito de solicitar ao Poder Público Municipal informações sobre a situação do imóvel, no aspecto físico ou jurídico, bem como a fiscalização das condições de habitabilidade.

Artigo 12 - A presente lei será regulamentada, no que couber, por ato do Executivo,

Artigo 13 - As despesas decorrentes da execução desta lei correrão por conta das verbas orçamentárias próprias.

Artigo 14 - Esta lei entrará em vigor na data de sua publicação, revogadas as disposições em contrário.

PREFEITURA DO MUNICÍPIO DE SÃO PAULO, aos 8 de janeiro de $1991,437^{\circ}$ da fundação de São Paulo.

LUIZA ERUNDINA DE SOUSA, PREFEITA.

WALTER PIVA RODRIGUES, Respondendo pelo Cargo de Secretário dos Negócios Jurídicos.

AMIR ANTONIO KHAIR, Secretário das Finanças.

JOSÉ CARLOS PEGOLARO, Secretário das Administrações Regionais.

ERMÍNIA TEREZINHA MENON MARICATTO, Secretária da Habitação e Desenvolvimento Urbano.

PAUL ISRAEL SINGER, Secretário Municipal do Planejamento.

LADISLAS DOWBOR, Secretário dos Negócios Extraordinários.

Publicada na Secretaria do Governo Municipal, em 8 de janeiro de 1991.

JOSÉ EDUARDO MARTINS CARDOZO, Secretário do Governo Municipal. 


\section{ANEXO B - Decreto que regulamenta a Lei Moura.}

DECRETO No 33.189, de 17 de Maio de 1993

Regulamenta a Lei $n^{\circ} 10.928$, de 8 de janeiro de 1991, revoga o Decreto $n^{\circ}$ 30.731, de 12 de dezembro de 1991, e dá outras providências.

Paulo Maluf, Prefeito do Município de São Paulo, usando das atribuições que Ihe são conferidas por lei,

DECRETA:

Art. $1^{\circ}$ - Considera-se cortiço a unidade usada como moradia multifamiliar, horizontal ou vertical, e que apresente, total ou parcialmente, as seguintes características:

a) constituir-se por uma ou mais edificações construídas em lote urbano;

b) subdividir-se em vários cômodos alugados, subalugados ou cedidos ao morador a qualquer título;

c) abrigar várias funções no mesmo cômodo;

d) possuir, em comum, os acessos, assim como o uso dos espaços não edificados e das instalações sanitárias;

e) possuir circulação e instalações, em geral, precárias;

f) abrigar superlotação de pessoas.

Parágrafo único - Considera-se como característica essencial do cortiço aquela prevista na alínea "c" deste artigo.

Art. $2^{\circ}$ - Sem prejuízo da aplicação de outras normas, são condições mínimas de habitabilidade dos cortiços:

a) segurança do imóvel, no tocante à sua instalação elétrica e estrutura;

b) ventilação mínima por cômodo de $1 / 2$ (metade) da área de iluminação;

c) iluminação mínima por cômodo de 1/7 (um sétimo) da área do piso;

d) área mínima do cômodo ou divisão não inferior a 5,00m2 (cinco metros quadrados), com sua menor dimensão não inferior a 2,00m (dois metros); 
e) adensamento máximo de 2 (duas) pessoas por 8,00m2 (oito metros quadrados), considerando toda a área construída da edificação, vedado o revezamento;

f) banheiro revestido de piso lavável e de barra impermeável;

g) banheiro com abertura para exterior, dotado de vaso sanitário, lavatório e chuveiro em pleno funcionamento, com água quente, compartimento, sempre que possível, de forma independente;

h) um tanque, uma pia e um banheiro para cada grupo de 20 (vinte) moradores;

i) pé direito mínimo de 2,30 $\mathrm{m}$ (dois metros e trinta centímetros);

j) escada e corredores de circulação contendo, no mínimo, 0,80m (oitenta centímetros)) de largura.

Art. $3^{\circ}$ - Em casos excepcionais, se comprovada a salubridade do imóvel quanto às condições de umidade, aeração e iluminação, poderão ser tolerados padrões inferiores aos previstos nas alíneas "b", "c", "d", "e", “i” e "j" do artigo $2^{\circ}$ deste decreto, dentro dos seguintes parâmetros:

a) iluminação mínima por cômodo igual a 1/10 (um décimo) da área do piso;

b) área mínima do cômodo de $2,70 \mathrm{~m} 2$ (dois metros e setenta centímetros quadrados), com menor dimensão não inferior a 1,50m (um metro e cinqüenta centímetros), exigindo-se que os bujões de gás estejam situados em ambientes externos aquele onde estejam os queimadores;

c) adensamento máximo mantendo a relação de $2,00 \mathrm{~m} 2$ (dois metros quadrados) por pessoa em cada cômodo habitável;

d) escadas e corredores de circulação com largura de 0,60m (sessenta centímetros), desde que a edificação tenha dois pavimentos e área construída total até $250,00 \mathrm{~m} 2$ (duzentos e cinquenta metros quadrados).

Art. $4^{\circ}$ - A fim de fiscalizar as condições de habitabilidade nos cortiços, fica mantida a Comissão de Intervenção e Recuperação dos Cortiços, órgão colegiado da Prefeitura, responsável pelo gerenciamento das medidas necessárias ao atendimento das exigências da legislação em vigor, em especial as contidas na Lei no 10.928, de 8 de janeiro de 1991. 
Art. $5^{\circ}$ - A Comissão de Intervenção e Recuperação dos Cortiços é composta por 7 (sete) membros, na seguinte conformidade:

I - Três representantes da Secretaria da Habitação e Desenvolvimento Urbano - SEHAB, sendo obrigatoriamente um da Superintendência de Habitação Popular - HABI e um do Departamento de Controle do Uso de Imóveis - CONTRU;

II - Um representante da Secretaria das Administrações Regionais - SAR;

III - Um representante da Secretaria Municipal da Saúde - SMS

IV - Um representante da Secretaria da Família e Bem-Estar Social - FABES;

V - Um representante da Secretaria dos Negócios Jurídicos - SJ;

Parágrafo $1^{\circ}$ - Os membros da Comissão serão indicados pelos titulares das respectivas Pastas e designados pelo Prefeito.

Parágrafo $2^{\circ}$ - A coordenação da Comissão será exercida por indicação do Secretário da Habitação e Desenvolvimento Urbano, dentre os representantes da Pasta.

Art. $6^{\circ}$ - São atribuições da Comissão de Intervenção e Recuperação dos Cortiços:

I. Sistematizar as informações sobre a situação dos imóveis enquadrados na categoria de cortiço, quanto aos aspectos físico e jurídico;

II. Assegurar os meios necessários para a promoção do cadastro dos imóveis enquadrados na categoria de cortiços;

III. Orientar e coordenar, quando for o caso, a assinatura de convênios entre o proprietário do imóvel, o locatário-sublocador e/ou os moradores e as empresas, concessionárias de serviços de distribuição de energia elétrica, de gás, de rede de água e esgoto, visando melhorar as condições de habitabilidade;

IV. Assegurar programas e convênios para o atendimento de exigências feitas pelo Poder Público, visando a obtenção do Certificado de Uso do Imóvel;

V. Fiscalizar a existência obrigatória de quadro, afixado em lugar visível, contendo:

a. Certificado de Uso do Imóvel;

b. contas de água, energia elétrica, gás e outras de natureza coletiva, de forma acomprovar aos moradores o valor e a quitação; 
c. a perfeita identificação do proprietário do imóvel, bem como do locatário-sublocador, de terceiros que tomem o lugar destes ou do responsável pela exploração do cortiço, com nome completo, R.G., ClC e endereço correto.

Art. $7^{\circ}$ - Por ocasião da fiscalização prevista no artigo $4^{\circ}$ deste decreto, os imóveis que possuírem as características relacionadas no artigo $1^{\circ}$ da Lei $n^{\circ}$ 10.928/9, serão enquadrados na categoria de cortiços, podendo ser solicitado ao órgão competente o Certificado de Uso do Imóvel, que abrangerá principalmente:

a) estado das instalações elétricas;

b) estabilidade da edificação

c) potencial de risco de incêndio e presença de equipamentos de prevenção e combate;

d) outros elementos considerados pertinentes para a segurança na ocupação do imóvel.

Art. $8^{\circ}$ - O Certificado de Uso do Imóvel, renovável a cada dois anos, será fornecido, após o cumprimento das providências apontadas como necessárias em vistoria conjunta, realizada pelos técnicos dos órgãos envolvidos, que elaborarão parecer sobre a situação geral do imóvel, quanto ao aspecto físico da construção, situações de risco ou prejudiciais à saúde dos moradores.

Parágrafo $1^{\circ}$ - Quando a área construída for menor ou igual a 250,00m2 (duzentos e cinqüenta metros quadrados), com até dois pavimentos e número de moradores menor ou igual a 120 (cento e vinte), o Certificado de Uso do Imóvel será expedido pela Administração Regional competente, da Secretaria das Administrações Regionais - SAR, sendo dispensada a apresentação de Laudo Técnico de Segurança;

Parágrafo $2^{\circ}$ - Nos demais casos, o Certificado de Uso do Imóvel será expedido pelo Departamento de Controle do Uso de Imóveis - CONTRU, da Secretaria de Habitação e Desenvolvimento Urbano - SEHAB, com apresentação por parte do proprietário do imóvel ou dos moradores, de Laudo Técnico de Segurança, quando cabível, ou de parecer elaborado pelo próprio Departamento de Controle do Uso de Imóveis - CONTRU. 
Art. $9^{\circ}$ - A Prefeitura, através do Departamento de Controle do Uso de Imóveis - CONTRU ou da Administração Regional competente, conforme o caso , procederá à imediata interdição do cortiço quando:

I. Em vistoria técnica, for constatada a existência de risco grave e iminente para os moradores ou vizinhança;

II. Em vistoria conjunta com a Secretaria Municipal da Saúde, for constatada a existência de risco grave e iminente à vida ou à saúde dos moradores do cortiço.

Parágrafo $1^{\circ}$ - Constatada a necessidade de interdição, cabe à Comissão de Intervenção e Recuperação dos Cortiços solicitar, ao órgão competente da Prefeitura, a imediata remoção dos moradores e sua instalação provisória, até que se recupere o imóvel ou que o removido encontre moradia.

Parágrafo $2^{\circ}$ - Interditado o cortiço , a Prefeitura aplicará as sanções e demais medidas cabíveis ao proprietário do imóvel, ao locatário-sublocador, a terceiros que tomem lugar destes ou ao responsável pela exploração do cortiço.

Art. $10^{\circ}$ - Ocorrendo a interdição por risco grave e iminente, a Prefeitura adotará o seguinte procedimento:

I. Intimar o proprietário do imóvel, o locatário-sublocador, terceiros que tomem o lugar destes ou o responsável pela exploração do cortiço, para execução de obras ou serviços necessários à eliminação do risco, nos termos da legislação em vigor;

II. Desatendida a intimação prevista no inciso anterior, providenciar a imediata realização das obras de segurança necessárias à eliminação do risco, ressarcindo-se posteriormente, nos termos da legislação em vigor;

Decretar a desapropriação do imóvel, nos casos considerados de interesse social.

Parágrafo único - $O$ procedimento previsto neste artigo poderá ser adotado também em relação aos cortiços que não apresentem risco grave e iminente, dependendo das condições de habitabilidade a critério da Comissão de Intervenção e Recuperação dos Cortiços, sem prejuízo da adoção de outras formas de ação.

Art. $11^{\circ}$ - A Comissão de Intervenção e Recuperação dos Cortiços, visando a realização das atribuições a ela conferidas, por este decreto, deverá elaborar plano 
de ação definindo as áreas de atuação prioritárias, inclusive no tocante à fiscalização, podendo criar, quando necessário, subcomissões regionalizadas, bem como solicitar a colaboração de outros órgãos da Prefeitura.

Art. $12^{\circ}$ - A Comissão de Intervenção e Recuperação dos Cortiços poderá criar programas específicos voltados para a melhoria dos cortiços e de orientação aos moradores, que contem inclusive com financiamento para assistência técnica e jurídica, entre outras.

Parágrafo único - Para prestação do serviço de assistência jurídica gratuita à população moradora em cortiço, a Prefeitura poderá firmar convênios com órgãos públicos ou instituições, nos termos da Lei n 11.300, de 9 de dezembro de 1992.

Art. $13^{\circ}$ - Sem prejuízo dos demais programas desenvolvidos pela Secretaria de Habitação e Desenvolvimento Urbano - SEHAB, ou que venham a ser criados, ficam instituídos, no âmbito da Superintendência de Habitação Popular - HABI, os seguintes programas de intervenção nos cortiços:

I. Programa de Recuperação, Renovação e Regularização de áreas com concentração de cortiços, com financiamento para a produção de unidades habitacionais de interesse social destinadas à população moradora em cortiço;

II. Programa de financiamento para a realização de reformas, ampliações ou reconstruções dos imóveis enquadrados na categoria de cortiço, observadas as normas pertinentes;

III. Programa de assistência técnica, visando a elaboração de Laudo Técnico e o atendimento das demais exigências do Poder Público, para a obtenção do Certificado de Uso do Imóvel.

Parágrafo $1^{\circ}$ - Para a operacionalização dos programas serão utilizados os recursos do Fundo de Atendimento a População Moradora em Habitação SubNormal - FUNAPS, mediante aprovação do Conselho Deliberativo do Fundo, dentro dos critérios estabelecidos.

Parágrafo $2^{\circ}$ - Para efeito do programa previsto no inciso II, poderá ser firmado contrato entre o proprietário e os moradores, de modo a garantir a permanência destes últimos no imóvel em prazo condizente com o investimento público. 
Art. $14^{\circ}$ - Compete à Superintendência de Habitação Popular - HABI exercer a supervisão e fiscalização de todas as fases dos programas previstos no artigo 13 deste decreto, e de todos os contratos e convênios deles decorrentes, cabendo-lhe verificar o cumprimento das normas e regulamentos pertinentes, bem como estimular a formação e organização dos moradores de cortiços em associações ou entidades representativas, para discussão e acompanhamento dos projetos a serem realizados, além de prepará-los para futura administração conjunta da nova moradia.

Art. $15^{\circ}$ - As demais normas e procedimentos referentes aos programas de que trata este decreto serão estabelecidas por instrução da Superintendência de Habitação Popular - HABI.

Art. $16^{\circ}$ - Os moradores dos cortiços, poderão eleger Comissão para representá-los perante os órgãos públicos.

Art. $17^{\circ}$ - A população moradora dos cortiços, através de seus representantes, poderá solicitar à Comissão de Intervenção e Recuperação dos Cortiços vistoria nos imóveis com as características previstas na Lei $n^{\circ} 10.928$, de 8 de janeiro de 1991, ocasião em que estes serão cadastrados nos termos deste decreto.

Art. $18^{\circ}$ - Os moradores dos cortiços, através de seus representantes, poderão:

I. Solicitar à Comissão de Intervenção e Recuperação dos Cortiços informações sobre a situação do imóvel em que residem, quanto aos aspectos físico e jurídico;

II. Solicitar a fiscalização das condições de habitabilidade do cortiço em que residem;

III. Solicitar o atendimento habitacional, através dos programas específicos de moradia para a população dos cortiços;

IV. Solicitar serviço de assistência jurídica gratuita;

V. Solicitar serviço de assistência técnica, para a elaboração do Laudo Técnico;

VI. Denunciar à Comissão de Intervenção e Recuperação dos Cortiços a omissão, abuso ou qualquer desrespeito aos dispositivos da legislação em vigor, em especial da Lei $n^{\circ} 10.928$, de 8 de janeiro de 1991;

VII. Participar das discussões referentes às Ações Setoriais, visando a operacionalização das intervenções. 
Art. $19^{\circ}$ - O proprietário do imóvel, o locatário-sublocador, terceiros que tomem o lugar destes ou o responsável pela exploração do cortiço a qualquer título, sujeitam-se às seguintes multa:

I. Por não afixar o quadro exigido no artigo $6^{\circ}$, inciso $\mathrm{V}$, deste decreto 50 (cinqüenta) Unidades de Valor Fiscal do Município de São Paulo UFM;

II. Pela manutenção do quadro com informações incompletas - 30 (trinta) Unidades de Valor Fiscal do Município de São Paulo - UFM;

III. Por deixar de prestar corretamente as informações solicitadas pela Comissão de Intervenção e Recuperação dos Cortiços - 90 (noventa) Unidades de Valor Fiscal do Município de São Paulo - UFM;

IV. Por deixar de atender às exigências da Comissão de Intervenção e Recuperação dos Cortiços, relativas às de habitabilidade do cortiço 200 (duzentas) Unidades de Valor Fiscal do Município de São Paulo UFM.

Parágrafo único - Pelo desatendimento a qualquer exigência relativa às condições de segurança e habitabilidade do cortiço, serão aplicadas as multas previstas na coluna I do quadro IV, anexa à Lei n 9.433 , de $1^{\circ}$ de abril de 1982

Art. $20^{\circ}$ - Este decreto entrará em vigor na data de sua publicação, revogadas as disposições em contrário e, em especial, o Decreto $n^{\circ} 30.731$, de 12 de dezembro de 1991.

PREFEITURA DO MUNICÍPIO DE SÃO PAULO, aos 17 de maio de $1993,440^{\circ}$ da fundação de São Paulo.

PAULO MALUF, PREFEITO.

CORNÉLIO VIEIRA DE MORAIS JUNIOR, Secretário dos Negócios Jurídicos. CELSO ROBERTO PITTA DO NASCIMENTO, Secretário das Finanças.

ANTÕNIO SALIM CURIATI, Secretário Municipal da Família e Bem-Estar Social.

RAUL CUTAIT, Secretário Municipal da Saúde.

RICARDO NAGIB IZAR, Secretário das Administrações Regionais.

JOÃO MELLÃO NETO, Secretário da Habitação e Desenvolvimento Urbano.

Publicado na Secretaria do Governo Municipal, em 17 de maio de 1993.

EDEVALDO ALVES DA SILVA, Secretário do Governo Municipal. 


\section{ANEXO C - Resolução do Programa de Cortiços do Conselho Municipal de Habitação de São Paulo.}

Resolução CMH n ${ }^{\circ}$ 15, de 07 de dezembro de 2004

Aprova o Programa de Cortiços - Reabilitação da Moradia Coletiva

O Conselho Municipal de Habitação - $\mathrm{CMH}$, de acordo com a Lei $\mathrm{n}^{\circ}$ 11.632/94 e com a Lei no 13.425/02, e

CONSIDERANDO as péssimas condições de habitabilidade e salubridade das edificações encortiçadas e a relação de exploração e informalidade nos contratos de locação e suas conseqüências no agravamento da qualidade de vida dos moradores de cortiço;

CONSIDERANDO que o Estatuto da Cidade e o Plano Diretor Estratégico, por meio das ZEIS 3, definem diretrizes para as regiões com concentração de cortiços, visando a intervenção em situações habitacionais precárias para garantir condições dignas de habitabilidade;

CONSIDERANDO a possibilidade de melhoria das condições de habitação por meio de melhoria das edificações já existentes;

CONSIDERANDO que o Programa de Cortiços envolve um conjunto de ações que terão maior efeito se forem acompanhadas da possibilidade de financiamento de melhorias dos cortiços pelo Poder Público e

CONSIDERANDO que foi iniciado um processo de fiscalização gerenciado pela CIRC - Comissão de Intervenção e Recuperação dos Cortiços e que o financiamento evitará a expulsão da população moradora nos imóveis atingidos;

RESOLVE:

I - Aprovar o PROGRAMA DE CORTIÇOS, como disposto nos dois anexos desta Resolução.

II - A SEHAB deverá, no prazo de 60 (sessenta) dias, publicar as instruções normativas necessárias à operacionalização das normas estabelecidas nesta Resolução.

III - Esta Resolução entra em vigor na data da sua publicação, ficando revogadas as disposições em contrário. 


\section{MARCOS BARRETO}

Presidente do Conselho Municipal de Habitação

\section{ANEXO I - PROGRAMA DE CORTIÇOS}

Este anexo define as diretrizes e indica os procedimentos a serem adotados no Programa de Cortiços, independentemente de ser concedido financiamento com recursos do FMH.

\section{OBJETIVO}

Melhorar as condições de habitabilidade dos cortiços, adequando-os no mínimo aos padrões da Lei Municipal n 10.928/91 - Lei de Cortiços, assim como a qualidade de vida dos moradores.

Espera-se também, com as intervenções do poder público, que os proprietários e responsáveis por esses imóveis reconheçam sua responsabilidade sobre as condições de moradia que disponibilizam e que essas ações irradiem o alcance das melhorias para além dos imóveis diretamente atingidos.

\section{DIRETRIZES GERAIS DO PROGRAMA}

1. O Programa de Cortiços parte da realidade das famílias que vivem nos cortiços, em condições precárias, buscando garantir, no mínimo, o que a lei assegura como parâmetro de habitabilidade e segurança. Para isso, compreende ações integradas e complementares de mapeamento, capacitação dos moradores, fiscalização desses imóveis e intervenção para a realização de melhorias.

2. Para os fins deste Programa e nos termos da Lei Municipal $n^{0} 10.928 / 91$, entende-se como cortiço a unidade usada como moradia coletiva multifamiliar, apresentando, total ou parcialmente, as seguintes características:

a) constituída por uma ou mais edificações construídas em lote urbano;

b) subdividida em vários cômodos alugados, subalugados ou cedidos a qualquer título;

c) várias funções exercidas no mesmo cômodo;

d) acesso e uso comum dos espaços não edificados e instalações sanitárias;

e) circulação e infra-estrutura, no geral, precárias;

f) superlotação de pessoas.

2.1 Considera-se como característica essencial do cortiço aquela prevista na alínea "c" do item anterior. 
3. O Programa será desenvolvido pela SEHAB em parceria com a CIRC Comissão de Intervenção e Recuperação de Cortiços, conforme previsto pelo Decreto 33.189/93.

4. A CIRC é um órgão colegiado intersecretarial da Prefeitura responsável pelo gerenciamento das medidas necessárias ao atendimento das exigências da legislação em vigor e para isso contará com a assessoria da Superintendência de Habitação Popular - HABI.

4.1 A CIRC possui sete membros, dentre os quais três representantes da Secretaria de Habitação e Desenvolvimento Urbano - SEHAB; um representante da Secretaria Municipal das Subprefeituras - SMSP; um representante da Secretaria Municipal de Saúde - SMS; um representante da Secretaria de Assistência Social SAS; um representante da Secretaria de Negócios Jurídicos - SJ.

5. A Superintendência de Habitação Popular - HABI, a partir de metodologias, conceitos de cortiços e dos objetivos do mapeamento, montará um banco de dados de cortiços, que terá dois graus de informações:

a) Grau 1: identificação dos cortiços na cidade, auxiliando a emissão de Certificados de Habitação Coletiva Multifamiliar;

b) Grau 2: caracterização do imóvel e cadastramento da demanda em caso de intervenção.

5.1 O mapeamento contará com os dados existentes da Secretaria de Habitação, ou obtidos por meio das vistorias realizadas por HABI, das informações existentes em outras Secretarias, entidades e Institutos de Pesquisas.

6. A Comissão de Cortiços, instituída na $4^{\mathrm{a}}$ Reunião Ordinária do $\mathrm{CMH}$, realizada em 29 de março de 2004 , fica mantida, para a continuidade da discussão deste Programa.

III - DESCRIÇÃO DO PROGRAMA

O Programa será estruturado em três eixos:

a) capacitação dos moradores de cortiços;

b) fiscalização para adequação dos imóveis encortiçados à Lei de Cortiços;

c) intervenção nos imóveis encortiçados.

1. Capacitação dos moradores de cortiços

1.1 A capacitação compreende o desenvolvimento das ações educativas visando contribuir para a construção da cidadania dos moradores de cortiços, com o 
intuito de possibilitar a participação decisória na formulação dos planos, programas e projetos voltados à melhoria das condições de moradia para este segmento social. Por outro lado, a capacitação dos moradores é um dos principais elementos de sustentabilidade, irradiação e desenvolvimento deste Programa.

1.2 A capacitação será desenvolvida por meio de oficinas, cursos, seminários, teatros, escutas nas ruas e outras formas, cujo principal instrumento é a cartilha "Cortiços e Pensões - Construindo Cidadania", que resume os direitos e deveres do morador de cortiço e do proprietário, para melhorar as condições de moradia.

1.3 O trabalho de capacitação deverá estar articulado com outras Secretarias, Movimentos de Moradia, Associações de Moradores, ONGs, Pastorais, Universidades, Entidades de Classes e outras instituições que desenvolvem ações sociais e, também, contribuir na área de formação para manutenção de imóvel, gestão da convivência e formação de agentes multiplicadores para a melhoria das condições de vida dos moradores de cortiços.

2. Fiscalização e adequação dos imóveis encortiçados à Lei de Cortiços

2.1 Anteriormente à fiscalização propriamente dita, a SEHAB poderá, conforme a Lei Municipal $n^{\circ} 13.297 / 02$, emitir a Declaração de Habitação Coletiva Multifamiliar, para que os moradores de cortiços possam requerer tarifas sociais referentes ao consumo de água e eletricidade.

2.2 Serão gerenciadas pela CIRC ações de fiscalização, realizadas pela Subprefeitura competente, das condições de moradia, de acordo com a Lei Municipal $n^{\circ} 10.928 / 91$, e se necessário serão aplicadas multas e até a interdição. Quando o cortiço estiver de acordo com os padrões da Lei Municipal n 10.928/91, será expedida a Declaração de adequação do imóvel às condições de habitabilidade.

2.3 A CIRC operará segundo Planos de Ação, que serão traçados a partir das seguintes prioridades:

a) os casos indicados pelos Programas de Reabilitação Integrada do Habitat PRIHs;

b) os casos em que já houver uma predisposição do proprietário para realizar as melhorias, o que será verificado a partir de contatos realizados no âmbito de programas desenvolvidos pela SEHAB; 
c) os casos de determinação e/ou acordo judicial entre locatários, intermediários e proprietários e/ou termo de ajustamento de conduta entre locatários, intermediários e proprietários perante o Ministério Público;

d) os casos em que a demanda já tenha atendimento garantido por outra entidade pública ou privada que estiver atuando em parceria com o Poder Público Municipal.

2.4 Os procedimentos de fiscalização terão como objetivo incentivar o proprietário ou responsável pelo cortiço a realizar melhorias que adeqüem o cortiço aos padrões da legislação, e, se estas não forem realizadas, serão impostas multas aos proprietários ou responsáveis pelo imóvel. No caso de risco iminente, poderá haver inclusive a interdição do imóvel, levando o Poder Público a promover uma solução habitacional para as famílias moradoras.

3. Intervenção nos cortiços

3.1 A intervenção nos cortiços poderá ser feita das seguintes maneiras:

a) em parceria com outras entidades públicas ou privadas;

b) por meio de determinações ao proprietário, que realizará as melhorias necessárias com seus próprios recursos;

c) por meio de determinações ao proprietário, que realizará as melhorias com financiamentos concedidos com recursos do Fundo Municipal de Habitação - FMH, de acordo com as regras estabelecidas no Anexo II desta Resolução.

3.2 Feitas as determinações pela CIRC, o proprietário ou responsável pelo cortiço deverá providenciar a elaboração de uma proposta das melhorias que pretende fazer.

3.3 A proposta de melhoria deverá ser submetida à CIRC para que esta avalie se é suficiente para adequação aos padrões mínimos da Lei Municipal n 10.928/91.

3.4 Por melhoria entende-se as pequenas reformas em que não é alterada a estrutura da edificação, tais como: pintura interna e externa; troca de revestimento; substituição e consertos em esquadrias e portas, sem modificação de vãos; troca de telhas ou elementos de cobertura; reparos em instalações elétricas e/ou hidráulicas. A pequena reforma que envolver remoção de divisórias ou de mezaninos adaptados enquadra-se na definição de melhoria para os fins desta Resolução.

3.4.1 No caso de acréscimo de área, conforme legislação vigente, o proprietário deverá apresentar à Subprefeitura projeto de aprovação. 
3.5 Após o cumprimento destas etapas, a proposta de melhoria deverá ser submetida à análise da Subprefeitura em cujo território se localize o cortiço, para que seja dada a autorização para a realização da melhoria.

3.6 As melhorias deverão garantir:

a) bom funcionamento das instalações hidráulicas e elétricas e adequadas instalações de gás, conforme o Decreto $n^{\circ} 24.714 / 87$;

b) condições de habitabilidade de acordo com os padrões da Lei $n^{0} 10.928 / 91$;

c) condições adequadas de salubridade e de saneamento básico.

3.7 Será comunicado à CIRC pelo proprietário ou responsável pelo imóvel o término das obras de melhoria e atestado por HABI ou pela Subprefeitura competente que aquelas foram realizadas de acordo com a proposta inicial.

3.8 Feita a comunicação do item anterior, será expedida a Declaração de adequação do imóvel às condições de habitabilidade.

\section{DEMANDA}

Os moradores de cortiços.

\section{ATENDIMENTO À DEMANDA}

1. O atendimento à demanda será feito conforme os tipos de intervenção elencados no Item III. 3.1 e por meio dos Programas desta Secretaria ou de outras entidades conveniadas que possibilitem o atendimento da população moradora de cortiços.

2. A definição de qual família será atendida dentro de cada um dos Programas será feita pela Superintendência de Habitação Popular - HABI.

VI. LEGISLAÇÃO DE APOIO

Lei Municipal $n^{\circ} 10.928$ de 08 de janeiro de 1991 e Decreto $n^{\circ}$ 33.189/93.

Lei Municipal no 13.425 de 02 de setembro de 2002.

Lei Municipal no 13.297 de 16 de janeiro de 2002.

Decreto $n^{\circ} 24.174$ de 7 de outubro de 1987.

ANEXO II - FINANCIAMENTO DE MELHORIAS COM RECURSOS DO FMH

Este anexo define as diretrizes e regras para o financiamento de melhorias nos cortiços com recursos do FMH, a partir das diretrizes definidas no Anexo I desta Resolução. 
1. Nos casos em que o proprietário se dispuser a cumprir as determinações da CIRC, mas não contar com recursos para tanto, a realização das melhorias poderá ser financiada com recursos do Fundo Municipal de Habitação, sempre com retorno, conforme condições a serem estabelecidas no contrato de financiamento.

2. Nas melhorias realizadas com recursos do $\mathrm{FMH}$, também deverão ser respeitados os padrões mínimos da Lei Municipal $n^{\circ} 10.928 / 91$, com as seguintes ressalvas:

a) serão respeitadas, sem qualquer exceção, os padrões estabelecidos no "caput" do artigo $3^{\circ}$ da Lei $n^{\circ} 10.928 / 91$;

b) será adotado o padrão mínimo de um banheiro completo, um tanque e uma pia para cada dez pessoas;

c) serão garantidas condições de segurança para as instalações de gás.

2.1 Se o proprietário se dispuser a realizar outras obras, além dos padrões mínimos da Lei Municipal n 10.928/91 e desta Resolução, que melhorem as condições de habitabilidade, estas também poderão ser financiadas com recursos do FMH até o limite do valor do financiamento.

3. Os agentes gestor e operador do FMH e outras entidades que dispuserem de recursos para este Programa poderão estabelecer parcerias para a concessão de financiamentos ao proprietário e para o atendimento da população moradora.

4. A proposta de melhoria deverá ser apresentada pelo proprietário, que demonstrará:

a) a propriedade do imóvel;

b) atendimento aos requisitos deste Anexo.

4.1 A verificação da viabilidade da proposta, conforme os itens 2 e 4 acima, será feita pela COHAB-SP por meio de:

a) análise da documentação do imóvel apresentada pelo proponente, que deverá constar de título de propriedade (escritura) e matrícula atualizada;

b) análise dos serviços e orçamento, apresentados pelo proponente;

c) análise do cronograma físico-financeiro, quando cabível, das melhorias apresentado pelo proponente;

d) análise das condições de habitabilidade existentes, feita por meio de relatório técnico com indicações de serviços a executar, elaborado pela COHAB-SP; 
d) nos casos em que haja acréscimo de área, projeto completo, apresentado pelo proponente, com respectivos ARTs (Atestados de Responsabilidade Técnica), nos termos da legislação vigente.

5. Após a aceitação da proposta técnica, será feito, pela Superintendência de Habitação Popular - HABI, um cadastramento das famílias, sendo definido quais serão as que permanecerão no imóvel e quais serão removidas e atendidas com os demais programas habitacionais.

5.1 Feita a definição do item anterior, será firmado o contrato de financiamento, de acordo com as regras estabelecidas nesta Resolução.

6. A liberação dos recursos será feita em etapas, conforme o cronograma físico-financeiro da obra, acompanhado por técnicos da COHAB-SP.

6.1 Nos casos de obras com acréscimo de área, conforme legislação vigente, o proprietário deverá apresentar comprovante de recolhimento da contribuição ao INSS da empresa responsável pela obra, para obtenção do Habite-se.

7. Será comunicado à CIRC pelo proprietário o término das obras de melhoria e atestado pela COHAB-SP que foram realizadas de acordo com a proposta inicial.

7.1 Feita a comunicação do item anterior, será expedida a Declaração de adequação do imóvel às condições de habitabilidade.

II. DIRETRIZES GERAIS DO FINANCIAMENTO DAS MELHORIAS

1. Todo financiamento de melhoria realizado com recursos do FMH será feito através de contrato em que figurarão como partes a COHAB-SP, como agente operador do $\mathrm{FMH}$, o proprietário e os moradores dos cortiços.

2. O valor máximo do financiamento das melhorias será de $R \$ 3.600,00$ (três mil e seiscentos reais) - reajustados anualmente pelo IPC-FIPE - por família que permanecer no imóvel após a execução da melhoria e também não poderá ultrapassar o valor do imóvel dado em garantia.

3. O imóvel sempre será oferecido em garantia ao financiamento.

4. Como condições do financiamento, sempre constará no contrato:

a) garantia do direito à permanência dos moradores pelo período de 30 (trinta) meses contados a partir do término das obras de reparos, desde que cumpridas as obrigações de locatários;

b) garantia de que os aluguéis não aumentem pelo período de 30 (trinta) meses, sendo permitida apenas a correção monetária anual, na forma da lei. 
4.1 A garantia do financiamento não poderá ser levantada pelo proprietário até a quitação do contrato de financiamento.

4.2 Será estabelecida, em cada contrato de financiamento, multa em decorrência do descumprimento das condições estabelecidas no item 4, no valor financiado correspondente a cada família atingida pelo descumprimento contratual.

5. Nos financiamentos de melhorias de imóveis de uso misto, a parte comercial do imóvel deverá ser melhorada somente naquilo que for estritamente necessário para a adequação da parte residencial aos padrões estabelecidos neste Anexo.

6. Será exigido do proprietário que sejam firmados com os moradores contratos de locação em forma escrita, sendo observadas todas as condições definidas nesta Resolução e na Lei Federal n 8.245/91.

\section{DAS CONDIÇÕES DE FINANCIAMENTO}

1. No financiamento concedido aos proprietários com recursos do Fundo Municipal de Habitação - FMH, serão aplicados juros de $8 \%$ ao ano, nos termos da legislação que regulamenta o $\mathrm{FMH}$.

2. As parcelas serão corrigidas pelo IPC - FIPE mensalmente.

3. O valor da parcela inicial será de, no mínimo, $20 \%$ (vinte por cento) da renda mensal que o proprietário obtiver com as famílias que permanecerem no imóvel.

4. O prazo de financiamento será de até 30 (trinta) meses.

5. Independentemente do prazo do financiamento convencionado entre as partes, a garantia de permanência das famílias no imóvel será dada para o período de 30 (trinta) meses.

\section{DO CONTRATO DE FINANCIAMENTO}

1. No contrato de financiamento, serão partes a COHAB-SP e o proprietário do cortiço objeto da melhoria, e figurarão como partes beneficiárias os moradores, que terão suas moradias com melhores condições e garantias decorrentes do próprio financiamento.

2. O contrato terá os seguintes itens obrigatórios:

a) valor e prazo do financiamento;

b) a especificação das melhorias;

c) a identificação das famílias que permanecerão no imóvel; 
d) as garantias dadas a essas famílias de permanência no imóvel e de manutenção do valor do aluguel, pelo período de 30 (trinta) meses;

e) a garantia dada ao financiamento.

3. A família que decidir sair do imóvel antes dos 30 (trinta) meses deverá comunicar à COHAB-SP a saída espontânea, afastando a responsabilidade do proprietário sobre a sua saída.

\section{DOS AGENTES DO PROGRAMA}

\section{São agentes do Programa:}

Agente gestor: Secretaria Municipal de Habitação e Desenvolvimento Urbano - SEHAB;

Agente operador: Companhia Municipal de Habitação - COHAB-SP;

c) Agente promotor: proprietário.

2. As competências dos agentes Gestor e Operador, além das já definidas em lei, e no que diz respeito especificamente a este Programa, são as definidas neste item.

\subsection{Caberá à SEHAB:}

a) propor ao Conselho Municipal de Habitação as metas anuais de alocação de recursos para o Programa, especificando o que será destinado ao financiamento aos proprietários e o que será destinado ao atendimento por meio de outros programas;

b) definir a demanda do Programa;

c) acompanhar e avaliar o andamento do Programa, zelando pelo seu fiel cumprimento, executando as medidas que para isso forem necessárias;

d) encaminhar a solução habitacional a ser dada para as famílias que forem removidas dos cortiços.

\subsection{Caberá à COHAB-SP:}

operacionalizar a concessão do financiamento aos proprietários dos cortiços; acompanhar o cumprimento, pelos proprietários, das melhorias que foram objeto do contrato de financiamento;

elaborar a prestação de contas, anual e mensalmente, dos recursos despendidos pelo Programa, assim como os relatórios para o monitoramento de SEHAB, por meio de HABl;

tomar as medidas necessárias para a operacionalização eficaz do Programa. 
3. Caberá ao agente promotor:

a) realizar a melhoria tal como estabelecido na proposta apresentada pelo proprietário e aprovada pela COHAB-SP no contrato de financiamento;

b) cumprir as condições estabelecidas nos contratos;

c) prestar informações sempre que necessário para o gerenciamento do Programa.

\section{FONTES DE RECURSOS}

Os recursos utilizados para este Programa serão oriundos do Fundo Municipal de Habitação, sem prejuízo de outros provenientes de parcerias e convênios com instituições públicas e privadas, celebrados nos termos da legislação que regulamenta o $\mathrm{FMH}$.

\section{LEGISLAÇÃO DE APOIO}

Lei Municipal no 10.928 de 08 de janeiro de 1991 e Decreto $n^{\circ} 33.189 / 93$.

Lei Municipal no 11.632 de 22 de julho de 1994 e Decreto n 44.594/04.

Lei Municipal no 13.425 de 02 de setembro de 2002.

Lei Federal no 8.245 de 18 de outubro de 1991. 
ANEXO D - Fotografias realizadas em "Vistorias Prévias" de imóveis encortiçados - Fachadas.

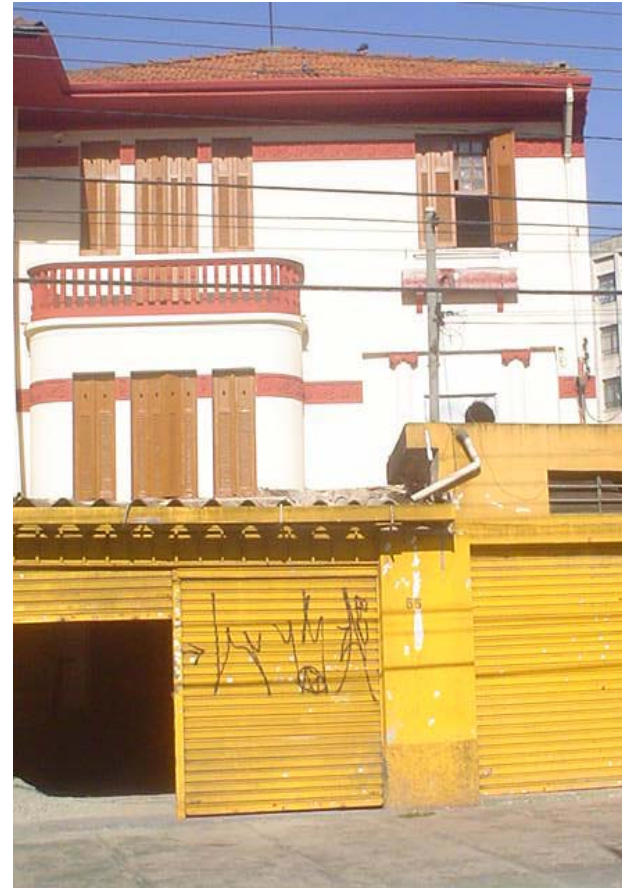

Foto 1 - Rua Angélica, 41.

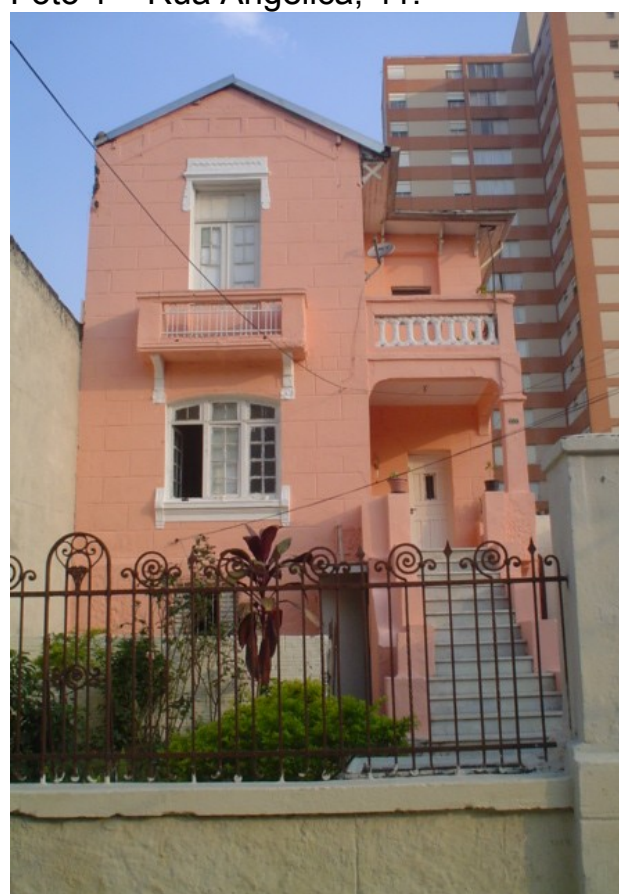

Foto 3 - Avenida Celso Garcia, 2552.

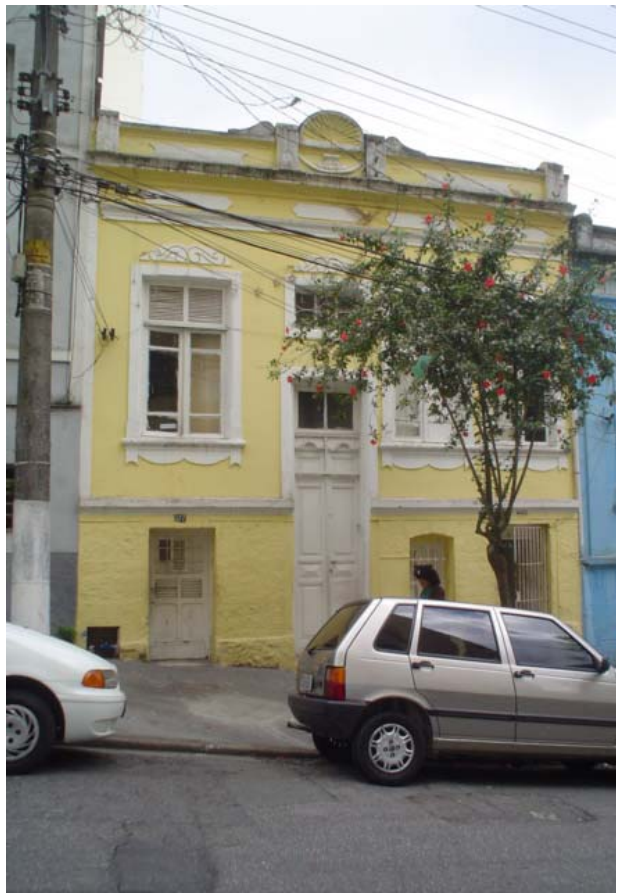

Foto 2 - Rua Artur Prado, 270.

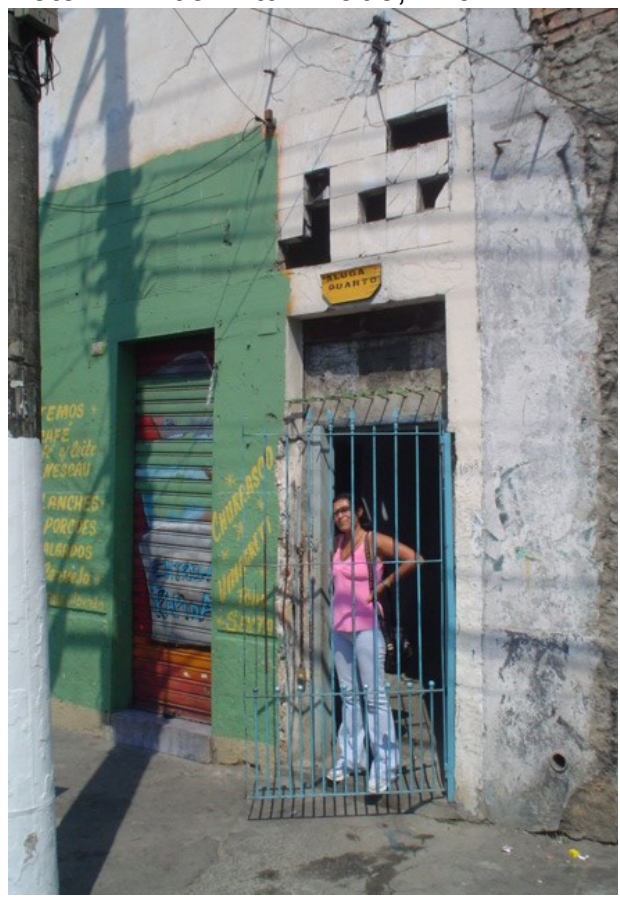

Foto 4 - Avenida Celso Garcia,1648. 


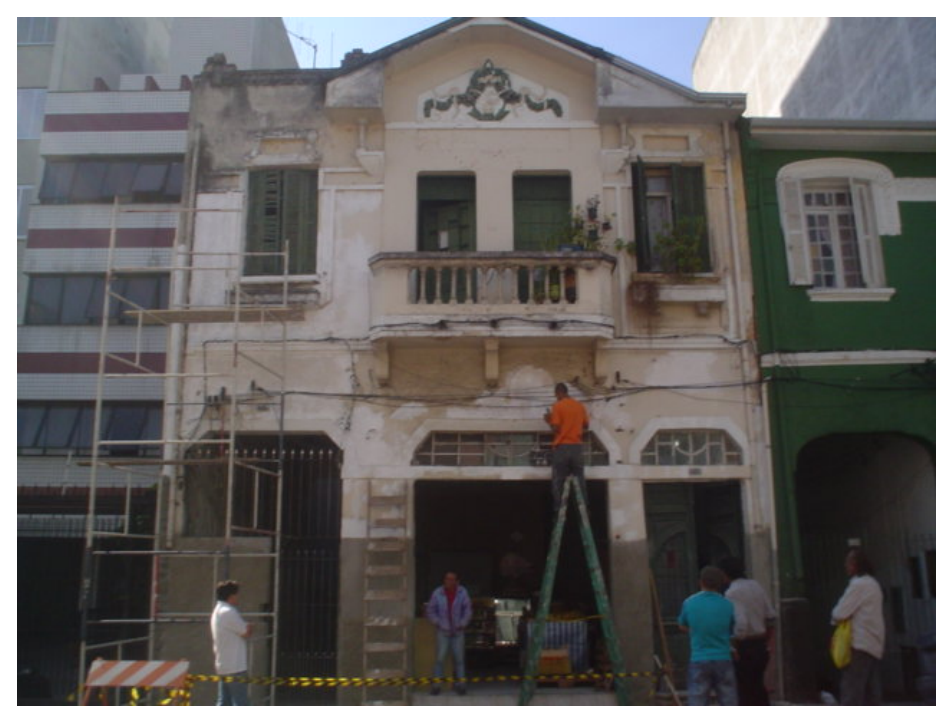

Foto 5 - Rua Abolição, 359.

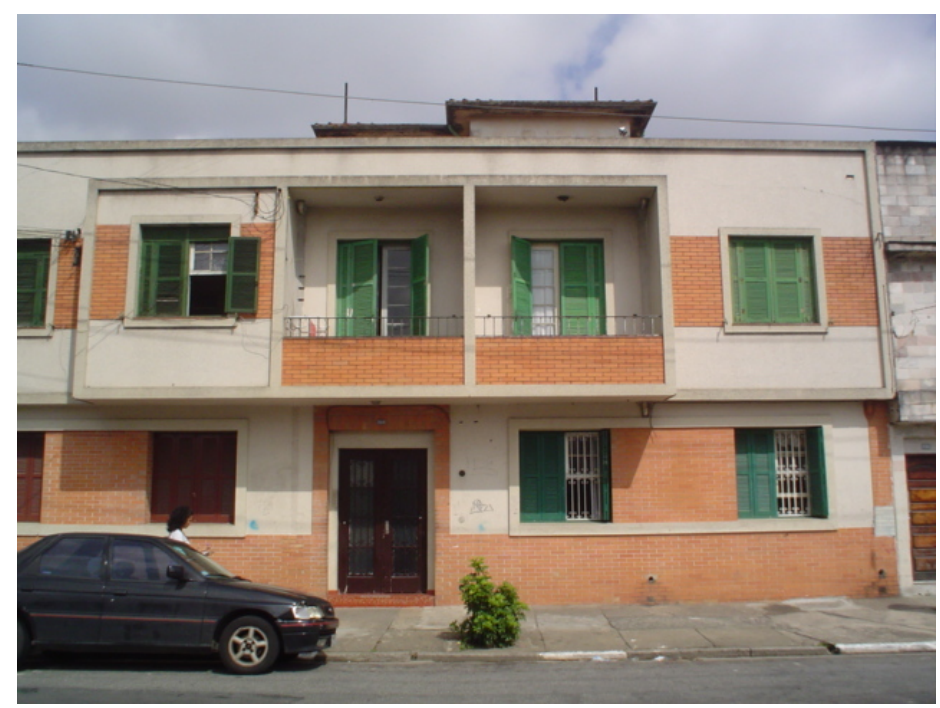

Foto 6 - Rua Ana Neri, 868.

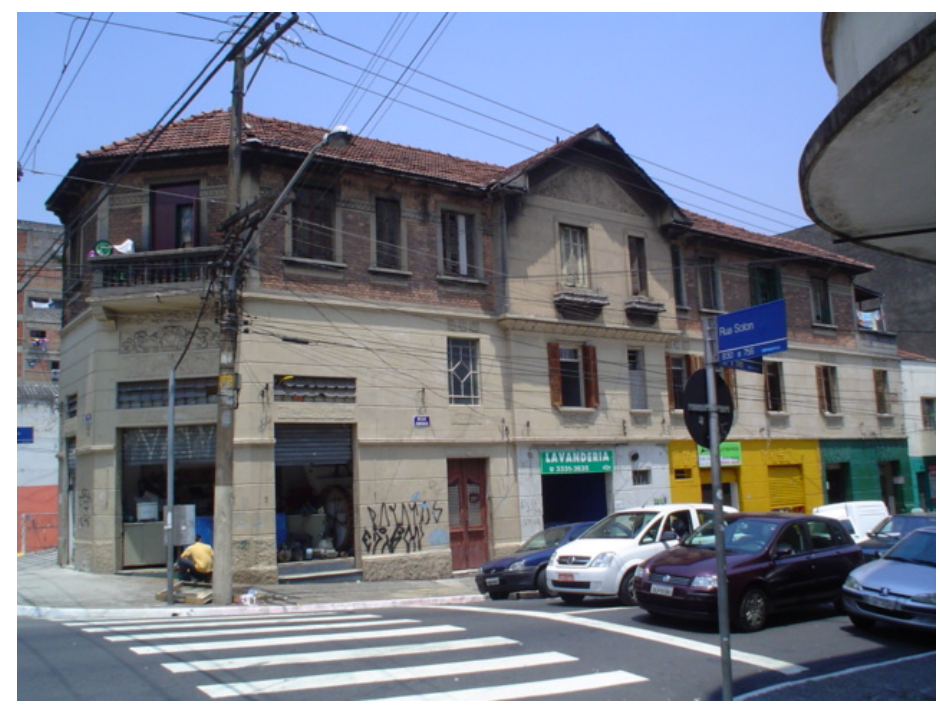

Foto 7 - Rua Anhaia, 549. 


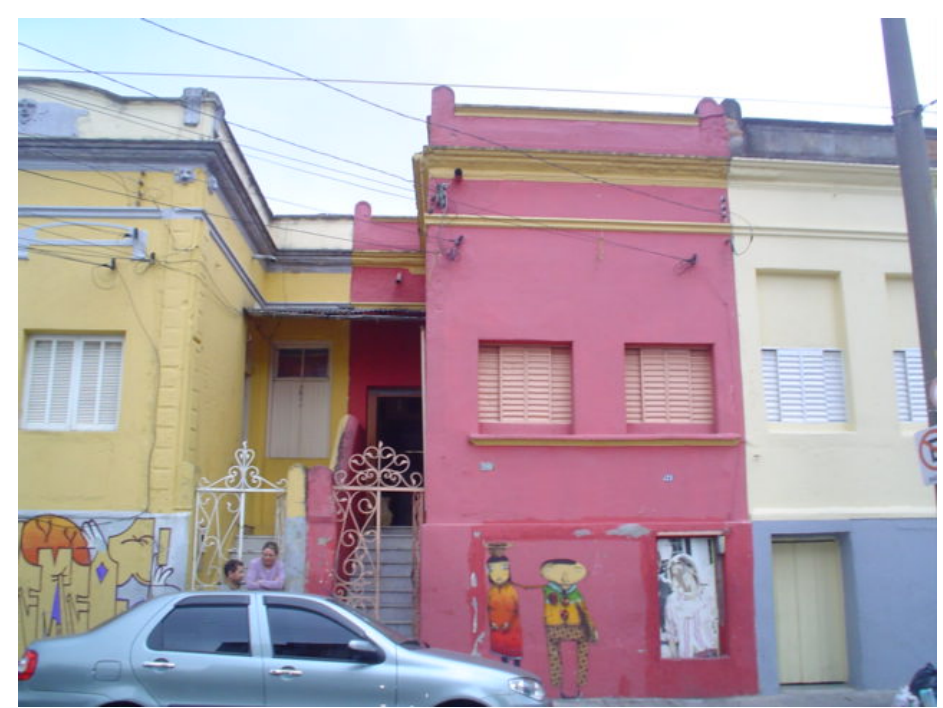

Foto 8 - Rua Barão de Jaguará, 769.

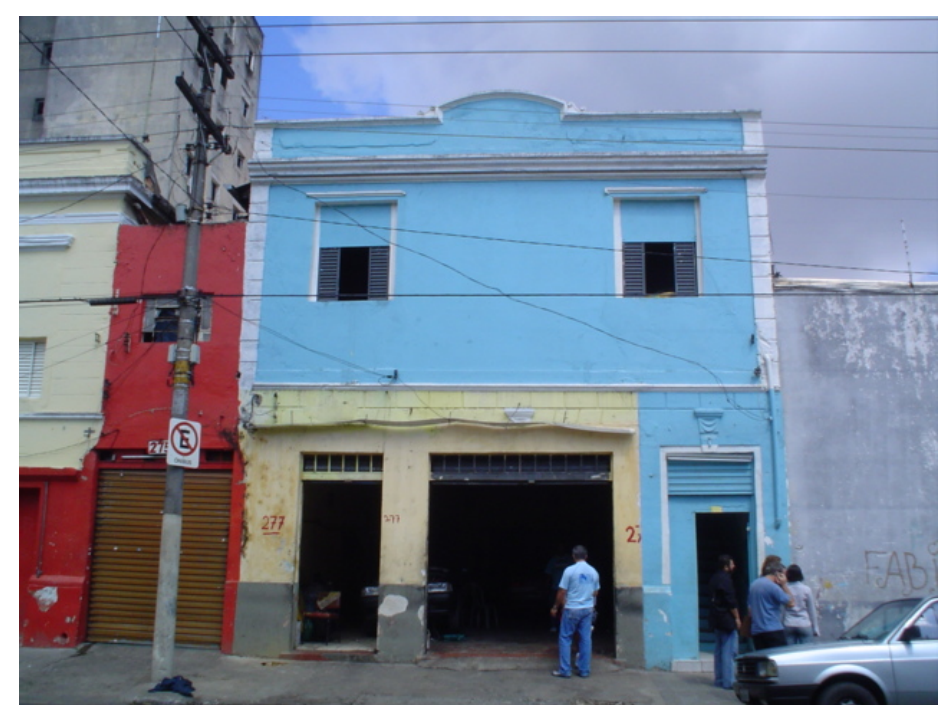

Foto 9 - Rua Barão de Piracicaba, 53.

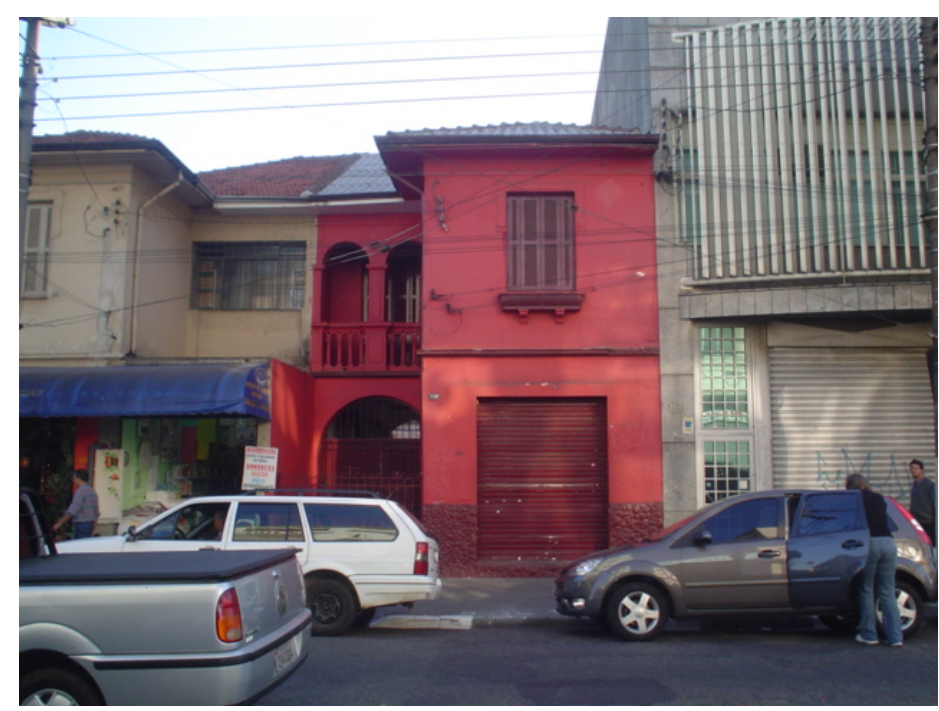

Foto 10 - Rua Bresser, 1190. 


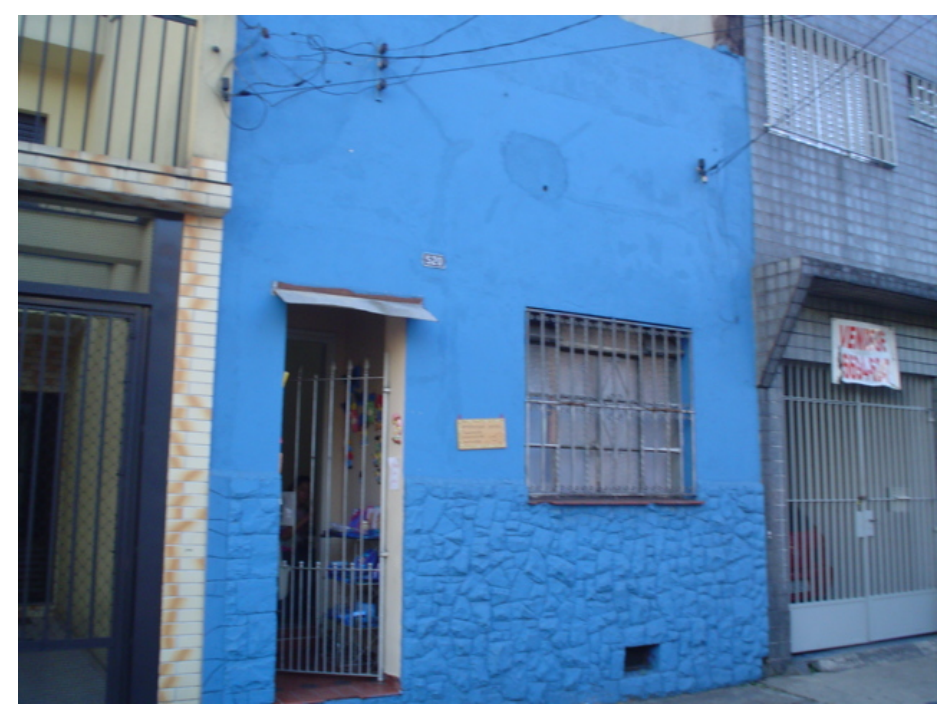

Foto 11 - Rua Cachoeira, 520.

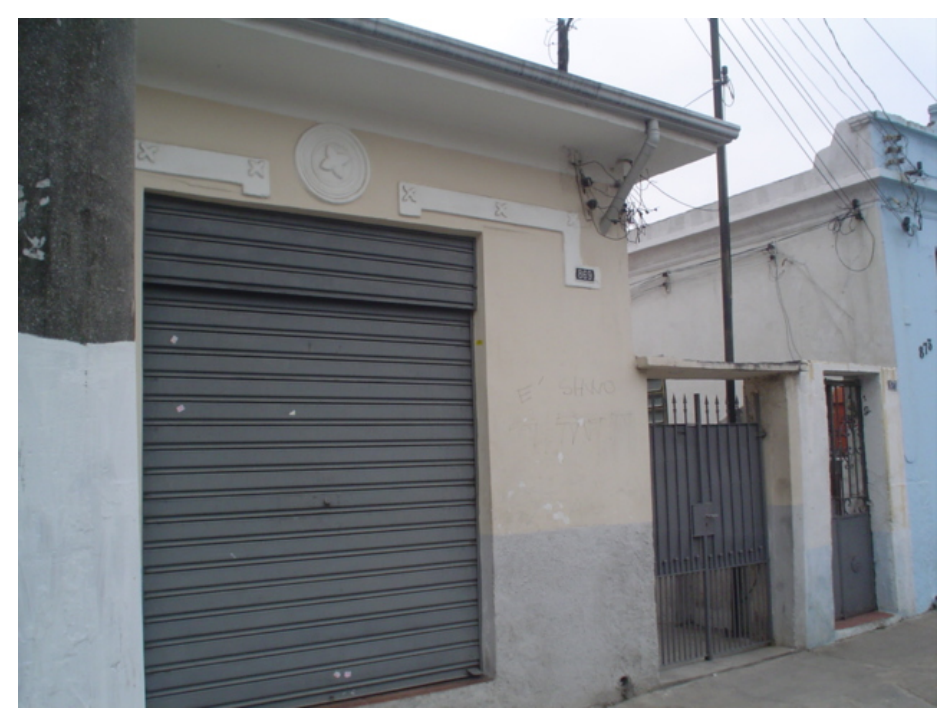

Foto 12 - Rua Cachoeira, 869.

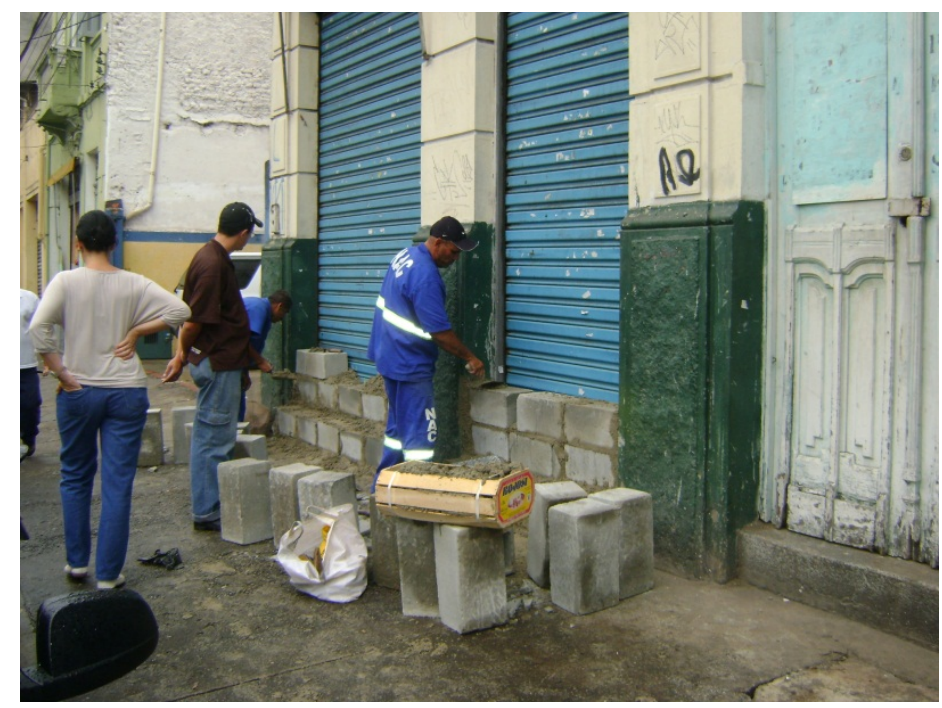

Foto 13 - Rua Caetano Pinto, 40. 


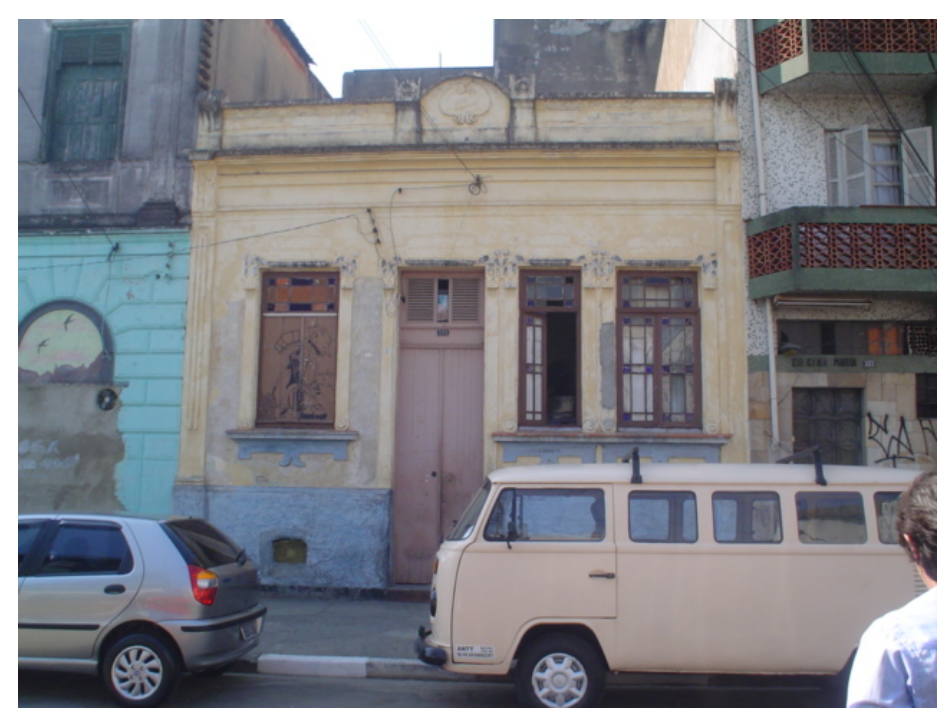

Foto 14 - Rua Caetano Pinto, 215.

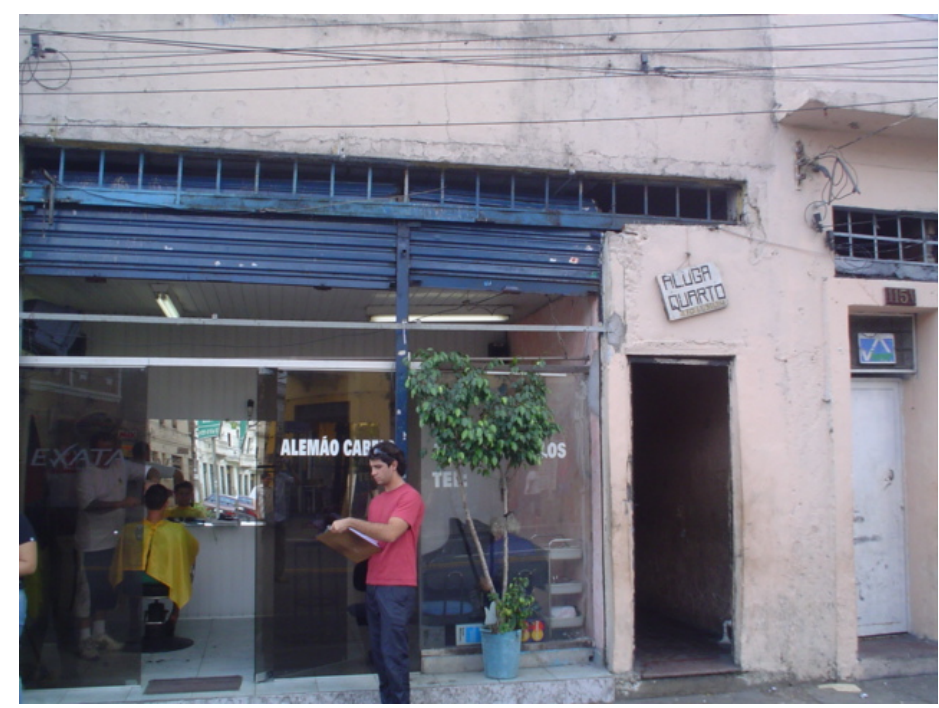

Foto 15 - Avenida Celso Garcia, 1147.

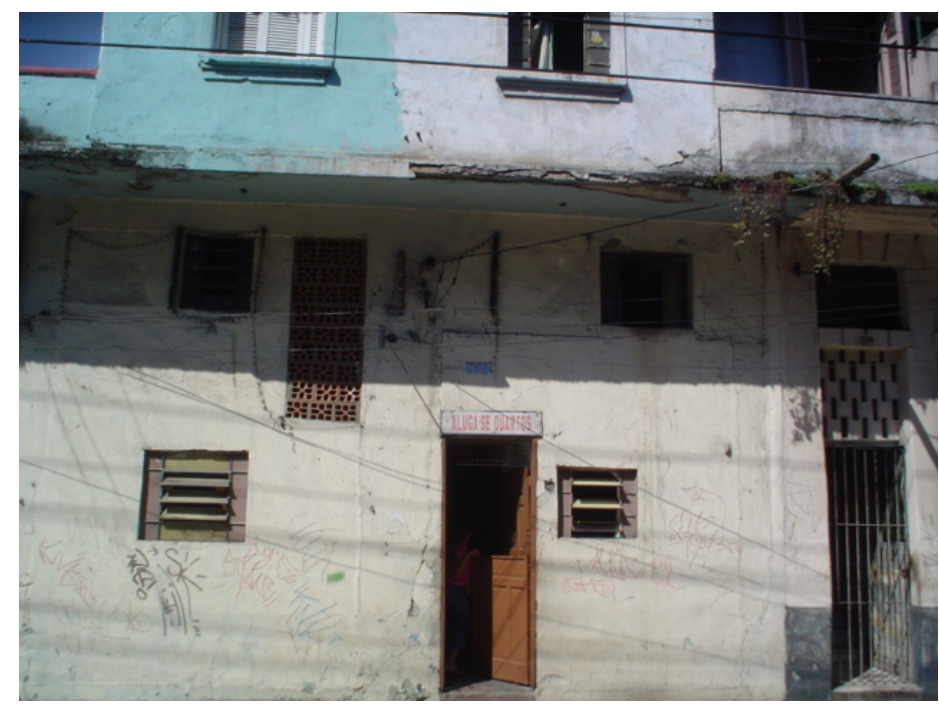

Foto 16 - Avenida Celso Garcia, 2602. 


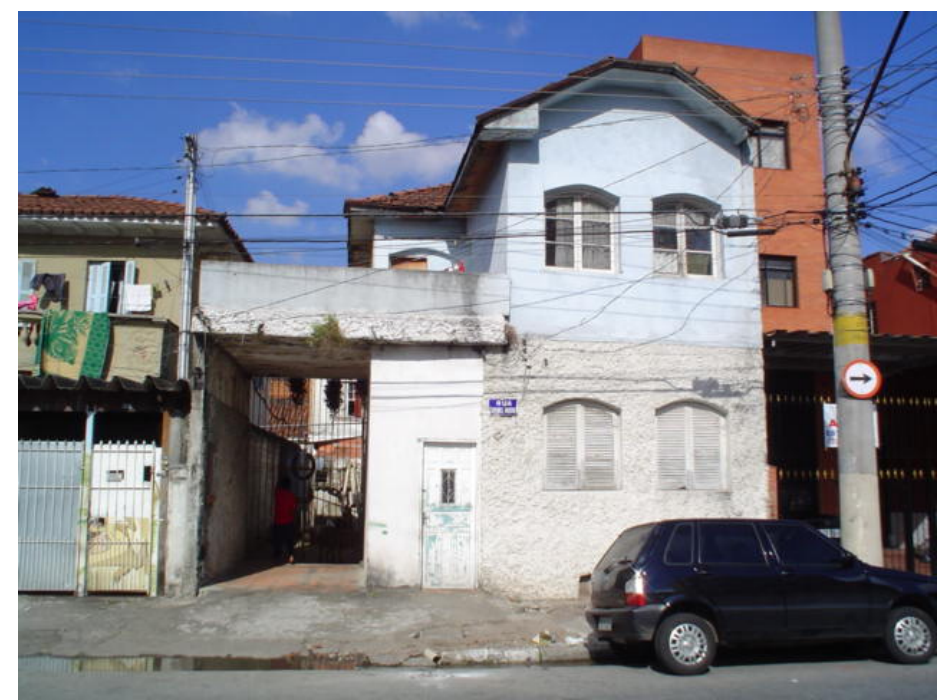

Foto 17 - Rua Coronel Morais, 294.

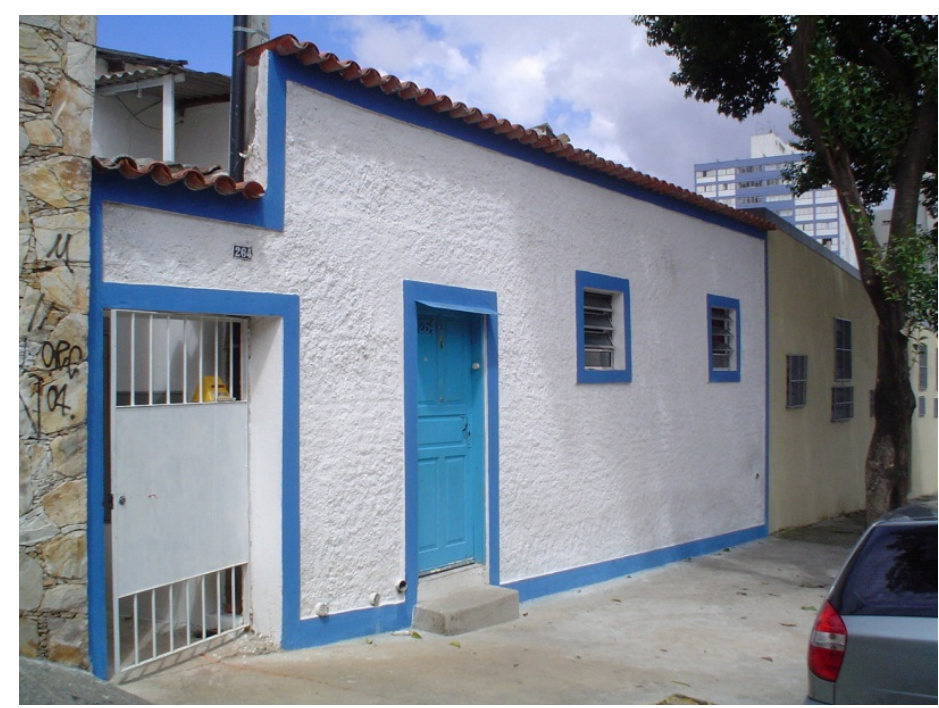

Foto 18 - Rua Curupacê, 264.

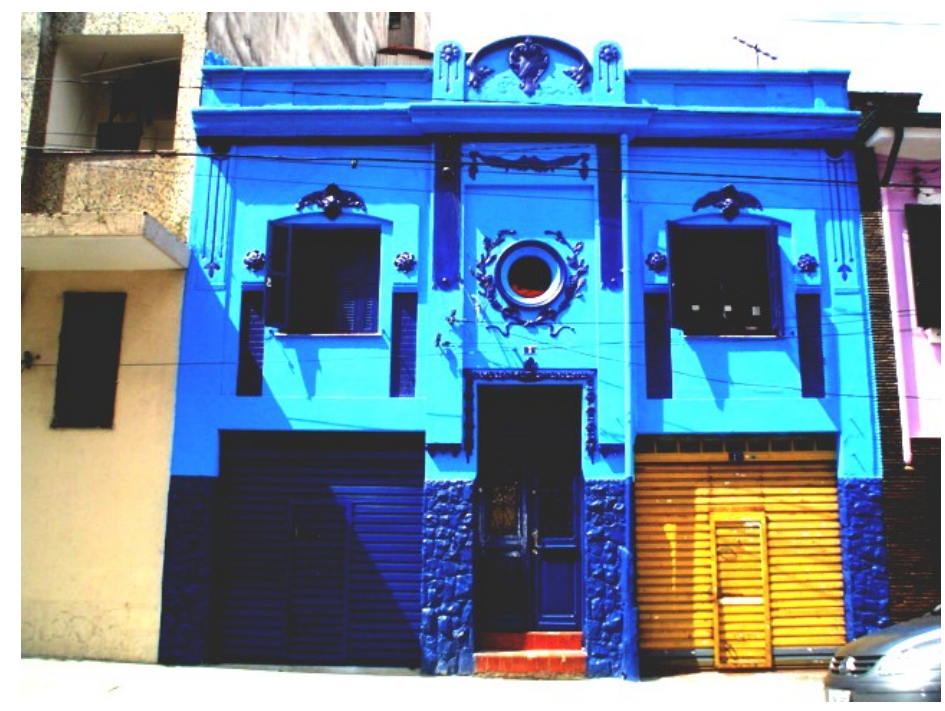

Foto 19 - Rua Francisco Sá Barbosa, 1. 


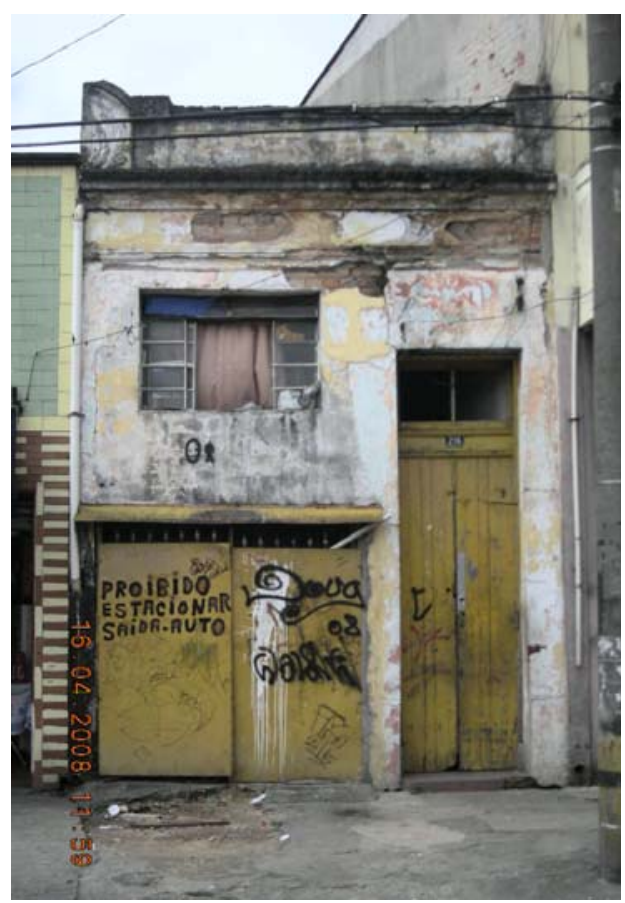

Foto 20 - Rua 21 de abril, 165.

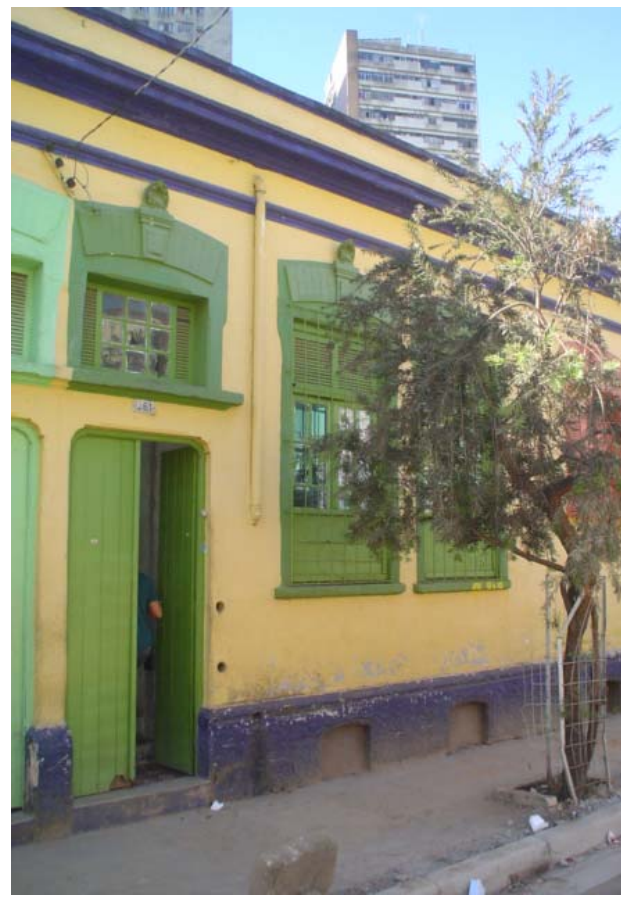

Foto 22 - Rua dos Estudantes, 561.

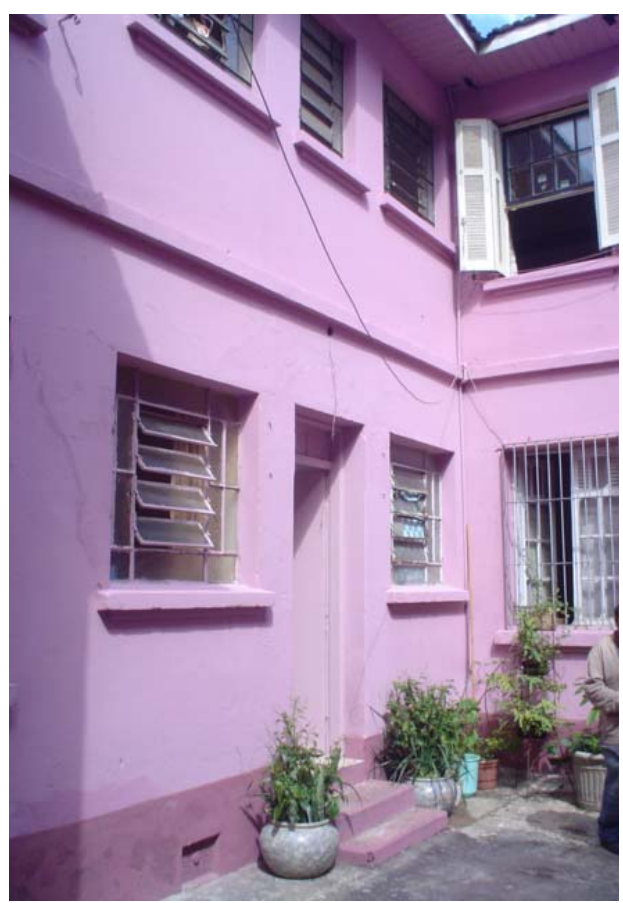

Foto 21 - Rua Dino Bueno, 580.

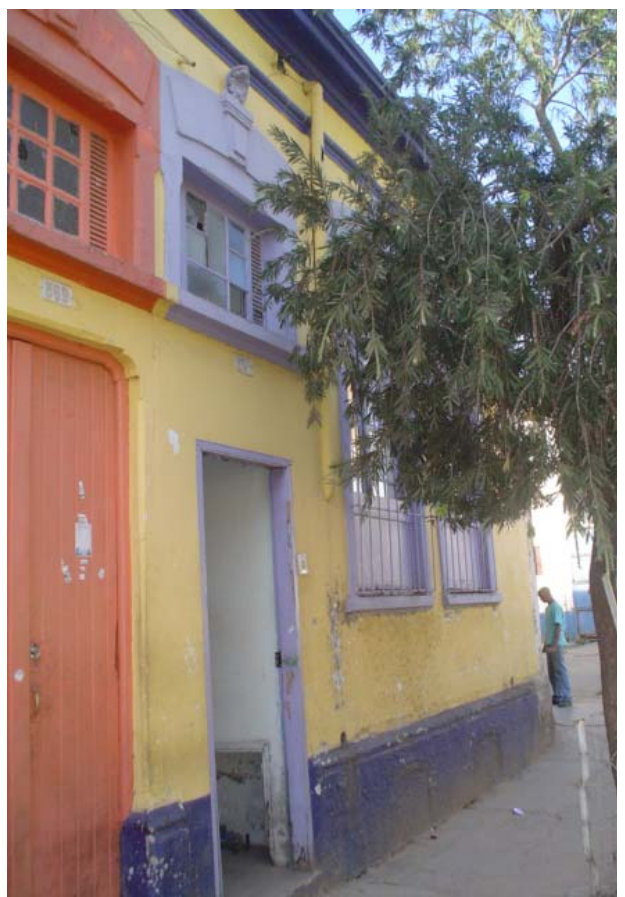

Foto 23 - Rua dos Estudantes, 571. 


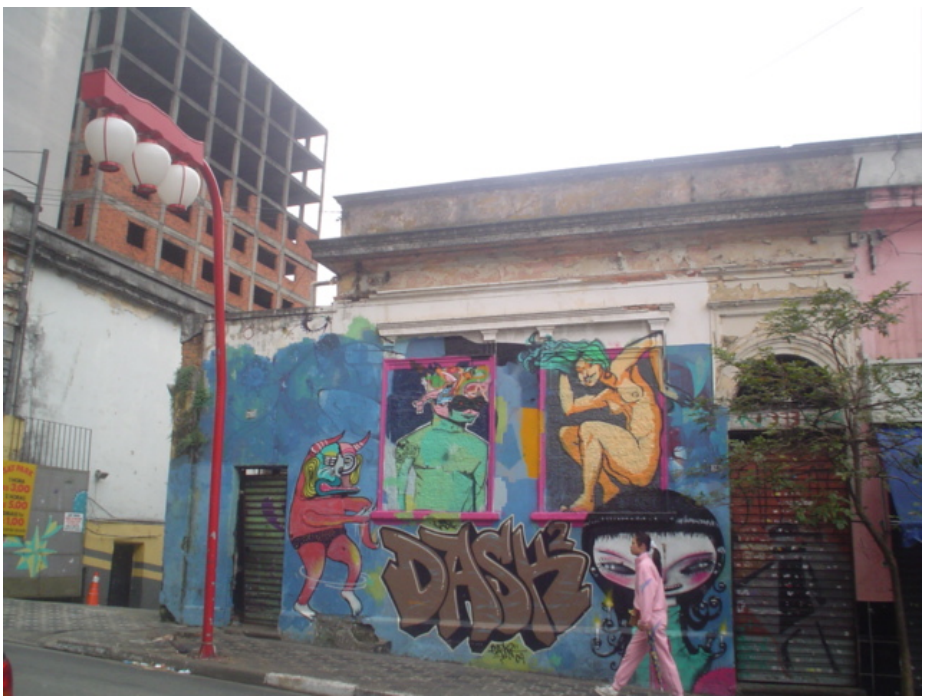

Foto 24 - Rua Galvão Bueno, 365.

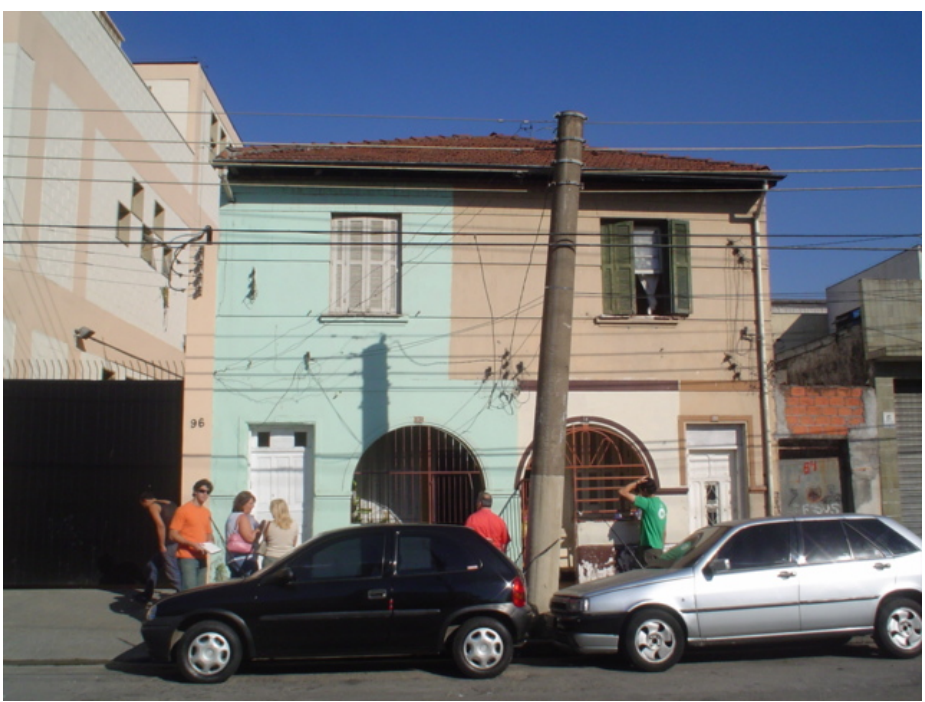

Foto 25 - Rua João Alves, 94.

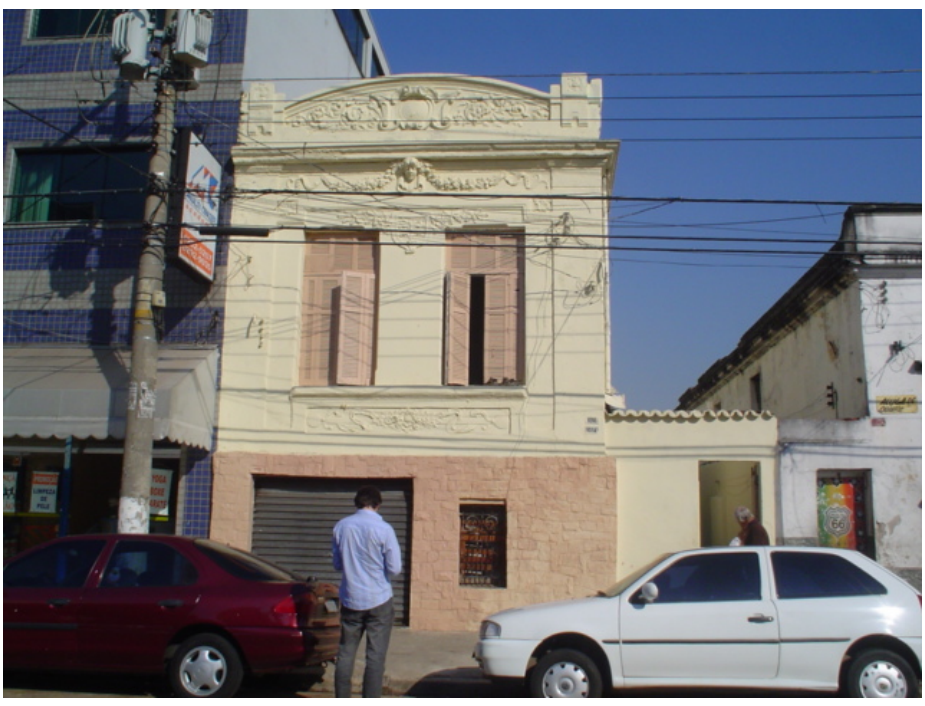

Foto 26 - Rua Julho Castilho, 1014. 


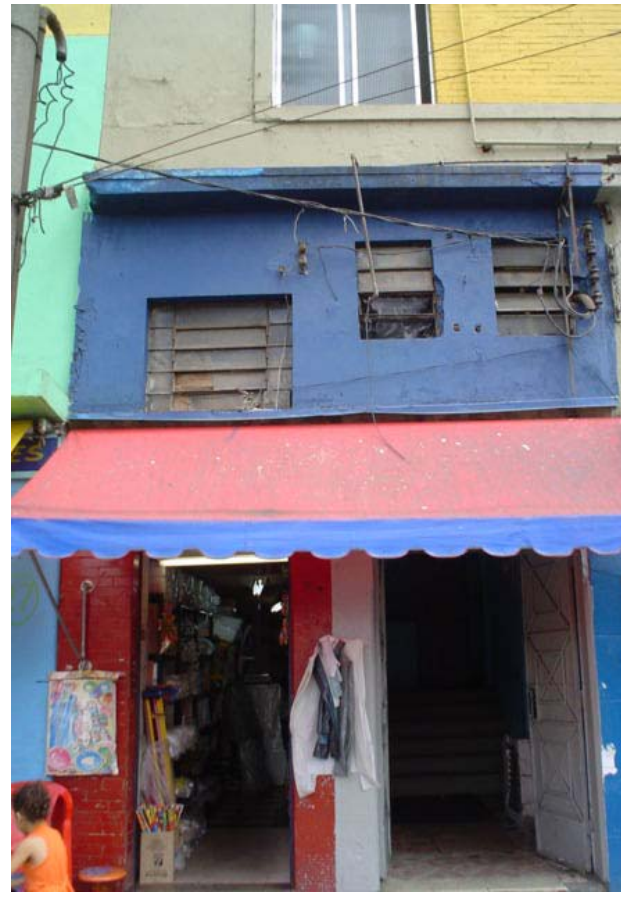

Foto 27 - Largo da Concórdia, 35.

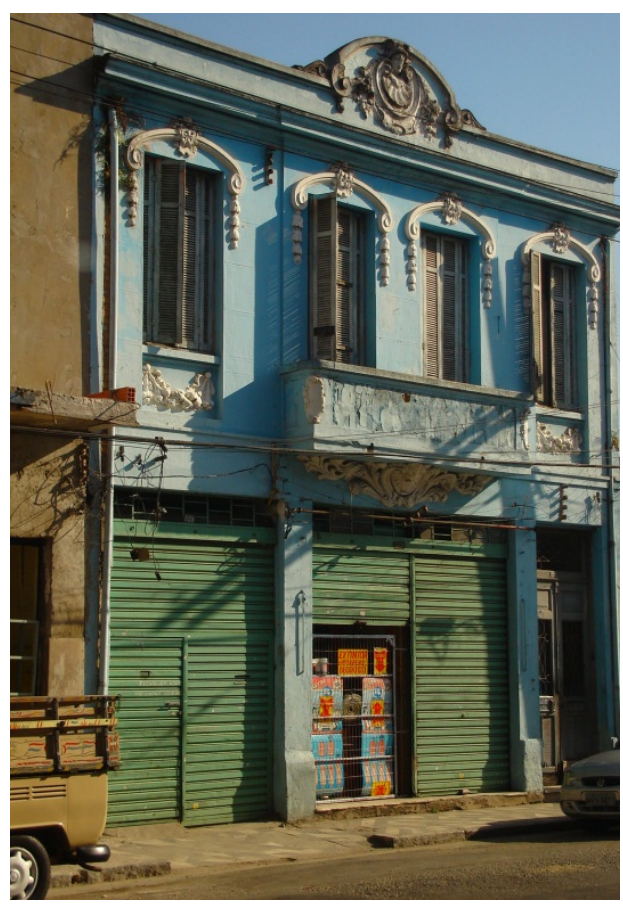

Foto 29 - Rua São Caetano, 828.

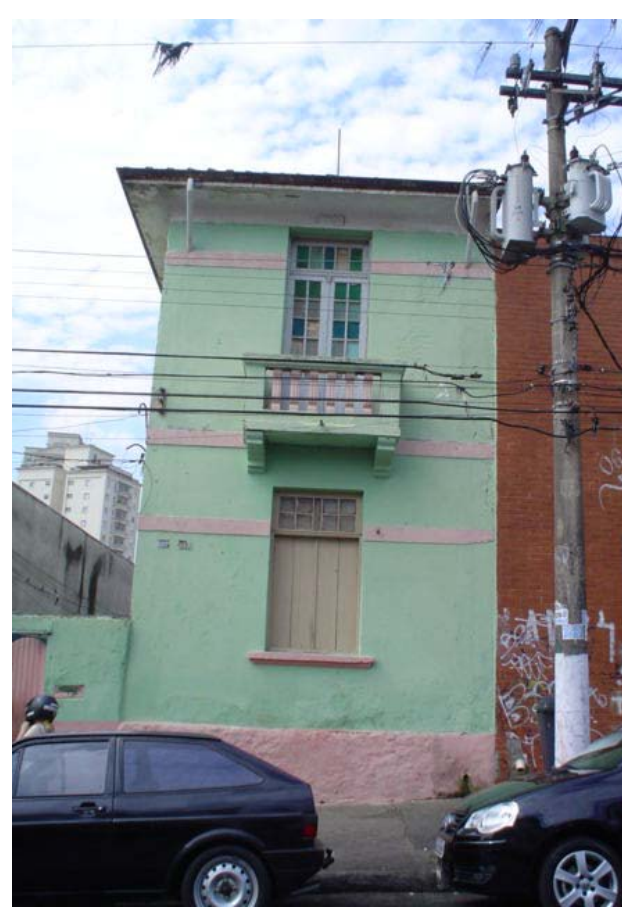

Foto 28 - Rua Madredeus, 663. 


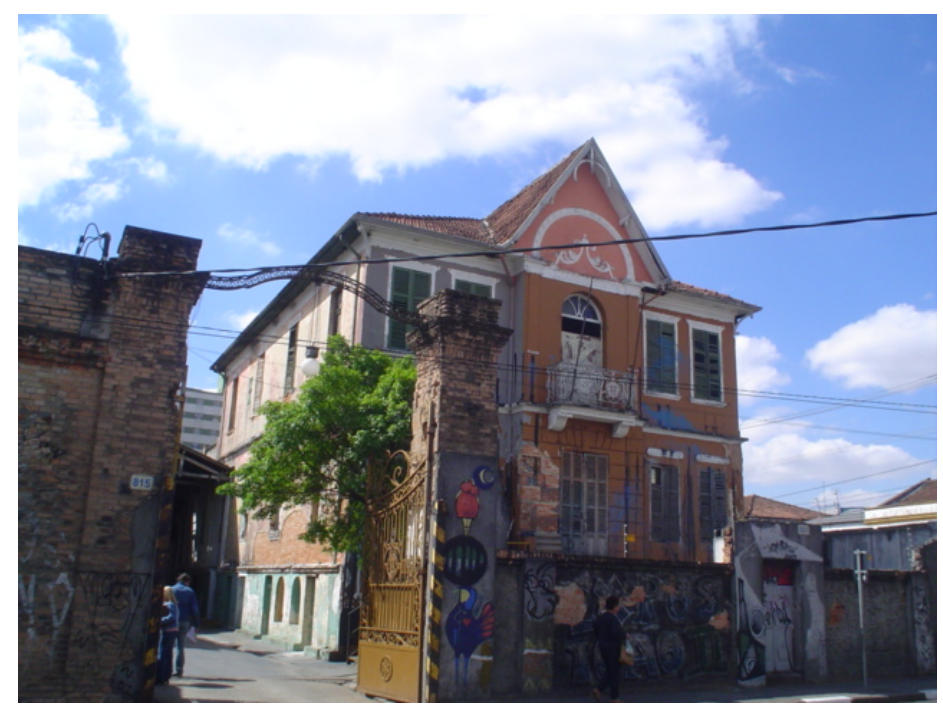

Foto 30 - Rua da Mooca, 699.

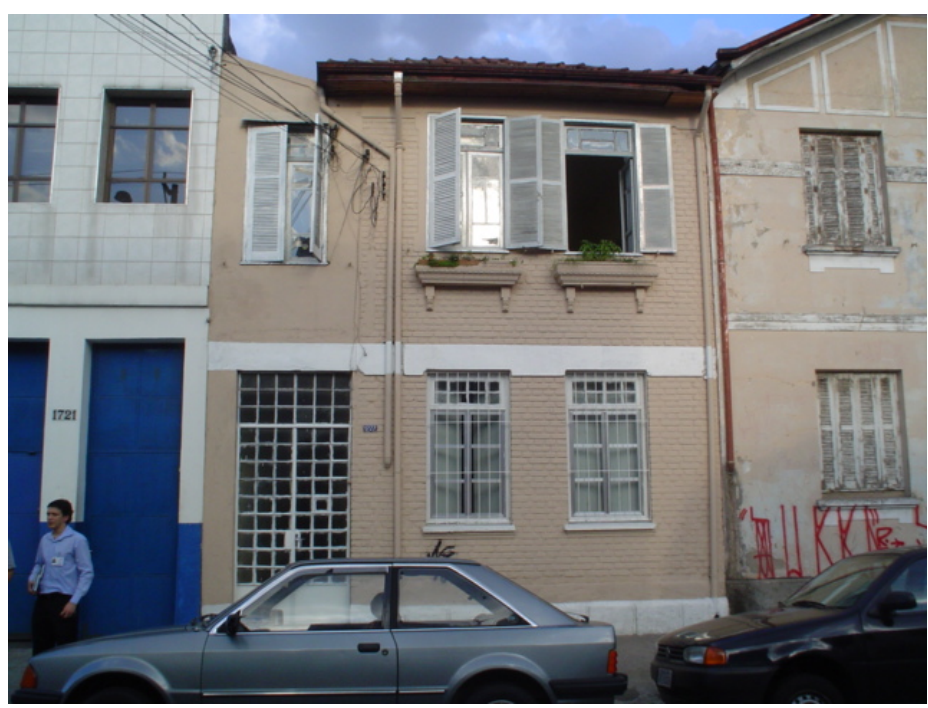

Foto 31 - Rua Rio Bonito, 1727.

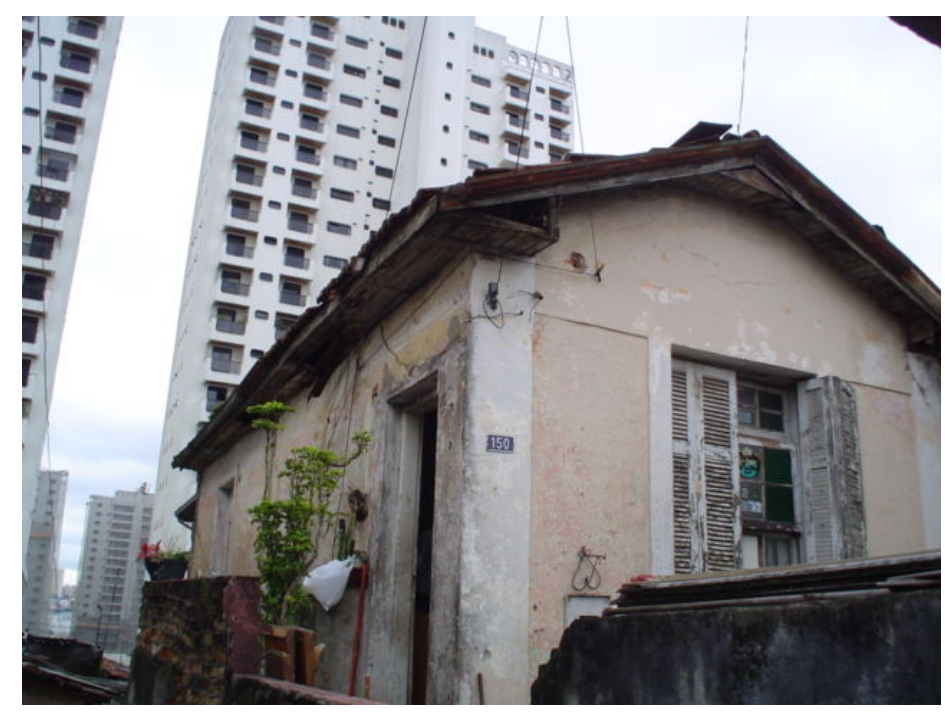

Foto 32 - Rua Tabajaras, 150. 
ANEXO E - Fotografias realizadas em "Vistorias Prévias" de imóveis encortiçados - Áreas de uso comum.

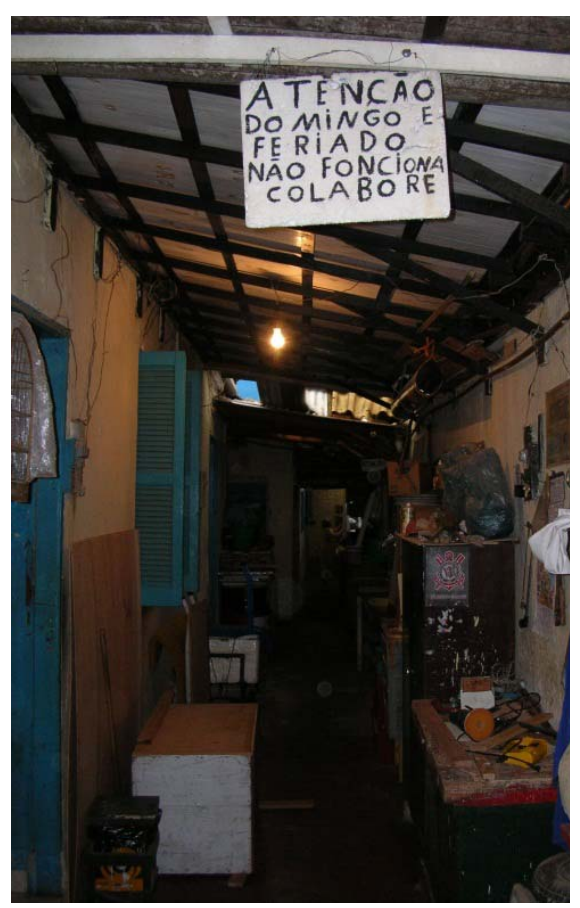

Foto 33 - Rua Gomes Cardim, 94.

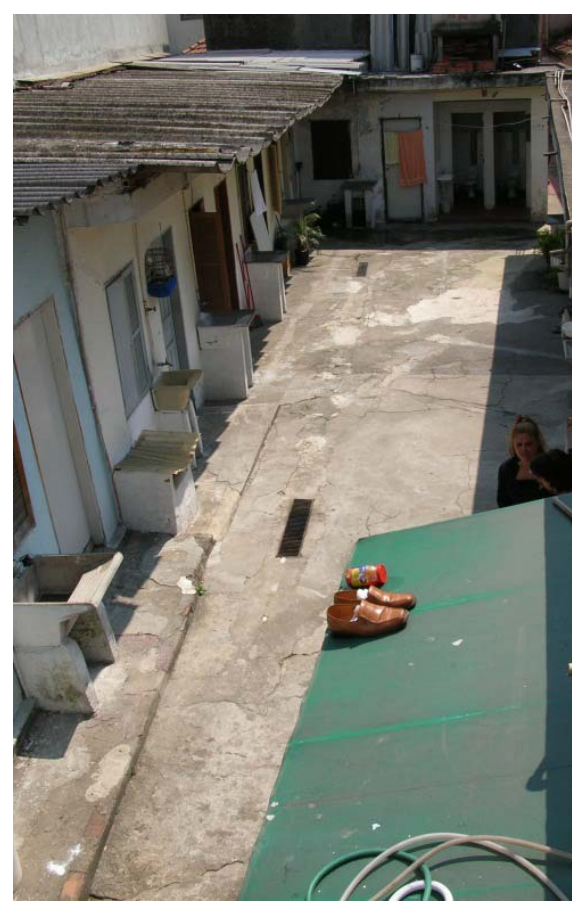

Foto 35 - Rua Julho de Castilho, 578.

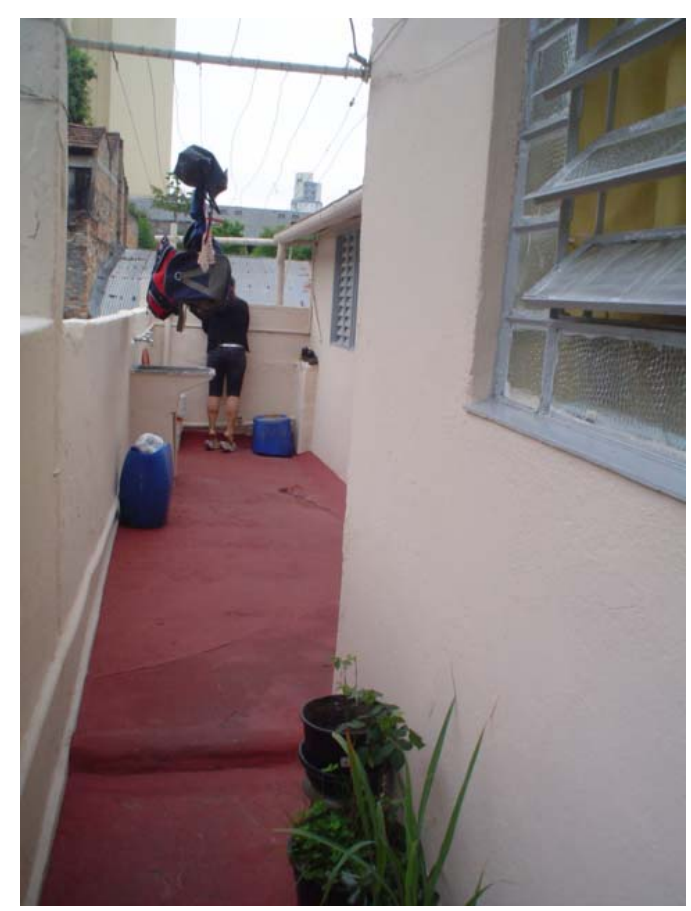

Foto 34 - Rua Ana Neri, 1256.

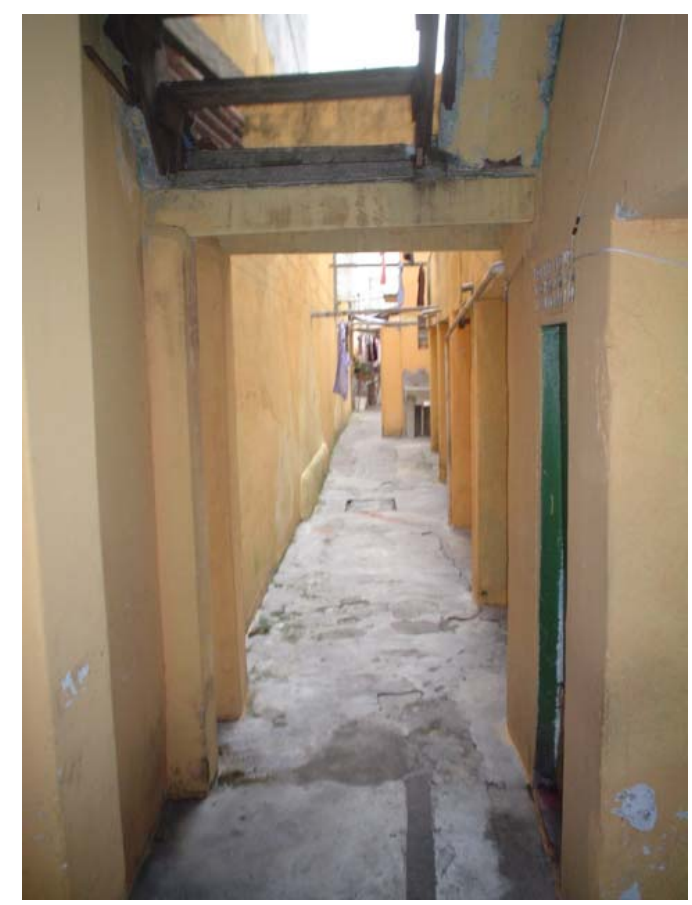

Foto 36 - Rua Apa, 31. 


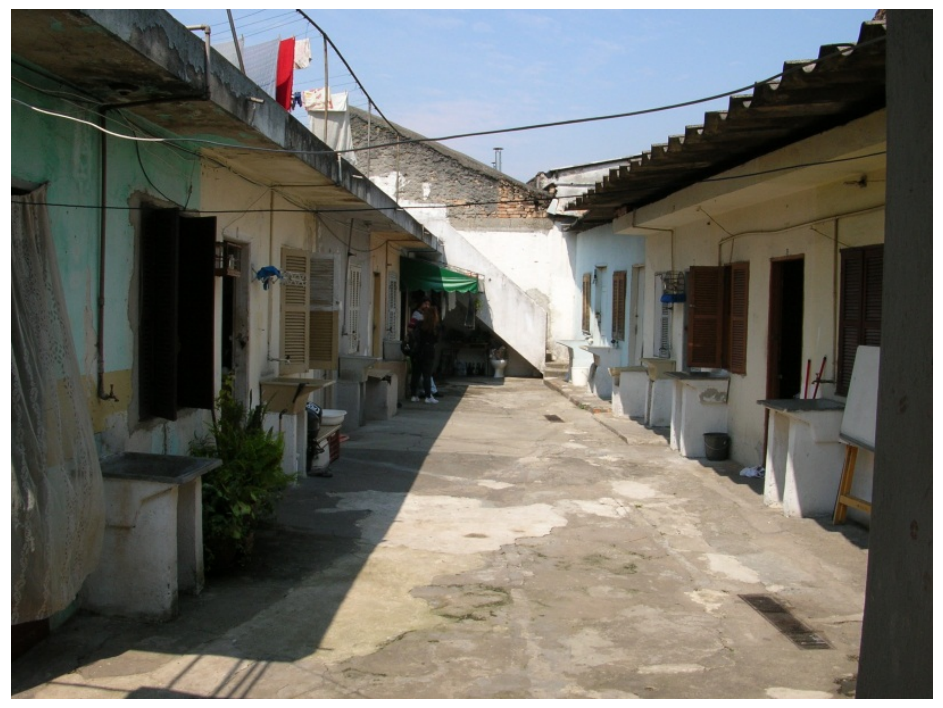

Foto 37 - Rua Julho de Castilho, 578.

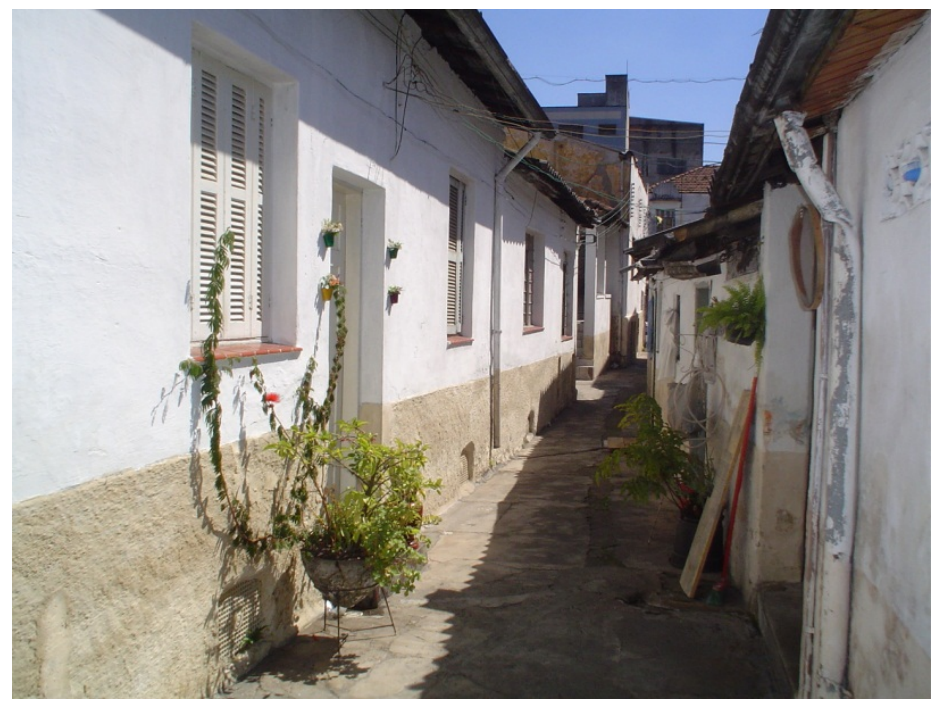

Foto 38 - Rua Carnot, 456.

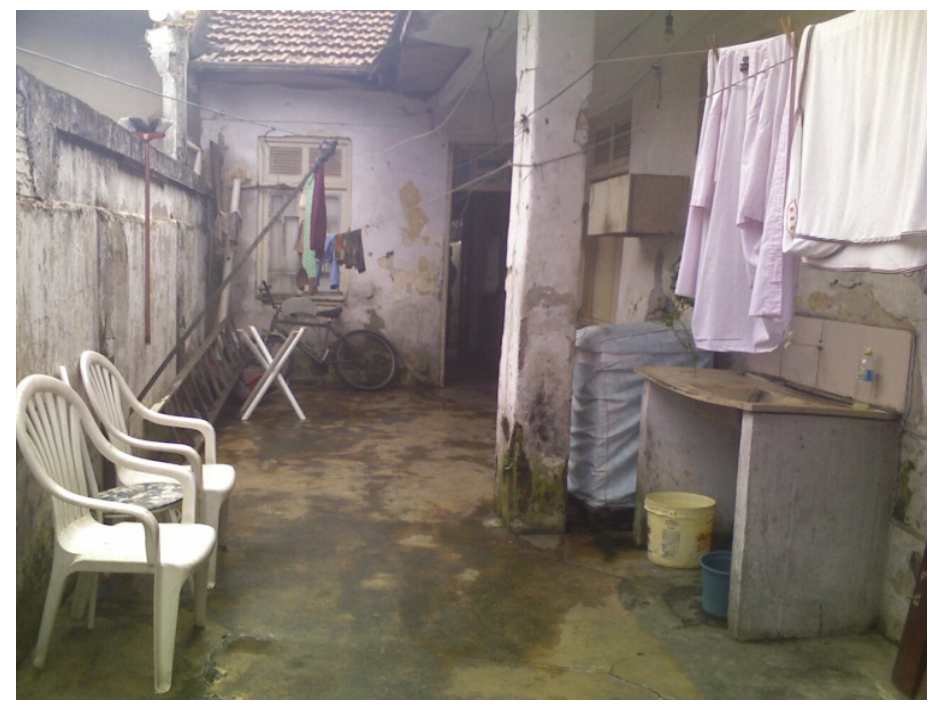

Foto 39 - Rua Artur Mota, 203. 


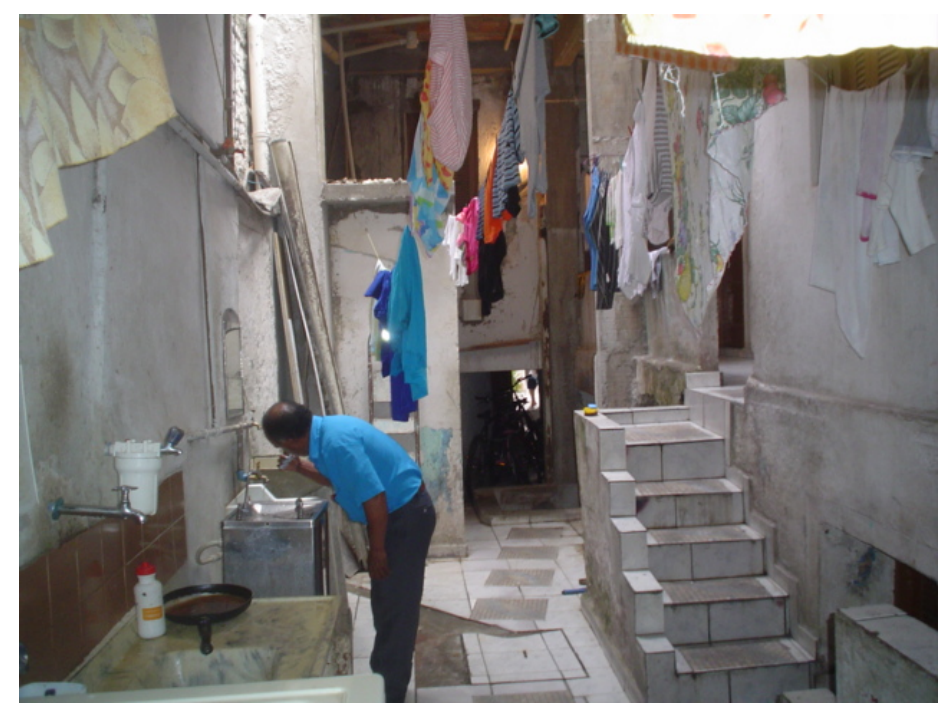

Foto 40 - Rua Dr. Clementino, 582.

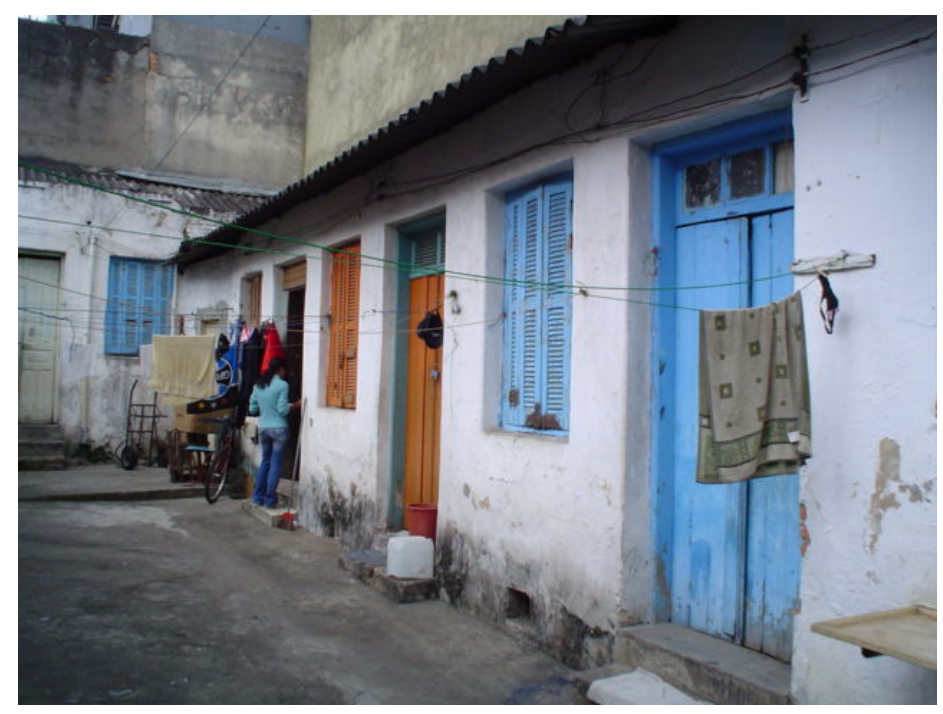

Foto 41 - Rua Almeida Lima, 115.

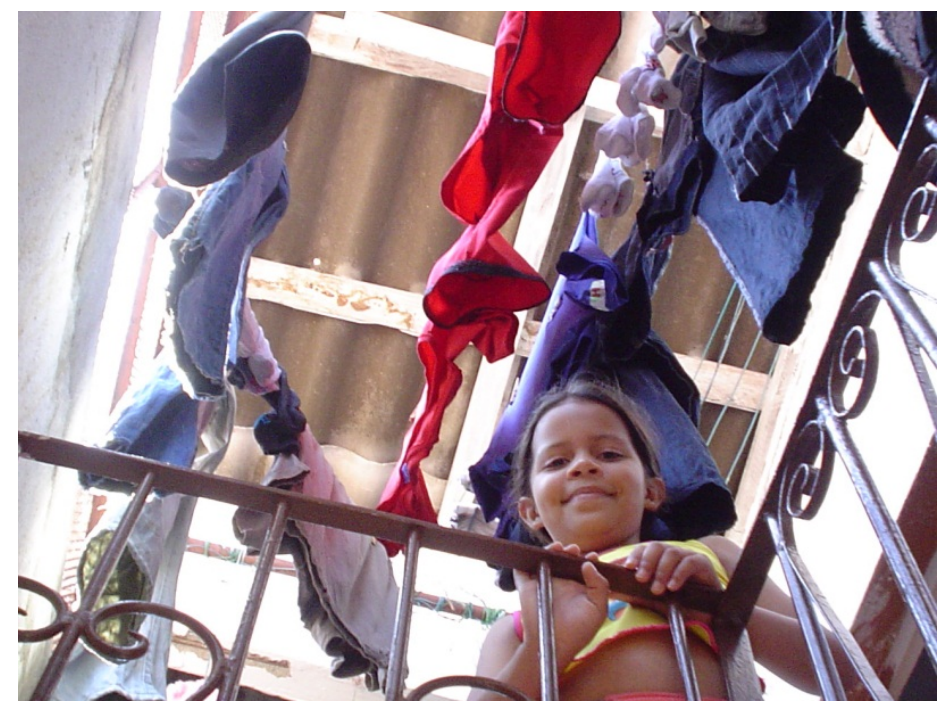

Foto 42 - Rua Almeida Lima, 413. 


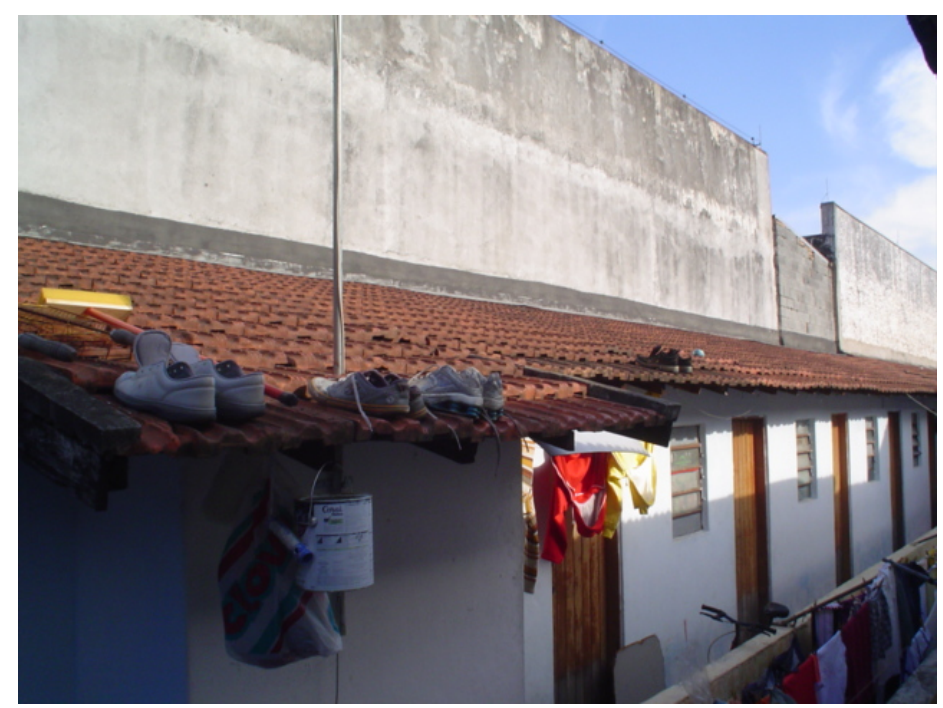

Foto 43 - Rua Almeida Lima, 341

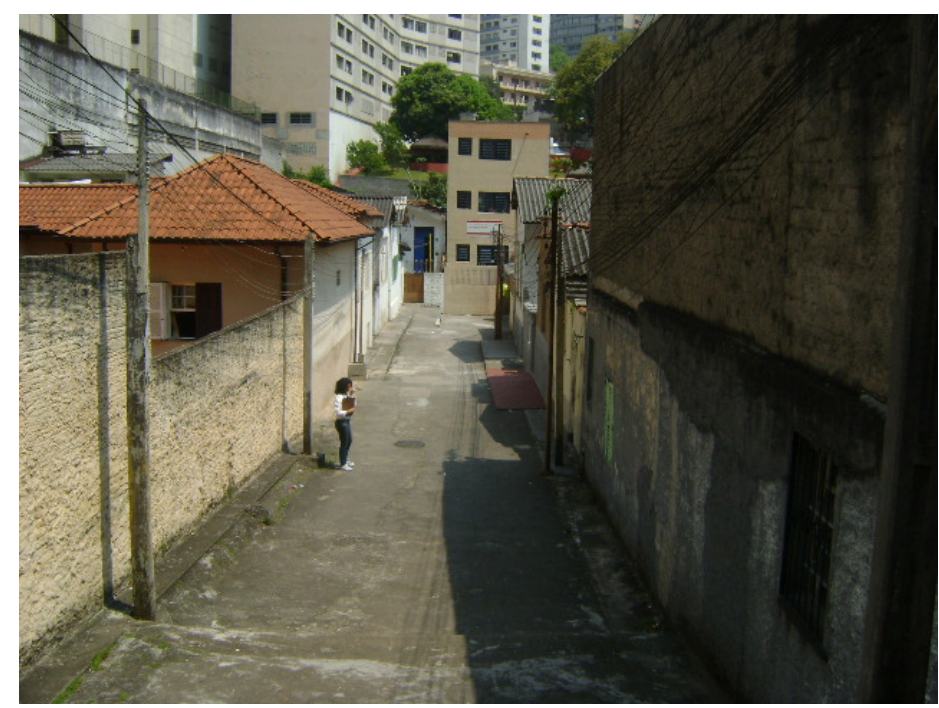

Foto 44 - Rua Almirante Marques Leão, 602.

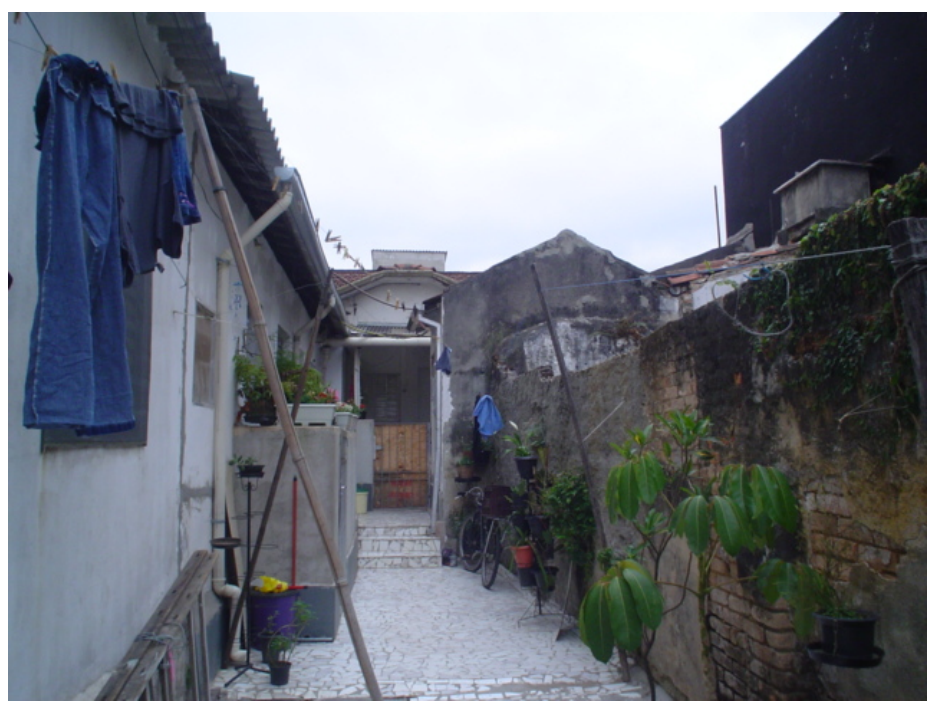

Foto 45 - Rua Almirante Barroso, 733. 


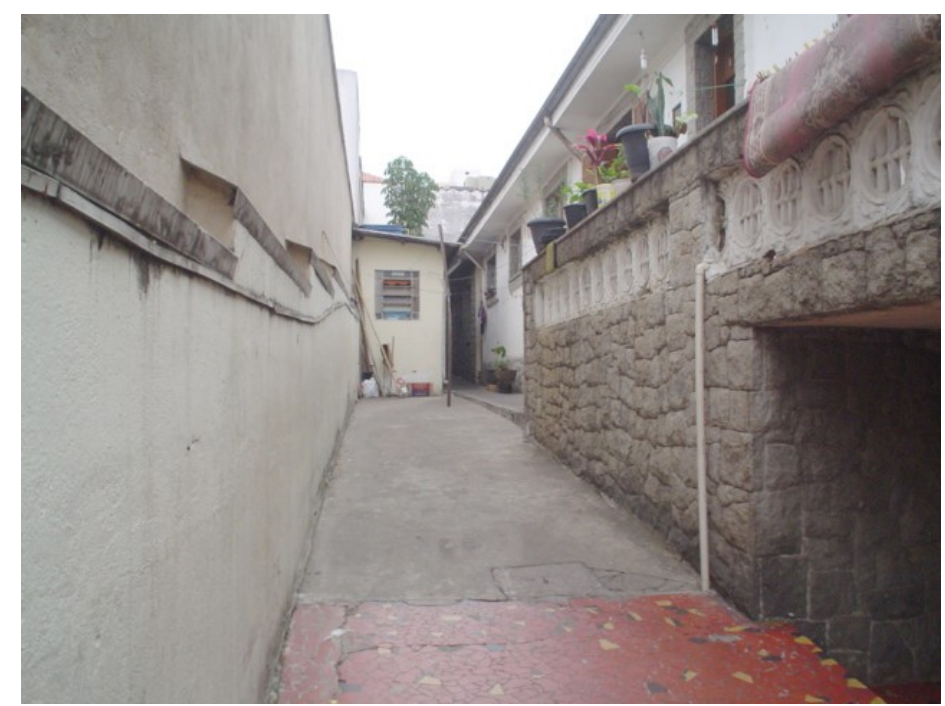

Foto 46 - Rua Arinaia, 424.

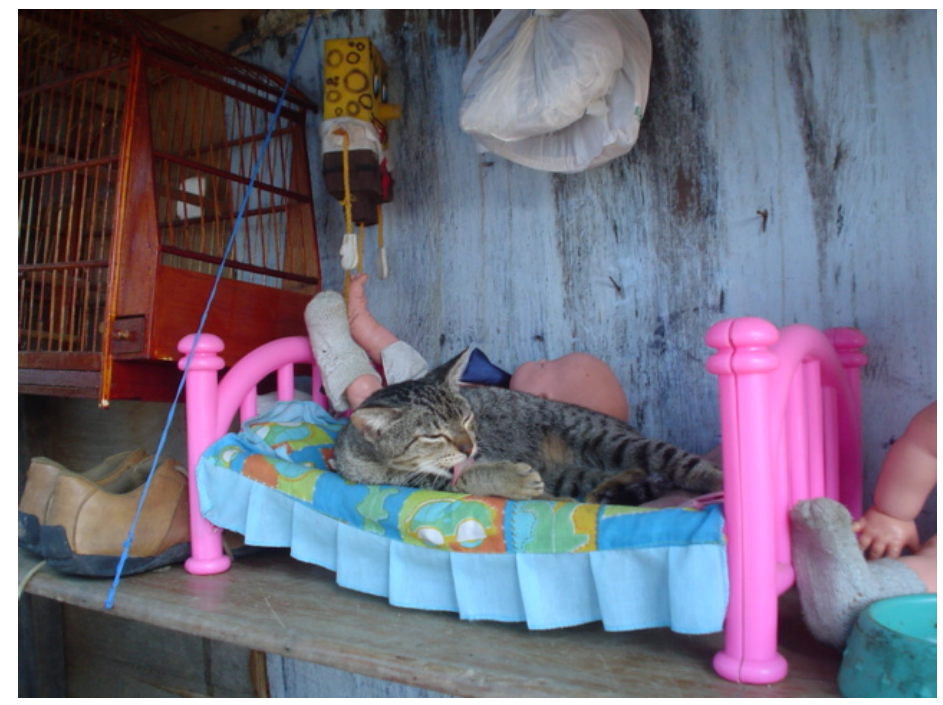

Foto 47 - Avenida Celso Garcia, 1710.

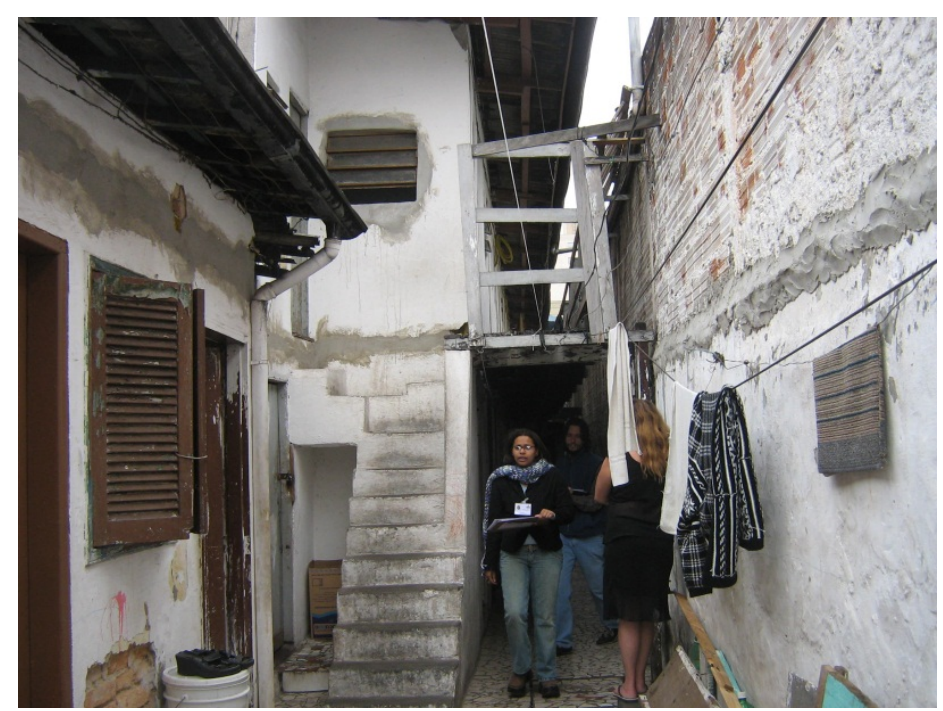

Foto 48 - Rua Celso Antônio Machado, 61. 


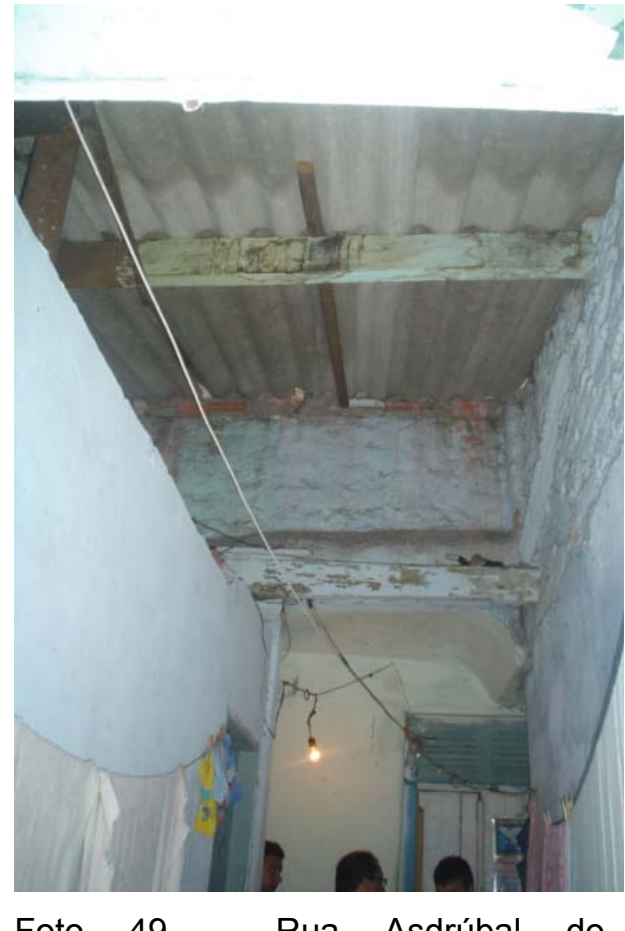

Foto 49 - Rua Asdrúbal do Nascimento, 160.

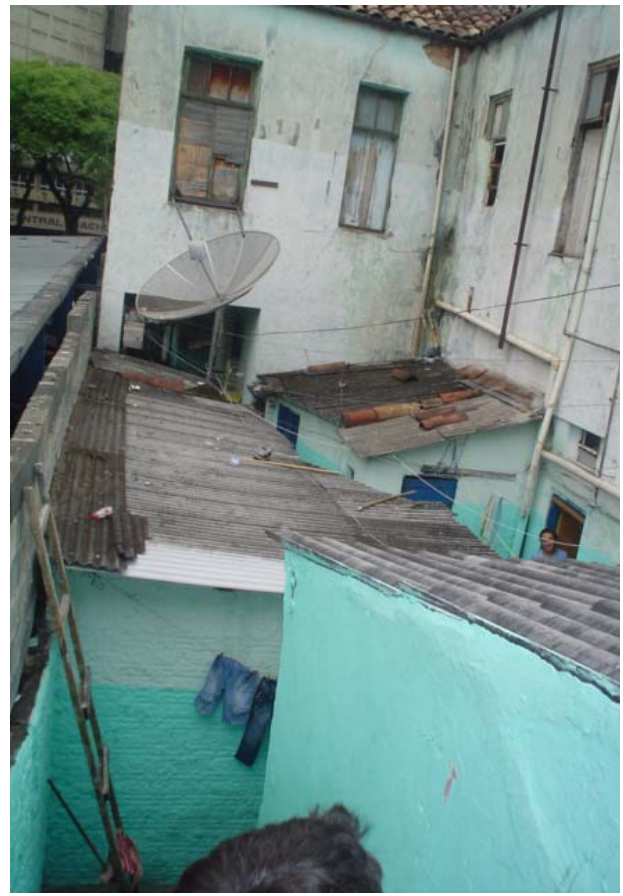

Foto 51 - Rua Asdrúbal do Nascimento, 160.

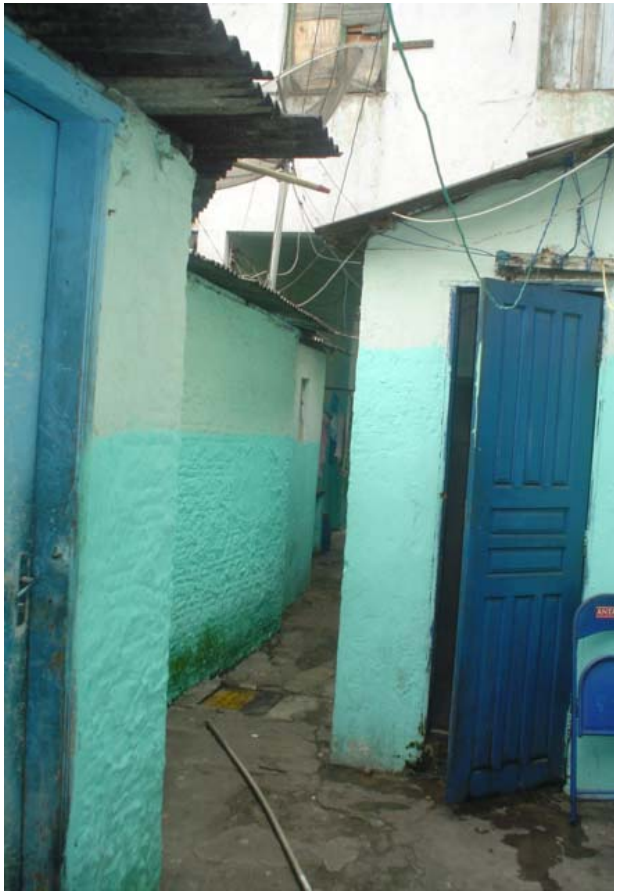

Foto 50 - Rua Asdrúbal do Nascimento, 160.

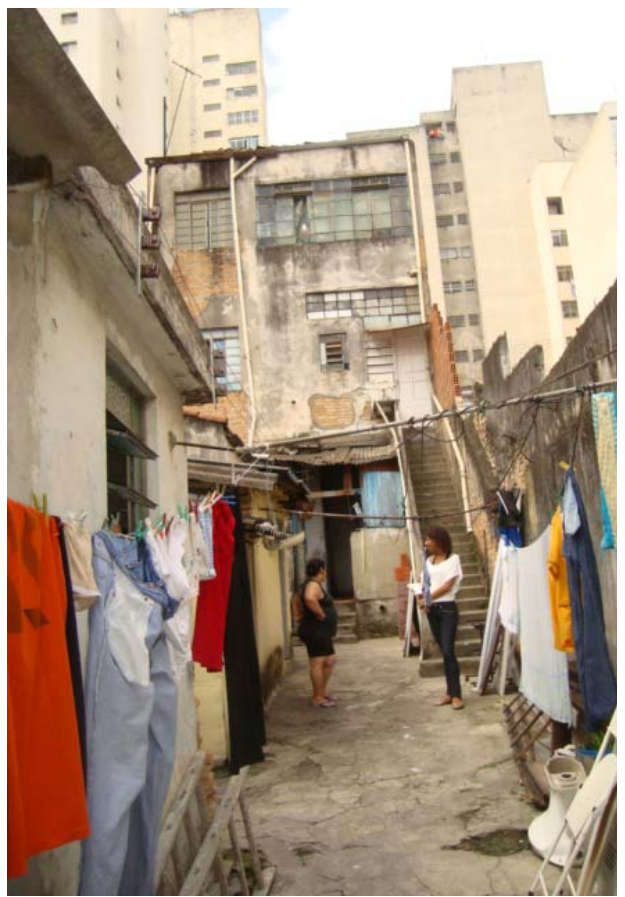

Foto 52 - Rua Bandeirantes, 290. 


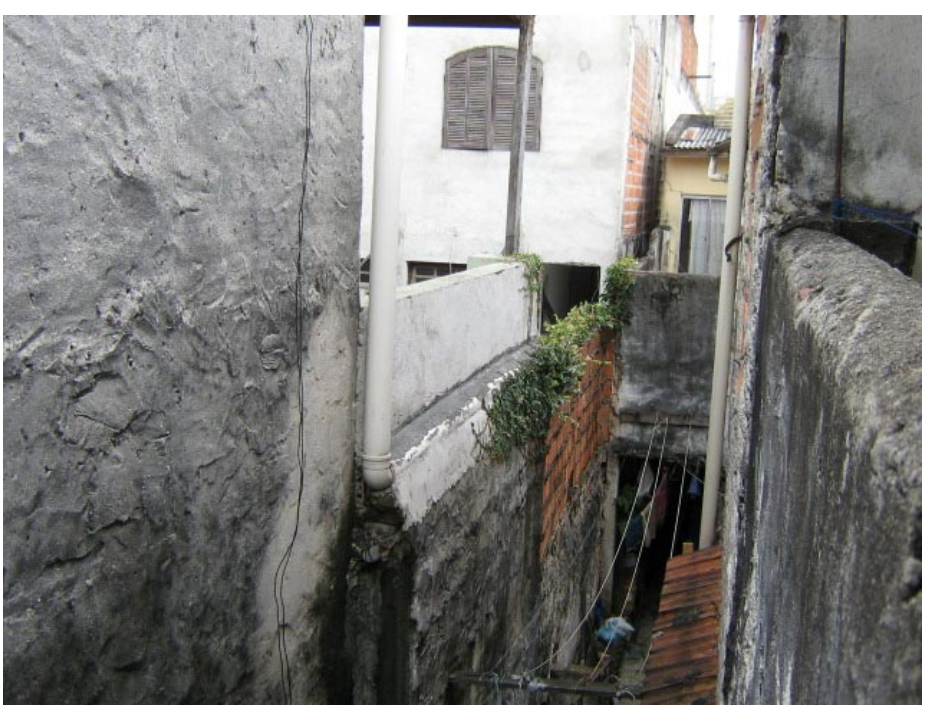

Foto 53 - Rua Belo Horizonte, 43.

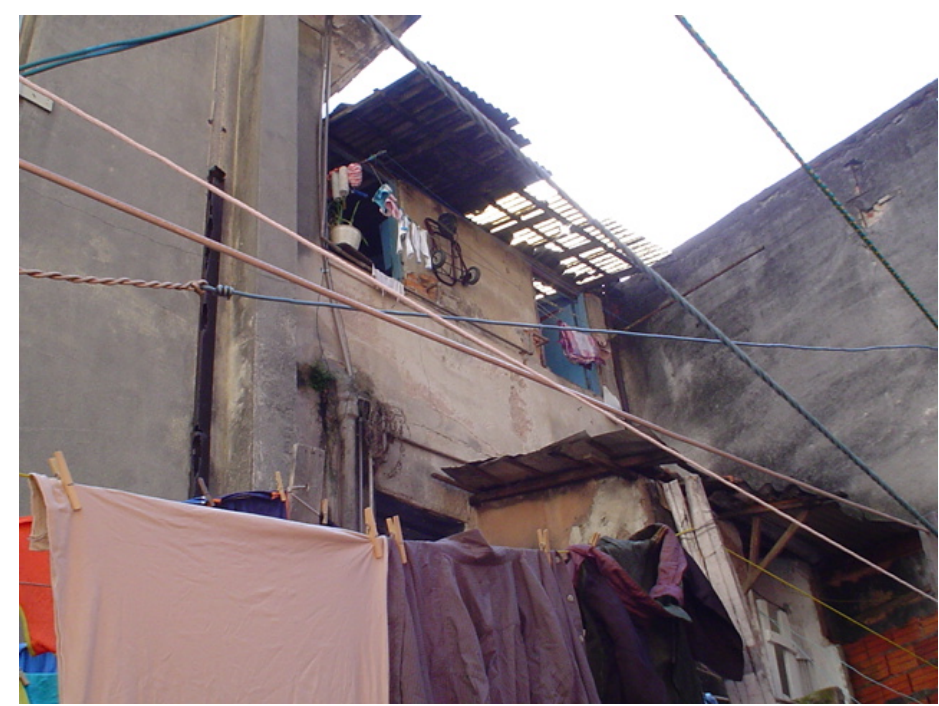

Foto 54 - Rua Augusta, 509.

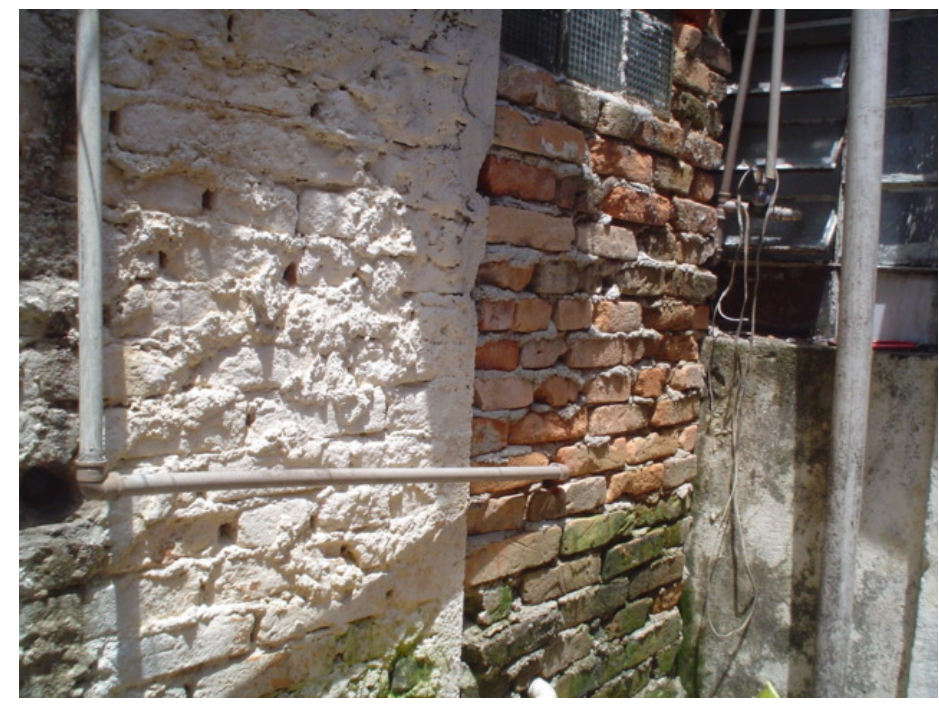

Foto 55 - Rua Barão de Jaguará, 744. 


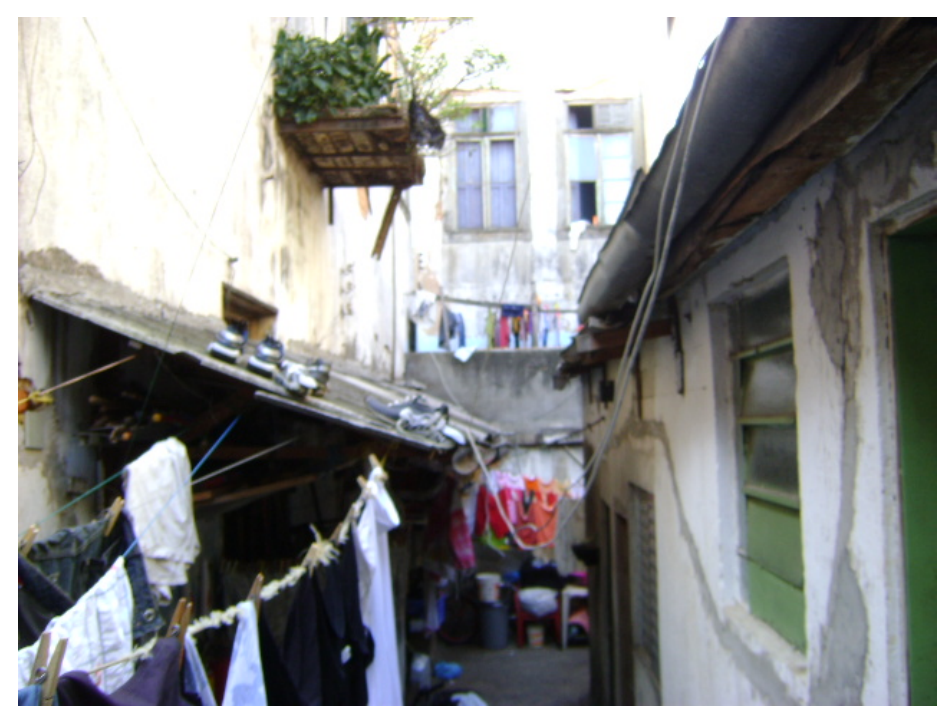

Foto 56 - Rua Barão de Piracicaba, 65.

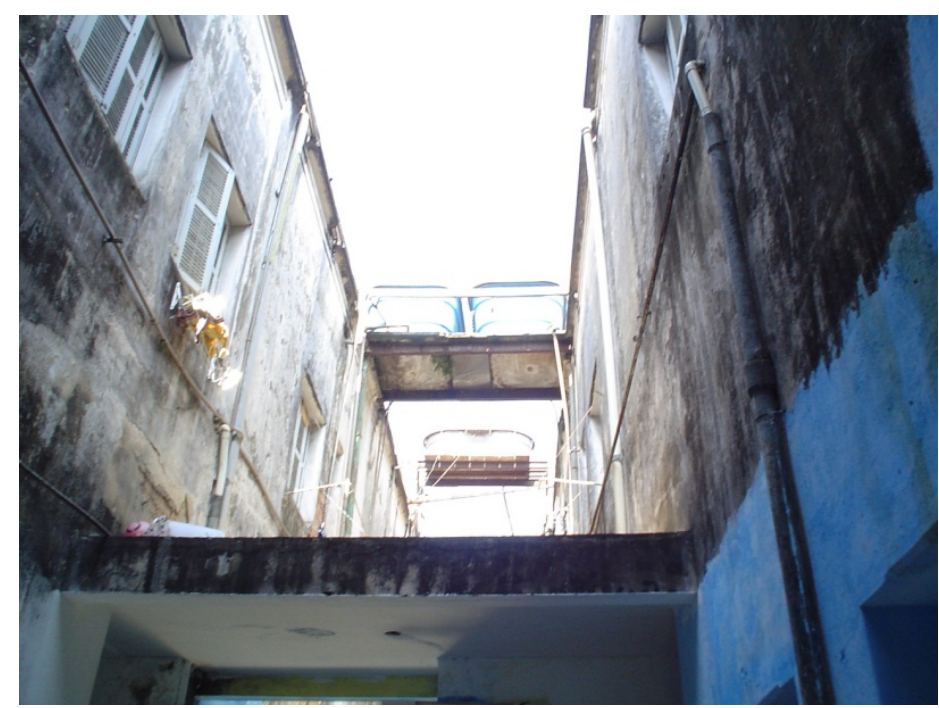

Foto 57 - Rua Barão de Piracicaba, 53.

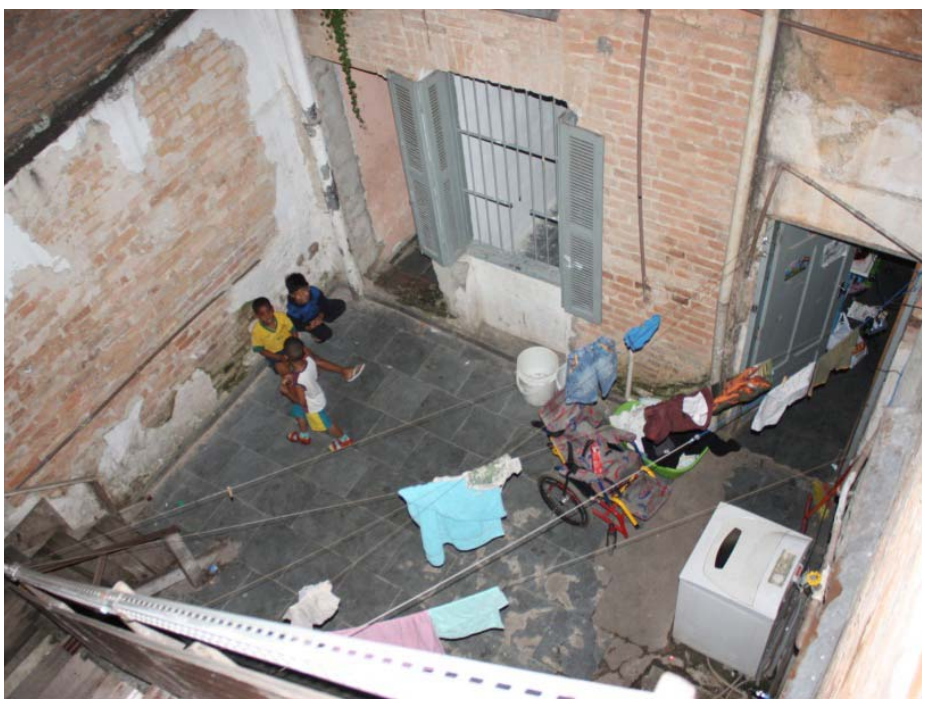

Foto 58 - Rua Barra Funda, 563. 


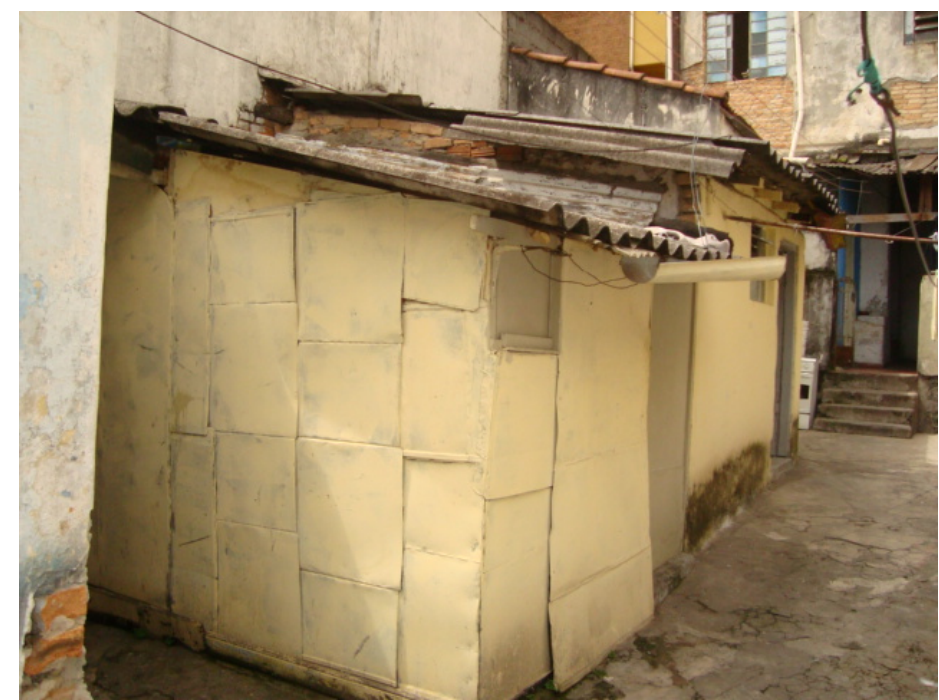

Foto 59 - Rua Bandeirantes, 290.

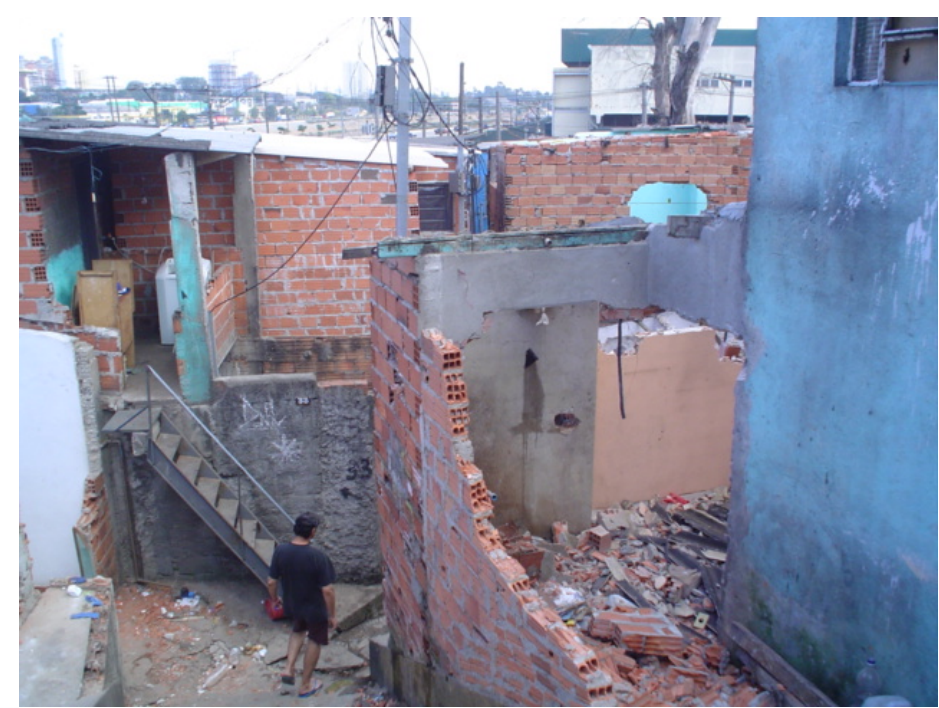

Foto 60 - Rua Caetano Pinto, 215.

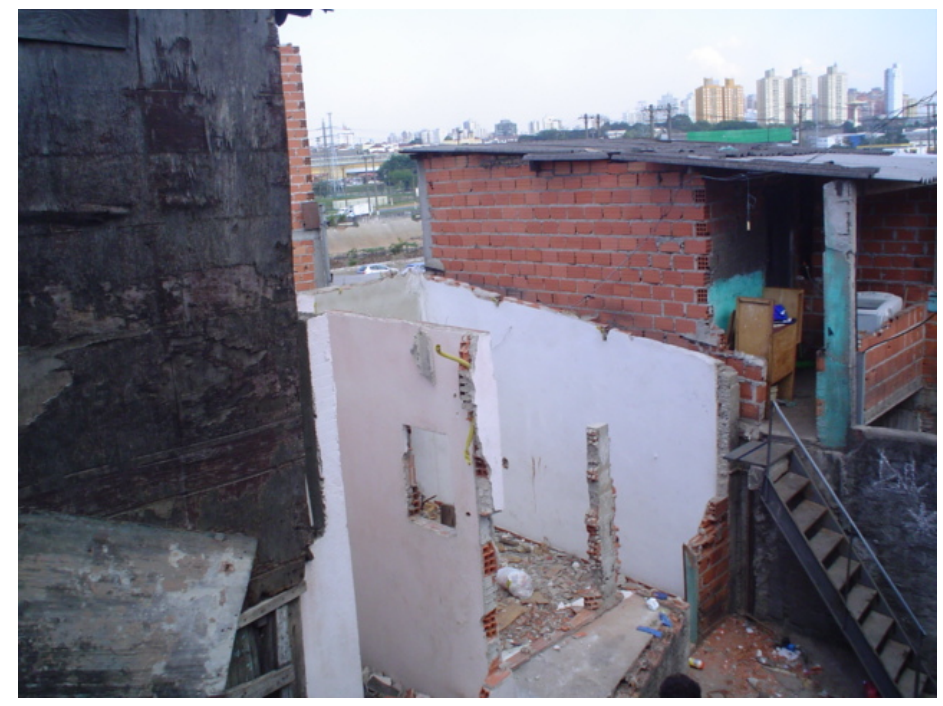

Foto 61 - Rua Caetano Pinto, 215. 


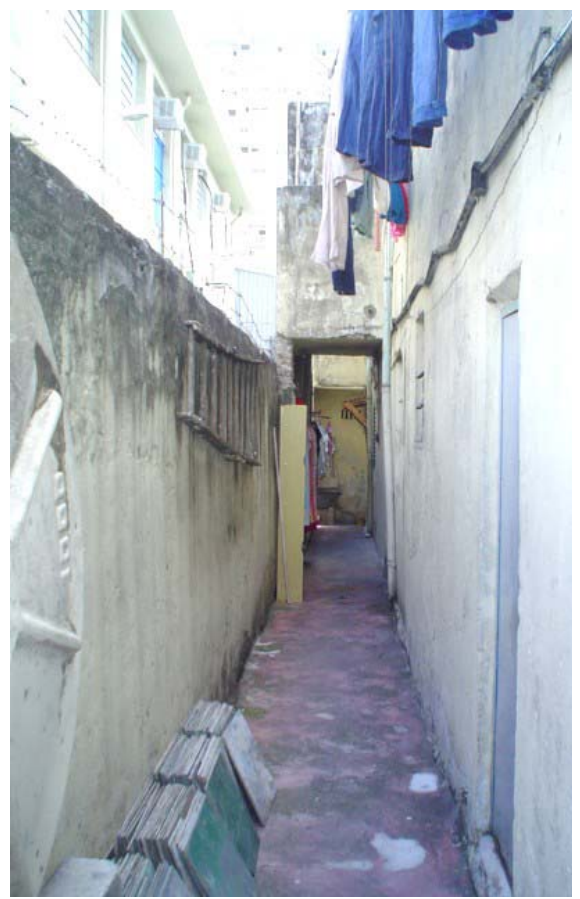

Foto 62 - Rua Barra Funda, 664.

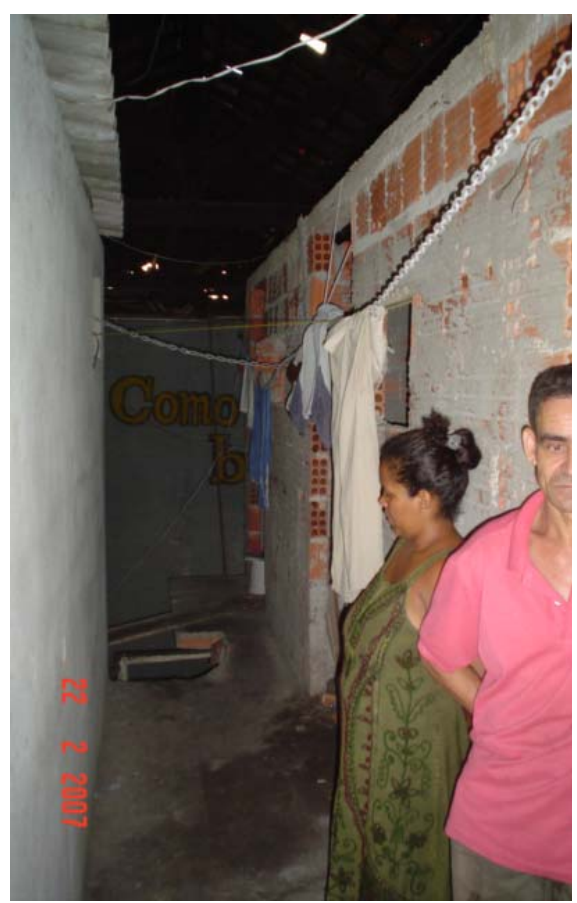

Foto 64 - Rua dos Gusmões, 132.

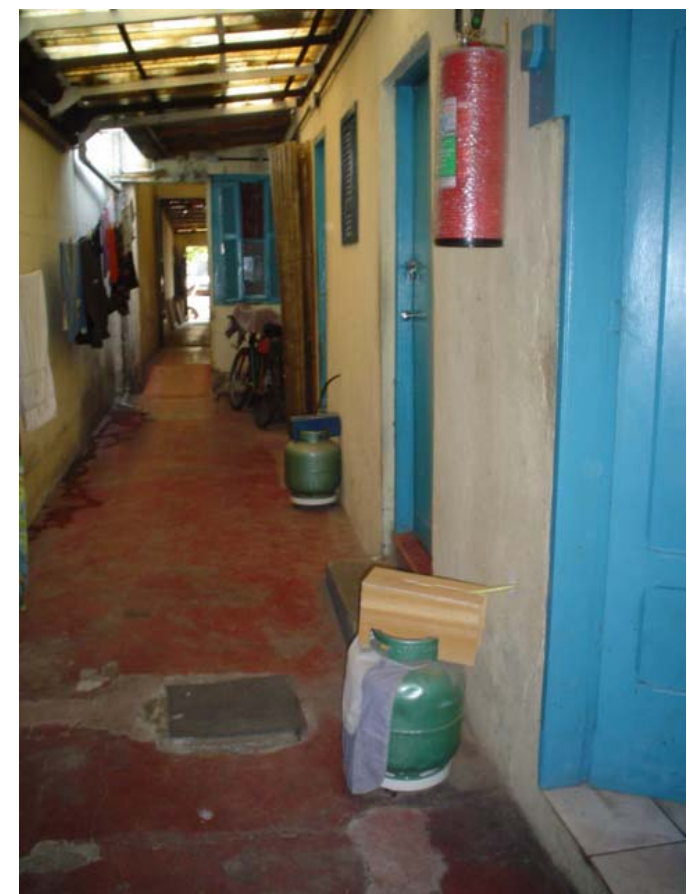

Foto 63 - Rua Gomes Cardim, 97.

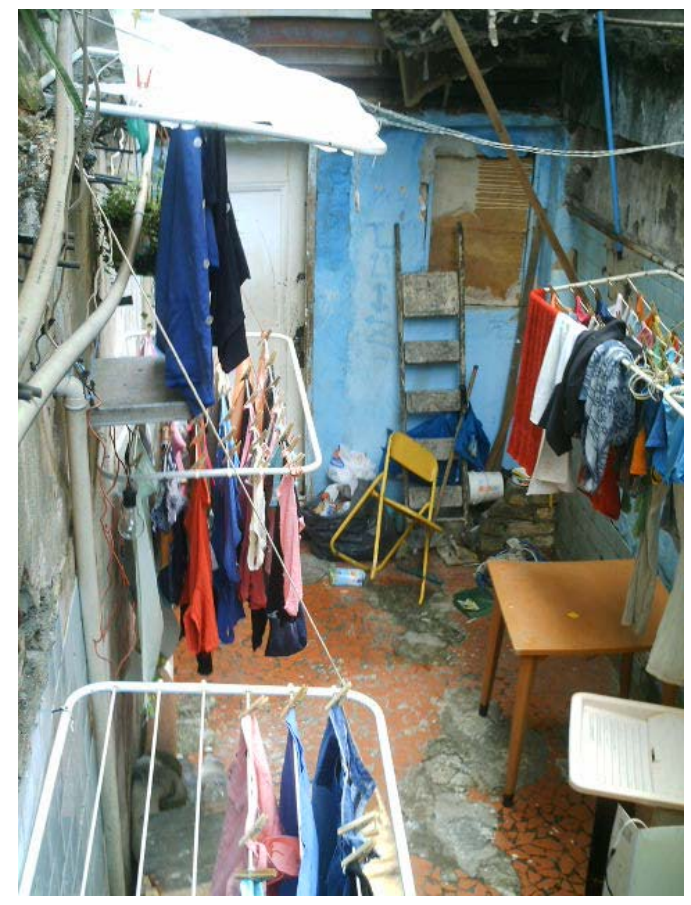

Foto 65 - Rua Helvetia, 508. 
ANEXO F - Fotografias de resultados de obras de imóveis encortiçados.

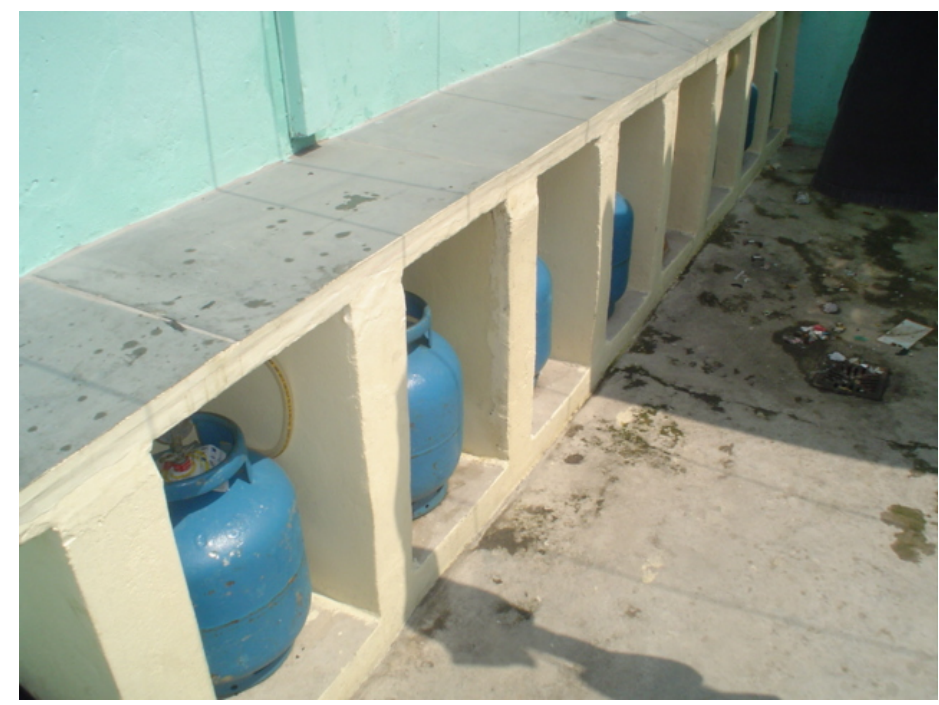

Foto 66 - Rua Abolição, 370.

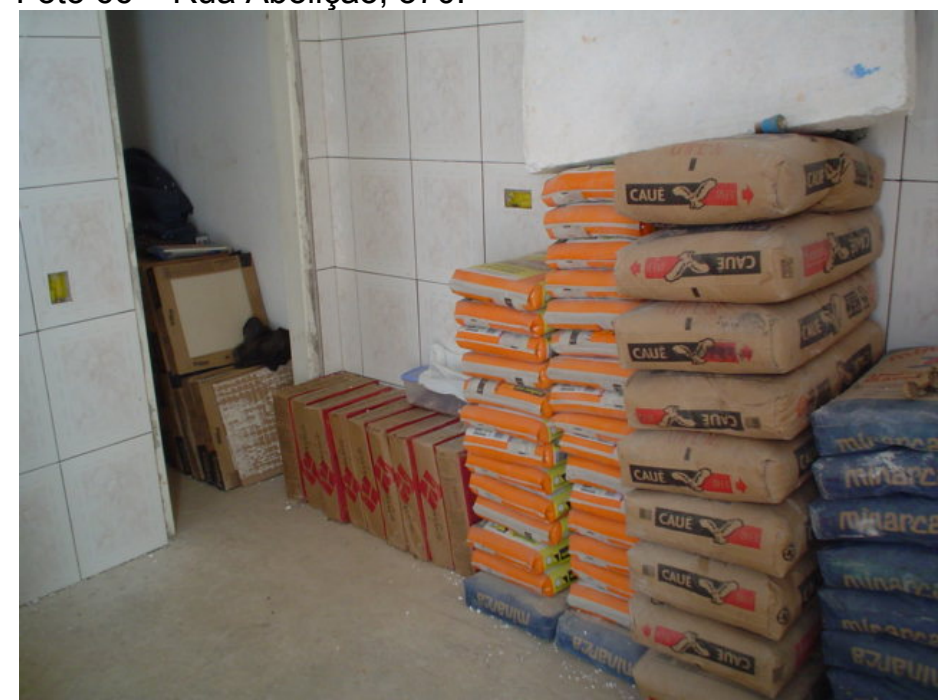

Foto 67 - Rua Came, 123.

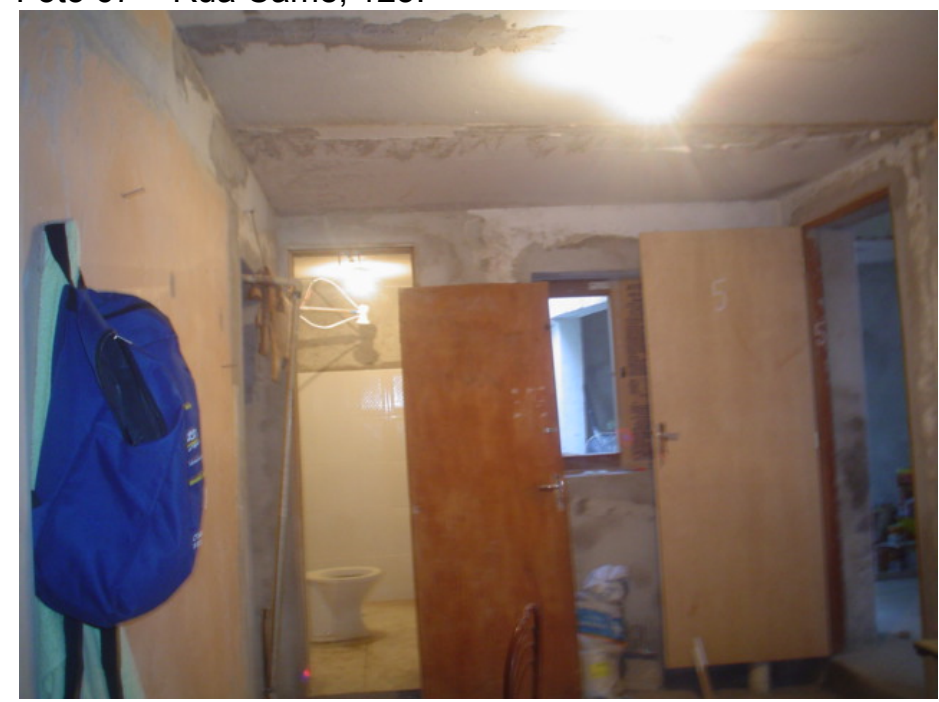

Foto 68 - Rua Angélica, 55. 


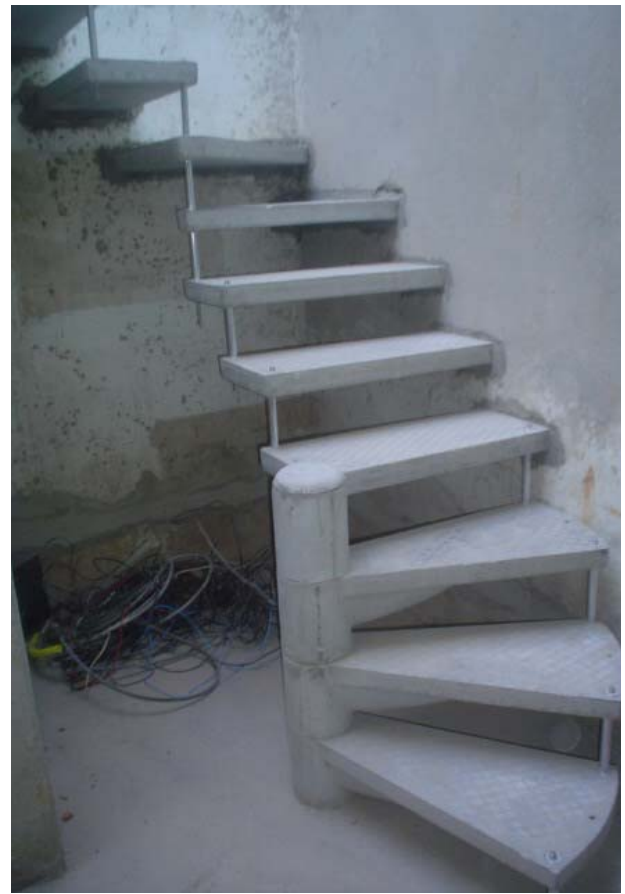

Foto 69 - Rua Angélica, 55.

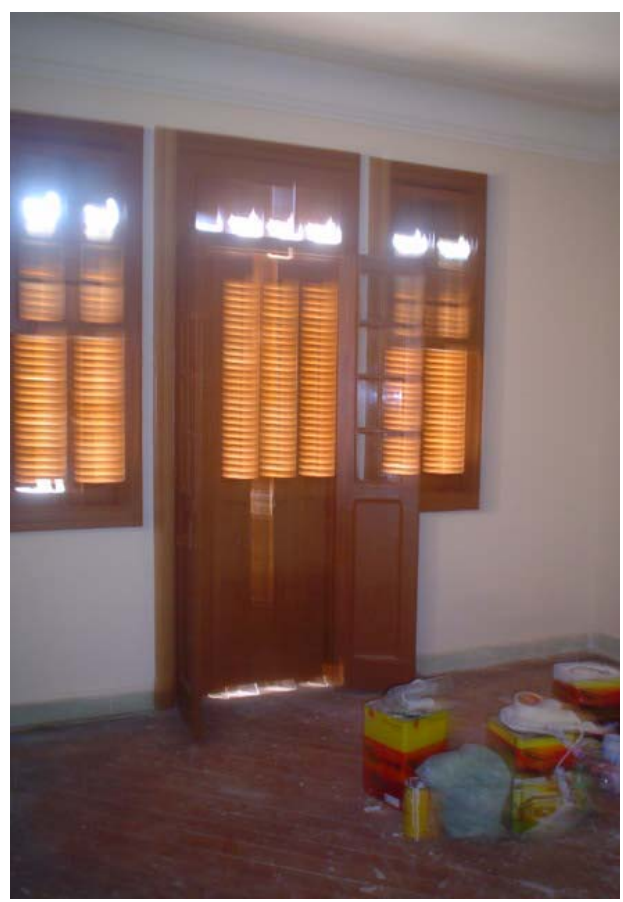

Foto 71 - Rua Angélica, 55.

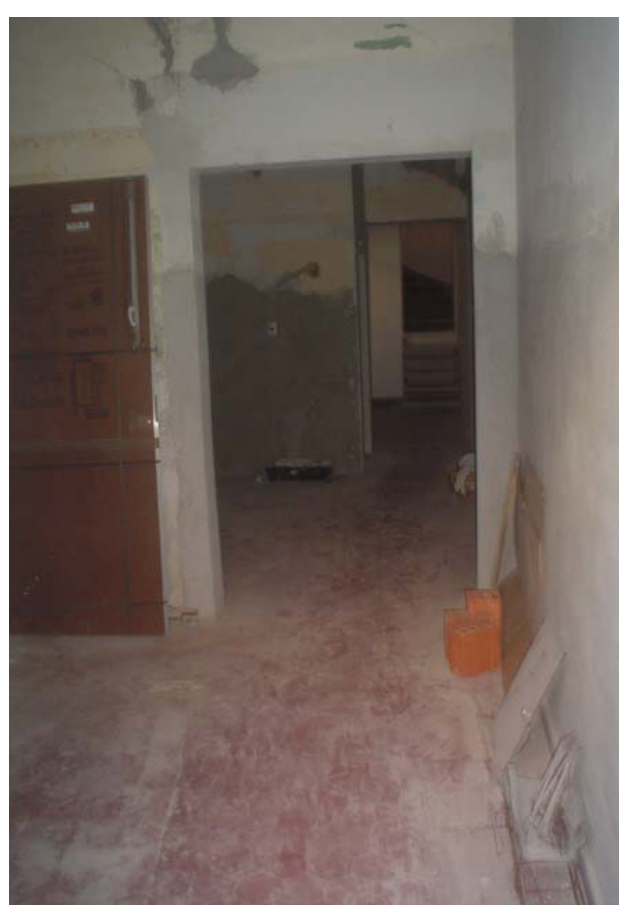

Foto 70 - Rua Angélica, 55.

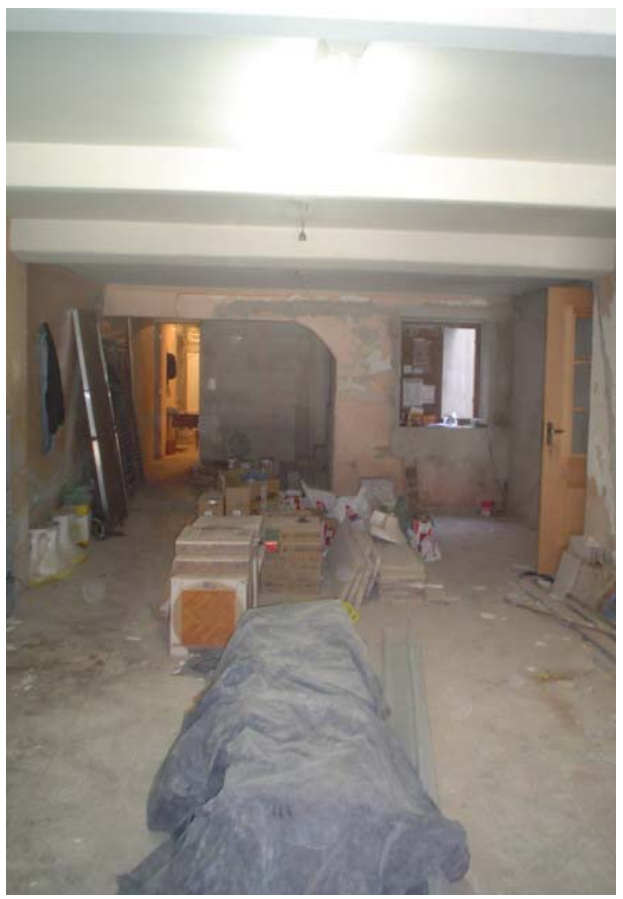

Foto 72 - Rua Angélica, 55. 


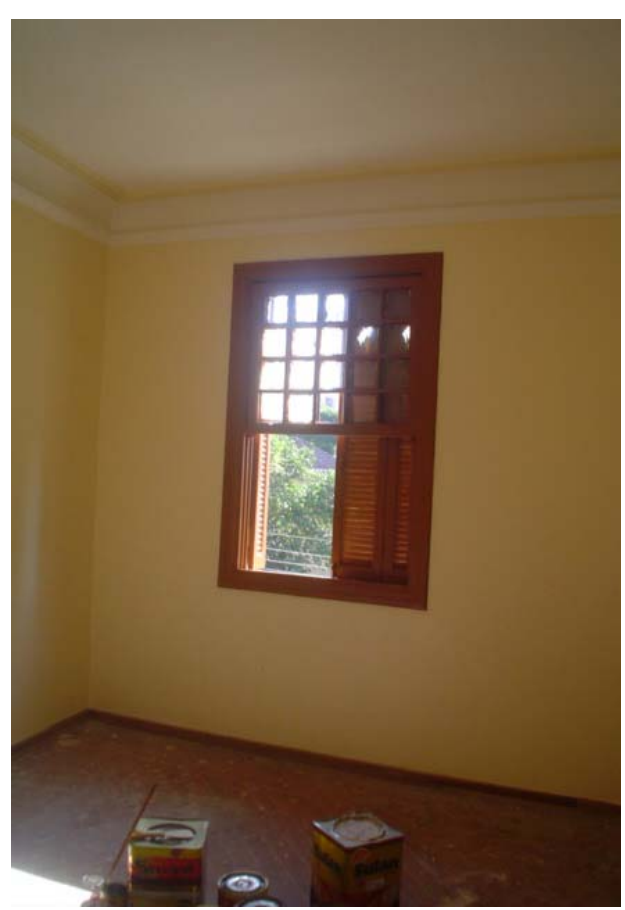

Foto 73 - Rua Angélica, 55.

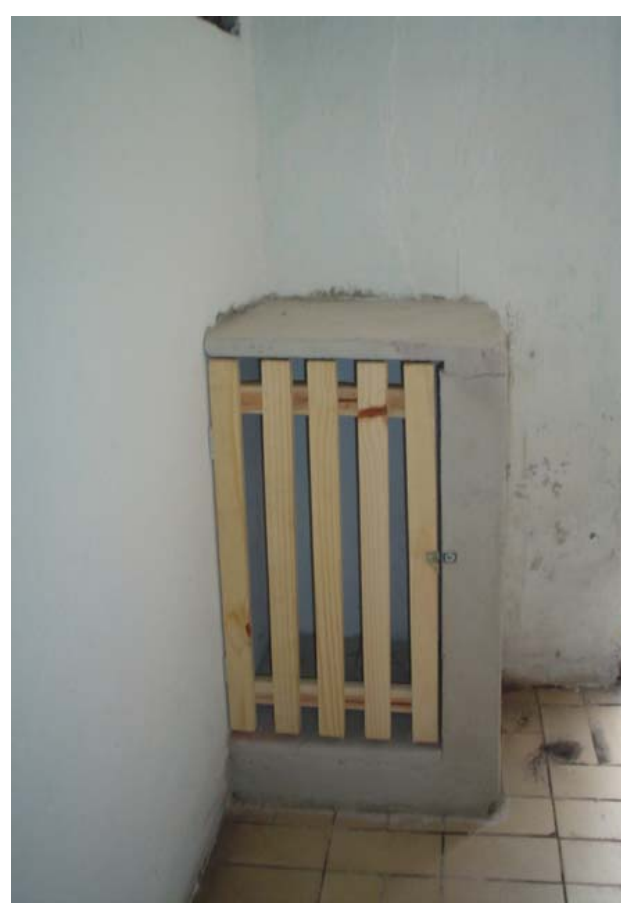

Foto 75 - Rua Abolição, 104.

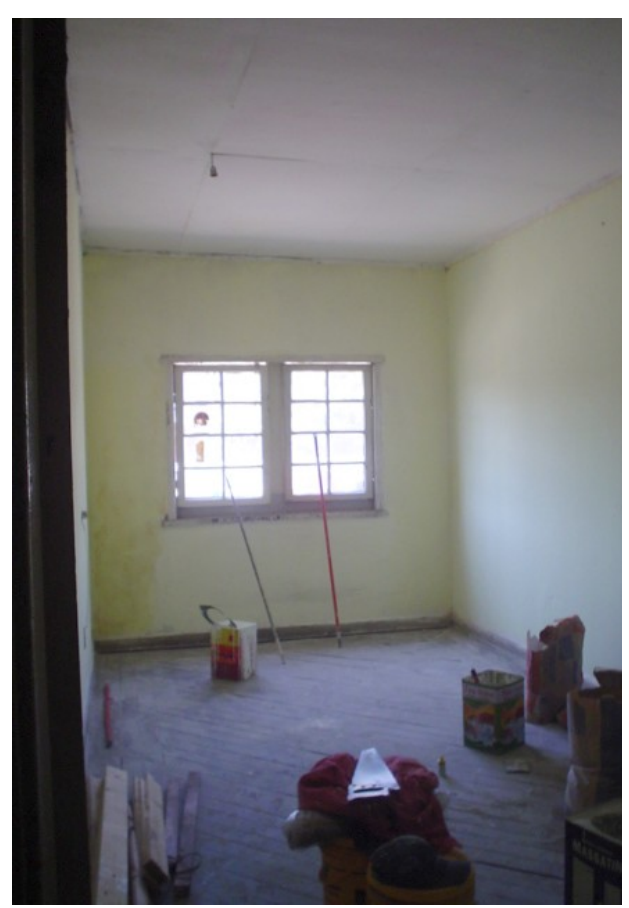

Foto 74 - Avenida Alcântara Machado, 1000.

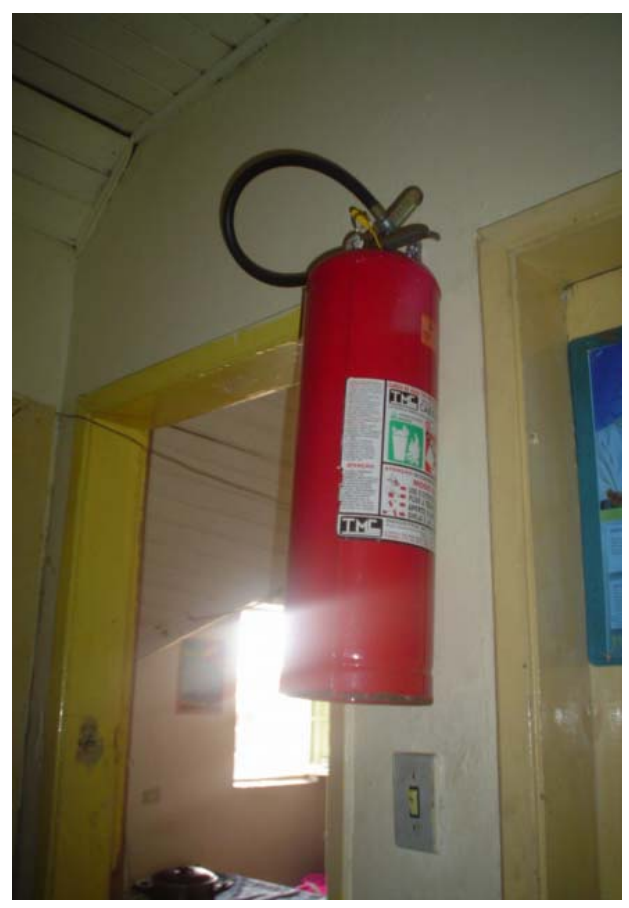

Foto 76 - Rua Abolição, 370. 


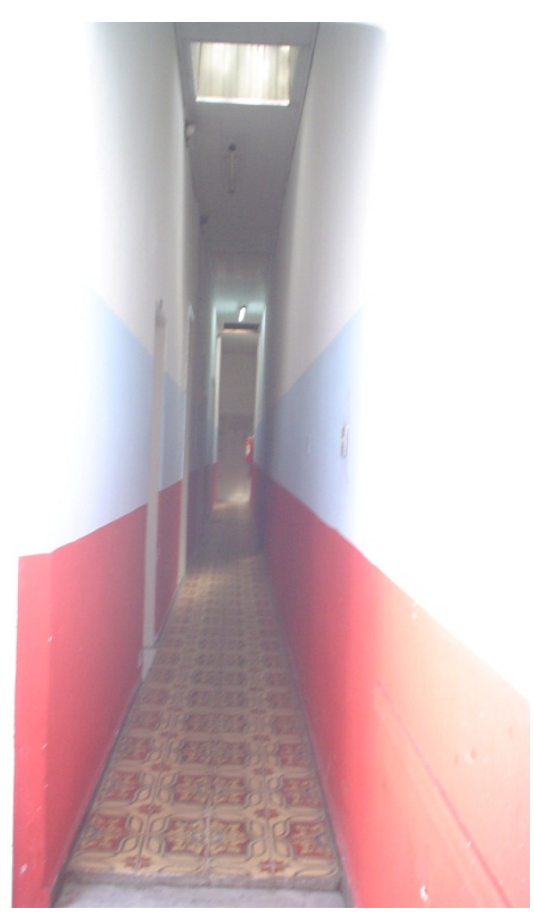

Foto 77 - Rua Barão de Piracicaba,

53.

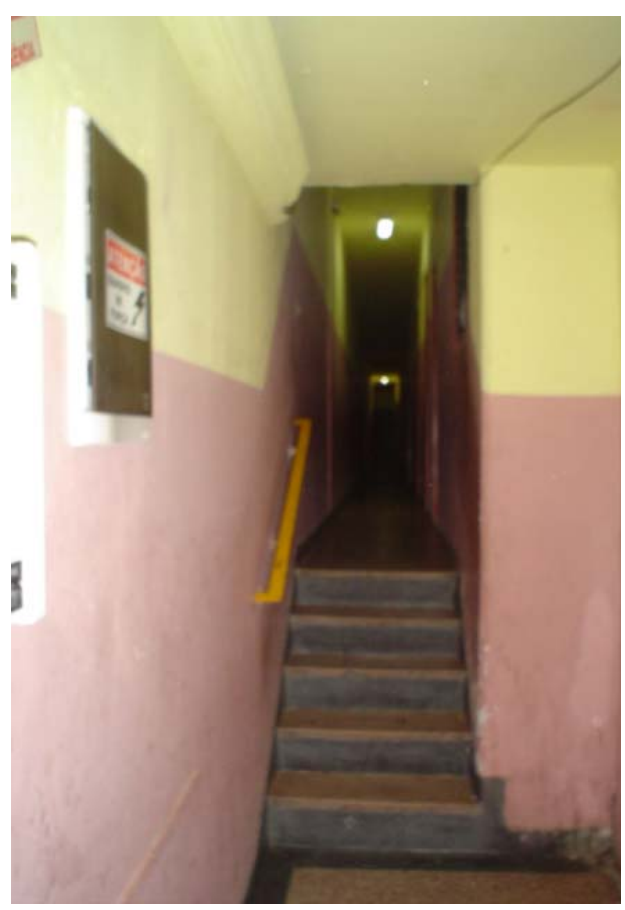

Foto 79 - Rua Barão de Piracicaba,

53.

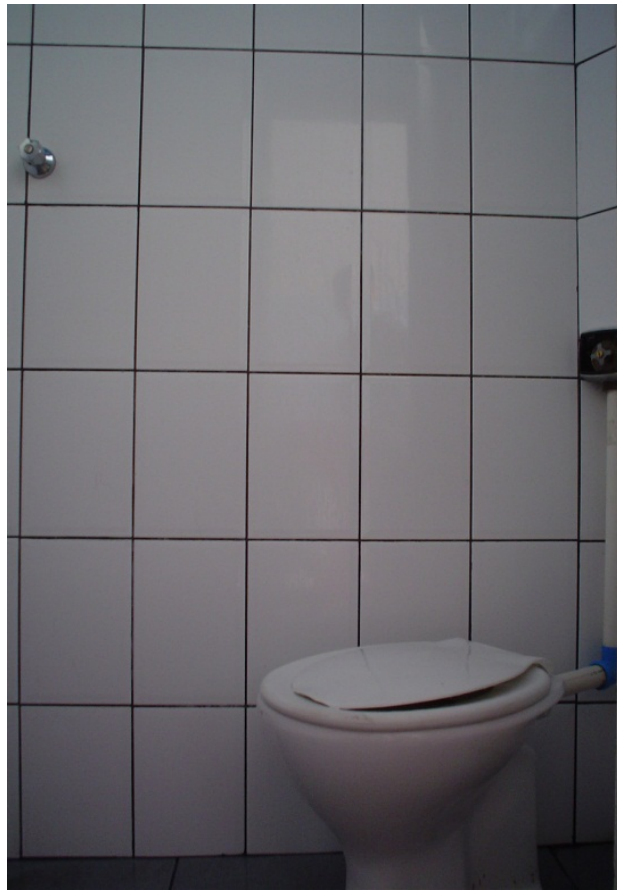

Foto 78 - Rua Barão de Piracicaba, 53.

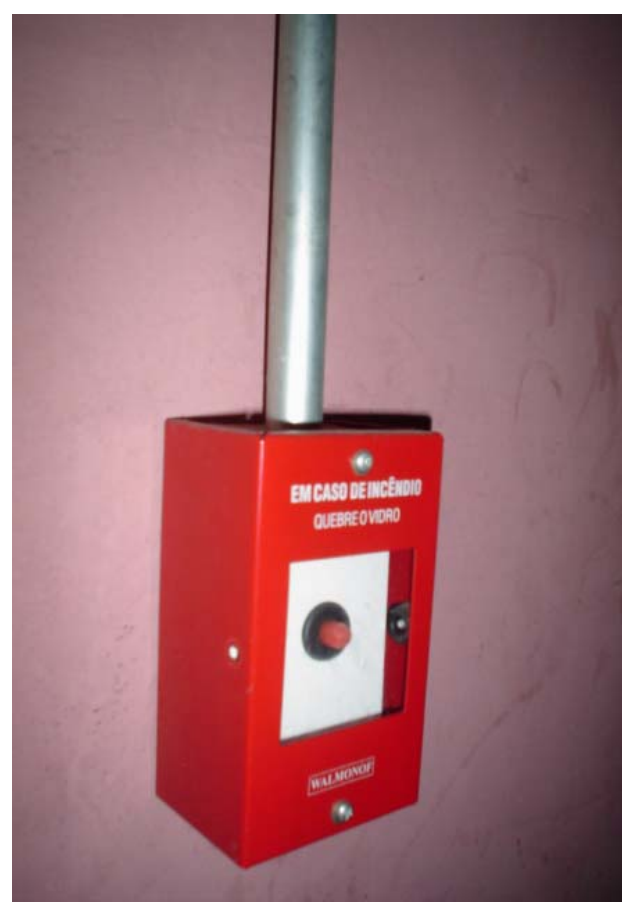

Foto 80 - Rua Barão de Piracicaba, 53. 


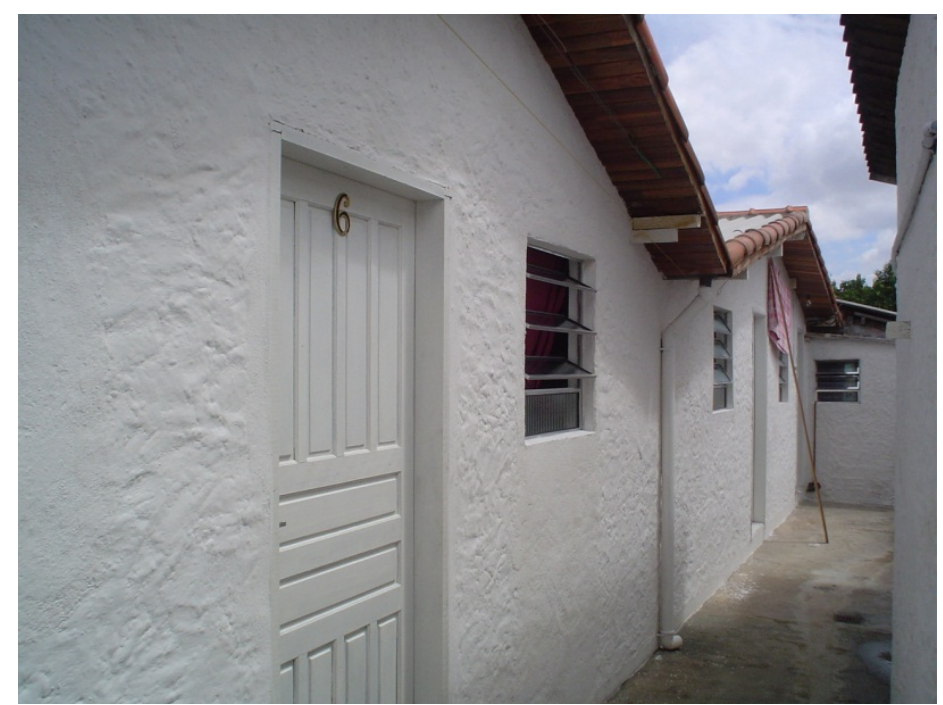

Foto 81 - Rua Curupacê, 264.

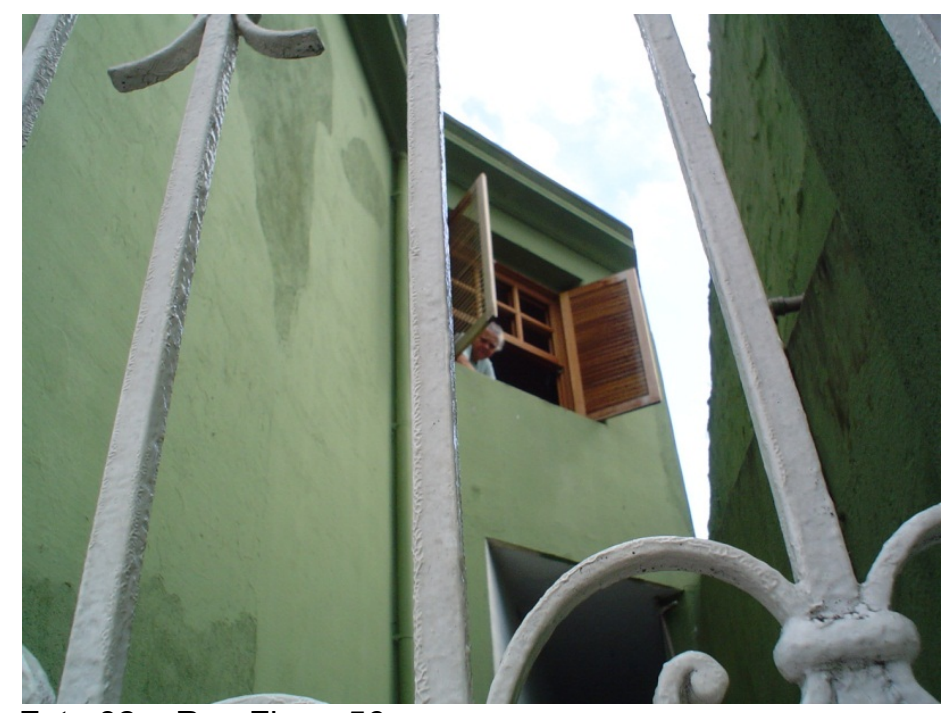

Foto 82 - Rua Flora, 56

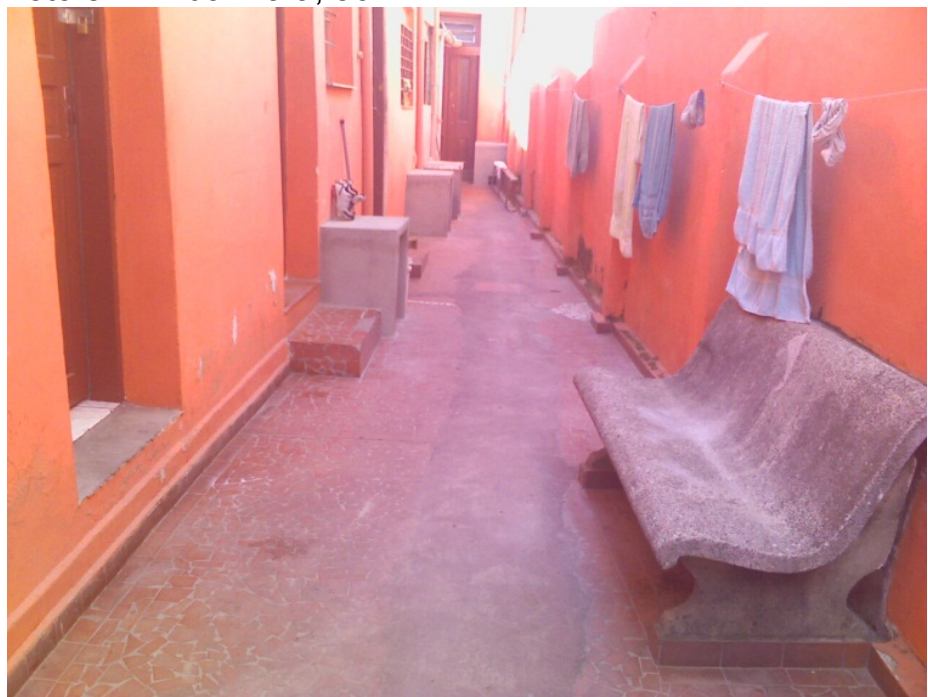

Foto 83 - Rua Belisário de Souza, 44. 


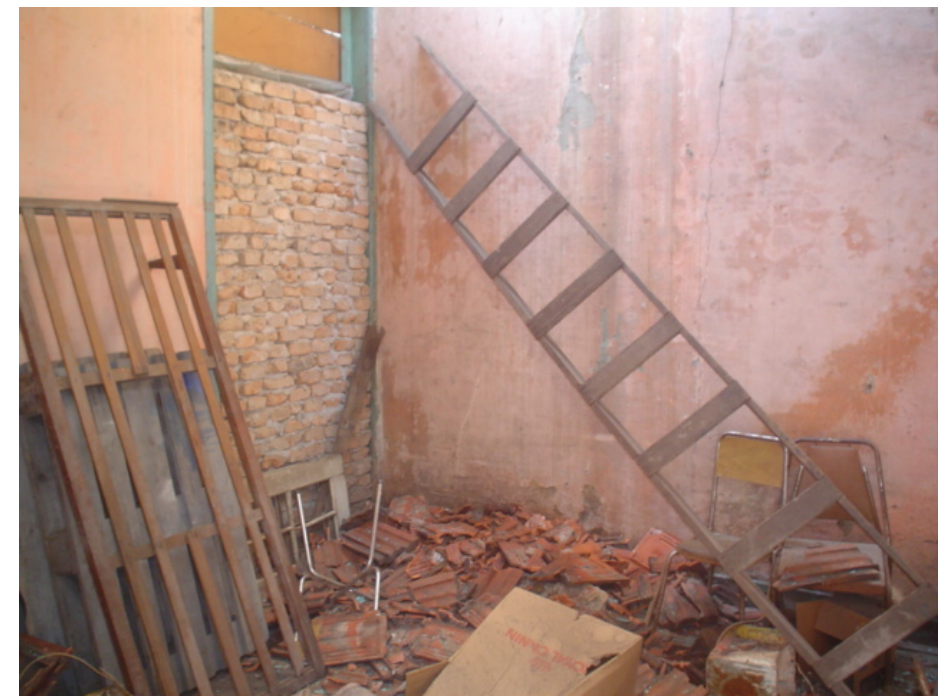

Foto 84 - Rua Dr. Clementino, 585.

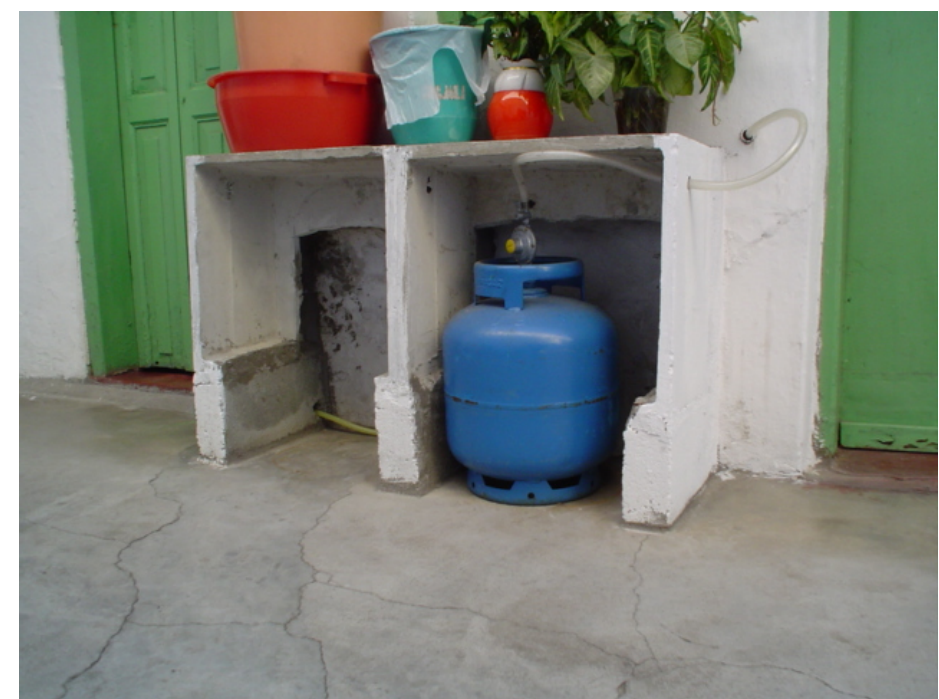

Foto 85 - Rua do Hipódromo, 166.

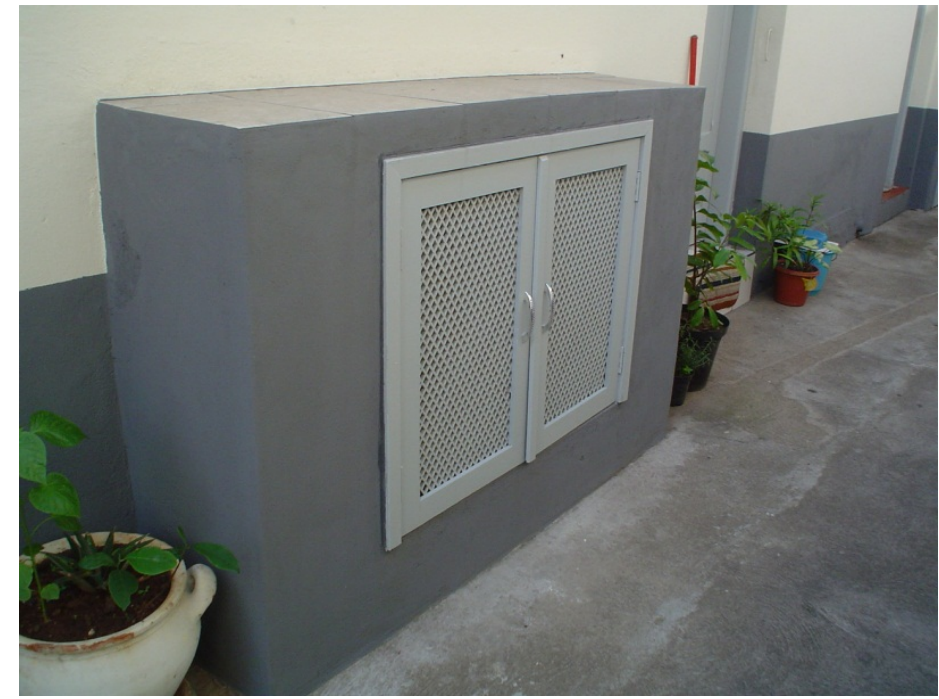

Foto 86 - Rua Serra do Jairé, 275. 


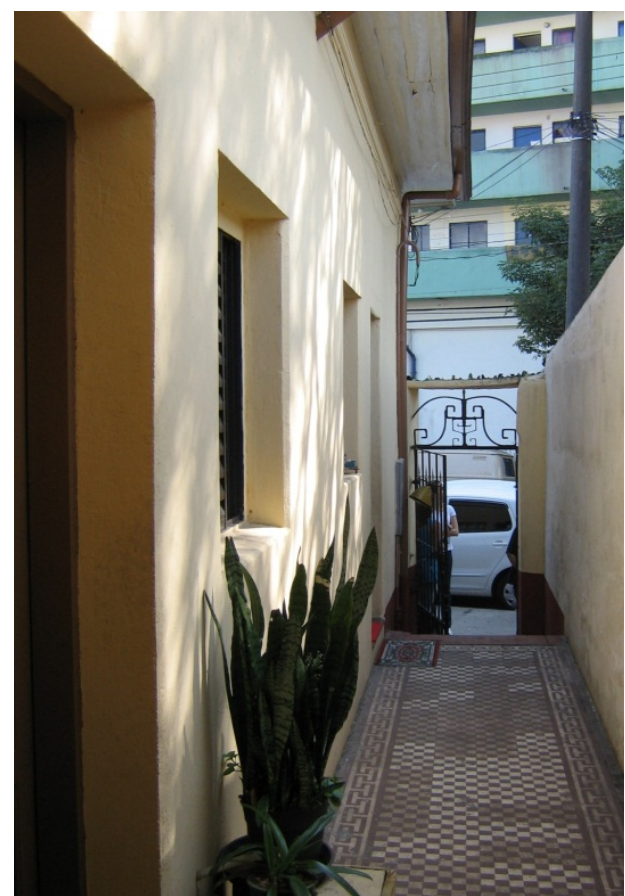

Foto 87 - Rua Araguaia, 168.

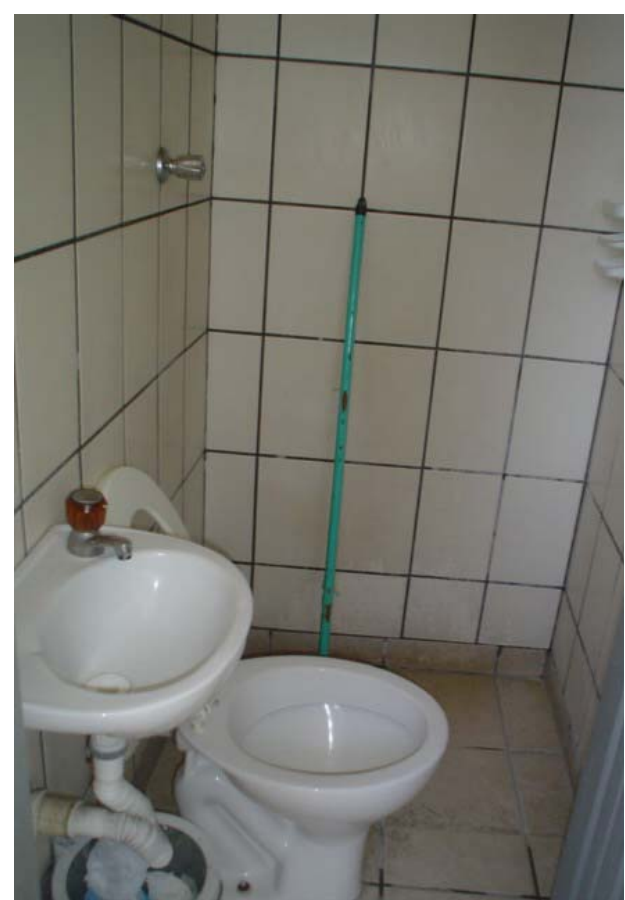

Foto 89 - Rua Conselheiro Ramalho, 478.

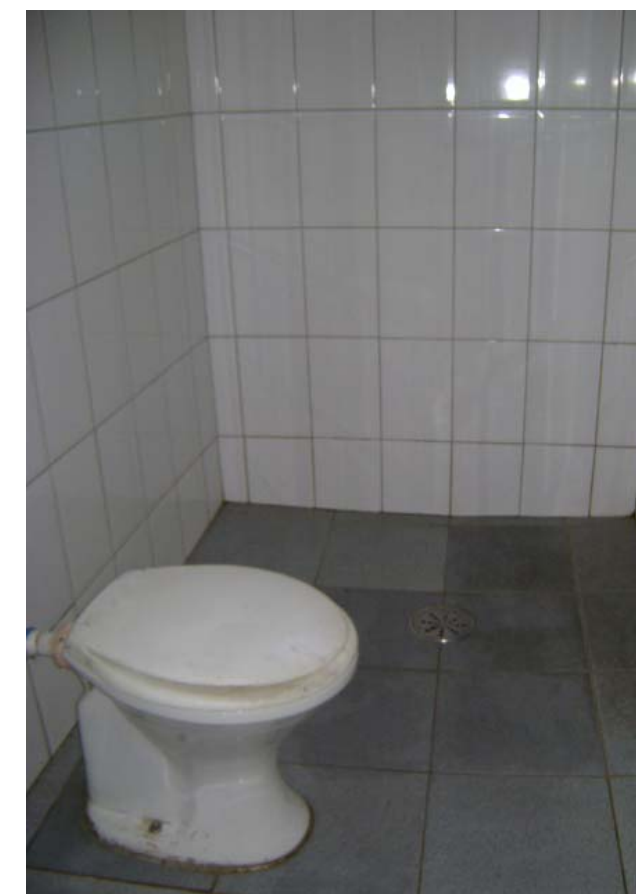

Foto 88 - Rua Barão de Piracicaba, 53.

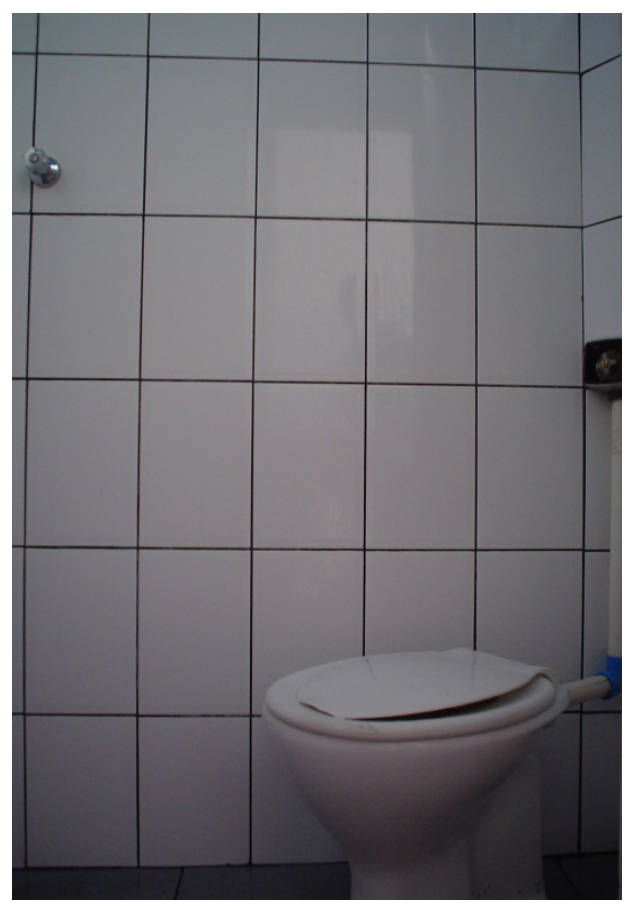

Foto 90 - Rua Barão de Piracicaba, 53. 


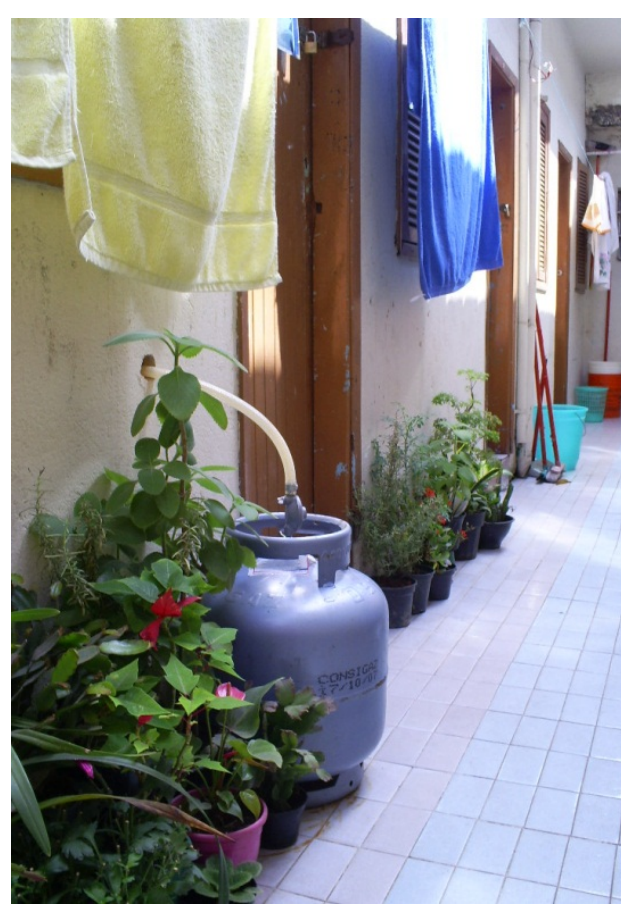

Foto 91 - Rua Dino Bueno, 470.

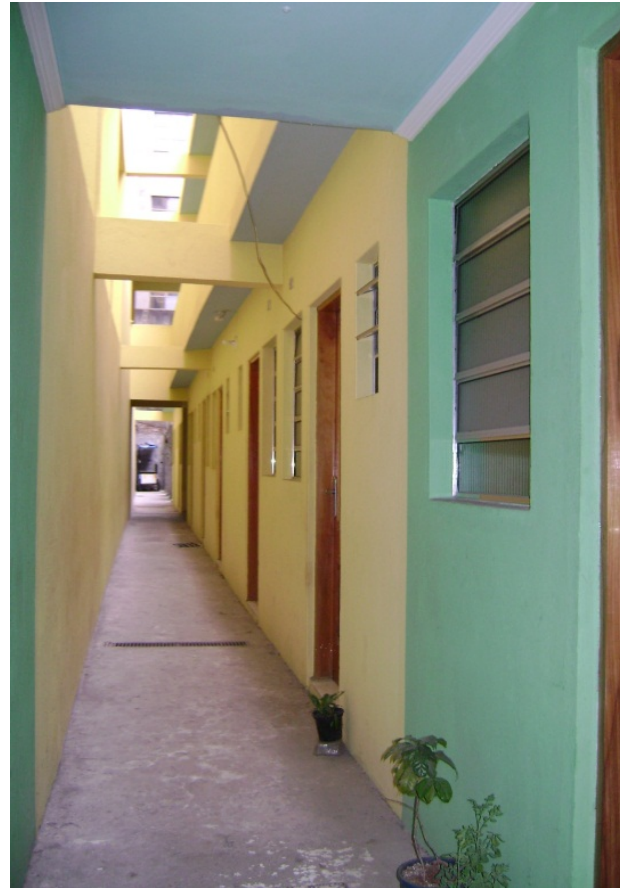

Foto 92 - Rua do Gasômetro, 769.

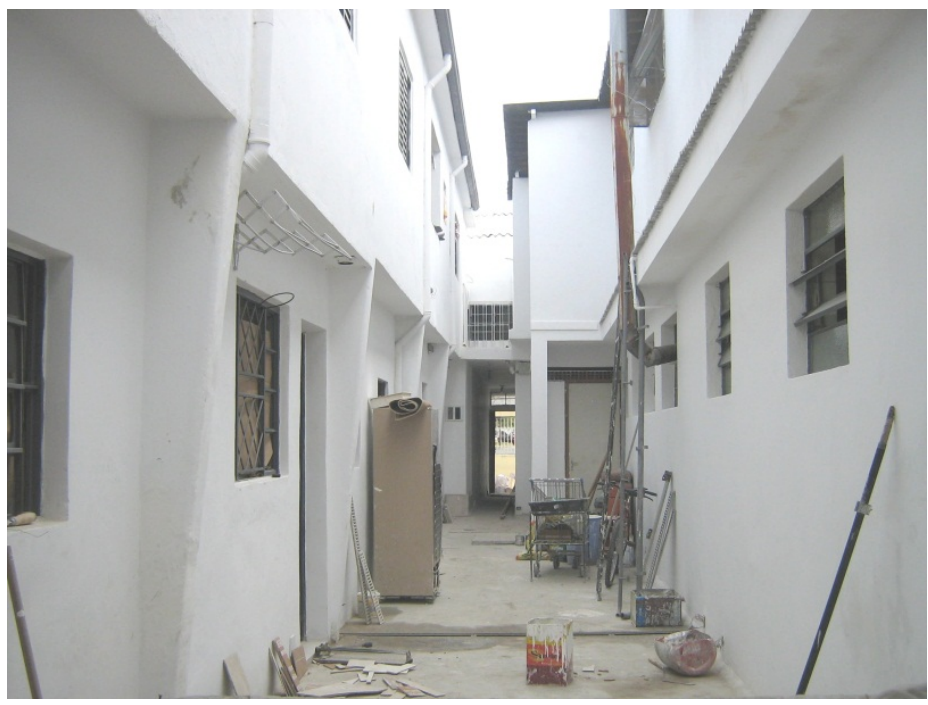

Foto 93 - Rua Visconde de Parnaíba, 1544. 


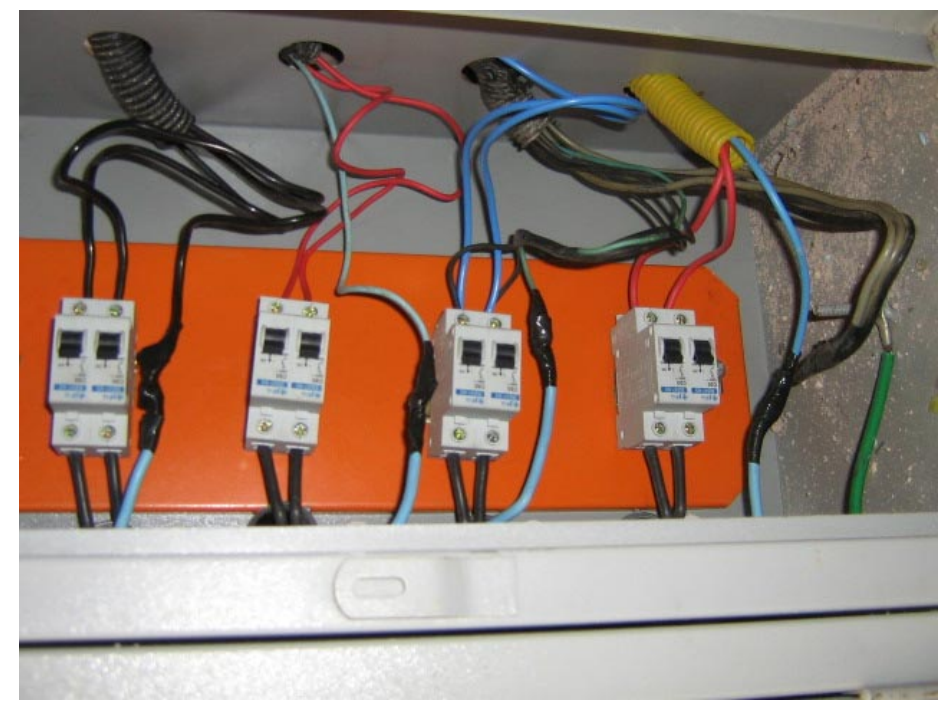

Foto 94 - Rua Belo Horizonte, 43.

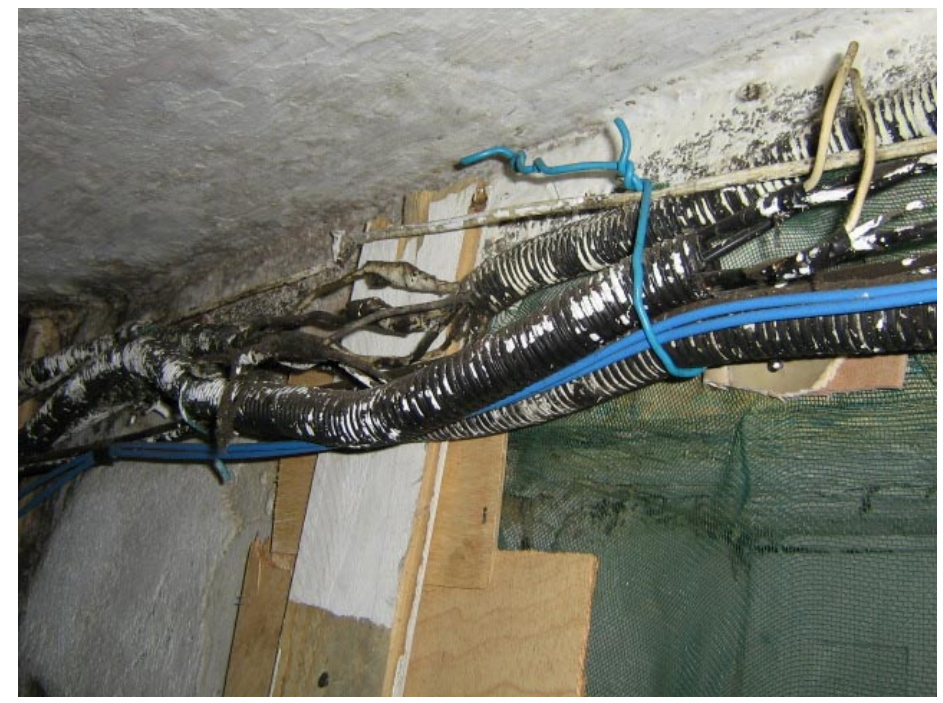

Foto 95 - Rua Belo Horizonte, 43.

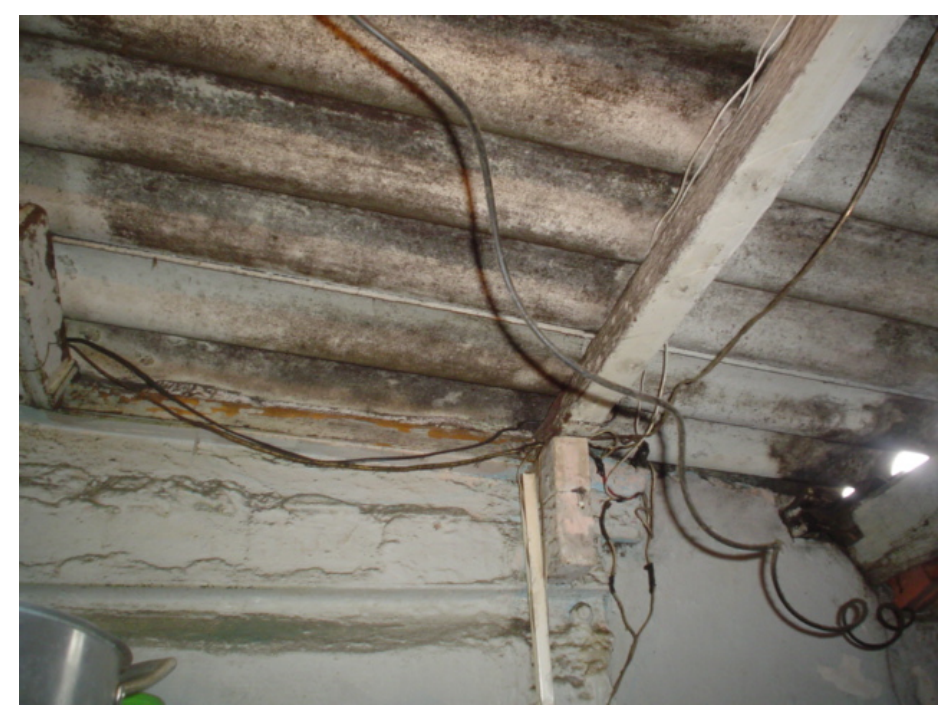

Foto 96 - Rua Eloi Cerqueira, 237. 
ANEXO G - Fotografias realizadas em "Vistorias Prévias" de imóveis encortiçados - Variedades.
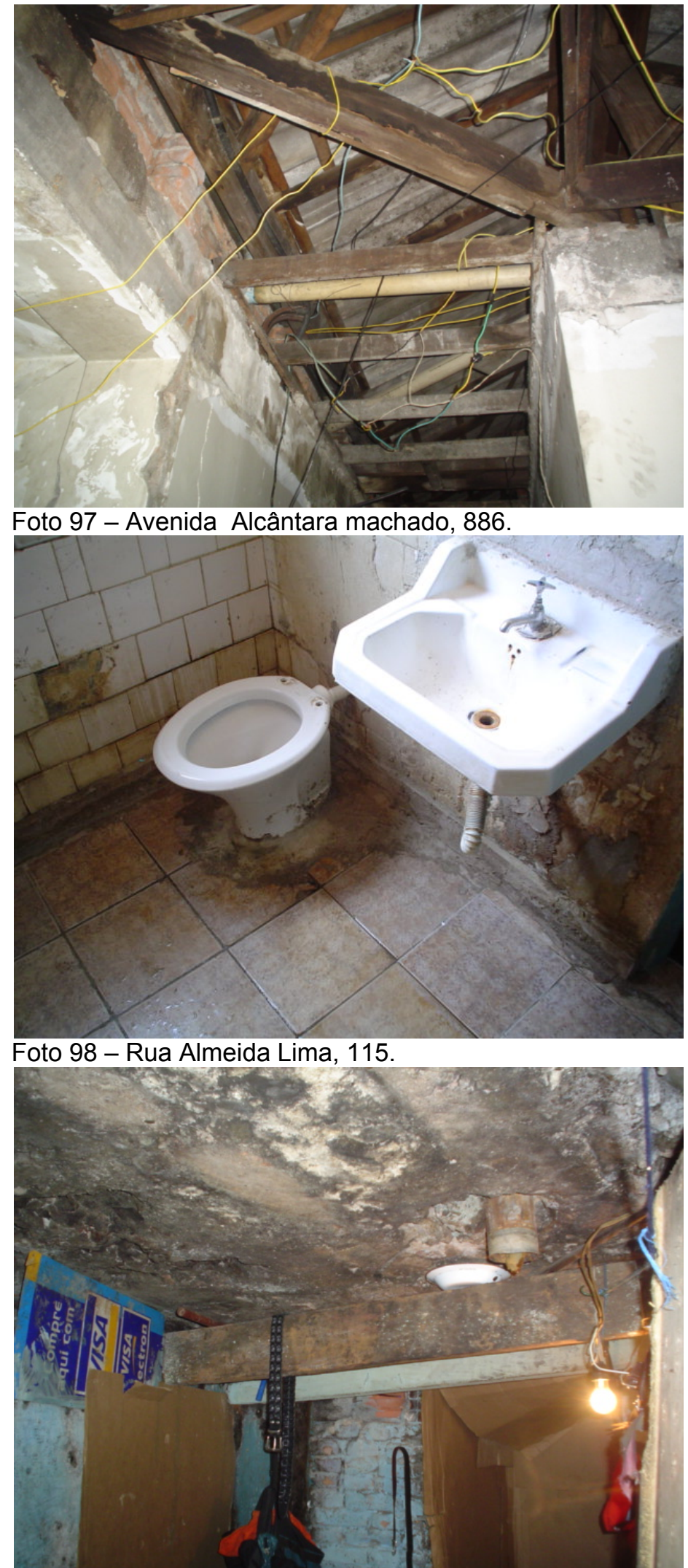

Foto 99 - Avenida do Estado, 2347. 


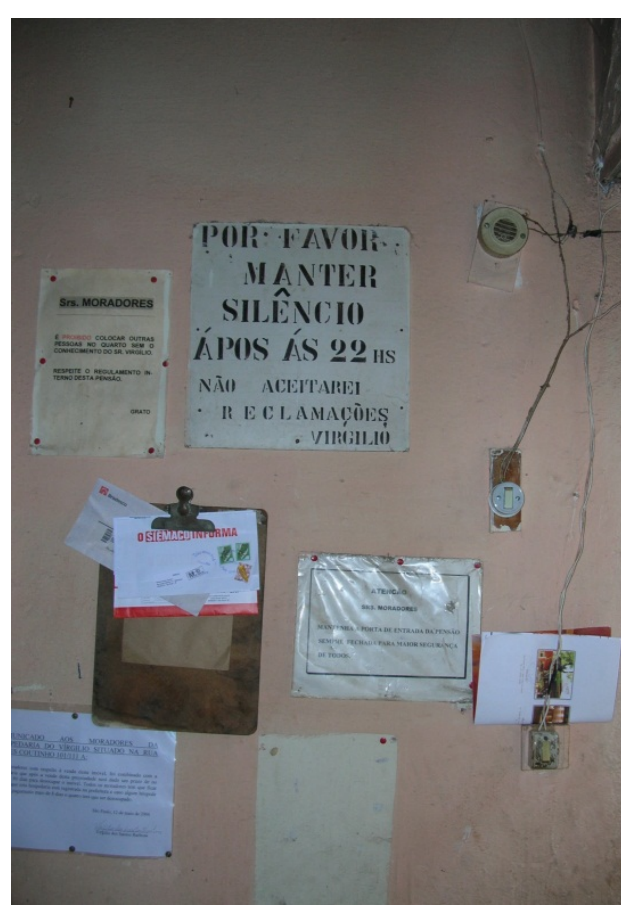

Foto 100 - Rua Lopes Coutinho, 111.

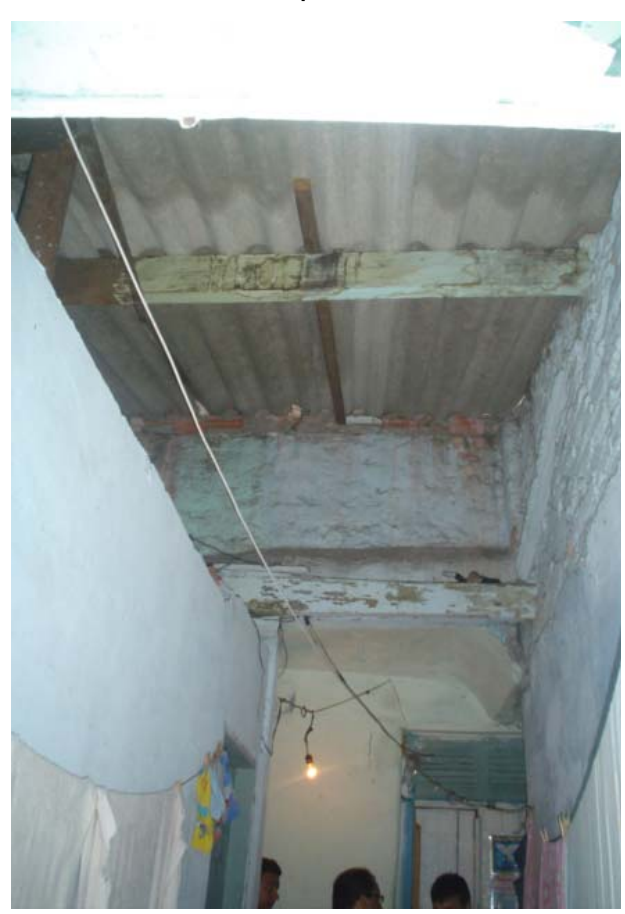

Foto 102 - Rua Asdrúbal do Nascimento, 160.

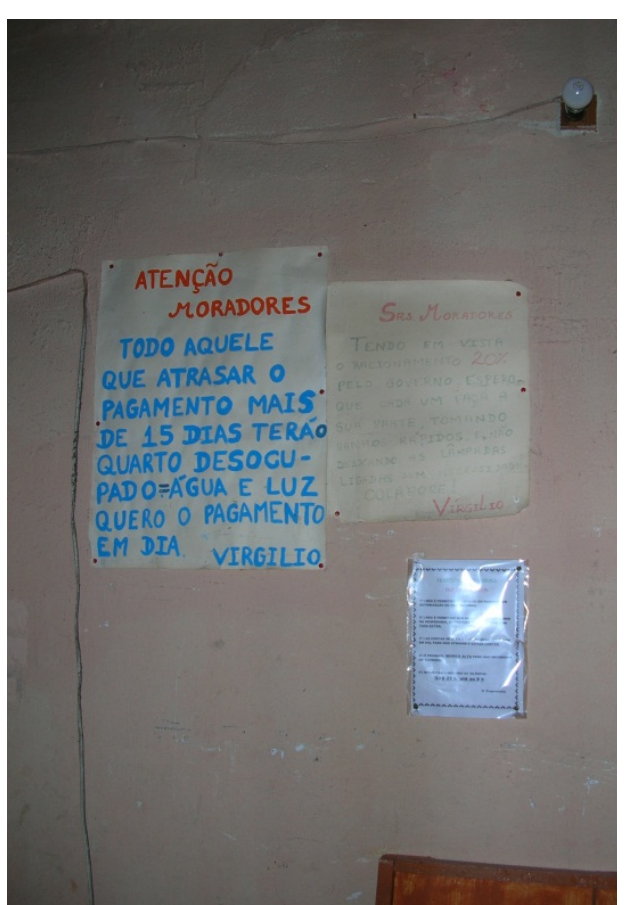

Foto 101 - Rua Lopes Coutinho, 111.

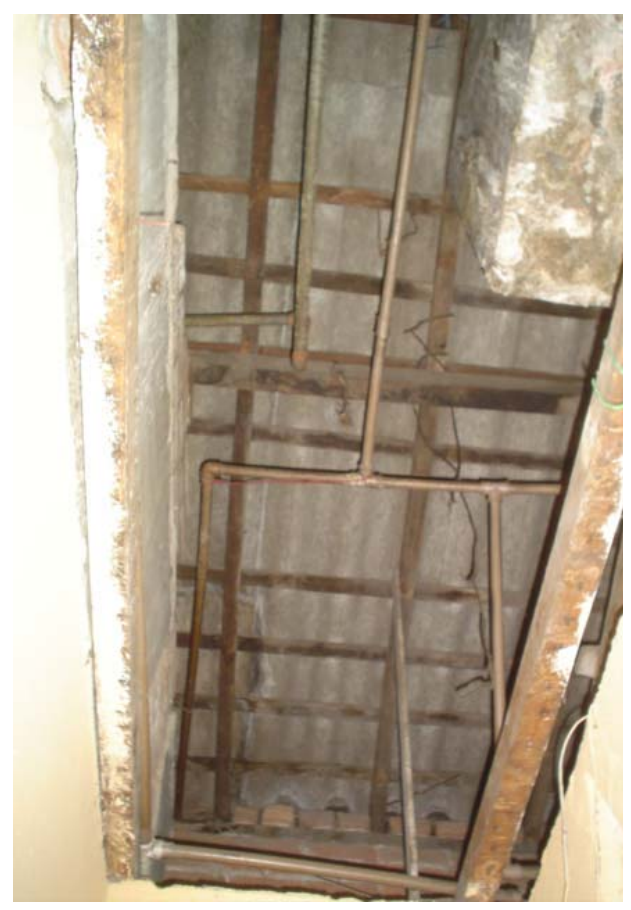

Foto 103 - Rua Apa, 31. 


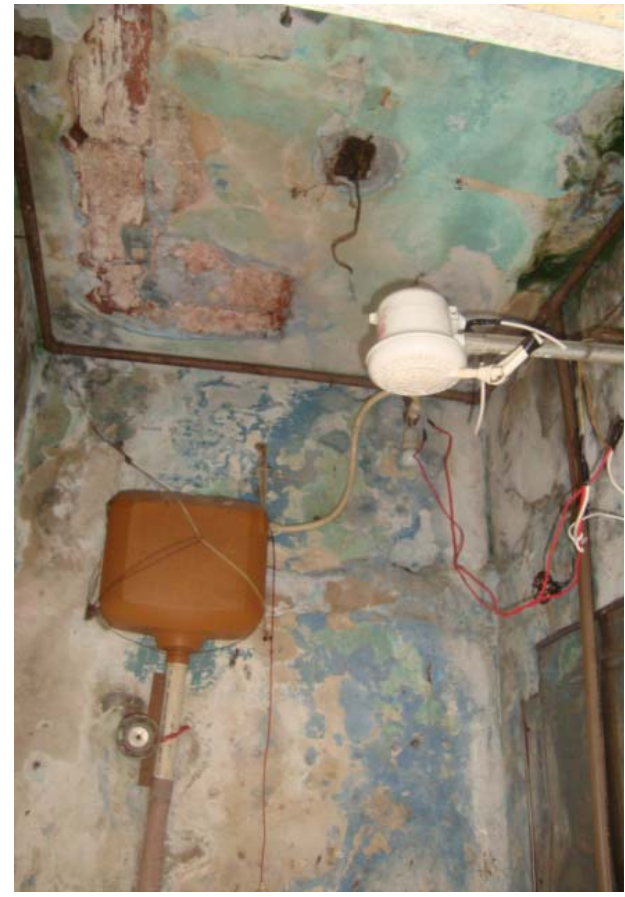

Foto 104 - Rua Bandeirantes, 290.

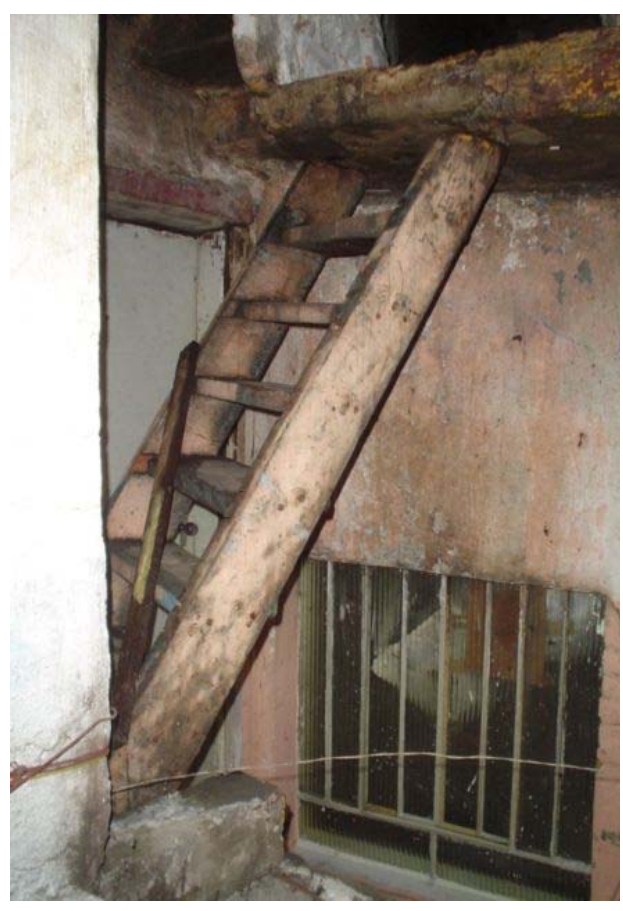

Foto 106 - Rua Intendência, 65.

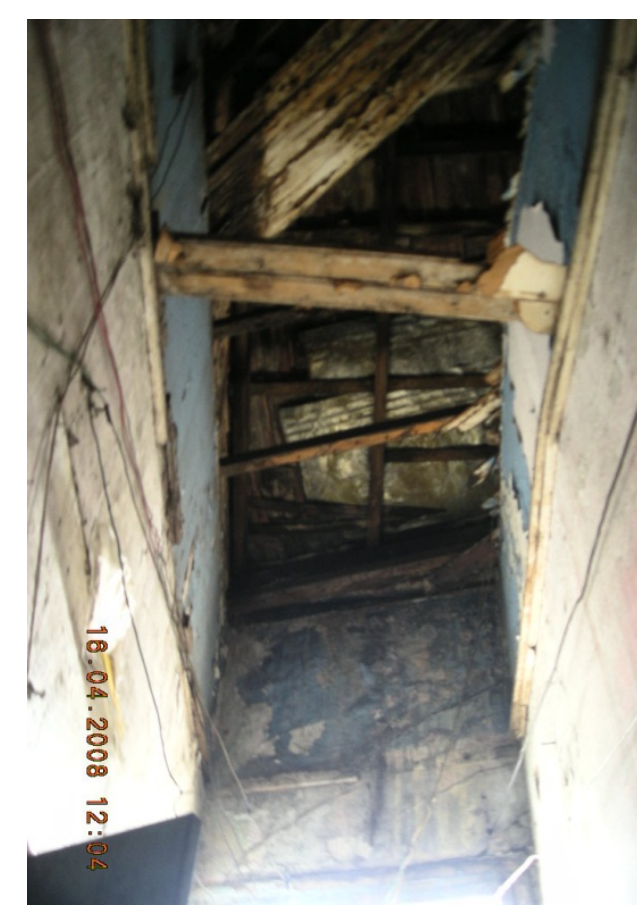

Foto 105 - Rua 21 de Abril, 169.

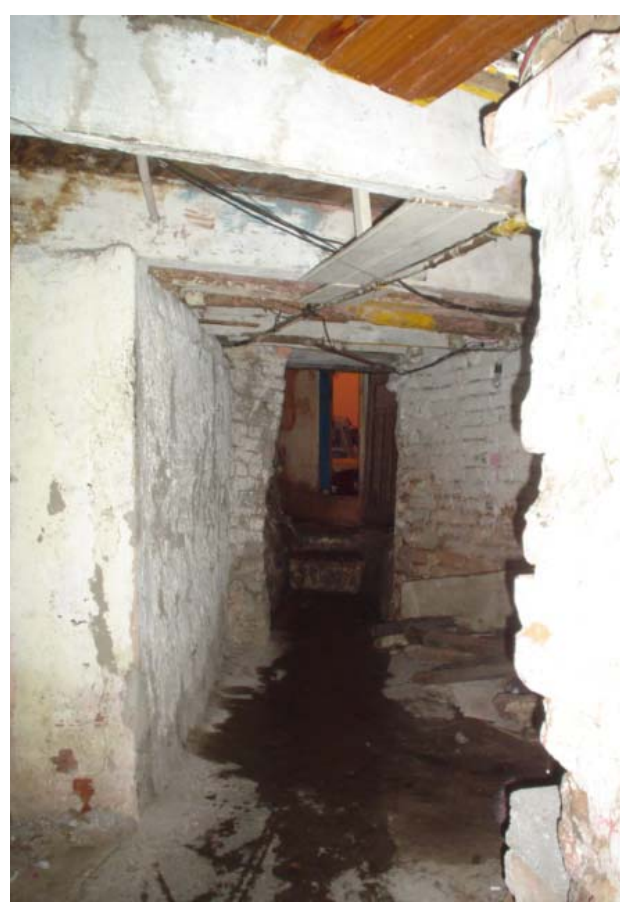

Foto 107 - Rua Intendência, 65. 


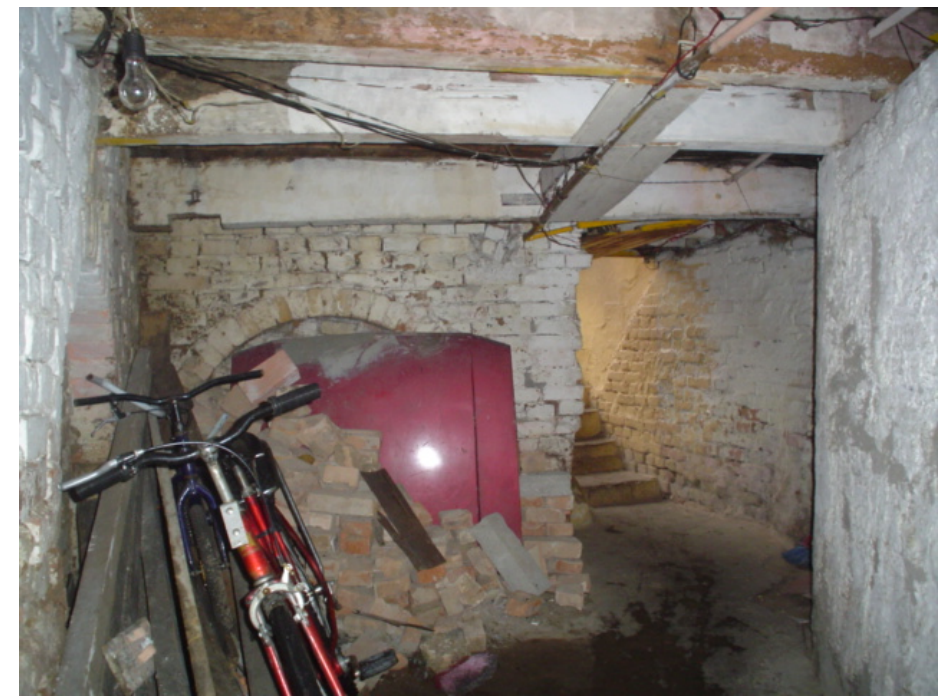

Foto 108 - Rua Intendência, 65.

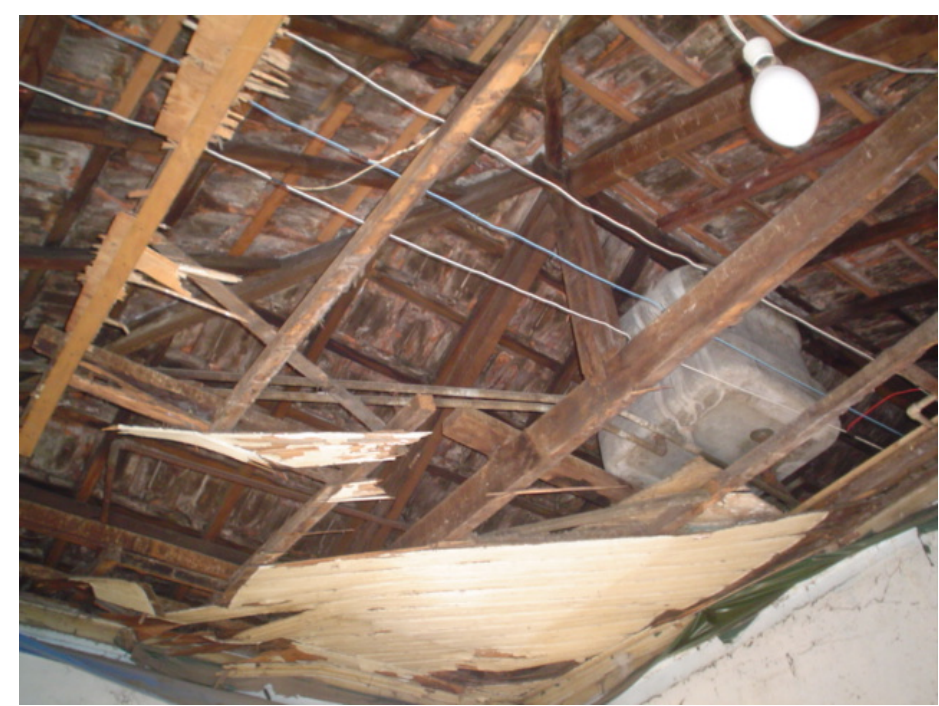

Foto 109 - Rua Henrique Dias, 196.

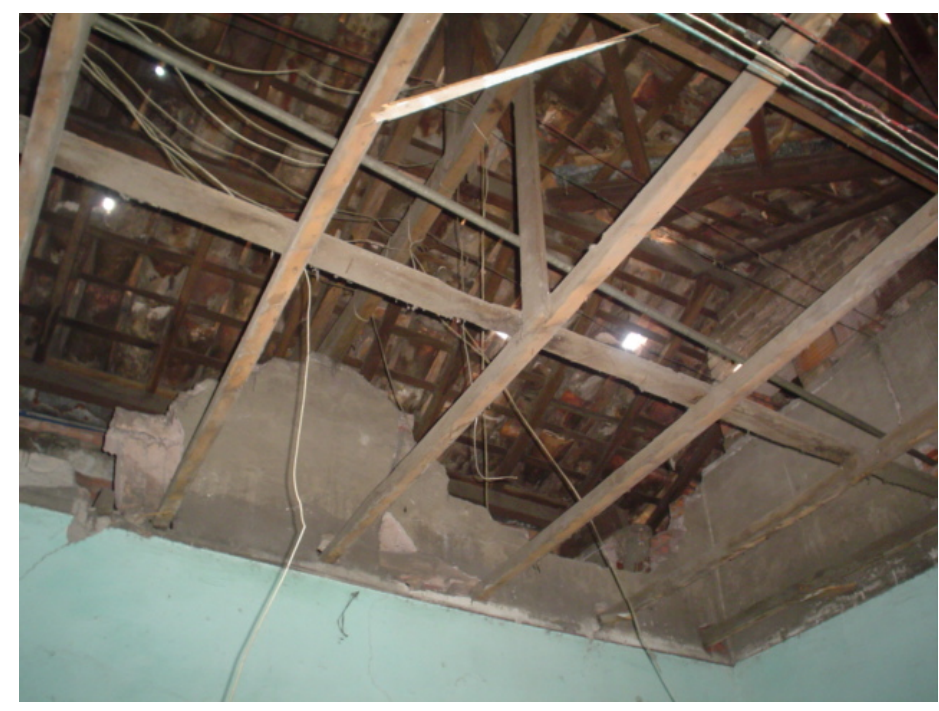

Foto 110 - Rua João Alves Lima, 50. 


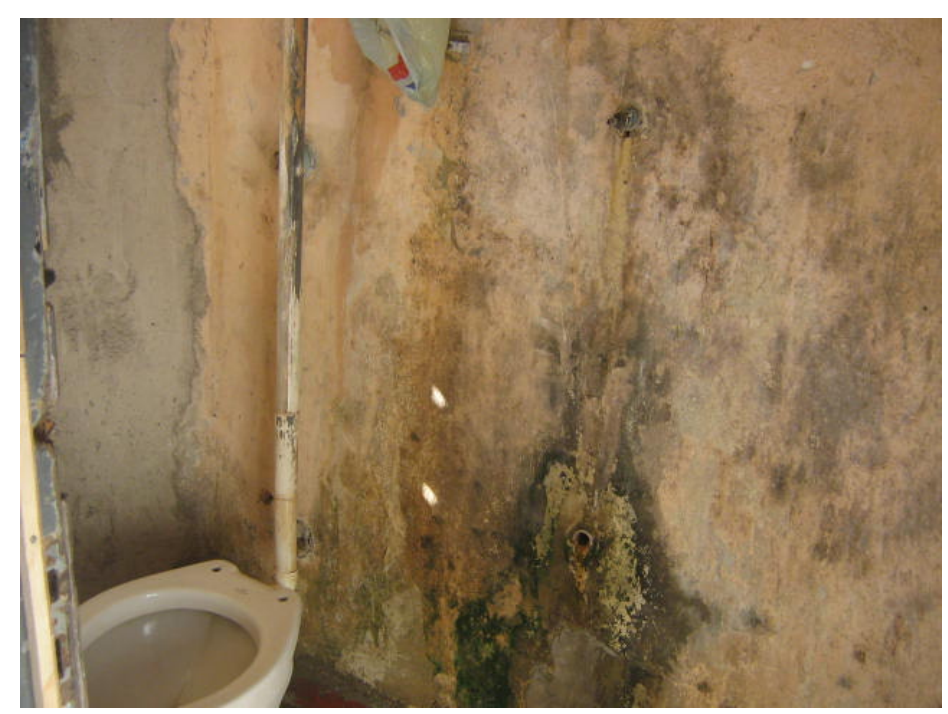

Foto 111 - Rua Brigadeiro Machado, 83.

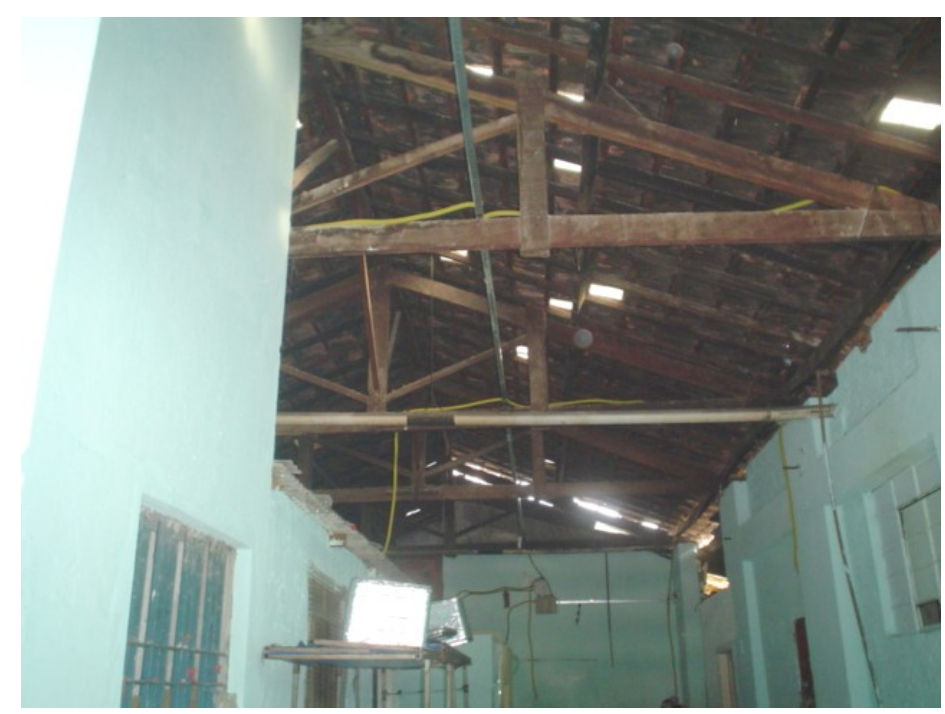

Foto 112 - Rua Brigadeiro Machado, 255.

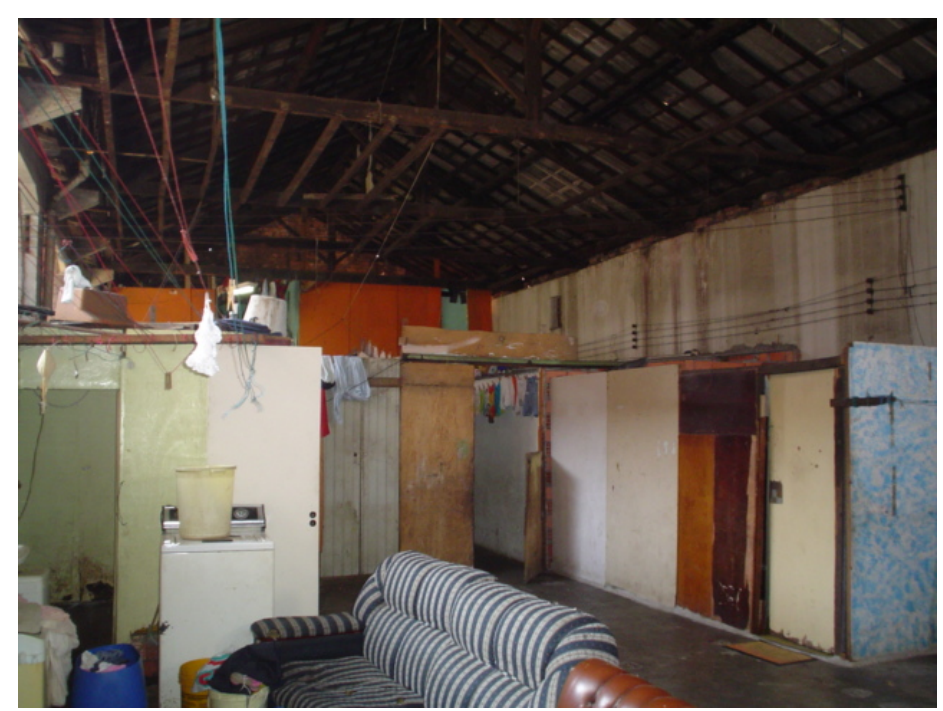

Foto 113 - Rua Martim Afonso, 83. 


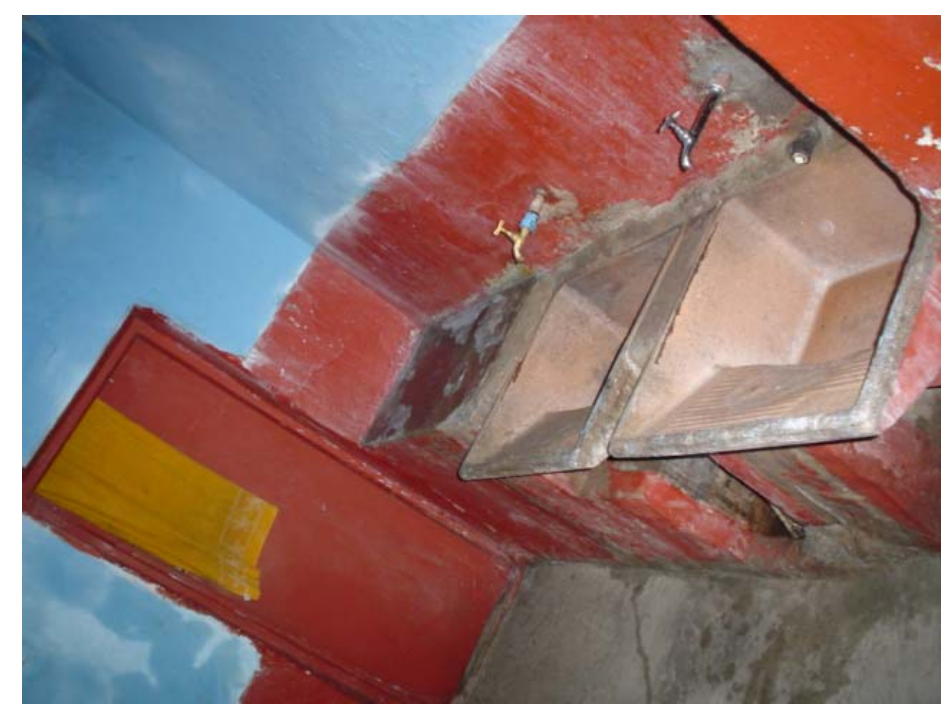

Foto 114 - Rua João Teodoro, 919.

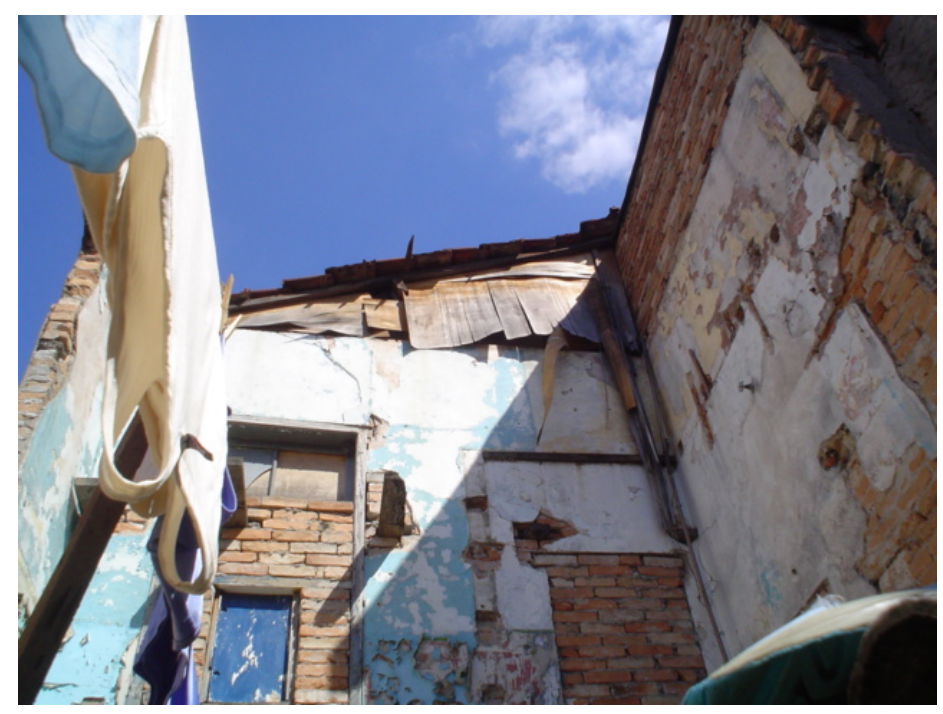

Foto 115 - Rua João Teodoro, 909.

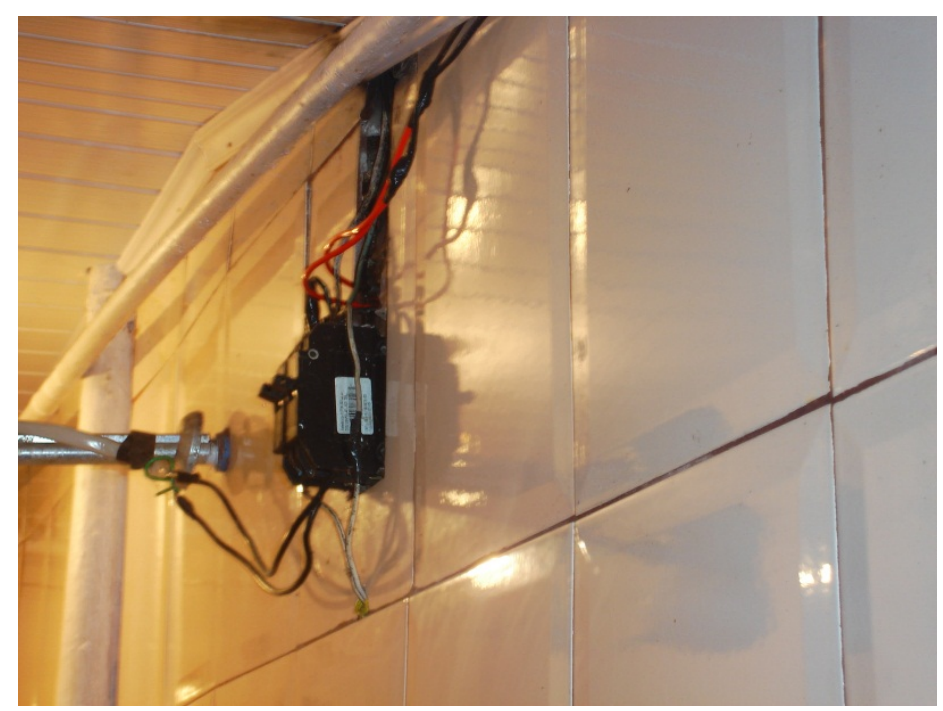

Foto 116 - Rua Rui Barbosa, 549. 
ANEXO H - Fotografias do Livro Cortiços: A experiência de São Paulo.

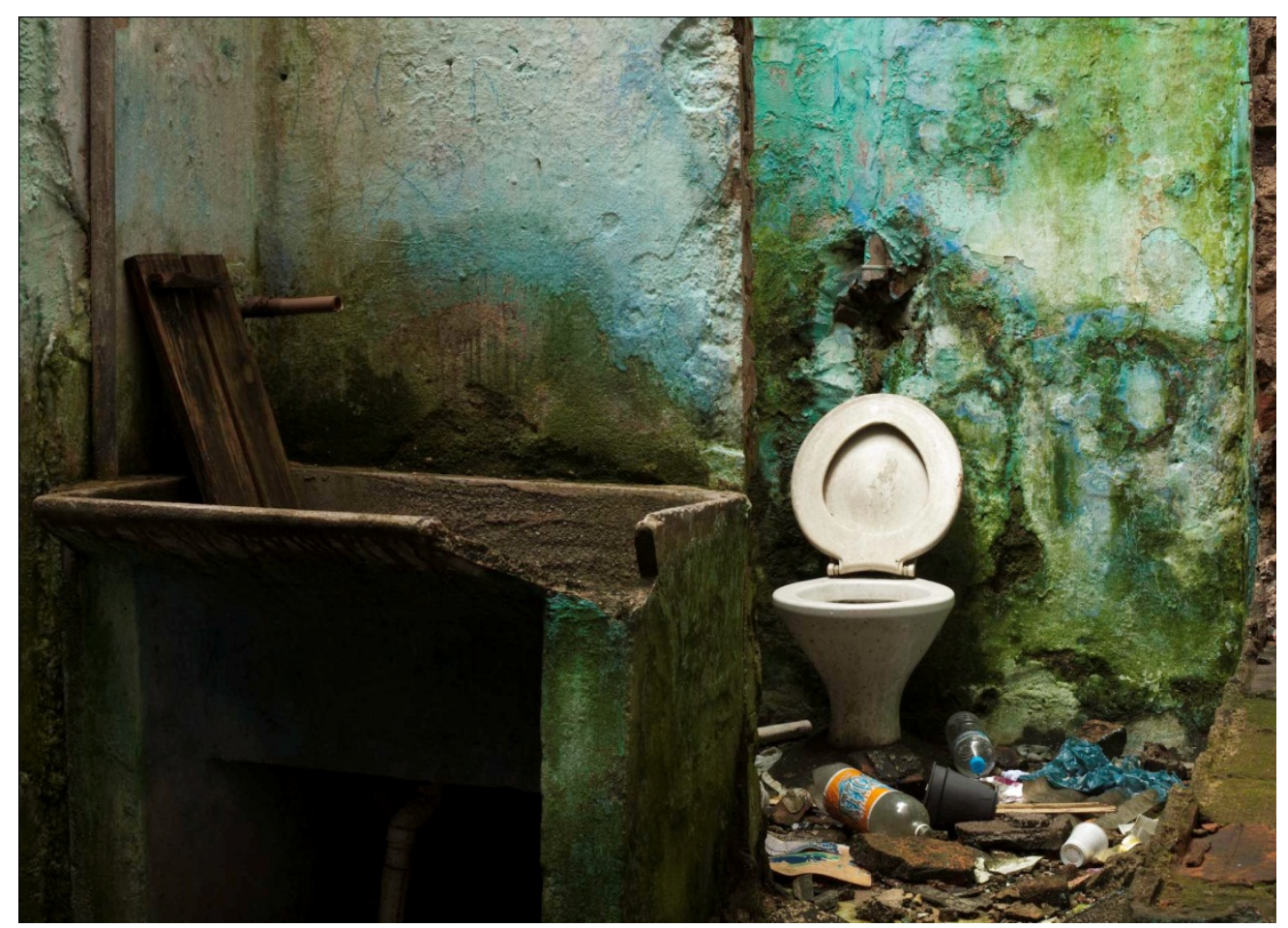

Foto 117 - Rua Asdrúbal do Nascimento, 284.

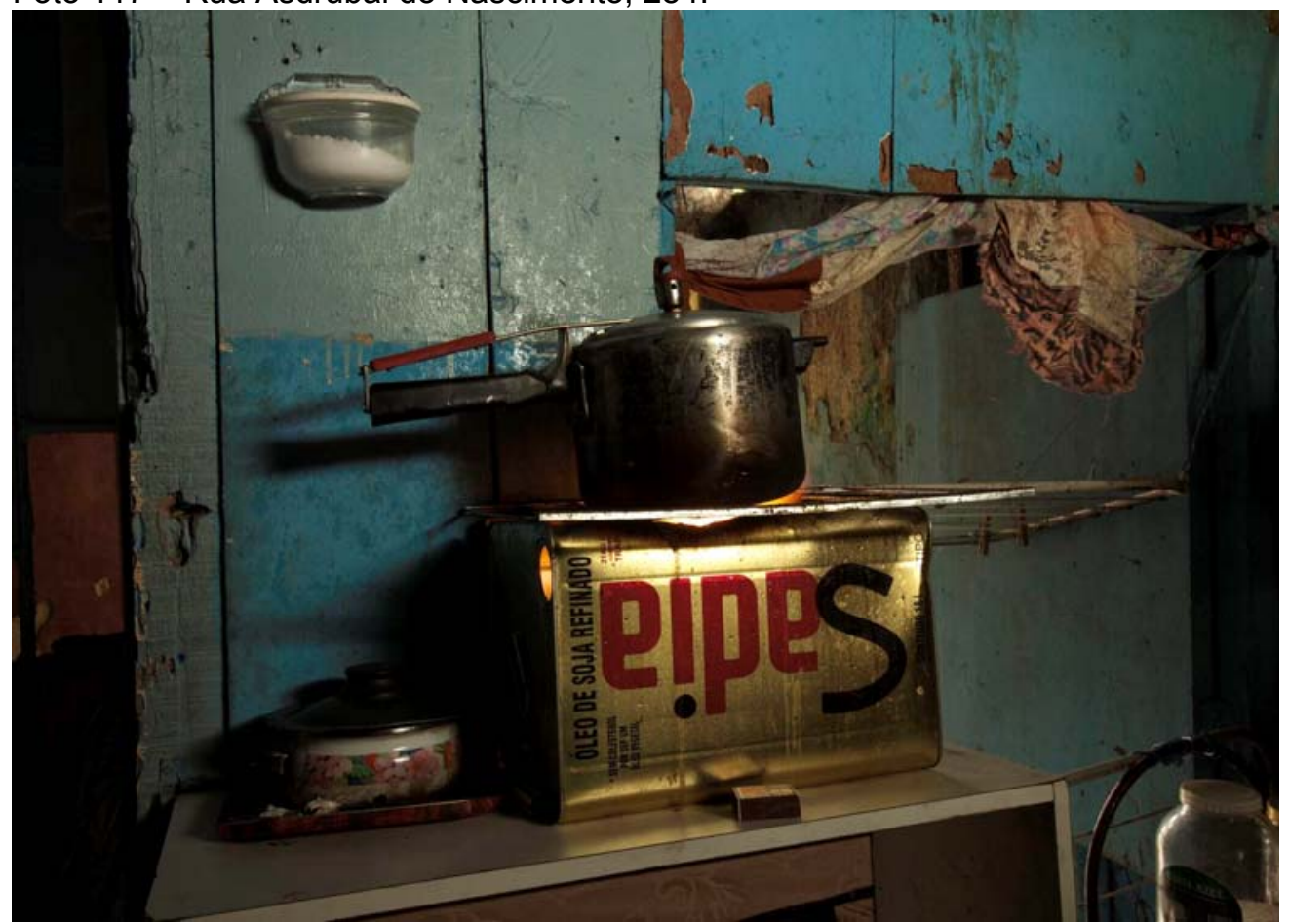

Foto 118 - Rua Asdrúbal do Nascimento, 284. 


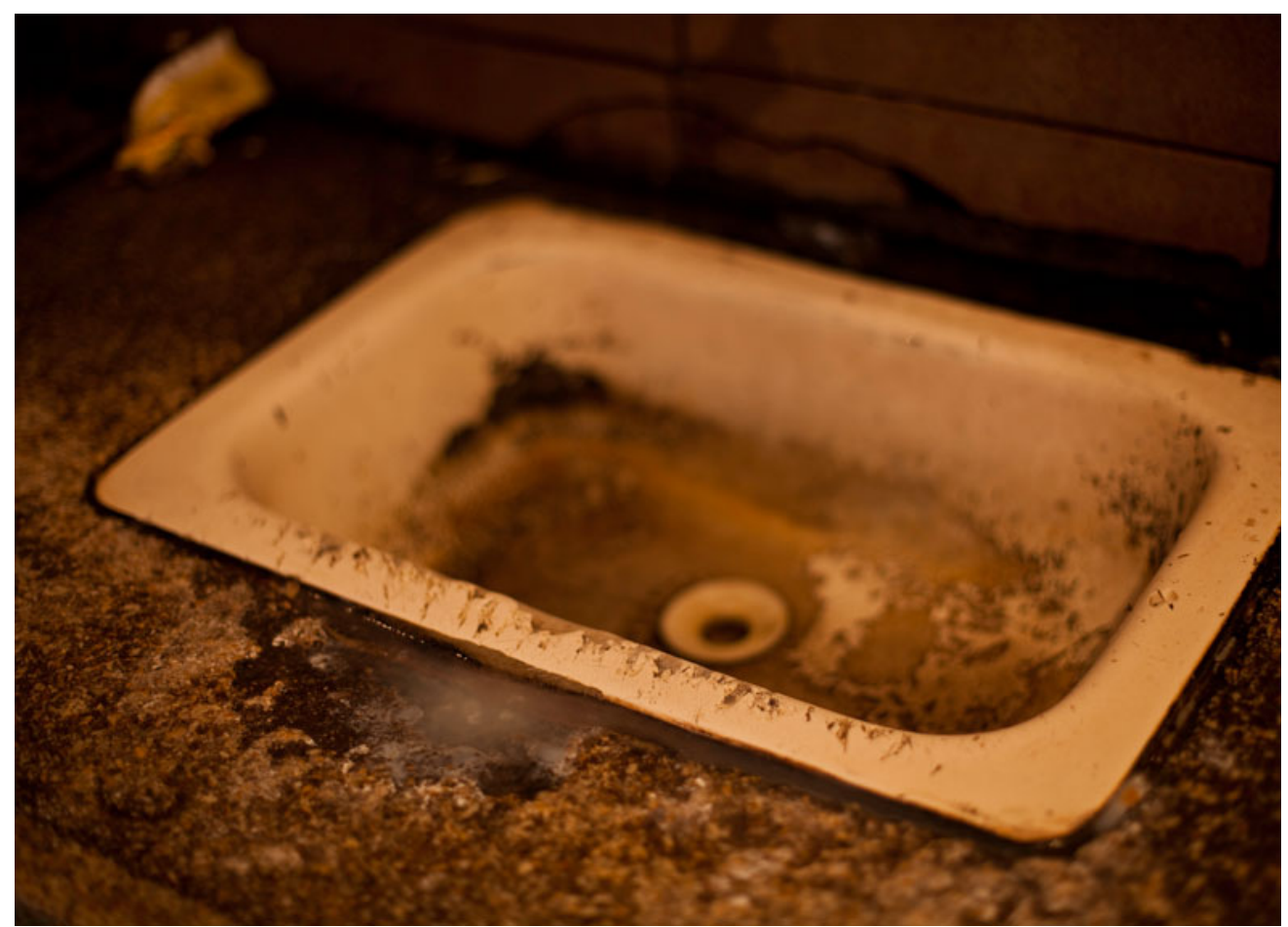

Foto 119 - Rua João Jacinto, 54.

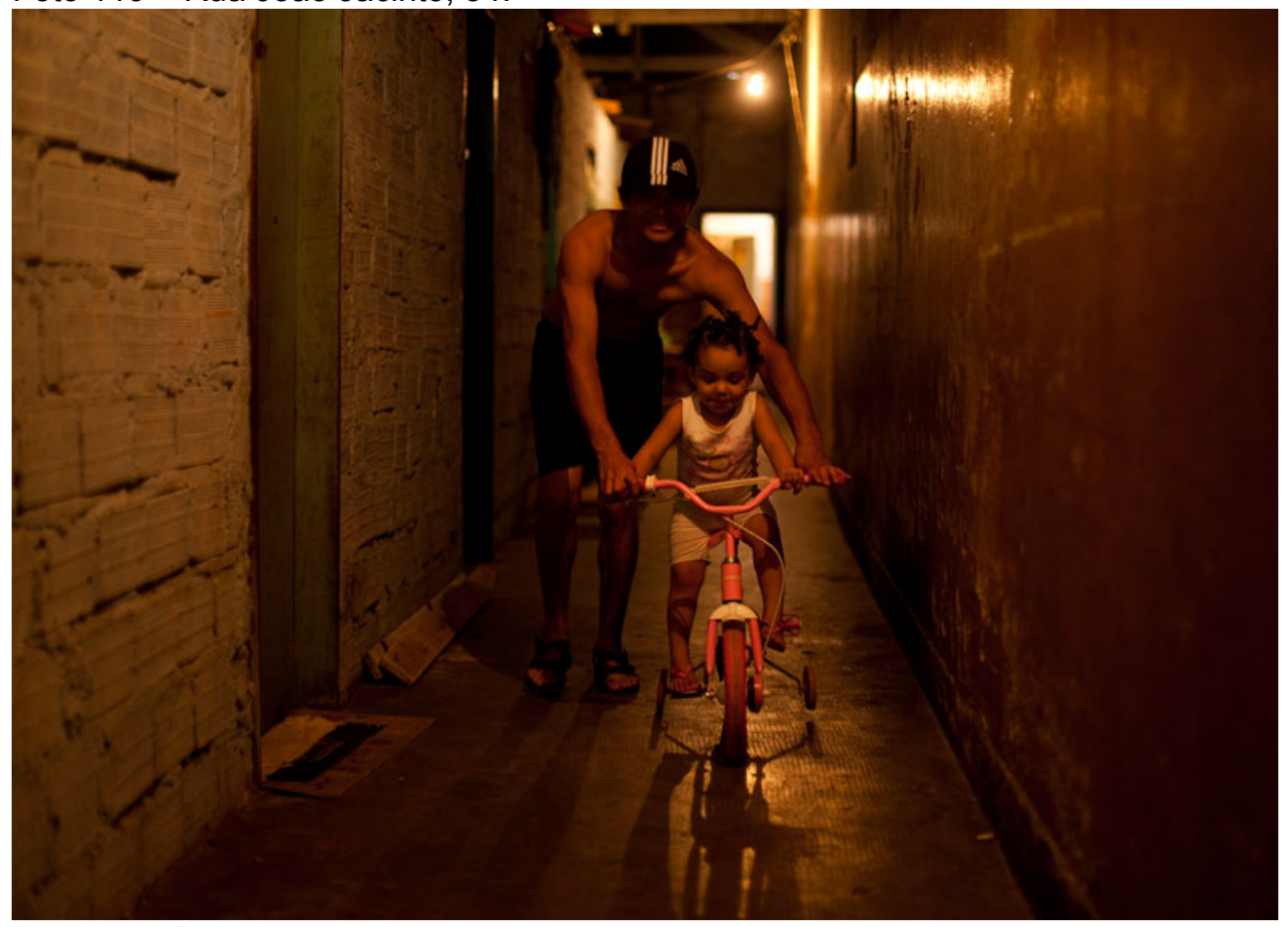

Foto 120- Rua João Jacinto, 54. 


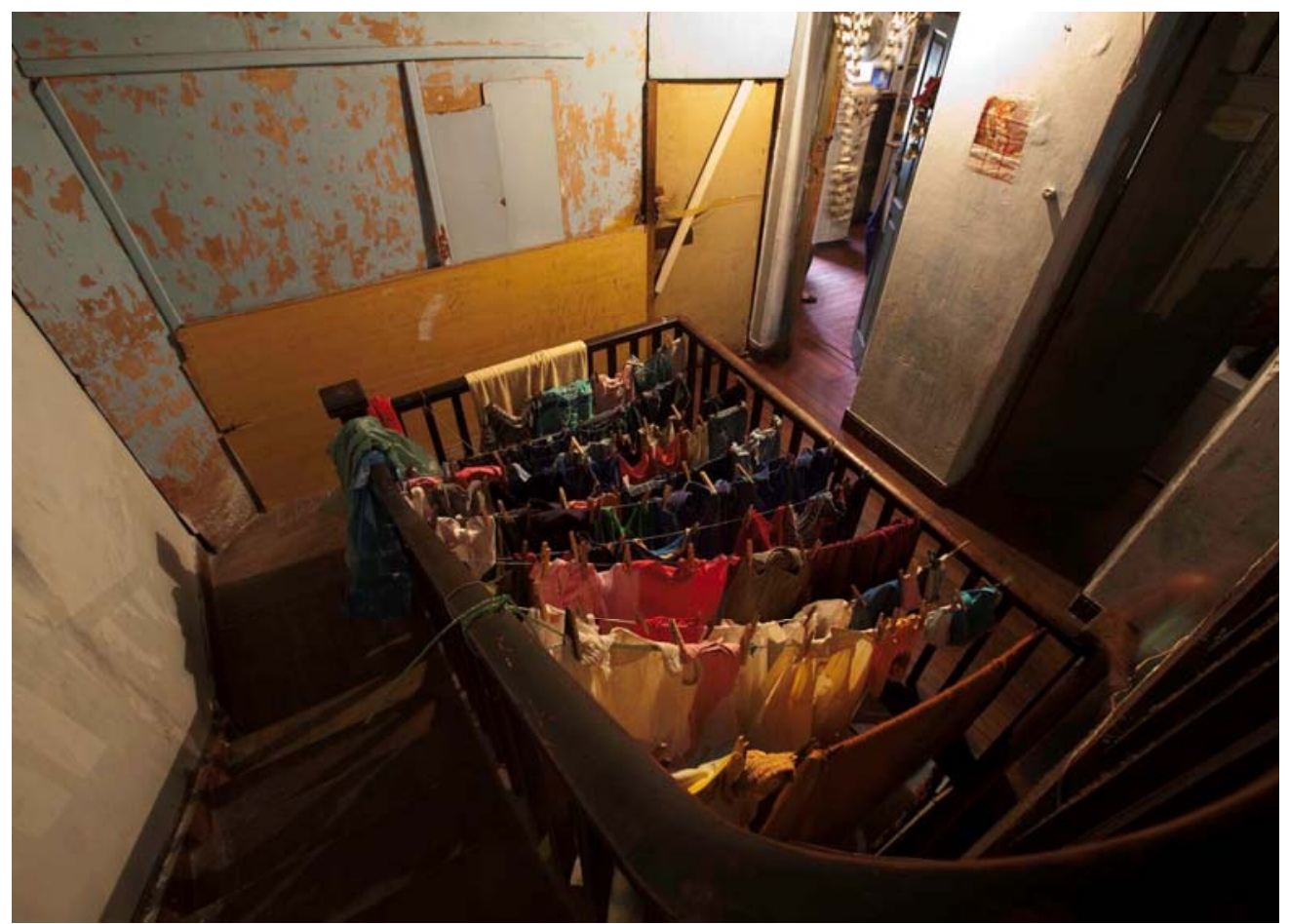

\section{Foto 121 - Rua Eloi Cerqueira, 237.}

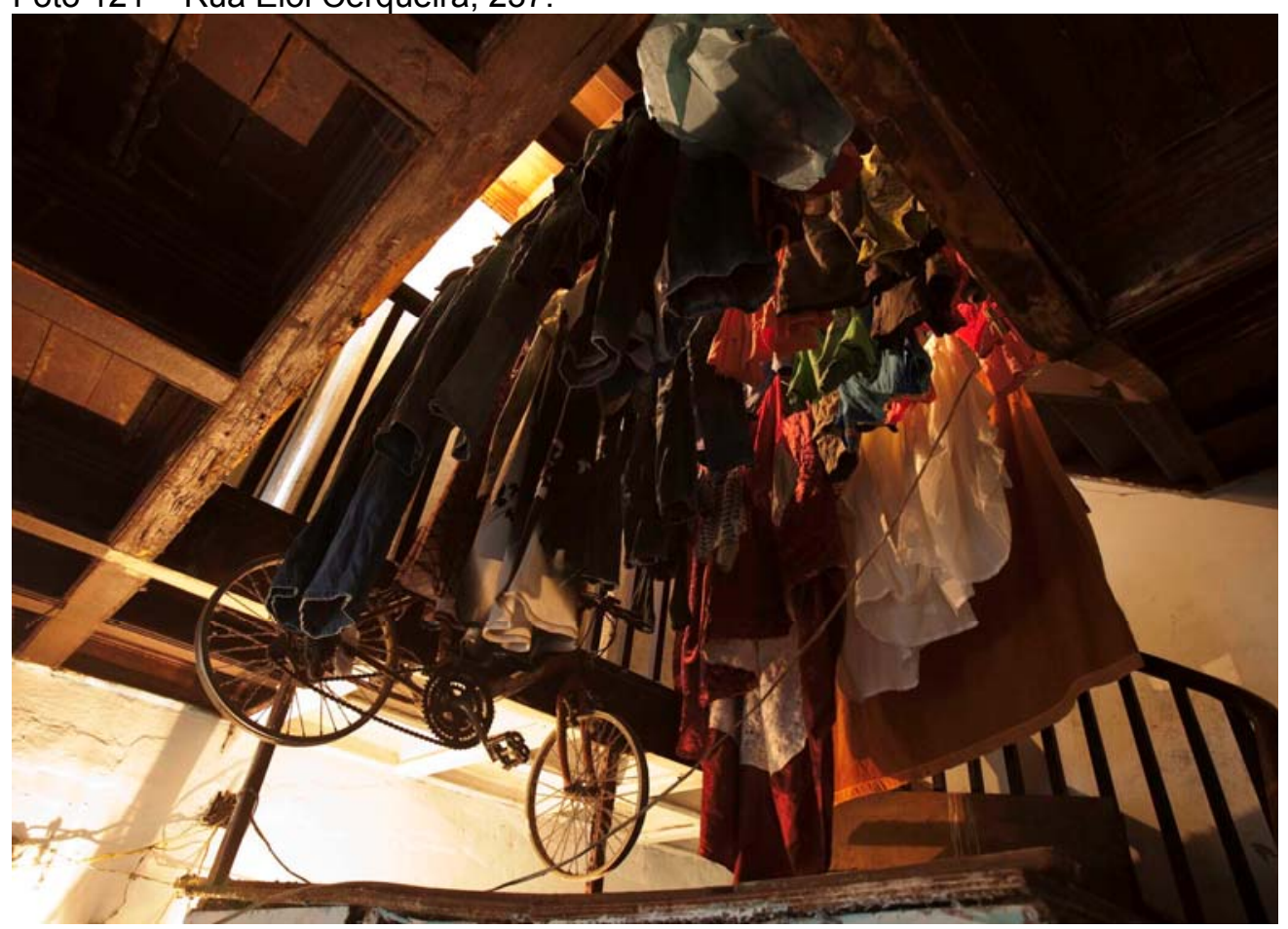

Foto 122 - Rua Eloi Cerqueira, 237. 


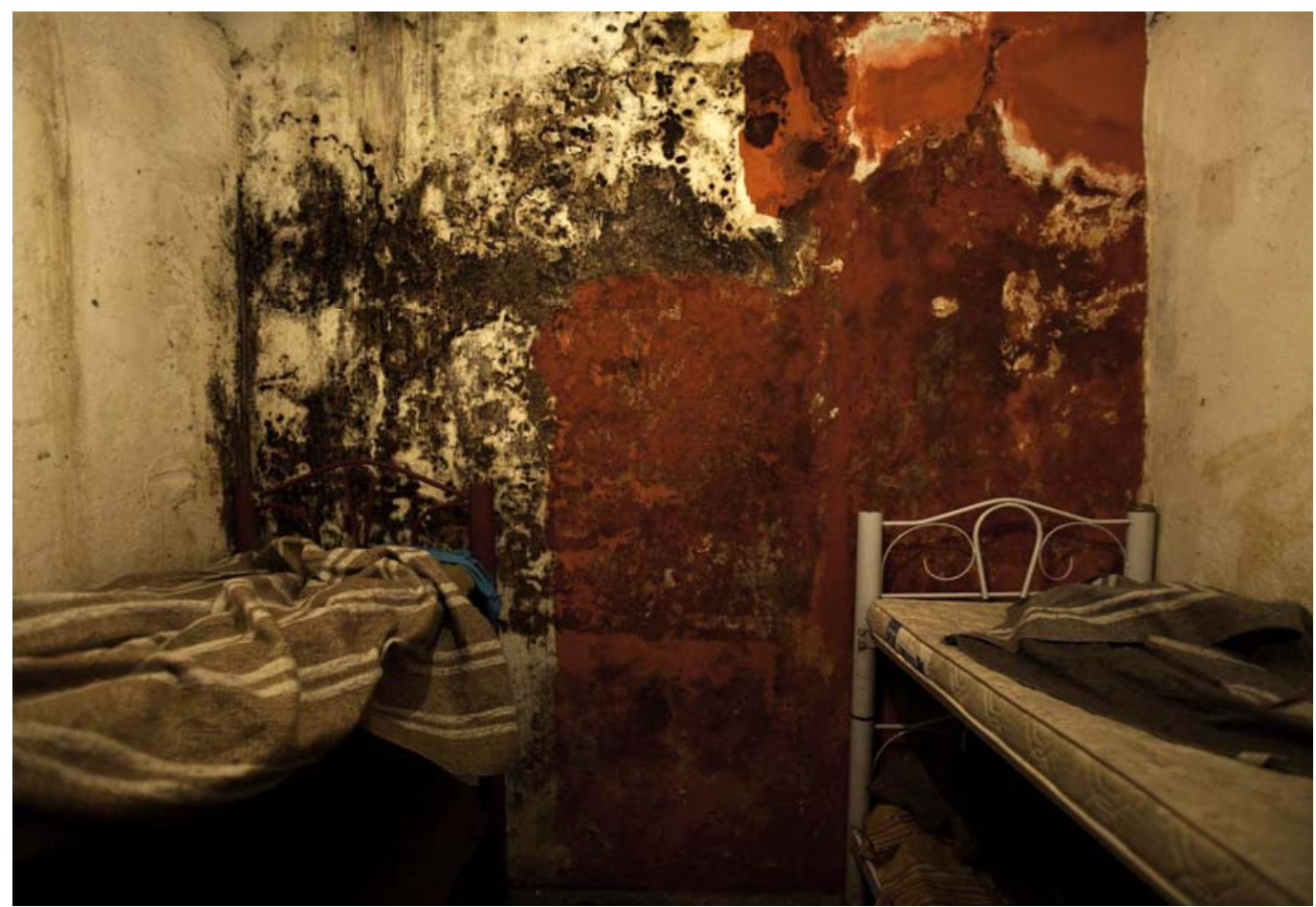

Foto 123 - Rua Dino Bueno, 108.

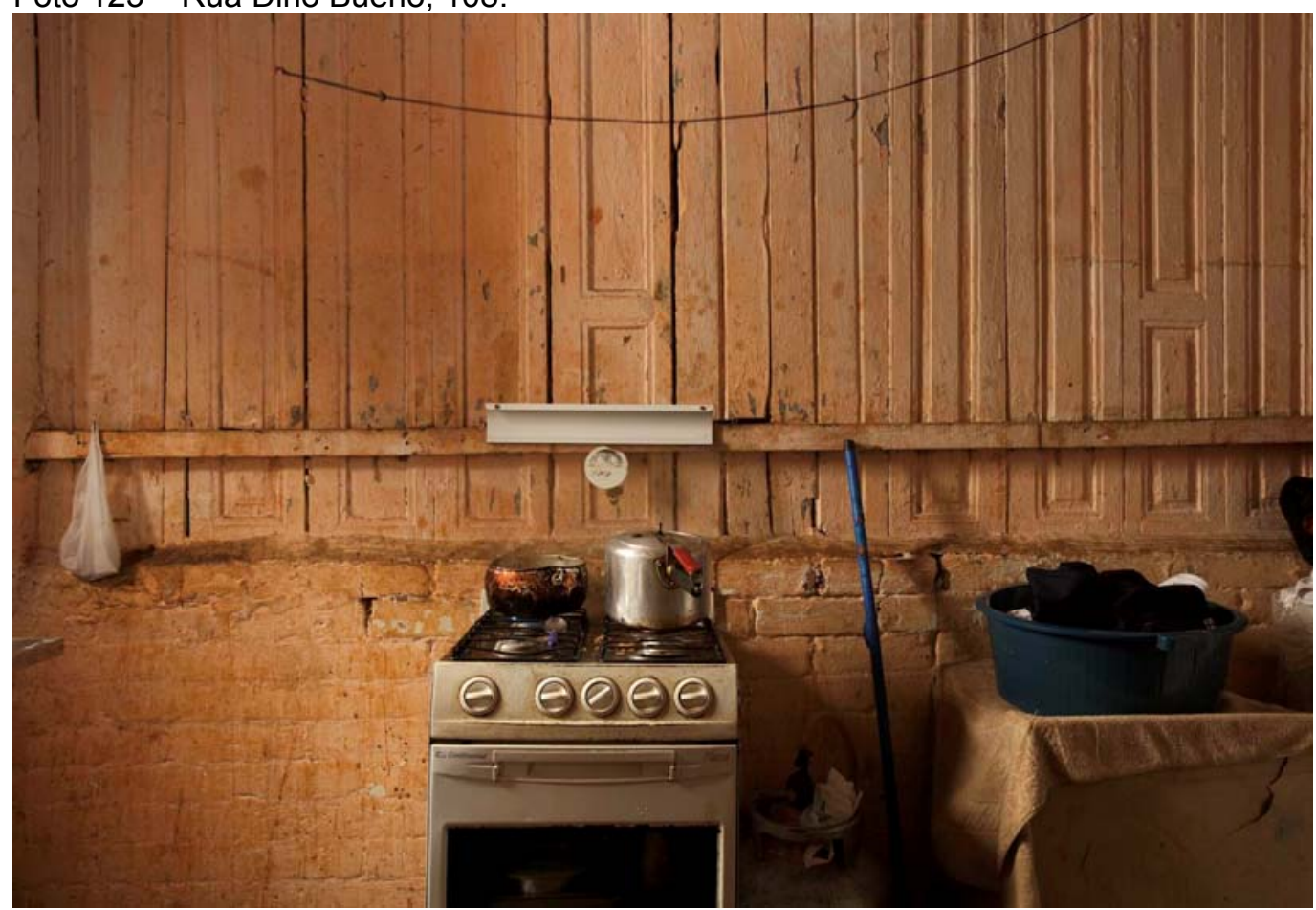

Foto 124 - Rua São Paulo, 141. 


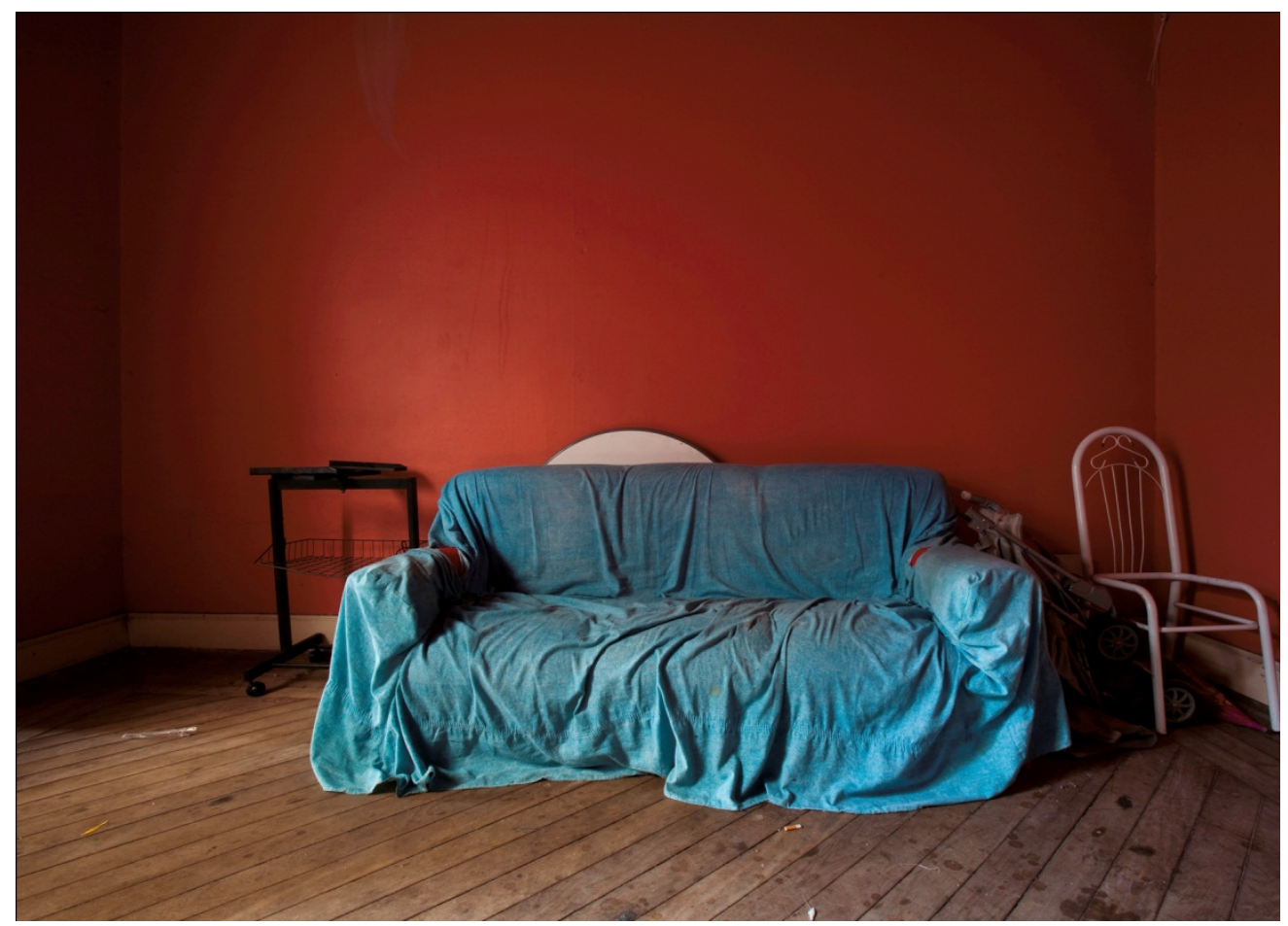

Foto 125 - Rua do Glicério, 745.

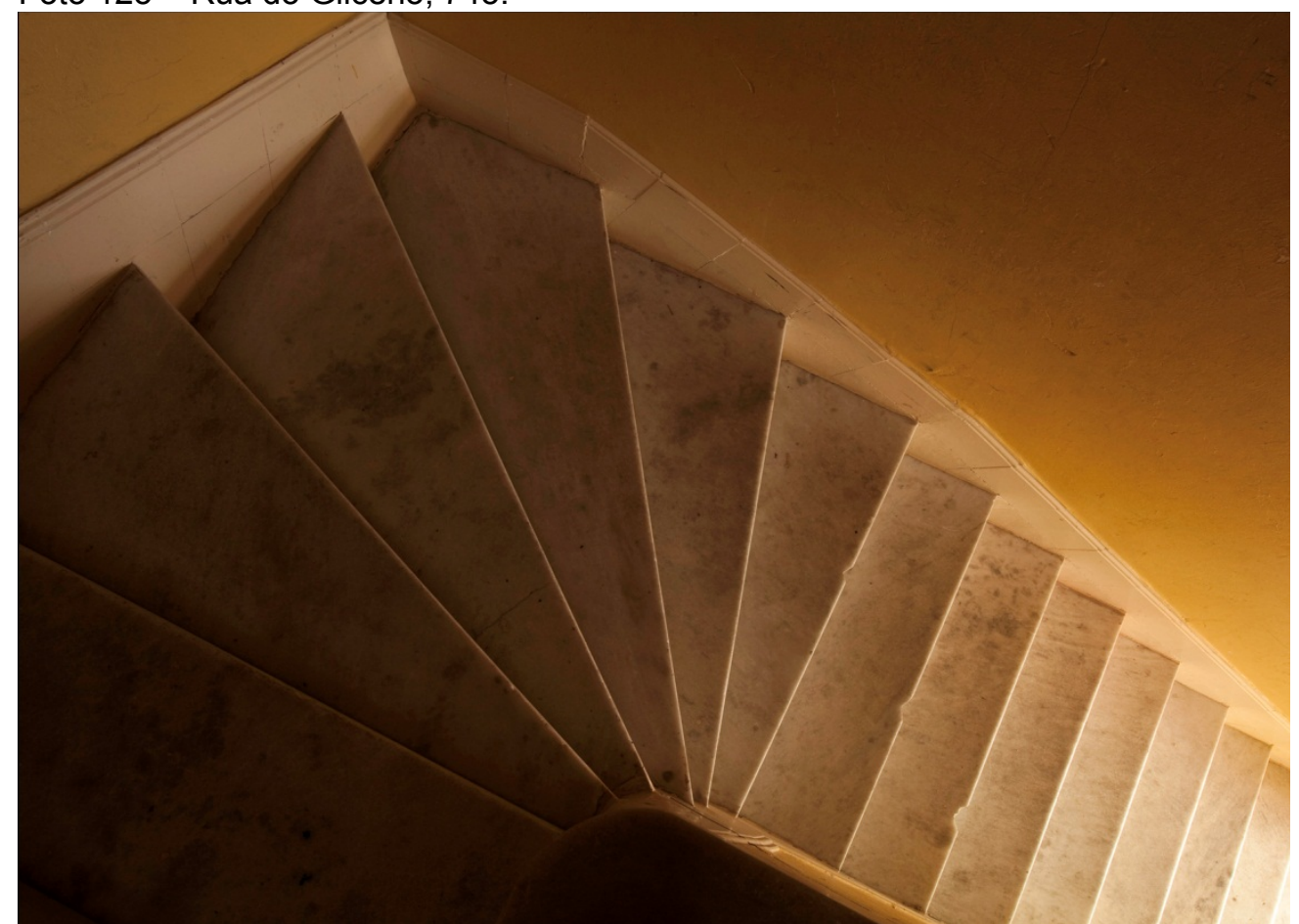

Foto 126 - Rua do Glicério, 745. 


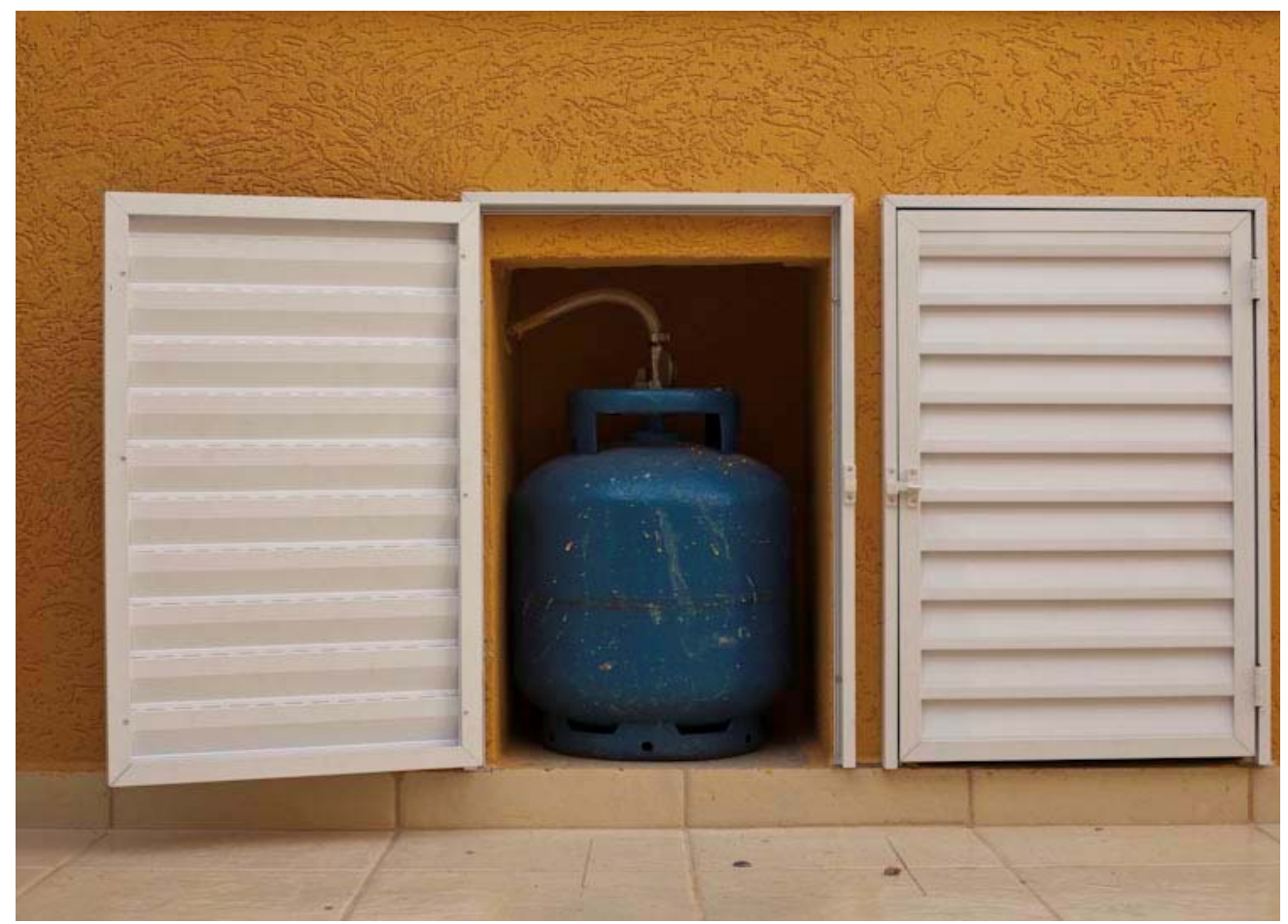

Foto 127 - Rua Piratininga, 879.

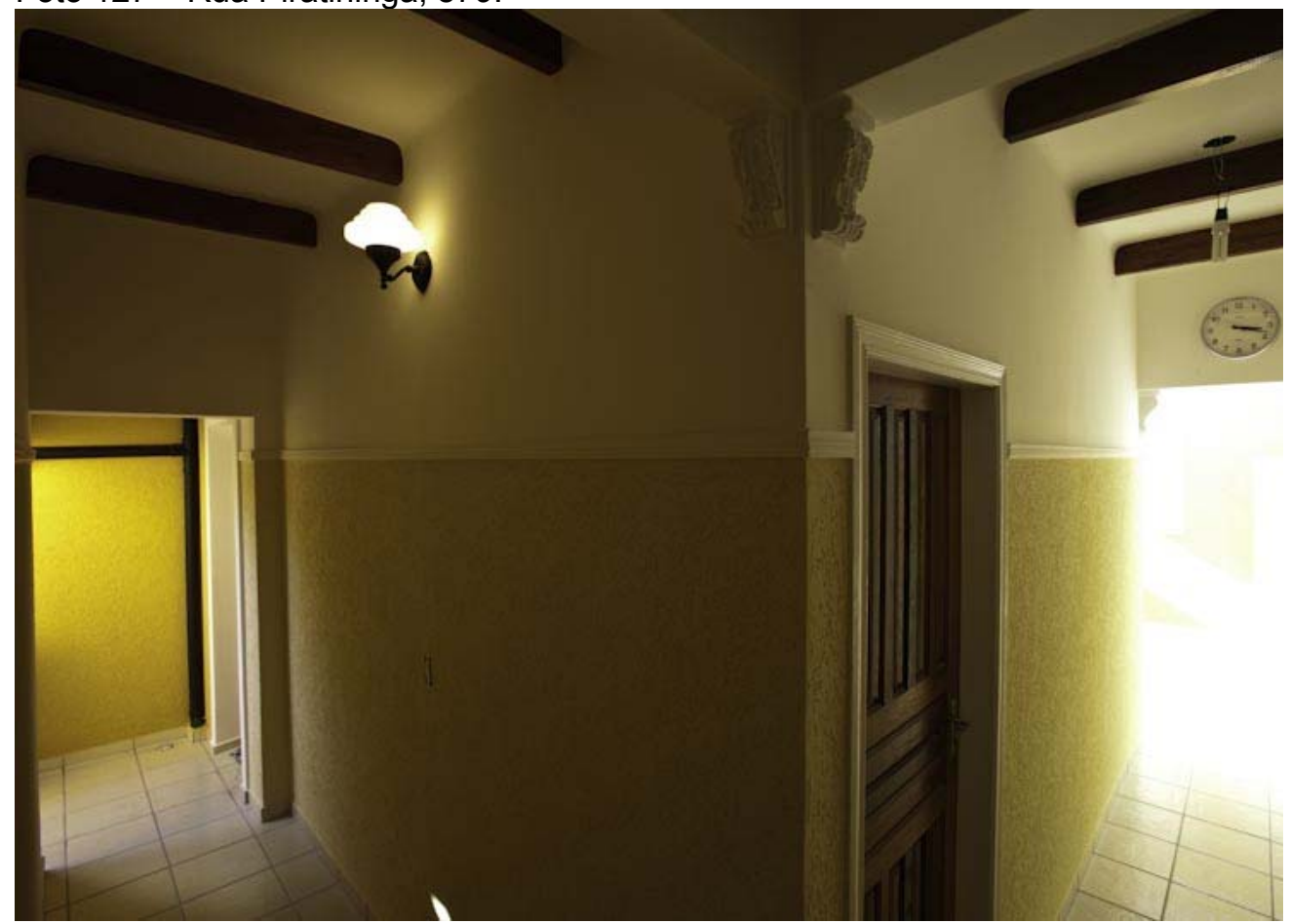

Foto 128 - Rua Piratininga, 879. 


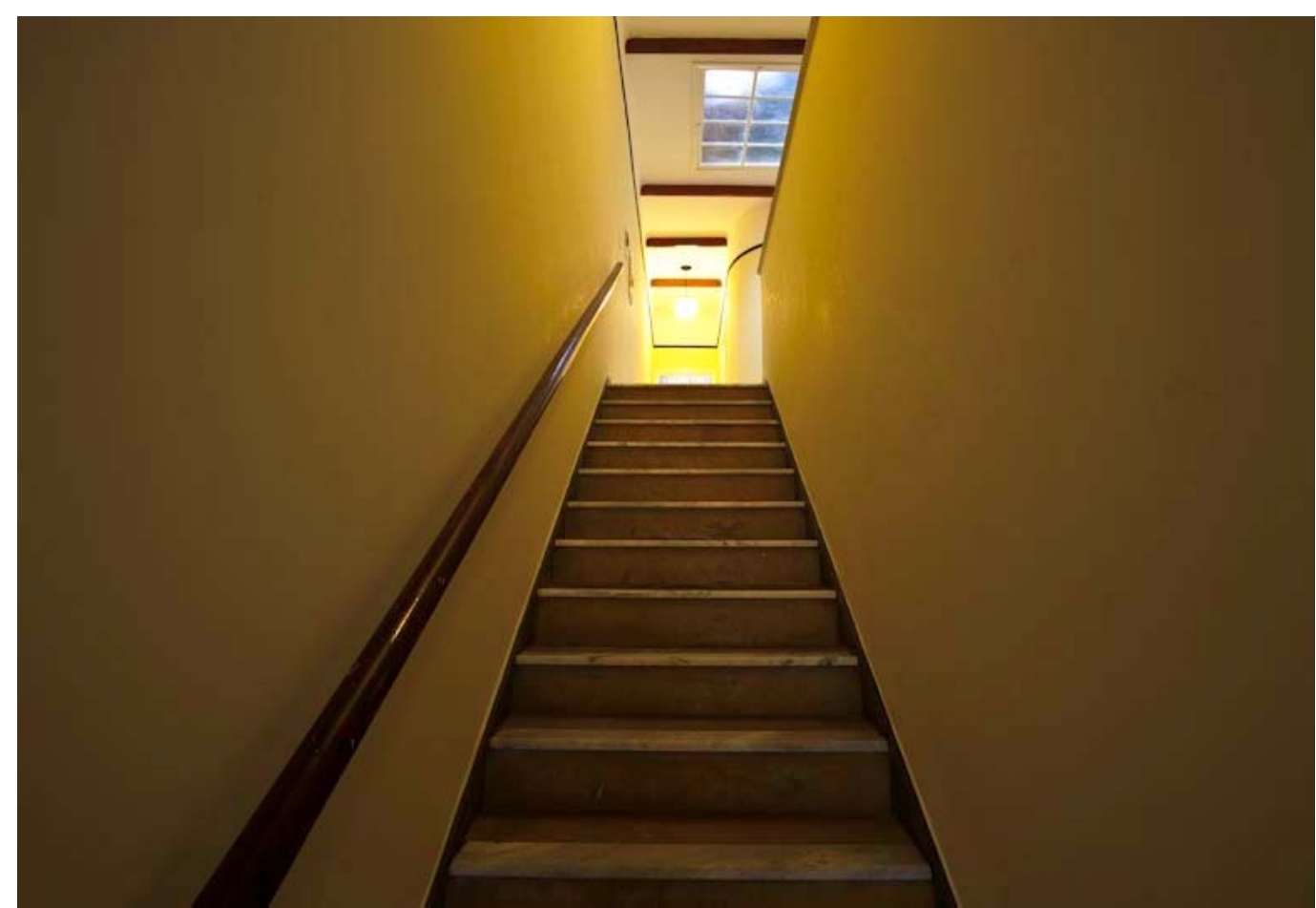

Foto 129 - Rua Piratininga, 879.

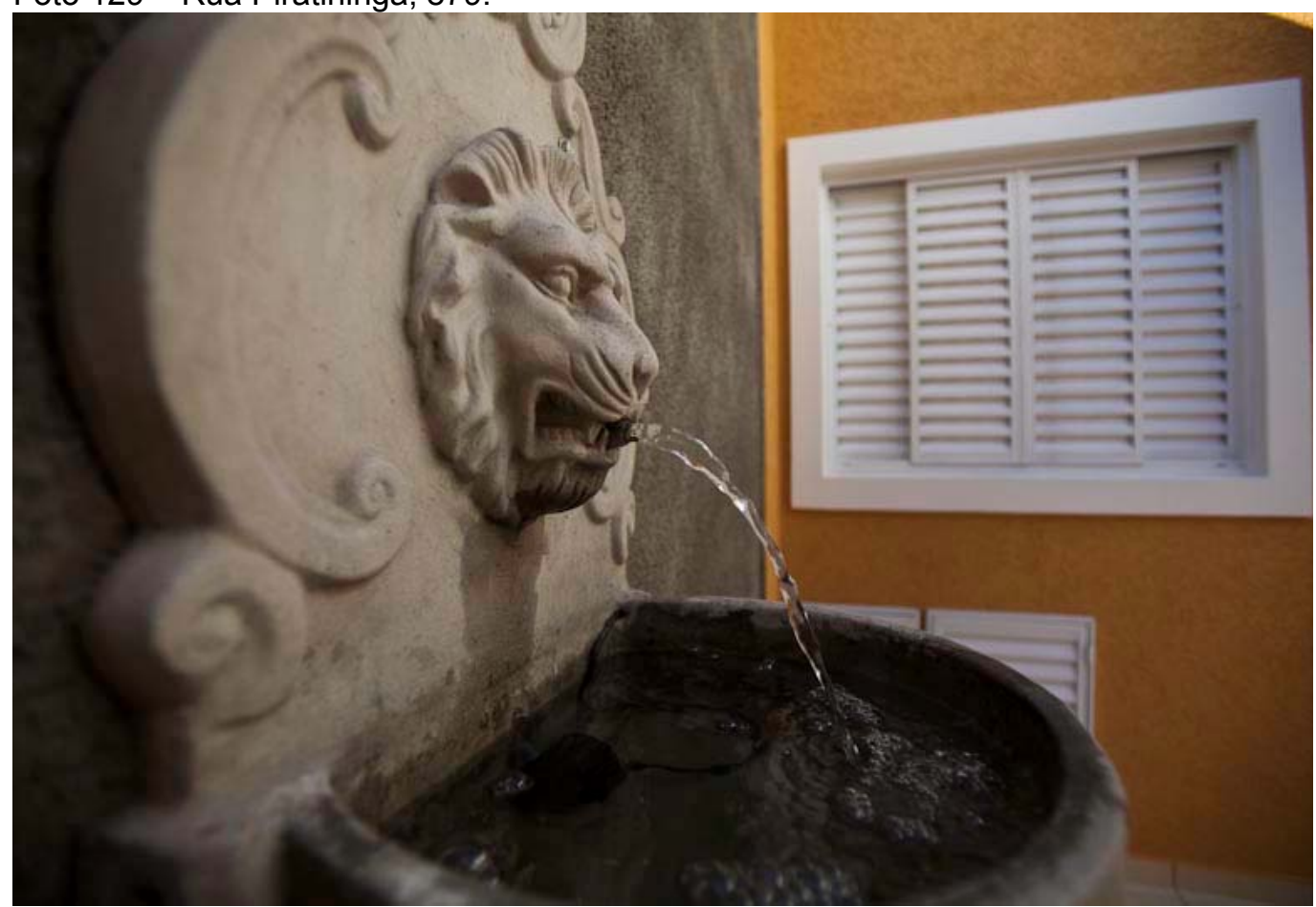

Foto 130 - Rua Piratininga, 879. 